\title{
Dietary factors modulating postprandial protein handling
}

Citation for published version (APA):

Gorissen, S. H. M. (2016). Dietary factors modulating postprandial protein handling. [Doctoral Thesis, Maastricht University]. Datawyse / Universitaire Pers Maastricht. https://doi.org/10.26481/dis.20160623sg

Document status and date:

Published: 01/01/2016

DOI:

$10.26481 /$ dis.20160623sg

Document Version:

Publisher's PDF, also known as Version of record

\section{Please check the document version of this publication:}

- A submitted manuscript is the version of the article upon submission and before peer-review. There can be important differences between the submitted version and the official published version of record.

People interested in the research are advised to contact the author for the final version of the publication, or visit the DOI to the publisher's website.

- The final author version and the galley proof are versions of the publication after peer review.

- The final published version features the final layout of the paper including the volume, issue and page numbers.

Link to publication

\footnotetext{
General rights rights.

- You may freely distribute the URL identifying the publication in the public portal. please follow below link for the End User Agreement:

www.umlib.nl/taverne-license

Take down policy

If you believe that this document breaches copyright please contact us at:

repository@maastrichtuniversity.nl

providing details and we will investigate your claim.
}

Copyright and moral rights for the publications made accessible in the public portal are retained by the authors and/or other copyright owners and it is a condition of accessing publications that users recognise and abide by the legal requirements associated with these

- Users may download and print one copy of any publication from the public portal for the purpose of private study or research.

- You may not further distribute the material or use it for any profit-making activity or commercial gain

If the publication is distributed under the terms of Article $25 \mathrm{fa}$ of the Dutch Copyright Act, indicated by the "Taverne" license above, 


\section{CIRCHLATION \\ CASETI}

\section{Dietary factors modulating $\because$ postprandial protein handling \\ Stefan Gorissen}

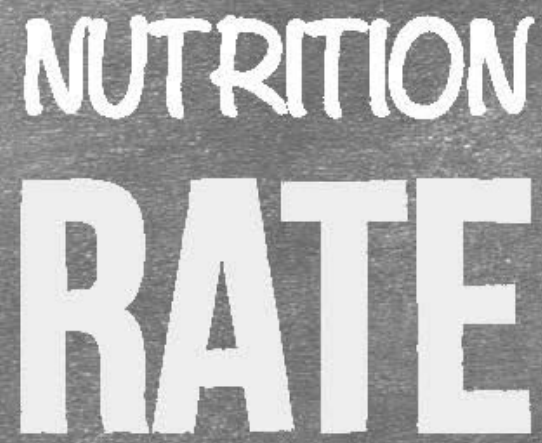

POSTRETIL

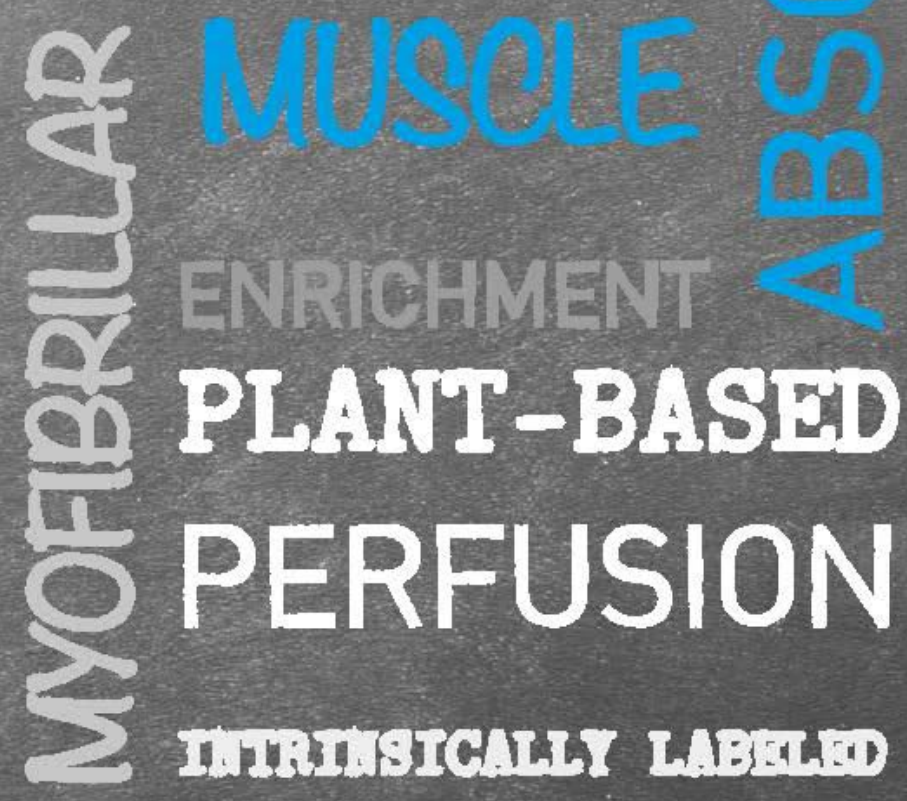

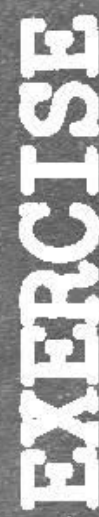

1

$\frac{1}{2}$

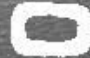

A
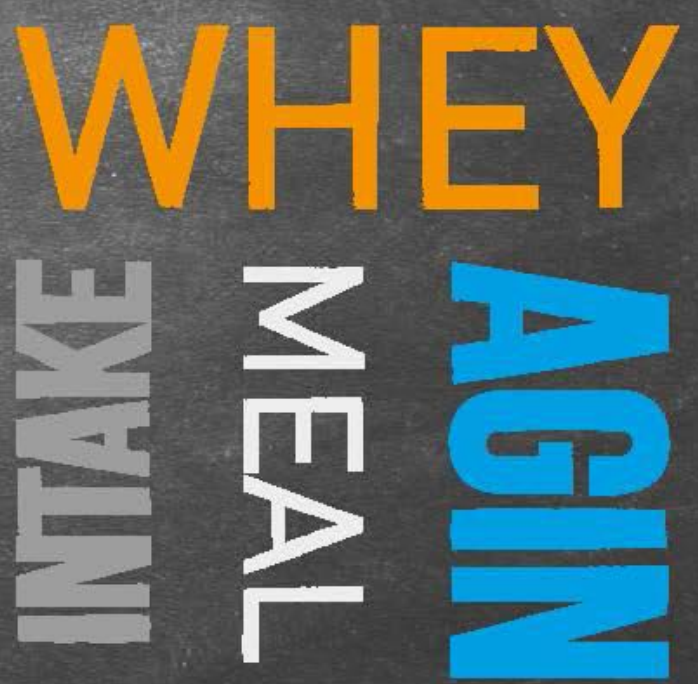

SAELETal 

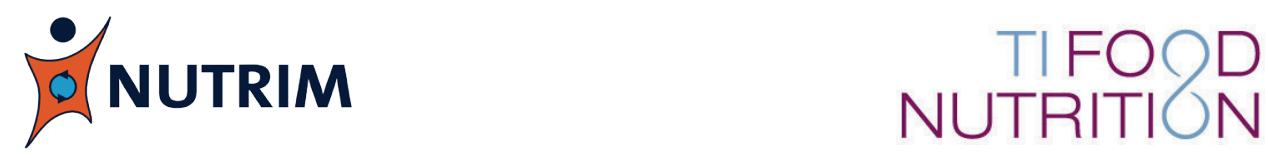

The work presented in this dissertation was performed within NUTRIM School of Nutrition and Translational Research in Metabolism, accredited by the Royal Netherlands Academy of Arts and Sciences, and within the framework of TI Food and Nutrition.

Cover design \& layout: Amazed-desing.nl - Shannen Duyzings

Printed by: Datawyse, Universitaire Pers Maastricht

ISBN 9789461595652

\section{Copyright $\odot 2016$ Stefan Gorissen}

All rights reserved. No part of this dissertation may be reproduced, distributed, or transmitted in any form or by any means, including photocopying, recording, or other electronic or mechanical methods, without the prior written permission of the author or publisher, except in the case of brief quotations embodied in critical reviews and certain other noncommercial uses permitted by copyright law. 


\title{
Dietary factors modulating
}

\section{postprandial protein handling}

\author{
PROEFSCHRIFT
}

Ter verkrijging van de graad van doctor aan de Universiteit Maastricht, op gezag van de Rector Magnificus, Prof. dr. L.L.G. Soete volgens het besluit van het College van Decanen,

in het openbaar te verdedigen op donderdag 23 juni 2016 om 12.00 uur

door

Stefan Hubertus Maria Gorissen 


\section{Promotor}

Prof. dr. L.J.C. van Loon

\section{Copromotor}

Dr. N.A. Burd (University of Illinois, Verenigde Staten)

\section{Beoordelingscommissie}

Prof. dr. E.E. Blaak (voorzitter)

Prof. dr. Y. Boirie (University Hospital of Clermont-Ferrand, Frankrijk)

Prof. dr. E.J.M. Feskens (Wageningen UR)

Dr. K. Lenaerts

Prof. dr. S.W.M. Olde Damink 


\section{Table of contents}

$\begin{array}{lll}\text { Chapter } 1 \text { General introduction } & 7\end{array}$

Chapter 2 Carbohydrate co-ingestion delays dietary protein digestion and absorption but does not modulate postprandial muscle protein accretion

Chapter 3 Co-ingesting milk fat with micellar casein does not affect postprandial protein handling in healthy older men

Chapter 4 Differences in postprandial protein handling after beef versus milk ingestion during post-exercise recovery: a randomized controlled trial

Chapter 5 The anabolic properties of wheat protein (hydrolysate) compared to casein and whey protein: a randomized trial

Chapter 6 Habituation to a low or high protein intake does not modulate basal or postprandial muscle protein synthesis rates: a randomized trial

Chapter 7 General discussion

Addendum Summary

Samenvatting

Valorization

Dankwoord

Curriculum Vitae

Financial support 


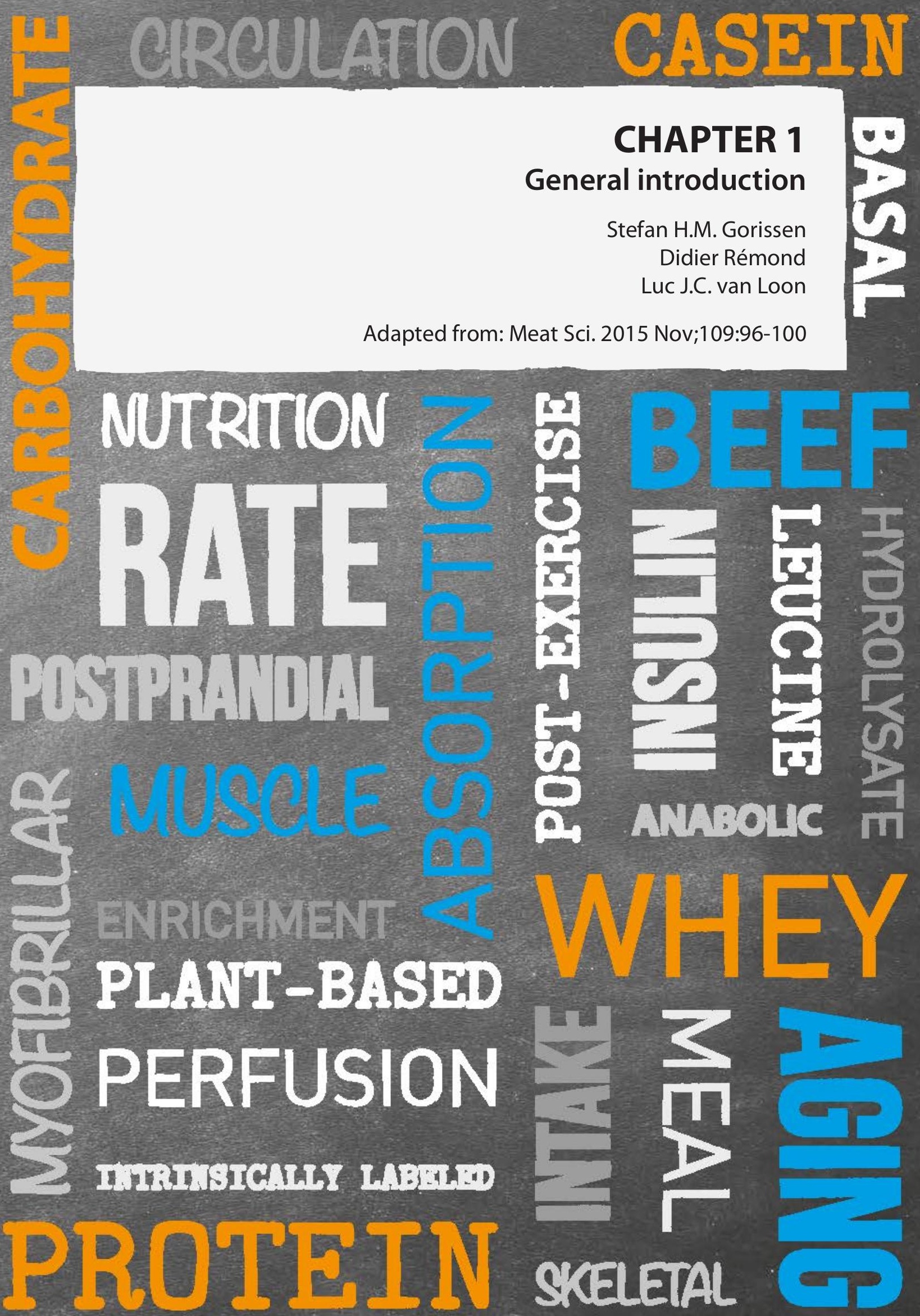




\section{SARCOPENIA}

Between 2015 and 2050, the proportion of the world's population over 60 years will nearly double from approximately 12 to $22 \%$ (1). The number of people aged 80 years or older will almost quadruple between 2015 and 2050 to 434 million (1). This increasing elderly population can be seen as a success for public health policies, but also has major implications for healthcare costs and quality of life of elderly people (1). Aging is accompanied by changes in body composition, i.e. an increase in fat mass and a decline in skeletal muscle mass. Loss of skeletal muscle mass may lead to a reduction in physical function or muscle weakness, which increases the risk of falls and fractures. This could ultimately result in loss of independence and increasing nursing home admissions. The age-related loss of skeletal muscle mass and function has been called sarcopenia (sarx in Greek is flesh and penia is loss) (2). Though sarcopenia is a process of normal aging, muscle mass is amenable to intervention. Developing effective interventions to prevent or delay the onset of sarcopenia may reduce healthcare costs and improve the quality of life of older individuals.

\section{REGULATION OF SKELETAL MUSCLE MASS}

Muscle mass maintenance is achieved through counterbalanced fluctuations in muscle protein synthesis and breakdown rates such that net muscle protein balance remains zero by the end of each day (3). Aging, muscle disuse, and chronic metabolic diseases are characterized by a decline in skeletal muscle mass. This decline in muscle mass must be attributed to an imbalance between protein breakdown and synthesis rates, resulting in a negative net muscle protein balance. Since basal muscle protein synthesis rates do not seem to differ between healthy young and older men (4), researchers have been assessing whether derangements in the muscle protein synthetic response to the main anabolic stimuli, physical activity and food intake, underpin the loss of skeletal muscle mass with advancing age. Several studies have shown that muscle protein synthesis rates are not increased to the same extent in older when compared with young individuals following ingestion of amino acids (5-7). This phenomenon has been referred to as 'anabolic resistance' $(8,9)$. Optimizing food intake to allow for maximal stimulation of postprandial muscle protein synthesis rates may attenuate the loss of skeletal muscle mass as observed in various clinical settings.

\section{POSTPRANDIAL MUSCLE PROTEIN SYNTHESIS}

Food intake, and protein ingestion in particular, has been shown to stimulate muscle protein synthesis rates. The postprandial muscle protein synthetic response to protein ingestion is regulated on a number of levels (Figure 1.1) (8). Protein digestion and amino acid absorption kinetics have a major impact on the postprandial anabolic response. Rapidly digestible proteins (such as whey protein) may stimulate protein synthesis to a greater extent for a shorter time period, whereas slowly digestible proteins (such as casein) may stimulate protein synthesis to a more moderate extent for a longer time period (10). Modulating protein digestion and amino acid absorption kinetics by ingesting whey protein in repeated small boluses (simulating digestion and absorption kinetics of a slowly digestible protein) or by ingesting hydrolyzed casein (rapidly digestible) affects the postprandial muscle protein synthetic response (11-14). Moreover, splanchnic retention of dietary protein-derived amino acids (which includes amino acid uptake by gut and liver tissue) may modulate postprandial muscle protein synthesis by affecting the postprandial availability of circulating amino acids $(15,16)$. Furthermore, the postprandial rise in insulin concentrations can modulate the muscle protein synthetic response through its 
vasodilatory properties, i.e. stimulating endothelial nitric oxide synthase (eNOS), resulting in greater capillary recruitment, increased microvascular volume and nutritive blood flow to skeletal muscle tissue $(17,18)$. It could be speculated that the postprandial increase in muscle tissue perfusion will increase intramuscular availability of nutrients and growth factors and, as such, stimulate muscle protein synthesis rates. The stimulation of muscle protein synthesis has been shown to be blunted in insulin resistant subjects under hyperinsulinemic-euglycemic conditions $(19,20)$, further emphasizing the proposed role of insulin in the postprandial stimulation of muscle protein synthesis. Finally, the postprandial increase in muscle protein synthesis may also be regulated through amino acid uptake by amino acid transporters located on the cell membrane of muscle cells (21) and subsequent activation of intramyocellular mTORC1 signaling towards protein synthesis $(5,22)$. One or more of these processes may be compromised in conditions that are characterized by skeletal muscle loss such as aging, disuse, or chronic metabolic diseases. Several protein (intake) characteristics may influence the postprandial muscle protein synthetic response and may need consideration when trying to develop more effective dietary strategies to prevent or attenuate the loss of skeletal muscle mass. 


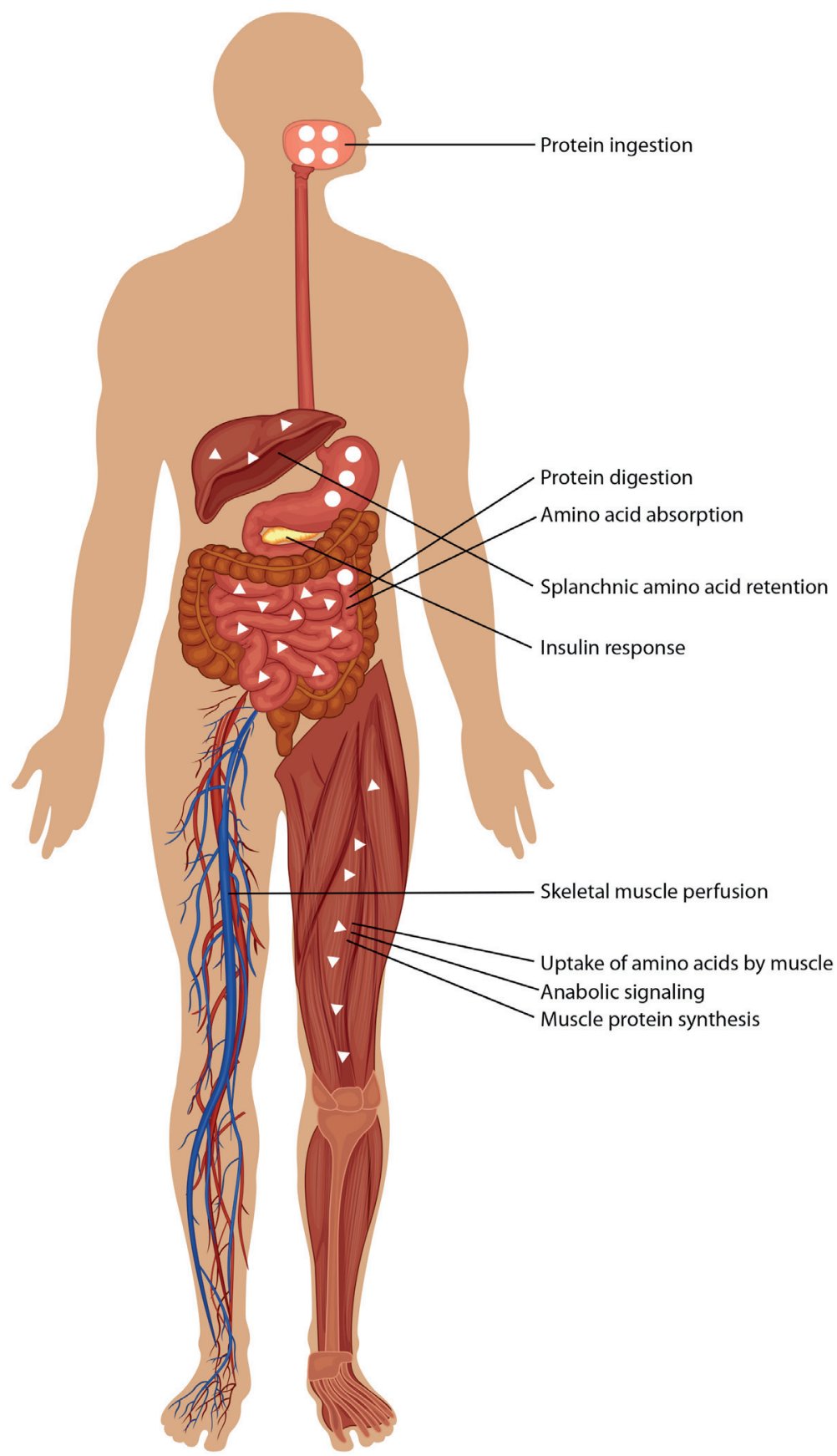

Figure 1.1 | Schematic representation of the regulation of the postprandial muscle protein synthetic response to protein ingestion. 


\section{PROTEIN SOURCE}

Various studies have reported improved net protein balance and/or increased muscle protein synthesis rates following the ingestion of isolated protein sources such as whey protein (23), casein (24), casein hydrolysate $(12,13)$, soy $(25-27)$, and egg protein (28). Even though all of these protein sources have the capacity to stimulate muscle protein anabolism, postprandial muscle protein synthesis rates can vary substantially following the ingestion of these different protein sources. The question that arises from this work: what characteristics of the dietary protein source may influence the postprandial muscle protein synthetic response? It has previously been suggested that the consumption of more rapidly digestible proteins results in a greater stimulation of postprandial muscle protein synthesis when compared with slowly digestible proteins. The concept of fast and slow dietary proteins has been developed by measuring dietary protein digestion and absorption kinetics and subsequent postprandial protein accretion following whey protein compared with casein protein $(10,11)$. However, these proteins differ not only in their digestion and absorption kinetics (29), but also in their amino acid composition. Even when casein was hydrolyzed prior to ingestion it was still unable to stimulate postprandial muscle protein synthesis rates to the same extent as the ingestion of whey protein (13). This suggests that the amino acid composition, and leucine content in particular, represents another key determinant of the postprandial muscle protein synthetic response following protein ingestion. In agreement, addition of free leucine to a bolus of amino acids, protein, or a meal has been shown to further enhance postprandial muscle protein synthesis rates (30-32).

\section{AMOUNT OF PROTEIN}

Though it has been well established that dietary protein effectively stimulates muscle protein synthesis, less information is available on the amount of protein that should be ingested to maximize the postprandial muscle protein synthetic response. It has been shown that graded intakes of essential amino acids (EAA) up to $10 \mathrm{~g}$ (equivalent to $\sim 25 \mathrm{~g}$ of a high quality protein) stimulate myofibrillar protein synthesis rates in a dose-dependent manner (5). However, this response is lower in older individuals, and higher intakes of EAA (20 and $40 \mathrm{~g}$ ) failed to promote a greater muscle protein anabolic response (5). Recently, postprandial muscle protein synthesis rates following the ingestion of increasing amounts of whey protein (i.e., 10, 20, and $40 \mathrm{~g}$ ) have been assessed in both young (33) and older individuals (26). In both age groups, $20 \mathrm{~g}$ of whey protein was required to significantly stimulate muscle protein synthesis rates, and ingesting a higher dose of $40 \mathrm{~g}$ had no additive effect $(26,33)$. However, greater amounts of protein may result in prolonged hyperaminoacidemia (rather than higher peak values) and, as such, stimulate muscle protein synthesis for a more prolonged time period following protein ingestion. Therefore, future dose-response studies should include an assessment of muscle protein synthesis rates over an appropriate postprandial period.

\section{TIMING OF PROTEIN INGESTION}

The majority of protein is consumed at breakfast, lunch, and dinner (34). Some researchers suggest that the distribution of protein intake throughout the day affects net protein balance over a longer period (35-41), while others did not observe an effect of protein feeding pattern (42-44). Despite the ongoing debate on the impact of protein intake pattern throughout the day, it is generally accepted that at least $20 \mathrm{~g}$ of high-quality protein needs to be consumed per meal to stimulate postprandial muscle protein synthesis rates and allow for muscle mass maintenance. As a consequence, it is speculated that increasing dietary protein intake with breakfast might represent 
an effective strategy for dietary interventions aiming to maintain skeletal muscle mass across the lifespan (34). Furthermore, the night generally represents a relatively long period during which net protein balance remains negative due to low levels of circulating amino acids. Ingesting a bolus of protein prior to sleep to enhance aminoacidemia during the night has been shown to stimulate overnight muscle protein synthesis, resulting in a more positive overnight net muscle protein balance $(45,46)$.

Physical activity sensitizes skeletal muscle tissue to the anabolic properties of amino acids by enhancing the muscle protein synthetic response to protein ingestion (47). Furthermore, it was shown that more of the ingested protein was directed towards de novo muscle protein synthesis when physical activity was performed prior to food intake. The stimulatory properties of physical activity on the postprandial muscle protein synthetic response to protein ingestion can persist for up to $24 \mathrm{~h}$ following a single bout of exercise (48). Therefore, daily physical activity is of key relevance to maintain anabolic responsiveness to food ingestion and plays a key role in maintaining skeletal muscle mass.

\section{MACRONUTRIENT COMPOSITION}

Most studies have investigated the muscle protein synthetic response to the ingestion of isolated protein sources. However, dietary protein is generally consumed as part of a product or meal, with carbohydrate and fat (and other nutritional factors) being co-ingested with protein. The presence of fat and/or carbohydrate may modulate dietary protein digestion and absorption kinetics and, as such, postprandial amino acid availability for the stimulation of muscle protein synthesis. In support, amino acid uptake by the leg (indicative of muscle protein anabolism) has been shown to be higher following the ingestion of high fat when compared with skim milk in young males during recovery from resistance type exercise (49). Furthermore, several studies have assessed postprandial muscle protein synthesis rates when carbohydrate is co-ingested with protein under both post-exercise $(50-52)$ and resting conditions $(53,54)$. It could be suggested that the higher insulin response following carbohydrate co-ingestion may enhance the muscle protein synthetic response (19). Conversely, circulating insulin may only be permissive, as opposed to stimulatory, to allow for a postprandial increase in muscle protein synthesis (55) and a moderate rise in circulating insulin may already be sufficient to maximize postprandial muscle protein anabolism (56).

\section{PROTEIN DENSE FOODS}

The matrix in which protein is ingested can modulate the postprandial muscle protein synthetic response. Meal composition, other food products, as well as numerous nutritional components may modulate the postprandial muscle protein synthetic response on a variety of levels. The main protein dense food products that provide a large portion of daily protein intake within a Western diet include dairy products and meat. Relatively few studies have examined the impact of ingesting protein dense foods on postprandial muscle protein synthesis rates. It has been shown that the ingestion of $113 \mathrm{~g}$ lean (90\%) ground beef (containing $30 \mathrm{~g}$ protein, including $10 \mathrm{~g} \mathrm{EAA}$ and $2 \mathrm{~g}$ leucine) stimulates muscle protein synthesis rates in both young and older individuals by $\sim 50 \%$ when compared to post-absorptive muscle protein synthesis rates (57). Ingesting more meat (i.e., $340 \mathrm{~g}$ lean beef containing $90 \mathrm{~g}$ protein) does not seem to further increase postprandial muscle protein synthesis rates, suggesting that the ingestion of $\sim 120 \mathrm{~g}$ lean beef maximizes postprandial muscle protein synthesis rates $(58)$. Others assessed postprandial myofibrillar protein synthesis rates following ingestion of graded intakes of beef $(57,113$, and $170 \mathrm{~g}$ beef corresponding with 12,24 , and 36 g protein, respectively) and observed a measurable increase in 
muscle protein synthesis rates following the ingestion of the higher dose only (59). Similar observations were reported when beef was ingested during recovery from exercise $(59,60)$. Besides meat, various studies have assessed the postprandial muscle protein synthetic response to the ingestion of dairy products. Milk ingestion has been shown to increase muscle protein anabolism $(49,61)$. So far, few studies have compared the muscle protein synthetic responses to the ingestion of different protein dense foods. It could be speculated that food texture can modulate postprandial muscle protein synthesis by affecting protein digestion and absorption kinetics. For instance, it has been shown that gelation of milk slows down gastric emptying, delays amino acid absorption, and attenuates the postprandial rise in circulating amino acid concentrations $(62,63)$. For solid foods such as meat, the speed of protein digestion can be modulated by mincing. Minced beef is more rapidly digested and absorbed when compared with beef steak, resulting in a more rapid release of beef protein-derived amino acids in the systemic circulation, thereby creating a more positive postprandial net protein balance in the elderly (64). Similarly, in older individuals with impaired chewing efficiency, the rate of meat protein digestion, the postprandial rise in plasma amino acid concentrations, as well as the subsequent utilization for protein synthesis is reduced (65).

\section{STABLE ISOTOPE TRACER METHODOLOGY}

Muscle protein synthesis rates are traditionally being determined using primed continuous infusions of stable isotope-labeled amino acid tracers in combination with the collection of blood samples and muscle biopsies (66). Amino acids serve as precursors for de novo muscle protein synthesis. The use of stable isotope-labeled amino acids allows for tracing the infused amino acids in the free amino acid pool (i.e. plasma or intracellular fluid) as well as the protein-bound amino acid pool (i.e. muscle protein). After approximately $1.5 \mathrm{~h}$ of infusion, a steady state in free amino acid pool enrichment may be reached. During this steady state, the labeled amino acids are incorporated into muscle protein at a relative linear and constant rate (66). By measuring the increment in muscle protein-bound enrichment between two muscle biopsies over time and dividing this by the average enrichment in the free amino acid pool, the fractional synthetic rate of muscle protein synthesis can be determined. Using this precursor-product methodology, muscle protein synthesis rates during basal, post-absorptive conditions have successfully been determined in a variety of populations (aging, diseased, etc.).

The assessment of muscle protein synthesis rates during postprandial conditions is more challenging. Dietary protein will be digested and absorbed and protein-derived amino acids will enter the free amino acid pool. Entry of dietary protein-derived amino acids into the free amino acid pool will disturb (i.e. dilute) the steady state in free amino acid pool enrichment attained during a continuous intravenous infusion of stable isotope-labeled amino acids. To overcome this methodological problem, three solutions have been developed. First, the ingestion of protein in small boluses every 20 min results in a continuous release of dietary protein-derived amino acids into the free amino acid pool (67). This lowers but does not disturb the steady state in precursor pool enrichment. However, ingesting protein in repeated boluses does not reflect a real-world setting. Secondly, the ingestion of a protein beverage enriched with stable isotope-labeled amino acids will provide both labeled and unlabeled amino acids to enter the free amino acid pool (68). Provided that the enrichment of the protein beverage matches the target enrichment of the free amino acid precursor pool, the steady state in the free amino acid pool enrichment may be maintained. However, the added stable isotope-labeled amino acids follow a different pattern of absorption when compared with the dietary protein-derived amino acids. As such, a disturbance 
of the steady state in free amino acid pool enrichment remains apparent. Finally, the use of intrinsically labeled protein with an enrichment level matching the target enrichment level of the free amino acid precursor pool (69), allows for maintaining near perfect steady state enrichment for determining postprandial muscle protein synthesis rates.

Boirie et al. (70) were the first to produce intrinsically labeled protein by infusing stable isotopelabeled amino acids into a lactating cow, collecting the milk, and isolating the casein and whey protein fractions from the milk. Using this intrinsically labeled protein, this research group was able to assess protein digestion and absorption kinetics in vivo in humans. They observed that whey protein is digested and absorbed more rapidly when compared with casein, which influenced postprandial amino acid metabolism (10). Our lab extended on this work by infusing larger quantities of stable isotope-labeled amino acids into a lactating cow, which resulted in the production of intrinsically labeled protein with a high enrichment level ( 30\%; Figure 1.2) $(71,72)$. The highly labeled protein allowed us to assess dietary protein digestion and absorption kinetics as well as the incorporation of dietary protein-derived amino acids into skeletal muscle protein (12, $13,23,24,45-47)$, which is a more direct measurement of the metabolic fate of dietary proteinderived amino acids and their role as precursors for de novo postprandial muscle protein synthesis. In 2010, Reitelseder et al. (69) used the ingestion of lowly labeled protein ( 10\%) in combination with continuous infusion of stable isotope-labeled amino acids to be able to determine muscle protein synthesis rates using the precursor-product method under steady state conditions. We have recently combined these methodological approaches by infusing two distinct stable isotopelabeled amino acids into a lactating cow, thereby producing doubly labeled protein (with both a high and relatively low enrichment level) (73). The use of doubly labeled protein in combination with the infusion of stable isotope-labeled amino acids allows us to determine dietary protein digestion and absorption kinetics, muscle protein synthesis rates, as well as the incorporation of dietary protein-derived amino acids into de novo muscle protein (74).
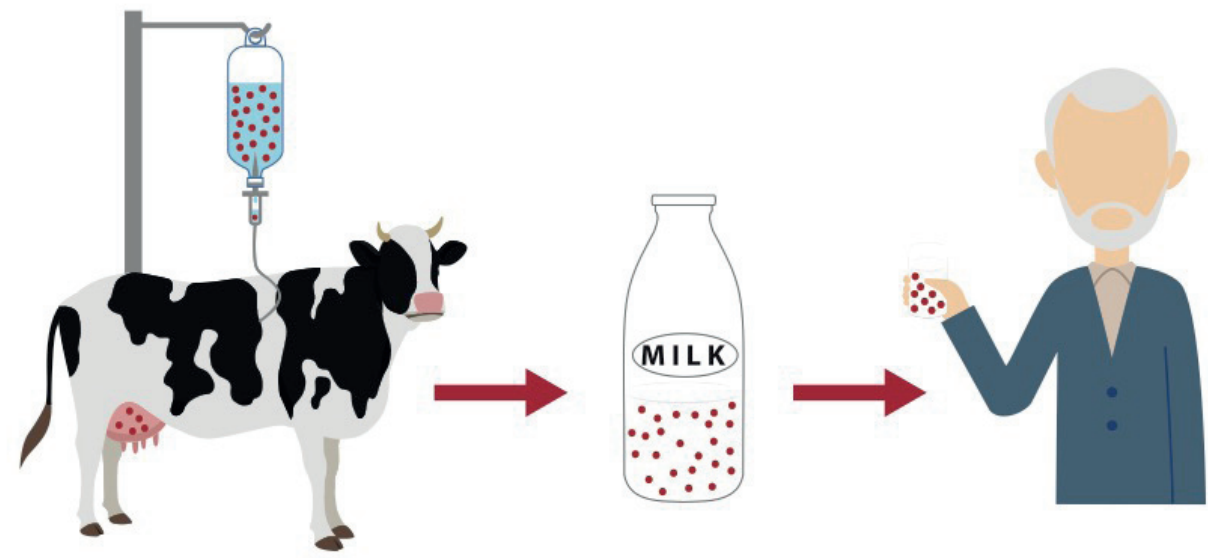

Figure 1.2 | Schematic representation of the production of doubly labeled milk protein. 


\section{OUTLINE OF THE DISSERTATION}

Adequate dietary protein intake is a prerequisite to maintain skeletal muscle mass by directly stimulating muscle protein synthesis. Protein is generally consumed as part of a meal, with carbohydrate and fat being co-ingested with protein. In chapter 2 we assess the effects of carbohydrate co-ingestion with protein on dietary protein digestion and absorption kinetics as well as subsequent postprandial muscle protein synthesis rates in young and older men. In chapter $\mathbf{3}$ we investigate protein digestion and absorption as well as the muscle protein synthetic response to the ingestion of protein with or without fat in older males. After investigating the individual effects of co-ingesting carbohydrates or fat with protein, we studied two commonly consumed protein-dense foods with different macronutrient composition and texture, i.e. milk and beef, in chapter 4. Specifically, we describe the differential effects in postprandial protein handling after beef versus milk ingestion during post-exercise recovery in young men. Besides animalderived protein sources, our diet also provides ample protein from plant-based protein sources. It is often suggested that plant-based proteins are suboptimal for the stimulation of muscle protein synthesis rates when compared with animal-derived proteins. However, animal-derived proteins are expensive and less available in low-income countries. Plant-based proteins are more costeffective and sustainable, and may represent an alternative protein source for the stimulation of muscle protein synthesis rates. Chapter 5 evaluates the anabolic properties of wheat protein (most predominant source of plant-based proteins) when compared with casein and whey protein. Though these data provide a complete and comprehensive insight in postprandial protein handling following the ingestion of a single meal-like bolus of protein, no studies have addressed whether postprandial protein handling is modulated by the level of habitual protein consumption. In chapter $\mathbf{6}$ we determine the impact of habituation to low versus high protein intake on basal muscle protein synthesis rates, dietary protein digestion and amino acid absorption kinetics, and the postprandial muscle protein synthetic response to the ingestion of a single, meal-like amount of protein. 


\section{References}

1. WHO. World report on ageing and health. 2015

2. Rosenberg IH. Sarcopenia: origins and clinical relevance. J Nutr 1997;127(5 Suppl):990S-1S.

3. Burd NA, Tang JE, Moore DR, Phillips SM. Exercise training and protein metabolism: influences of contraction, protein intake, and sex-based differences. Journal of applied physiology (Bethesda, Md : 1985) 2009;106(5):1692-701.

4. Volpi E, Sheffield-Moore M, Rasmussen BB, Wolfe RR. Basal muscle amino acid kinetics and protein synthesis in healthy young and older men. Jama 2001;286(10):1206-12.

5. Cuthbertson D, Smith K, Babraj J, Leese G, Waddell T, Atherton P, Wackerhage H, Taylor PM, Rennie MJ. Anabolic signaling deficits underlie amino acid resistance of wasting, aging muscle. Faseb J 2005;19(3):422-4.

6. Katsanos CS, Kobayashi H, Sheffield-Moore M, Aarsland A, Wolfe RR. Aging is associated with diminished accretion of muscle proteins after the ingestion of a small bolus of essential amino acids. The American journal of clinical nutrition 2005;82(5):1065-73.

7. Volpi E, Mittendorfer B, Rasmussen BB, Wolfe RR. The response of muscle protein anabolism to combined hyperaminoacidemia and glucose-induced hyperinsulinemia is impaired in the elderly. J Clin Endocrinol Metab 2000;85(12):4481-90.

8. Burd NA, Gorissen SH, van Loon LJ. Anabolic resistance of muscle protein synthesis with aging. Exercise and sport sciences reviews 2013;41(3):169-73.

9. Rennie MJ. Anabolic resistance: the effects of aging, sexual dimorphism, and immobilization on human muscle protein turnover. Appl Physiol Nutr Metab 2009;34(3):377-81.

10. Boirie Y, Dangin M, Gachon P, Vasson MP, Maubois JL, Beaufrere B. Slow and fast dietary proteins differently modulate postprandial protein accretion. Proc Natl Acad Sci U S A 1997;94(26):14930-5.

11. Dangin M, Boirie Y, Garcia-Rodenas C, Gachon P, Fauquant J, Callier P, Ballevre O, Beaufrere B. The digestion rate of protein is an independent regulating factor of postprandial protein retention. American journal of physiology Endocrinology and metabolism 2001;280(2):E340-8.

12. Koopman R, Crombach N, Gijsen AP, Walrand S, Fauquant J, Kies AK, Lemosquet S, Saris WH, Boirie Y, van Loon LJ. Ingestion of a protein hydrolysate is accompanied by an accelerated in vivo digestion and absorption rate when compared with its intact protein. The American journal of clinical nutrition 2009;90(1):106-15.

13. Pennings B, Boirie Y, Senden JM, Gijsen AP, Kuipers H, van Loon LJ. Whey protein stimulates postprandia muscle protein accretion more effectively than do casein and casein hydrolysate in older men. Am J Clin Nutr 2011;93(5):997-1005.

14. West DW, Burd NA, Coffey VG, Baker SK, Burke LM, Hawley JA, Moore DR, Stellingwerff T, Phillips SM. Rapid aminoacidemia enhances myofibrillar protein synthesis and anabolic intramuscular signaling responses after resistance exercise. The American journal of clinical nutrition 2011;94(3):795-803.

15. Boirie Y, Gachon P, Beaufrere B. Splanchnic and whole-body leucine kinetics in young and elderly men. Am J Clin Nutr 1997;65(2):489-95

16. Volpi E, Mittendorfer B, Wolf SE, Wolfe RR. Oral amino acids stimulate muscle protein anabolism in the elderly despite higher first-pass splanchnic extraction. Am J Physiol 1999;277(3 Pt 1):E513-20.

17. Timmerman KL, Lee JL, Dreyer HC, Dhanani S, Glynn EL, Fry CS, Drummond MJ, Sheffield-Moore M, Rasmussen BB, Volpi E. Insulin stimulates human skeletal muscle protein synthesis via an indirect mechanism involving endothelial-dependent vasodilation and mammalian target of rapamycin complex 1 signaling. The Journal of clinical endocrinology and metabolism 2010;95(8):3848-57.

18. Timmerman KL, Lee JL, Fujita S, Dhanani S, Dreyer HC, Fry CS, Drummond MJ, Sheffield-Moore M, Rasmussen BB, Volpi E. Pharmacological vasodilation improves insulin-stimulated muscle protein anabolism but not glucose utilization in older adults. Diabetes 2010;59(11):2764-71.

19. Fujita S, Glynn EL, Timmerman KL, Rasmussen BB, Volpi E. Supraphysiological hyperinsulinaemia is necessary to stimulate skeletal muscle protein anabolism in older adults: evidence of a true age-related insulin resistance of muscle protein metabolism. Diabetologia 2009;52(9):1889-98.

20. Rasmussen BB, Fujita S, Wolfe RR, Mittendorfer B, Roy M, Rowe VL, Volpi E. Insulin resistance of muscle protein metabolism in aging. FASEB journal : official publication of the Federation of American Societies for Experimental Biology 2006;20(6):768-9.

21. Drummond MJ, Glynn EL, Fry CS, Timmerman KL, Volpi E, Rasmussen BB. An increase in essential amino acid availability upregulates amino acid transporter expression in human skeletal muscle. Am J Physiol Endocrinol Metab 2010;298(5):E1011-8.

22. Guillet C, Prod'homme M, Balage M, Gachon P, Giraudet C, Morin L, Grizard J, Boirie Y. Impaired anabolic response of muscle protein synthesis is associated with S6K1 dysregulation in elderly humans. Faseb J 2004;18(13):1586-7.

23. Pennings B, Groen B, de Lange A, Gijsen AP, Zorenc AH, Senden JM, van Loon LJ. Amino acid absorption and subsequent muscle protein accretion following graded intakes of whey protein in elderly men. Am $\mathrm{J}$ Physiol Endocrinol Metab 2012;302(8):E992-9.

24. Koopman R, Walrand S, Beelen M, Gijsen AP, Kies AK, Boirie Y, Saris WH, van Loon LJ. Dietary protein digestion and absorption rates and the subsequent postprandial muscle protein synthetic response do not differ between young and elderly men. The Journal of nutrition 2009;139(9):1707-13. 
Tang JE, Moore DR, Kujbida GW, Tarnopolsky MA, Phillips SM. Ingestion of whey hydrolysate, casein, or soy protein isolate: effects on mixed muscle protein synthesis at rest and following resistance exercise in young men. Journal of applied physiology (Bethesda, Md: 1985) 2009;107(3):987-92.

26. Yang Y, Churchward-Venne TA, Burd NA, Breen L, Tarnopolsky MA, Phillips SM. Myofibrillar protein synthesis following ingestion of soy protein isolate at rest and after resistance exercise in elderly men. Nutrition \& metabolism 2012;9(1):57.

27. Fouillet H, Mariotti F, Gaudichon C, Bos C, Tome D. Peripheral and splanchnic metabolism of dietary nitrogen are differently affected by the protein source in humans as assessed by compartmental modeling. The Journal of nutrition 2002;132(1):125-33.

28. Moore DR, Robinson MJ, Fry JL, Tang JE, Glover El, Wilkinson SB, Prior T, Tarnopolsky MA, Phillips SM. Ingested protein dose response of muscle and albumin protein synthesis after resistance exercise in young men. The American journal of clinical nutrition 2009;89(1):161-8.

29. Mahe S, Roos N, Benamouzig R, Davin L, Luengo C, Gagnon L, Gausserges N, Rautureau J, Tome D. Gastrojejunal kinetics and the digestion of [15N]beta-lactoglobulin and casein in humans: the influence of the nature and quantity of the protein. Am J Clin Nutr 1996;63(4):546-52.

30. Katsanos CS, Kobayashi H, Sheffield-Moore M, Aarsland A, Wolfe RR. A high proportion of leucine is required for optimal stimulation of the rate of muscle protein synthesis by essential amino acids in the elderly. American journal of physiology Endocrinology and metabolism 2006;291(2):E381-7.

31. Rieu I, Balage M, Sornet C, Giraudet C, Pujos E, Grizard J, Mosoni L, Dardevet D. Leucine supplementation improves muscle protein synthesis in elderly men independently of hyperaminoacidaemia. The Journal of physiology 2006;575(Pt 1):305-15.

32. Wall BT, Hamer HM, de Lange A, Kiskini A, Groen BB, Senden JM, Gijsen AP, Verdijk LB, van Loon LJ. Leucine coingestion improves post-prandial muscle protein accretion in elderly men. Clinical nutrition 2013;32(3):412-9.

33. Witard OC, Jackman SR, Breen L, Smith K, Selby A, Tipton KD. Myofibrillar muscle protein synthesis rates subsequent to a meal in response to increasing doses of whey protein at rest and after resistance exercise. The American journal of clinical nutrition 2014;99(1):86-95.

34. Tieland M, Borgonjen-Van den Berg KJ, van Loon LJ, de Groot LC. Dietary protein intake in communitydwelling, frail, and institutionalized elderly people: scope for improvement. European journal of nutrition 2012;51(2):173-9.

35. Areta JL, Burke LM, Ross ML, Camera DM, West DW, Broad EM, Jeacocke NA, Moore DR, Stellingwerff T, Phillips $\mathrm{SM}$, et al. Timing and distribution of protein ingestion during prolonged recovery from resistance exercise alters myofibrillar protein synthesis. The Journal of physiology 2013;591(Pt 9):2319-31.

36. Arnal MA, Mosoni L, Boirie Y, Houlier ML, Morin L, Verdier E, Ritz P, Antoine JM, Prugnaud J, Beaufrere B, et al. Protein pulse feeding improves protein retention in elderly women. Am J Clin Nutr 1999;69(6):1202-8.

37. Mamerow MM, Mettler JA, English KL, Casperson SL, Arentson-Lantz E, Sheffield-Moore M, Layman DK, PaddonJones D. Dietary protein distribution positively influences 24 -h muscle protein synthesis in healthy adults. J Nutr 2014;144(6):876-80.

38. Moore DR, Areta J, Coffey VG, Stellingwerff T, Phillips SM, Burke LM, Cleroux M, Godin JP, Hawley JA. Daytime pattern of post-exercise protein intake affects whole-body protein turnover in resistance-trained males. Nutrition \& metabolism 2012;9(1):91.

39. Arnal MA, Mosoni L, Boirie Y, Gachon P, Genest M, Bayle G, Grizard J, Arnal M, Antoine JM, Beaufrere B, et al. Protein turnover modifications induced by the protein feeding pattern still persist after the end of the diets. Am J Physiol Endocrinol Metab 2000;278(5):E902-9.

40. Bouillanne O, Curis E, Hamon-Vilcot B, Nicolis I, Chretien P, Schauer N, Vincent JP, Cynober L, Aussel C. Impact of protein pulse feeding on lean mass in malnourished and at-risk hospitalized elderly patients: a randomized controlled trial. Clin Nutr 2013;32(2):186-92.

41. Bouillanne O, Neveux N, Nicolis I, Curis E, Cynober L, Aussel C. Long-lasting improved amino acid bioavailability associated with protein pulse feeding in hospitalized elderly patients: a randomized controlled trial. Nutrition 2014;30(5):544-50.

42. Kim IY, Schutzler S, Schrader A, Spencer H, Kortebein P, Deutz NE, Wolfe RR, Ferrando AA. Quantity of dietary protein intake, but not pattern of intake, affects net protein balance primarily through differences in protein synthesis in older adults. American journal of physiology Endocrinology and metabolism 2015;308(1):E21-8.

43. Adechian S, Balage M, Remond D, Migne C, Quignard-Boulange A, Marset-Baglieri A, Rousset S, Boirie $Y$, Gaudichon C, Dardevet D, et al. Protein feeding pattern, casein feeding, or milk-soluble protein feeding did not change the evolution of body composition during a short-term weight loss program. American journal of physiology Endocrinology and metabolism 2012;303(8):E973-82.

44. Arnal MA, Mosoni L, Boirie Y, Houlier ML, Morin L, Verdier E, Ritz P, Antoine JM, Prugnaud J, Beaufrere B, et al. Protein feeding pattern does not affect protein retention in young women. J Nutr 2000;130(7):1700-4.

45. Groen BB, Res PT, Pennings B, Hertle E, Senden JM, Saris WH, van Loon LJ. Intragastric protein administration stimulates overnight muscle protein synthesis in elderly men. Am J Physiol Endocrinol Metab 2012;302(1):E5260.

46. Res PT, Groen B, Pennings B, Beelen M, Wallis GA, Gijsen AP, Senden JM, LJ VANL. Protein ingestion before sleep improves postexercise overnight recovery. Medicine and science in sports and exercise 2012;44(8):1560-9. 
47.

Pennings B, Koopman R, Beelen M, Senden JM, Saris WH, van Loon LJ. Exercising before protein intake allows for greater use of dietary protein-derived amino acids for de novo muscle protein synthesis in both young and elderly men. The American journal of clinical nutrition 2011;93(2):322-31.

48. Burd NA, West DW, Moore DR, Atherton PJ, Staples AW, Prior T, Tang JE, Rennie MJ, Baker SK, Phillips SM Enhanced amino acid sensitivity of myofibrillar protein synthesis persists for up to $24 \mathrm{~h}$ after resistance exercise in young men. The Journal of nutrition 2011;141(4):568-73.

49. Elliot TA, Cree MG, Sanford AP, Wolfe RR, Tipton KD. Milk ingestion stimulates net muscle protein synthesis following resistance exercise. Med Sci Sports Exerc 2006;38(4):667-74.

50. Glynn EL, Fry CS, Drummond MJ, Dreyer HC, Dhanani S, Volpi E, Rasmussen BB. Muscle protein breakdown has a minor role in the protein anabolic response to essential amino acid and carbohydrate intake following resistance exercise. American journal of physiology Regulatory, integrative and comparative physiology 2010;299(2):R533-40.

51. Koopman R, Beelen M, Stellingwerff T, Pennings B, Saris WH, Kies AK, Kuipers H, van Loon LJ. Coingestion of carbohydrate with protein does not further augment postexercise muscle protein synthesis. American journal of physiology Endocrinology and metabolism 2007;293(3):E833-42.

52. Staples AW, Burd NA, West DW, Currie KD, Atherton PJ, Moore DR, Rennie MJ, Macdonald MJ, Baker SK, Phillips SM. Carbohydrate does not augment exercise-induced protein accretion versus protein alone. Medicine and science in sports and exercise 2011;43(7):1154-61.

53. Glynn EL, Fry CS, Timmerman KL, Drummond MJ, Volpi E, Rasmussen BB. Addition of carbohydrate or alanine to an essential amino acid mixture does not enhance human skeletal muscle protein anabolism. J Nutr 2013;143(3):307-14.

54. Hamer HM, Wall BT, Kiskini A, de Lange A, Groen BB, Bakker JA, Gijsen AP, Verdijk LB, van Loon LJ. Carbohydrate co-ingestion with protein does not further augment post-prandial muscle protein accretion in older men. Nutr Metab (Lond) 2013;10(1):15.

55. Phillips SM. Insulin and muscle protein turnover in humans: stimulatory, permissive, inhibitory, or all of the above? American journal of physiology Endocrinology and metabolism 2008;295(4):E731.

56. Greenhaff PL, Karagounis LG, Peirce N, Simpson EJ, Hazell M, Layfield R, Wackerhage H, Smith K, Atherton P, Selby $A$, et al. Disassociation between the effects of amino acids and insulin on signaling, ubiquitin ligases, and protein turnover in human muscle. Am J Physiol Endocrinol Metab 2008;295(3):E595-604.

57. Symons TB, Schutzler SE, Cocke TL, Chinkes DL, Wolfe RR, Paddon-Jones D. Aging does not impair the anabolic response to a protein-rich meal. Am J Clin Nutr 2007;86(2):451-6.

58. Symons TB, Sheffield-Moore M, Wolfe RR, Paddon-Jones D. A moderate serving of high-quality protein maximally stimulates skeletal muscle protein synthesis in young and elderly subjects. Journal of the American Dietetic Association 2009;109(9):1582-6.

59. Robinson MJ, Burd NA, Breen L, Rerecich T, Yang Y, Hector AJ, Baker SK, Phillips SM. Dose-dependent responses of myofibrillar protein synthesis with beef ingestion are enhanced with resistance exercise in middle-aged men. Applied physiology, nutrition, and metabolism = Physiologie appliquee, nutrition et metabolisme 2013;38(2):120-5.

60. Symons TB, Sheffield-Moore M, Mamerow MM, Wolfe RR, Paddon-Jones D. The anabolic response to resistance exercise and a protein-rich meal is not diminished by age. The journal of nutrition, health \& aging $2011 ; 15(5): 376-81$

61. Wilkinson SB, Tarnopolsky MA, Macdonald MJ, Macdonald JR, Armstrong D, Phillips SM. Consumption of fluid skim milk promotes greater muscle protein accretion after resistance exercise than does consumption of an isonitrogenous and isoenergetic soy-protein beverage. The American journal of clinical nutrition 2007;85(4):1031-40.

62. Barbe F, Menard O, Le Gouar Y, Buffiere C, Famelart MH, Laroche B, Feunteun SL, Remond D, Dupont D. Acid and rennet gels exhibit strong differences in the kinetics of milk protein digestion and amino acid bioavailability. Food chemistry 2014;143:1-8.

63. Barbe F, Menard O, Le Gouar Y, Buffiere C, Famelart MH, Laroche B, Le Feunteun S, Dupont D, Remond D. The heat treatment and the gelation are strong determinants of the kinetics of milk proteins digestion and of the peripheral availability of amino acids. Food chemistry 2013;136(3-4):1203-12.

64. Pennings B, Groen BB, van Dijk JW, de Lange A, Kiskini A, Kuklinski M, Senden JM, van Loon LJ. Minced beef is more rapidly digested and absorbed than beef steak, resulting in greater postprandial protein retention in older men. The American journal of clinical nutrition 2013;98(1):121-8.

65. Remond D, Machebeuf M, Yven C, Buffiere C, Mioche L, Mosoni L, Patureau Mirand P. Postprandial whole-body protein metabolism after a meat meal is influenced by chewing efficiency in elderly subjects. Am $\mathrm{J}$ Clin Nutr 2007;85(5):1286-92.

66. Wolfe RR, Chinkes DL, Wolfe RR. Isotope tracers in metabolic research : principles and practice of kinetic analysis. 2nd ed. Hoboken, N.J.: Wiley-Liss, 2005.

67. Wagenmakers AJ. Tracers to investigate protein and amino acid metabolism in human subjects. The Proceedings of the Nutrition Society 1999;58(4):987-1000.

68. Burd NA, West DW, Rerecich T, Prior T, Baker SK, Phillips SM. Validation of a single biopsy approach and bolus protein feeding to determine myofibrillar protein synthesis in stable isotope tracer studies in humans. Nutr Metab (Lond) 2011;8:15. 
69. Reitelseder S, Agergaard J, Doessing S, Helmark IC, Lund P, Kristensen NB, Frystyk J, Flyvbjerg A, Schjerling P, van Hall G, et al. Whey and casein labeled with L-[1-13C]leucine and muscle protein synthesis: effect of resistance exercise and protein ingestion. Am J Physiol Endocrinol Metab 2011;300(1):E231-42.

70. Boirie Y, Fauquant J, Rulquin H, Maubois JL, Beaufrere B. Production of large amounts of [13C]leucine-enriched milk proteins by lactating cows. J Nutr 1995;125(1):92-8.

71. Pennings B, Pellikaan WF, Senden JM, van Vuuren AM, Sikkema J, van Loon LJ. The production of intrinsically labeled milk and meat protein is feasible and provides functional tools for human nutrition research. J Dairy Sci 2011;94(9):4366-73.

72. van Loon LJ, Boirie Y, Gijsen AP, Fauquant J, de Roos AL, Kies AK, Lemosquet S, Saris WH, Koopman R. The production of intrinsically labeled milk protein provides a functional tool for human nutrition research. J Dairy Sci 2009;92(10):4812-22.

73. Burd NA, Hamer HM, Pennings B, Pellikaan WF, Senden JM, Gijsen AP, van Loon LJ. Substantial Differences between Organ and Muscle Specific Tracer Incorporation Rates in a Lactating Dairy Cow. PLoS One 2013;8(6):e68109.

74. Burd NA, Cermak NM, Kouw IW, Gorissen SH, Gijsen AP, van Loon LJ. The use of doubly labeled milk protein to measure postprandial muscle protein synthesis rates in vivo in humans. Journal of applied physiology (Bethesda, Md : 1985) 2014;117(11):1363-70. 


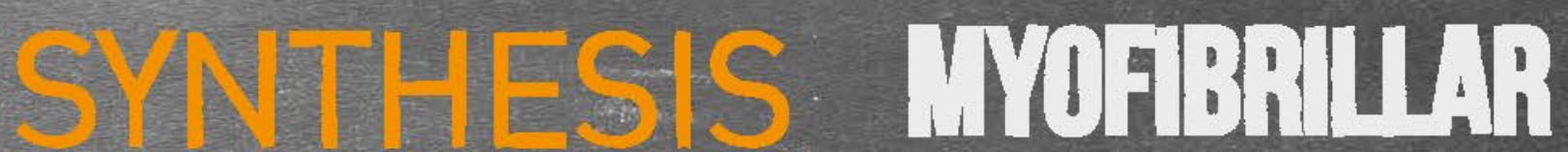

CHAPTER 2

Carbohydrate co-ingestion delays dietary protein digestion and absorption but does not modulate postprandial muscle protein accretion

Stefan H.M. Gorissen Nicholas A. Burd Henrike M. Hamer Annemie P. Gijsen

Bart B.L. Groen Luc J.C. van Loon

J Clin Endocrinol Metab. 2014 Jun;99(6):2250-8
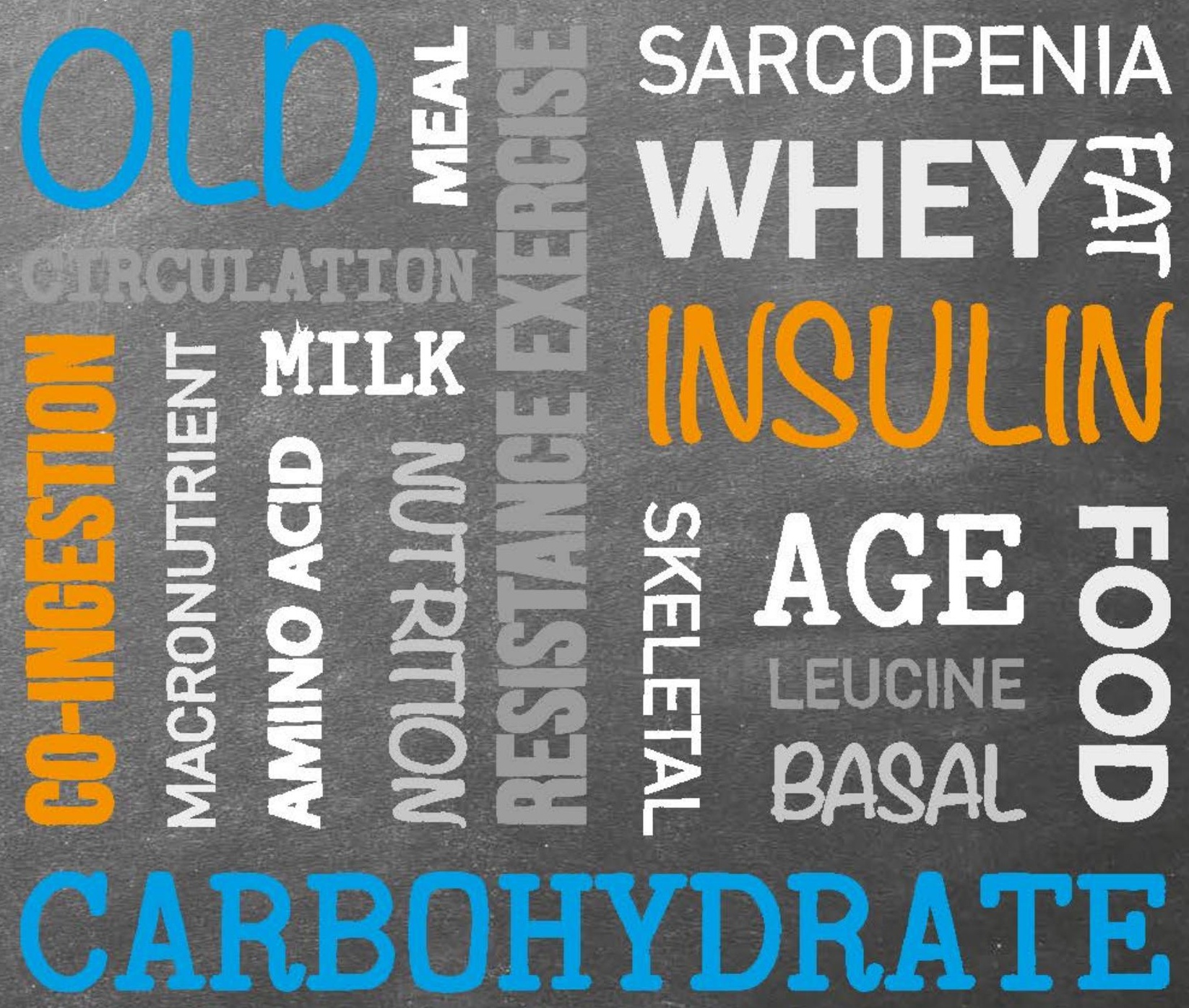


\section{ABSTRACT}

BACKGROUND: Dietary protein digestion and absorption is an important factor modulating muscle protein accretion. However, there are few data available on the effects of co-ingesting other macronutrients with protein on digestion and absorption kinetics and the subsequent muscle protein synthetic response.

OBJECTIVE: To determine the impact of carbohydrate co-ingestion with protein on dietary protein digestion and absorption and muscle protein accretion in healthy young and older men.

DESIGN: Twenty-four healthy young (age: $21 \pm 1 \mathrm{y}, \mathrm{BMI}: 21.8 \pm 0.5 \mathrm{~kg} \cdot \mathrm{m}^{-2}$ ) and 25 older (age: $75 \pm 1 \mathrm{y}$, BMI: $25.4 \pm 0.6 \mathrm{~kg} \cdot \mathrm{m}^{-2}$ ) men received a primed continuous L-[ring- $\left.{ }^{2} \mathrm{H}_{5}\right]$-phenylalanine and L-[ring-3,5$\left.{ }^{2} \mathrm{H}_{2}\right]$-tyrosine infusion and ingested $20 \mathrm{~g}$ intrinsically $\mathrm{L}-\left[1-{ }^{13} \mathrm{C}\right]$-phenylalanine-labeled protein with (Pro+CHO) or without (Pro) $60 \mathrm{~g}$ carbohydrate. Plasma samples and muscle biopsies were collected in a post-absorptive and postprandial state.

RESULTS: Carbohydrate co-ingestion delayed the appearance of exogenous phenylalanine in the circulation $(P=0.001)$. Dietary protein-derived phenylalanine availability over the $5 \mathrm{~h}$ postprandial period was lower in the older (62 $\pm 2 \%)$ when compared with the young subjects ( $74 \pm 2 \% ; P=0.007)$, with no differences between conditions $(P=0.20)$. Carbohydrate co-ingestion did not modulate postprandial muscle protein synthesis rates $(0.035 \pm 0.003$ vs $0.043 \pm 0.004$ and $0.033 \pm 0.002$ vs $0.035 \pm 0.003 \% \cdot \mathrm{h}^{-1}$ following Pro vs Pro $+\mathrm{CHO}$ in the young and older group, respectively). In accordance, no differences in muscle protein-bound $\mathrm{L}-\left[1-{ }^{13} \mathrm{C}\right]$-phenylalanine enrichments were observed between conditions $(0.020 \pm 0.002$ vs $0.020 \pm 0.002$ and $0.019 \pm 0.003$ vs $0.022 \pm 0.004$ mole percent excess following Pro vs Pro+CHO in the young and older subjects, respectively).

CONCLUSION: Carbohydrate co-ingestion with protein delays dietary protein digestion and absorption, but does not modulate postprandial muscle protein accretion in healthy young or older men. 


\section{INTRODUCTION}

The age-related loss of skeletal muscle mass, referred to as sarcopenia, is at least partly attributed to a blunted muscle protein synthetic response to food intake (1-6). There are numerous factors that occur between protein intake and the stimulation of muscle protein synthesis that may underpin the impaired postprandial muscle protein synthetic response at a more advanced age (7). Impaired dietary protein digestion and absorption and/or increased splanchnic extraction, may restrict postprandial plasma amino acid availability, thereby contributing to the proposed agerelated differences in postprandial muscle protein accretion (8-10). However, previous work from our group has shown that protein digestion and absorption and subsequent amino acid availability do not differ between healthy young and older adults following ingestion of a single bolus of protein $(11,12)$. So far, there are few data available on the impact of co-ingesting other macronutrients with protein on dietary protein digestion and absorption and the subsequent muscle protein synthetic response to food intake.

Another factor that may contribute to the blunted muscle protein synthetic response of senescent muscle to protein intake (anabolic resistance) is the reduced capacity of postprandial insulin to stimulate endothelial-dependent increases in skeletal muscle perfusion (6). In the older population, higher postprandial plasma insulin concentrations may be required to allow for optimal amino acid delivery to the muscle and, as such, to maintain (or restore) a normal postprandial muscle protein synthetic response (3). We hypothesize that carbohydrate coingestion with protein enhances postprandial insulin concentrations and, as such, may further augment postprandial muscle protein accretion particularly in old individuals.

The present study investigates the effects of carbohydrate co-ingestion with a single meal-like amount of intact protein on dietary protein digestion and absorption kinetics, whole-body protein metabolism, and postprandial muscle protein accretion in healthy young and older men. To assess both protein digestion and absorption kinetics as well as dietary protein-derived amino acid incorporation into skeletal muscle protein, we combined intravenous infusion of stable isotope labeled amino acids with the ingestion of specifically produced intrinsically labeled protein (13, 14). This is the first study to provide a detailed overview on the effect of protein and protein plus carbohydrate ingestion on dietary protein digestion and absorption kinetics and the subsequent muscle protein synthetic response in young and elderly men. 


\section{MetHODS}

\section{PARTICIPANTS}

Twenty-four healthy young men ( $21 \pm 1 \mathrm{y})$ and 25 healthy elderly men $(75 \pm 1 \mathrm{y})$ participated in this parallel group, randomized controlled trial. The trial was conducted between August 2011 and March 2012, at Maastricht University in Maastricht, the Netherlands. Participants' characteristics are presented in Table 2.1. None of the participants were involved in a regular exercise program. All participants were informed about the purpose of the study, the experimental procedures, and all its possible risks prior to providing written consent to participate. This study was approved by the Medical Ethics Committee from the Academic Hospital Maastricht and procedures followed were in accordance with the ethical standards of the responsible institutional or regional committee on human experimentation or in accordance with the Helsinki Declaration of 1975 as revised in 1983.

Table 2.1 | Subjects' characteristics

\begin{tabular}{|c|c|c|c|c|c|c|}
\hline & \multicolumn{2}{|c|}{ Young } & \multicolumn{2}{|c|}{ Old } & \multicolumn{2}{|c|}{$P$ Value } \\
\hline & $\begin{array}{c}\text { Pro } \\
(n=12)\end{array}$ & $\begin{array}{c}\text { Pro+CHO } \\
(n=12)\end{array}$ & $\begin{array}{c}\text { Pro } \\
(n=12)\end{array}$ & $\begin{array}{c}\text { Pro+CHO } \\
(n=13)\end{array}$ & Age & Treatment \\
\hline Age (y) & $21 \pm 1$ & $20 \pm 1$ & $74 \pm 1$ & $76 \pm 1$ & $<0.001$ & 0.400 \\
\hline Weight (kg) & $70.9 \pm 3.2$ & $76.1 \pm 2.8$ & $75.0 \pm 4.2$ & $79.6 \pm 2.7$ & 0.247 & 0.134 \\
\hline $\mathrm{BMI}\left(\mathrm{kg} \cdot \mathrm{m}^{-2}\right)$ & $21.3 \pm 0.7$ & $22.4 \pm 0.7$ & $24.8 \pm 1.1$ & $25.9 \pm 0.7$ & $<0.001$ & 0.166 \\
\hline Systolic blood pressure $(\mathrm{mmHg})$ & $116 \pm 4$ & $119 \pm 3$ & $135 \pm 5$ & $137 \pm 5$ & $<0.001$ & 0.609 \\
\hline Diastolic blood pressure $(\mathrm{mmHg})$ & $66 \pm 2$ & $65 \pm 2$ & $72 \pm 2$ & $70 \pm 3$ & 0.033 & 0.543 \\
\hline Fat (\%) & $15.3 \pm 1.2$ & $15.0 \pm 1.1$ & $20.2 \pm 1.3$ & $22.1 \pm 1.1$ & $<0.001$ & 0.458 \\
\hline Lean body mass (kg) & $57.5 \pm 2.1$ & $61.9 \pm 1.8$ & $57.3 \pm 2.6$ & $59.3 \pm 1.8$ & 0.487 & 0.135 \\
\hline Appendicular lean mass (kg) & $25.9 \pm 1.0$ & $28.5 \pm 1.0$ & $24.5 \pm 1.1$ & $25.0 \pm 0.9$ & 0.016 & 0.134 \\
\hline Quadriceps CSA $\left(\mathrm{cm}^{2}\right)$ & $73.3 \pm 2.8$ & $76.9 \pm 4.3$ & $61.8 \pm 3.2$ & $59.1 \pm 3.1$ & $<0.001$ & 0.911 \\
\hline $\mathrm{HbA}_{1 \mathrm{c}}(\%)$ & $5.2 \pm 0.1$ & $5.4 \pm 0.1$ & $5.6 \pm 0.1$ & $5.8 \pm 0.1$ & $<0.001$ & 0.048 \\
\hline OGIS $\left(\mathrm{mL} \cdot \mathrm{min}^{-1} \cdot \mathrm{m}^{-2}\right)$ & $446 \pm 9$ & $419 \pm 11$ & $391 \pm 16$ & $364 \pm 15$ & $<0.001$ & 0.043 \\
\hline
\end{tabular}

Abbreviations: CSA, cross-sectional area; $\mathrm{HbA}_{1 c}$, glycosylated hemoglobin; OGIS, oral glucose insulin sensitivity. Values are means \pm SEM. Data were analyzed by Univariate ANOVA with age and treatment as factors. No age $\times$ treatment interaction was observed.

PRETESTING

Participants underwent a medical screening to assess their $\mathrm{HbA}_{1 c}$, glucose tolerance (by a 2-h oral glucose tolerance test (15)), blood pressure, weight, height, and body composition (by Dualenergy X-ray absorptiometry; Discovery A; Hologic, Bedford, MA). A computed tomography scan was performed on the upper leg to determine the cross-sectional area of the quadriceps muscle. The participants were deemed healthy based on their responses to a routine medical screening questionnaire and the screening results. Afterwards, participants were randomly assigned to ingest either casein (Pro) or casein in combination with carbohydrate (Pro+CHO). Randomization was computer-generated and participants, researchers, and technicians were blinded to the group allocation. Beverages were prepared in coded containers by an independent research assistant. 


\section{DIET AND PHYSICAL ACTIVITY CONTROL}

All participants were instructed to refrain from any sort of strenuous physical activity and to maintain their diet as constant as possible for $2 \mathrm{~d}$ prior to the experimental infusions. On the evening before the infusion trial, all participants consumed a standardized meal $\left(32.5 \pm 0.7 \mathrm{~kJ}^{\mathrm{kg}} \mathrm{g}^{-1}\right.$ body weight) composed of 16 energy percent (En\%) protein, 33 En\% carbohydrate, and 51 En\% fat.

\section{INFUSION PROTOCOL}

At $0800 \mathrm{~h}$ following an overnight fast, participants arrived at the laboratory by car or public transport. A Teflon catheter was inserted into an antecubital vein for stable isotope infusion. A second Teflon catheter was inserted into a dorsal hand vein of the contralateral arm and placed in a hot-box $\left(60^{\circ} \mathrm{C}\right)$ for arterialized blood sampling (16). After taking a baseline blood sample, the plasma phenylalanine and tyrosine pools were primed with a single dose of L-[ring- $\left.{ }^{2} \mathrm{H}_{5}\right]-$ phenylalanine $\left(2 \mu \mathrm{mol} \cdot \mathrm{kg}^{-1}\right)$ and L-[ring-3,5- $\left.{ }^{2} \mathrm{H}_{2}\right]$-tyrosine $\left(0.615 \mu \mathrm{mol} \cdot \mathrm{kg}^{-1}\right)$, after which a continuous L-[ring- ${ }^{2} \mathrm{H}_{5}$-phenylalanine $\left(0.050 \pm 0.000 \mu \mathrm{mol} \cdot \mathrm{kg}^{-1} \cdot \mathrm{min}^{-1}\right)$ and L-[ring- $3,{ }^{5}{ }^{2} \mathrm{H}_{2}$-tyrosine $(0.015 \pm 0.000$ $\mu \mathrm{mol} \cdot \mathrm{kg}^{-1} \cdot \mathrm{min}^{-1}$ ) intravenous infusion was initiated $(\mathrm{t}=-210 \mathrm{~min})$. After resting in a supine position for $90 \mathrm{~min}$, a second arterialized blood sample was drawn and a muscle biopsy was collected from the vastus lateralis ( $\mathrm{t}=-120 \mathrm{~min}$ ). To determine basal muscle protein synthesis rates, a second muscle biopsy from the same leg was collected $120 \mathrm{~min}$ after the first biopsy. Subsequently, participants received a beverage containing $20 \mathrm{~g}$ of intrinsically L-[1- $\left.{ }^{13} \mathrm{C}\right]$-phenylalanine labeled casein with (Pro $+\mathrm{CHO}$ ) or without (Pro) $60 \mathrm{~g}$ of carbohydrate $(\mathrm{t}=0)$. Arterialized blood samples were drawn at $\mathrm{t}=-90,-60,-30,0,15,30,45,60,75,90,120,150,180,210,240,270$, and 300 . A third and fourth muscle biopsy were collected from the contralateral leg at $t=120$ and $t=300$, respectively, to determine postprandial muscle protein synthesis rates. Blood samples were collected in EDTA containing tubes and centrifuged at $1000 \times g$ for $10 \mathrm{~min}$ at $4^{\circ} \mathrm{C}$ to obtain plasma. Aliquots of plasma were frozen in liquid nitrogen and stored at $-80^{\circ} \mathrm{C}$. Biopsies were collected from the middle region of the vastus lateralis, approximately $15 \mathrm{~cm}$ above the patella and $3 \mathrm{~cm}$ below entry through the fascia, using the percutaneous needle biopsy technique (17). Muscle samples were dissected carefully, freed from any visible non-muscle material, immediately frozen in liquid nitrogen, and stored at $-80^{\circ} \mathrm{C}$ until further analysis. For a schematic representation of the infusion protocol please see Figure 2.1.

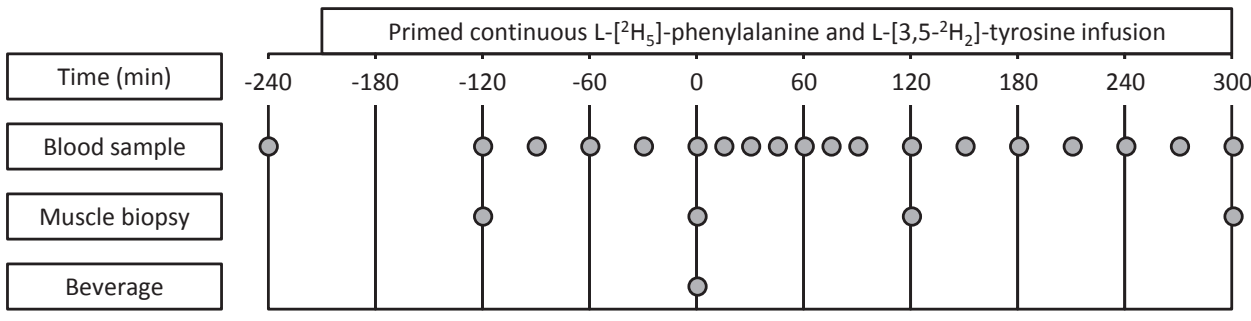

Figure 2.1 | Schematic representation of the infusion protocol

\section{PREPARATION OF INTRINSICALLY LABELED PROTEIN AND BEVERAGE COMPOSITION}

Intrinsically $\mathrm{L}-\left[1-{ }^{13} \mathrm{C}\right]$-phenylalanine labeled casein was prepared by infusing $\mathrm{L}-\left[1-{ }^{13} \mathrm{C}\right]-$ phenylalanine into a lactating Holstein cow, collecting milk, and purifying the casein fraction as described previously (13). The $\mathrm{L}-\left[1-{ }^{13} \mathrm{C}\right]$-phenylalanine enrichment in the casein was 36.2 mole 
percent excess (MPE). The proteins met all chemical and bacteriologic specifications for human consumption. Participants received a beverage containing $20 \mathrm{~g}$ of casein (containing $1.4 \mathrm{~g}$ leucine) with or without $60 \mathrm{~g}$ of carbohydrate $(50 \%$ dextrose monohydrate; Avebe Food, Veendam, the Netherlands, $50 \%$ maltodextrin from starch with a dextrose equivalent of 10-13; AppliChem $\mathrm{GmbH}$, Darmstand, Germany) in a total volume of $350 \mathrm{~mL}$. The beverage was uniformly flavored by adding $2 \mathrm{~mL}$ vanilla flavor (IMCD Benelux N.V., Rotterdam, The Netherlands).

\section{PLASMA ANALYSES}

Plasma glucose and insulin concentrations were analyzed by Dr. Stein und Kollegen Laboratories (Mönchengladbach, Germany) using commercially available kits (GLUC3, Roche, Ref: 05168791 190, and Immunologic, Roche, Ref: 12017547 122, respectively). Plasma amino acid concentrations and enrichments were determined by gas chromatography-mass spectrometry (GC-MS, Agilent 7890A GC/5975C; MSD, Little Falls, DE). Specifically, internal standards of [U- $\left.{ }^{13} \mathrm{C}_{6}\right]$-leucine, [U$\left.{ }^{13} \mathrm{C}_{9}{ }^{15} \mathrm{~N}\right]$-phenylalanine, and $\left[\mathrm{U}-{ }^{13} \mathrm{C}_{9}{ }^{15} \mathrm{~N}\right]$-tyrosine were added to the samples. The plasma was deproteinized on ice with dry 5-sulfosalicylic acid. Free amino acids were purified using cation exchange AG 50W-X8 resin (mesh size: 100-200, ionic form: hydrogen (Bio-Rad Laboratories, Hercules, CA)) columns. The free amino acids were converted to their tert-butyl dimethylsilyl (TBDMS) derivative before analysis by GC-MS. The amino acid concentrations were determined using electron impact ionization by monitoring ions at mass/charge $(\mathrm{m} / \mathrm{z}) 302$ and 308 for unlabeled and $\left[\mathrm{U}-{ }^{13} \mathrm{C}_{6}\right]$-leucine respectively, 336 and 346 for unlabeled and $\left[\mathrm{U}-{ }^{13} \mathrm{C}_{9}{ }^{15} \mathrm{~N}\right]$ phenylalanine respectively, and 466 and 476 for unlabeled and $\left[\mathrm{U}-{ }^{13} \mathrm{C}_{9}{ }^{15} \mathrm{~N}\right]$-tyrosine respectively. The plasma phenylalanine and tyrosine ${ }^{13} \mathrm{C}$ and ${ }^{2} \mathrm{H}$ enrichments were determined using selective ion monitoring at $\mathrm{m} / \mathrm{z} 336,337$, and 341 for unlabeled and labeled $\left(1-{ }^{13} \mathrm{C}\right.$ and ring $\left.^{2} \mathrm{H}_{5}\right)$ phenylalanine respectively, and $\mathrm{m} / \mathrm{z} 466,467,468$, and 470 for unlabeled and labeled $\left(1-{ }^{13} \mathrm{C}\right.$, ring$3,5-{ }^{2} \mathrm{H}_{2}$, and ring $\left.-{ }^{2} \mathrm{H}_{4}\right)$ tyrosine respectively. Standard regression curves were applied from a series of known standard enrichment values against the measured values to assess the linearity of the mass spectrometer and to account for any isotope fractionation which may have occurred during the analysis. Phenylalanine and tyrosine enrichments were corrected for the presence of both the ${ }^{13} \mathrm{C}$ and ${ }^{2} \mathrm{H}$ isotopes.

\section{MUSCLE ANALYSES}

A piece of wet muscle ( 35 mg) was freeze-dried, and collagen, blood, and other non-muscle tissue were removed under a dissecting microscope. The freeze-dried muscle was weighed $(\sim 8$ $\mathrm{mg}$ ) and homogenized in 35 volumes of ice-cold $2 \%$ perchloric acid (PCA). Samples were incubated on ice for 10 minutes. After centrifugation, the supernatant was collected for determination of $\mathrm{L}$-[ring $\left.-{ }^{2} \mathrm{H}_{5}\right]$-phenylalanine and $\mathrm{L}-\left[1-{ }^{13} \mathrm{C}\right]$-phenylalanine enrichments in the muscle free amino acid pool using GC-MS analysis (18). The mixed muscle protein pellet was washed three times with $1 \mathrm{~mL}$ of ice-cold $2 \%$ PCA and hydrolyzed in $3 \mathrm{~mL}$ of $6 \mathrm{M} \mathrm{HCl}$ overnight at $120^{\circ} \mathrm{C}$. The free amino acids were then dissolved in $50 \%$ acetic acid solution and passed over cation exchange AG 50W-X8 resin (mesh size: 100-200, ionic form: hydrogen (Bio-Rad Laboratories, Hercules, CA)) columns. The amino acids were eluted with $2 \mathrm{M} \mathrm{NH}_{4} \mathrm{OH}$ and divided over 2 vials for separate measurements of $\mathrm{L}-\left[1-{ }^{13} \mathrm{C}\right]$-phenylalanine and $\mathrm{L}$-[ring- $\left.{ }^{2} \mathrm{H}_{5}\right]$-phenylalanine enrichments in mixed muscle protein. To determine the L-[ring- $\left.{ }^{2} \mathrm{H}_{5}\right]$-phenylalanine enrichment of mixed muscle protein, the purified amino acids were derivatized into their TBDMS derivatives with MTBSTFA before the ratios of labeled to unlabeled derivatives were determined by GC-MS. To determine the $\mathrm{L}-\left[1-{ }^{13} \mathrm{C}\right]-$ phenylalanine enrichment of mixed muscle protein, the purified amino acids were derivatized into 
their $\mathrm{N}(\mathrm{O}, \mathrm{S})$-ethoxycarbonyl ethyl ester derivatives with ethyl chloroformate (ECF). The derivatives were then measured by gas chromatography-combustion-isotope ratio mass spectrometry (GC-CIRMS, Finnigan MAT 253, Bremen, Germany) using an HP Ultra I GC-column (no. 19091A-112; Hewlett-Packard, Palo Alto, CA), GC Isolink, and monitoring of ion masses 44 and 45 . By establishing the relation between the enrichment of a series of $\mathrm{L}-\left[1-{ }^{13} \mathrm{C}\right]$-phenylalanine standards of variable enrichments and the enrichments of the $\mathrm{N}(\mathrm{O}, \mathrm{S})$-ethoxycarbonyl ethyl esters of these standards, the mixed muscle protein-bound enrichment of phenylalanine was determined. Standard regression curves were applied to assess the linearity of the mass spectrometer and to control for the loss of tracer.

\section{CALCULATIONS}

Ingestion of $\mathrm{L}-\left[1-{ }^{13} \mathrm{C}\right]$-phenylalanine labeled protein, intravenous infusion of $\mathrm{L}$-[ring- $\left.{ }^{2} \mathrm{H}_{5}\right]-$ phenylalanine and L-[ring-3,5- ${ }^{2} \mathrm{H}_{2}$ ]-tyrosine, and arterialized blood sampling were used to assess whole-body amino acid kinetics in non-steady state conditions. Total, exogenous, and endogenous rate of appearance $\left(R_{a}\right)$ and plasma availability of dietary phenylalanine (i.e. the fraction of dietary phenylalanine that appeared in the systemic circulation, Phe $_{\text {plasma }}$ ) were calculated using modified Steele's equations $(19,20)$. These parameters were calculated as follows:

Total $R_{a}=\frac{F_{i v}-\left[p V \times C(t) \times \frac{d E_{i v}}{d t}\right]}{E_{i v}(t)}$

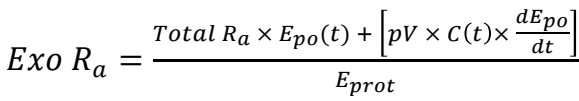

Endo $R_{a}=$ Total $R_{a}-$ Exo $R_{a}-F_{\text {iv }}$

Phe $_{\text {plasma }}=\left(\frac{A U C_{\text {Exo Ra }}}{\text { Phe }_{\text {prot }}}\right) \times B W \times 100 \%$

where $F_{i v}$ is the intravenous tracer infusion rate $\left(\mu \mathrm{mol} \cdot \mathrm{kg}^{-1} \cdot \mathrm{min}^{-1}\right) \cdot p V\left(0.125 \mathrm{~L} \cdot \mathrm{kg}^{-1}\right)$ is the distribution volume for phenylalanine (19), $C(t)$ is the mean plasma phenylalanine concentration between two consecutive time points, and $d E_{i v} / d t$ represents the time-dependent variations of plasma phenylalanine enrichment derived from the intravenous tracer. $E_{i v}(t)$ is the mean plasma phenylalanine enrichment from the intravenous tracer between two consecutive time points. Exo $R_{a}$ represents the plasma entry rate of dietary phenylalanine. $E_{p o}(t)$ is the mean plasma phenylalanine enrichment for the oral tracer, $d E_{p d} / d t$ represents the time-dependent variations of plasma phenylalanine enrichment derived from the oral tracer, and $E_{\text {prot }}$ is the $\mathrm{L}-\left[1-{ }^{13} \mathrm{C}\right]-$ phenylalanine enrichment in the dietary protein. $A U C_{E x o R a}$ represents the area under curve (AUC) of Exo $R_{a}$, which corresponds to the amount of dietary phenylalanine that appeared in the blood over a $5 \mathrm{~h}$ postprandial period. Phe $e_{\text {prot }}$ is the amount of dietary phenylalanine ingested. $B W$ is the participants' body weight.

Total phenylalanine rate of disappearance $\left(R_{d}\right)$ was calculated by adding the rate of phenylalanine hydroxylation (first step in phenylalanine oxidation) to the rate of phenylalanine utilization for protein synthesis. This parameter is calculated as follows: 
Total $R_{d}=$ Total $R_{a}-p V \times \frac{d C}{d t}$

Phe hydroxylation $=$ Tyr $R_{a} \times \frac{E_{\text {Tyr }}(t)}{E_{\text {Phe }}(t)} \times \frac{\text { Phe } R_{d}}{\left(F_{P h e}+P h e R_{d}\right)}$

Protein synthesis $=$ Total $R_{d}-$ Phe hydroxylation

Phe net balance $=$ Protein synthesis - Endo $R_{a}$

where Tyr $R_{a}$ is the total rate of appearance based on the L-[ring-3, $\left.5-{ }^{2} \mathrm{H}_{2}\right]$-tyrosine infusion and plasma enrichment. $E_{\text {Tyr }}(t)$ and $E_{\text {Phe }}(t)$ represent the mean plasma L-[ring- ${ }^{2} \mathrm{H}_{4}$ ]-tyrosine and L-[ring${ }^{2} \mathrm{H}_{5}$ ]-phenylalanine enrichment between 2 consecutive time points, respectively. $F_{\text {Phe }}$ is the intravenous infusion rate of $\mathrm{L}-\left[\right.$ ring $\left.-{ }^{2} \mathrm{H}_{5}\right]$-phenylalanine $\left(\mu \mathrm{mol} \cdot \mathrm{kg}^{-1} \cdot \mathrm{min}^{-1}\right)$.

Mixed muscle protein fractional synthetic rate (FSR) was calculated using the standard precursorproduct equation:

$F S R=\frac{\Delta E_{p}}{E_{\text {precursor }} \cdot t} \cdot 100 \%$

where $\Delta E_{p}$ is the increment in mixed muscle protein-bound L-[1- $\left.{ }^{13} \mathrm{C}\right]$-phenylalanine or L-[ring- $\left.{ }^{2} \mathrm{H}_{5}\right]$ phenylalanine after an incorporation period (TTR), $E_{\text {precursor }}$ is the average plasma L- $\left[1-{ }^{13} \mathrm{C}\right]-$ phenylalanine or plasma L-[ring- ${ }^{2} \mathrm{H}_{5}$ ]-phenylalanine enrichment during that incorporation period (TTR), and $t$ is the incorporation period (h). For basal FSR, muscle biopsies at -120 and 0 min were used, and for postprandial FSR, biopsies at 0,120 , and 300 were used to calculate the early "peak" FSR (0-2h), the late response (2-5h), and the aggregate response (0-5h).

\section{STATISTICS}

All data are expressed as mean \pm SEM. Incremental area under curve (iAUC), peak value, and time to peak were calculated for all plasma time curves. A Univariate analysis of variance (ANOVA) with age and treatment as factors and oral glucose insulin sensitivity (OGIS) as co-variate was applied to detect differences between groups. For the muscle data a linear mixed-model ANOVA with age, treatment, time, and their interactions as fixed factors and OGIS as co-variate was used to detect differences between treatments (Pro and Pro $+\mathrm{CHO}$ ) and age (Young and Old) over time. Statistical significance was set at $P<0.05$. All calculations were performed using IBM SPSS Statistics (version 20). 


\section{RESULTS}

\section{PLASMA ANALYSES}

Plasma glucose concentrations increased following Pro+CHO ingestion to a greater extent in the old when compared with the young, whereas glucose concentrations in the Pro groups remained at baseline values (age $\times$ treatment interaction; $P<0.05$; Figure 2.2A). Plasma insulin concentrations increased following beverage ingestion in all groups, but peak values were 4.9 fold higher in the Pro $+\mathrm{CHO}$ condition when compared with the Pro condition $(P<0.001$; Figure $2.2 \mathrm{~B})$. Also, in the Pro $+\mathrm{CHO}$ treatment groups insulin concentrations increased to a greater extent in the old when compared with the young (age $\times$ treatment interaction; $P<0.05$ ).

A

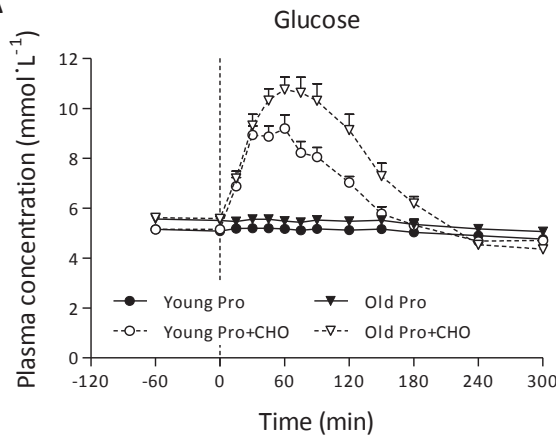

B

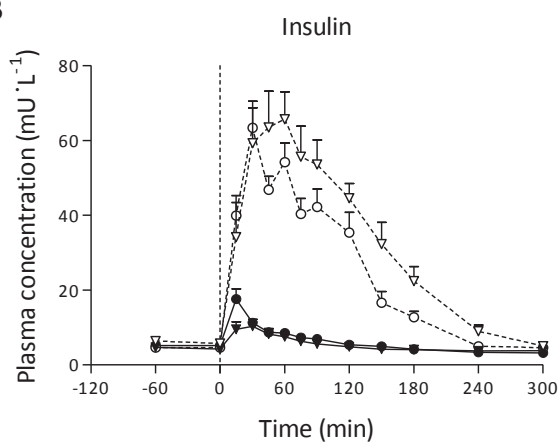

Figure 2.2 $\mid$ Mean ( \pm SEM) plasma glucose $(A)$ and insulin (B) concentrations (mmol. $\mathrm{L}^{-1}$ and $\mathrm{mU} \cdot \mathrm{L}^{-1}$, respectively) in young $(n=24)$ and older $(n=25)$ subjects during the fasting period and following ingestion of $20 \mathrm{~g}$ casein with (Pro+CHO) or without (Pro) $60 \mathrm{~g}$ carbohydrates. Glucose: iAUC age $\times$ treatment interaction $(P=0.022)$, peak value age $\times$ treatment interaction $(P=0.030)$. Insulin: iAUC age $\times$ treatment interaction $(P=0.039)$, peak value treatment effect $(P<0.001)$.

Plasma phenylalanine, tyrosine, and leucine concentrations are shown in Figure 2.3. Amino acid concentrations increased following beverage ingestion in all groups. Phenylalanine and tyrosine concentrations were higher $(P<0.05)$ and there was a trend for leucine concentrations to be higher $(P=0.10)$ in older subjects irrespective of the treatment. Carbohydrate co-ingestion significantly reduced plasma amino acid concentrations in both age groups $(P<0.001)$. However, carbohydrate co-ingestion reduced phenylalanine peak values to a greater extent in the young when compared with the old (age $\times$ treatment interaction; $P<0.05$ ). 
A

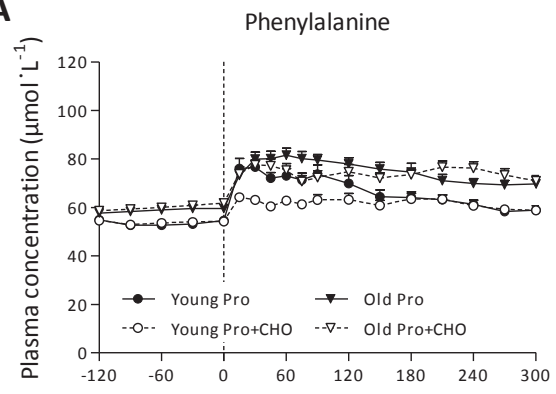

C

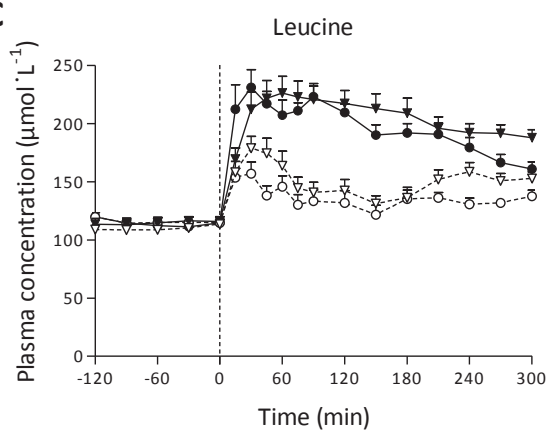

B

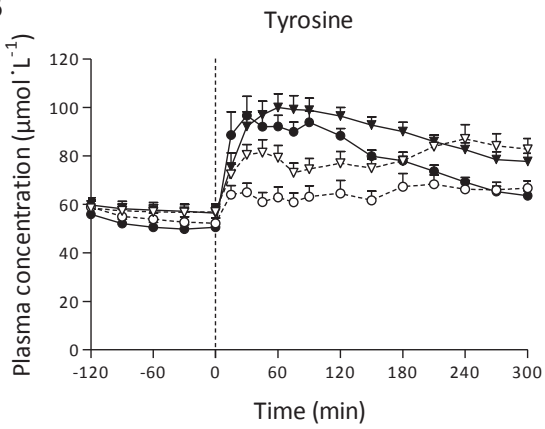

Figure 2.3 | Mean ( \pm SEM) plasma phenylalanine (A), tyrosine (B), and leucine $(C)$ concentrations $\left(\mu \mathrm{mol} \cdot \mathrm{L}^{-1}\right)$ in young $(n=24)$ and older $(n=25)$ subjects during the fasting period and following ingestion of $20 \mathrm{~g}$ casein with (Pro+CHO) or without (Pro) $60 \mathrm{~g}$ carbohydrates. Phenylalanine: iAUC age effect $(P=0.017)$, iAUC treatment effect $(P=0.010)$, peak value age $\times$ treatment interaction $(P=0.044)$. Tyrosine: iAUC age effect $(P=0.022)$, iAUC treatment effect $(P<0.001)$. Leucine: iAUC age effect $(P=0.100)$, iAUC treatment effect $(P<0.001)$.

Figure 2.4 shows the plasma L-[ring- ${ }^{2} \mathrm{H}_{5}$ ]-phenylalanine enrichments (from infused tracer) and the plasma L- $\left[1-{ }^{13} \mathrm{C}\right]$-phenylalanine enrichments (from ingested tracer). L-[ring- $\left.{ }^{2} \mathrm{H}_{5}\right]$-phenylalanine enrichments were higher in the older participants when compared with the young $(P=0.001)$. The L-[ring- ${ }^{2} \mathrm{H}_{5}$-phenylalanine enrichments remained stable in all groups during the post-absorptive period. After ingestion of the beverage a transient decline in $\mathrm{L}$-[ring- $\left.{ }^{2} \mathrm{H}_{5}\right]$-phenylalanine enrichments was observed in all groups. This observed decline in plasma L-[ring- $\left.{ }^{2} \mathrm{H}_{5}\right]-$ phenylalanine enrichments was greater in the old when compared with the young $(P<0.01)$. Plasma L-[1 $\left.-{ }^{13} \mathrm{C}\right]$-phenylalanine enrichments (iAUC and peak values) did not differ between groups. However, carbohydrate co-ingestion, regardless of age, delayed the time to peak $(P<0.001)$. 
A

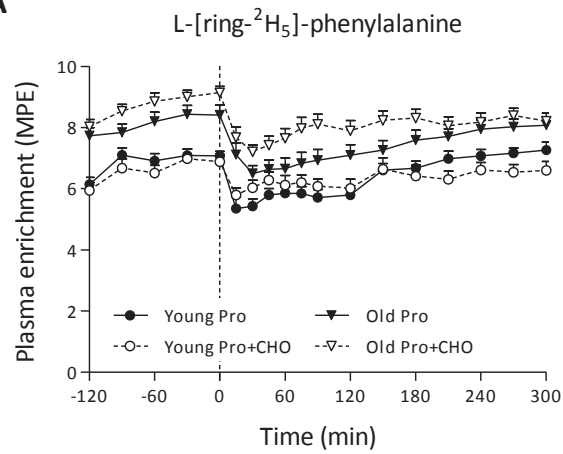

B

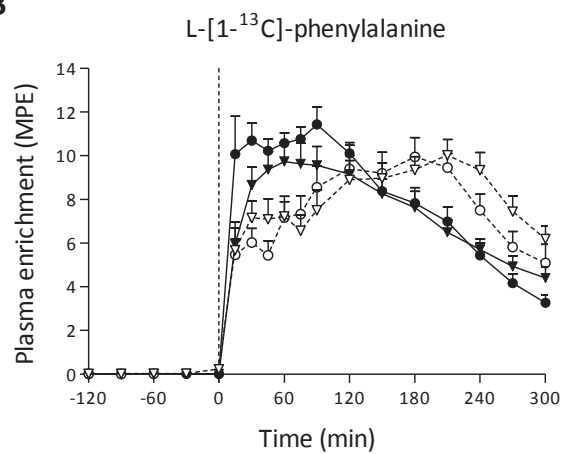

Figure 2.4 | Mean ( \pm SEM) plasma L-[ring- $\left.{ }^{2} \mathrm{H}_{5}\right]$-phenylalanine $(\mathrm{A})$ and L-[1-13 C]-phenylalanine (B) enrichments (mole percent excess, MPE) in young $(n=24)$ and older $(n=25)$ subjects during the fasting period and following ingestion of $20 \mathrm{~g}$ casein with (Pro $+\mathrm{CHO})$ or without (Pro) $60 \mathrm{~g}$ carbohydrates. L-[ring- ${ }^{2} \mathrm{H}_{5}$-phenylalanine: iAUC age effect $(P=0.006)$, nadir value $(P=0.001)$. L- $\left[1-{ }^{13} \mathrm{C}\right]$-phenylalanine: time to peak treatment effect $(P<0.001)$.

\section{WHOLE-BODY PHENYLALANINE KINETICS}

Whole-body phenylalanine kinetics are presented in Figure 2.5. Exogenous phenylalanine rates of appearance (i.e., the rate at which dietary protein-derived phenylalanine enters the circulation) tended to be lower in elderly when compared with the young $(P=0.09$; Figure $2.5 \mathrm{~A})$. Furthermore, carbohydrate co-ingestion reduced the peak rates $(P<0.05)$ and delayed the time to peak $(P=0.001)$ in both age groups. The amount of dietary protein-derived phenylalanine that appeared in the circulation over the $5 \mathrm{~h}$ postprandial period was lower in the old when compared with the young, with no significant differences between conditions ( $73 \pm 2$ vs $76 \pm 3$ and $62 \pm 4$ vs $63 \pm 2 \%$ following Pro vs Pro $+\mathrm{CHO}$ in the young and old, respectively; age effect; $P<0.01$, treatment effect; $P=0.20$ ). Endogenous phenylalanine rates of appearance (i.e., the rate at which phenylalanine derived from whole-body protein breakdown enters the circulation) were higher in the young when compared with the old $(P<0.01 ;$ Figure 2.5B). Endogenous phenylalanine rates of appearance were reduced after beverage ingestion, but to a greater extent in the young than in the old $(P=0.001)$ irrespective of treatment. Total phenylalanine rates of appearance were lower in the old when compared with the young $(P<0.01)$. Carbohydrate co-ingestion reduced total phenylalanine rates of appearance in both age groups $(P<0.05$; Figure $2.5 C)$. Total phenylalanine rates of disappearance were lower in elderly $(P<0.01)$ with no differences between treatments (Figure $2.5 \mathrm{D})$. 
A

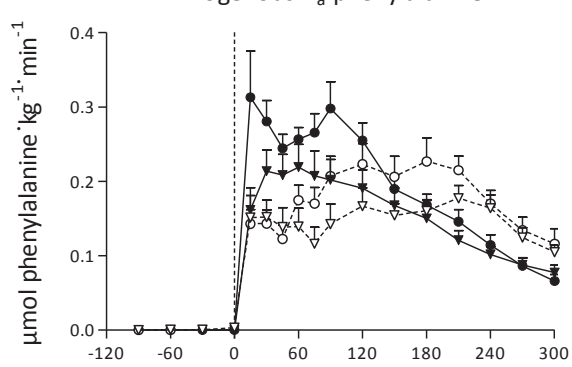

C

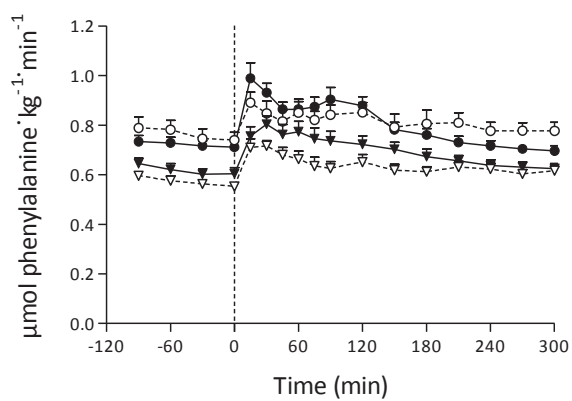

B Endogenous $R_{a}$ phenylalanine

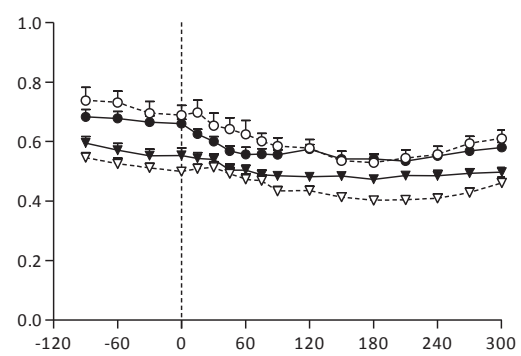

D

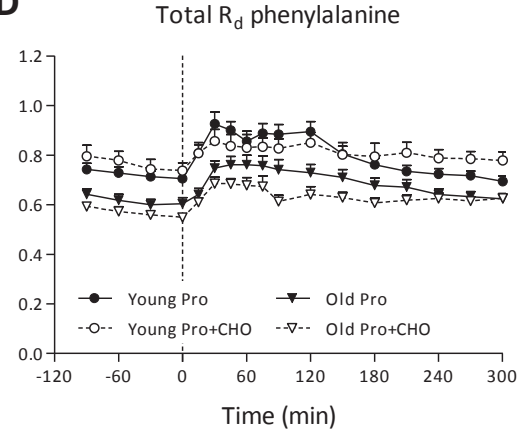

Figure 2.5 | Whole-body phenylalanine kinetics. Mean ( \pm SEM) exogenous rate of appearance $\left(R_{a}, A\right)$, endogenous $R_{a}(B)$, total $R_{a}(C)$, and total rate of disappearance $\left(R_{d}, D\right)\left(\mu\right.$ mol phenylalanine $\left.\cdot \mathrm{kg}^{-1} \cdot \mathrm{min}^{-1}\right)$ in young $(n=24)$ and older $(n=25)$ subjects during the fasting period and following ingestion of $20 \mathrm{~g}$ casein with (Pro+CHO) or without (Pro) $60 \mathrm{~g}$ carbohydrates. Exogenous rate of appearance: iAUC age effect $(P=0.086)$, peak value treatment effect $(P=0.031)$, time to peak treatment effect $(P=0.001)$. Endogenous rate of appearance: iAUC age effect $(P=0.001)$, nadir value age effect $(P=0.009)$. Total rate of appearance: peak value age effect $(P=0.009)$, peak value treatment effect $(P=0.039)$. Total rate of disappearance: peak value age effect $(P=0.006)$.

Post-absorptive and postprandial whole-body protein metabolism are shown in Figure 2.6. During the post-absorptive period (Figure 2.6A), whole-body protein breakdown, synthesis, and oxidation were lower in the elderly when compared with the young $(P<0.005)$. However, whole-body net protein balance was significantly higher in the elderly $(P<0.001)$. During the postprandial period (Figure 2.6B), both protein breakdown and oxidation were lower in the $\mathrm{Pro}+\mathrm{CHO}$ groups when compared with the Pro groups $(P<0.05)$ and protein synthesis was unaffected. No significant differences were observed in net protein balance between groups. 
A

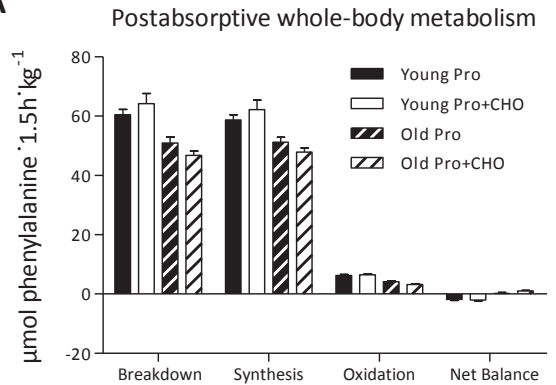

B

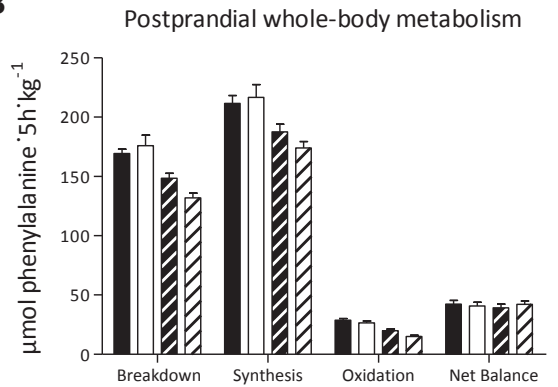

Figure 2.6 | Whole-body protein metabolism during the post-absorptive (A) and postprandial (B) state in young ( $n=24)$ and older $(n=24)$ subjects following Pro or Pro+CHO ingestion. Values represent mean \pm SEM. Post-absorptive: breakdown age effect $(P=0.001)$, synthesis age effect $(P=0.004)$, oxidation age effect $(P<0.001)$, net balance age effect $(P<0.001)$. Postprandial: breakdown treatment effect $(P=0.027)$, oxidation treatment effect $(P<0.007)$.

\section{MUSCLE ANALYSES}

Muscle tissue-free L-[ring- $\left.{ }^{2} \mathrm{H}_{5}\right]$-phenylalanine and $\mathrm{L}-\left[1-{ }^{13} \mathrm{C}\right]$-phenylalanine enrichments are presented in Table 2.2. The muscle-free $\mathrm{L}$-[ring ${ }^{2} \mathrm{H}_{5}$-phenylalanine enrichments were higher in older participants when compared with the young $(P<0.001)$. The muscle-free $\mathrm{L}-\left[1-{ }^{13} \mathrm{C}\right]-$ phenylalanine enrichments were higher in the Pro than in the Pro+CHO groups at $2 \mathrm{~h}$. At $5 \mathrm{~h}$, the L$\left[1-{ }^{13} \mathrm{C}\right]$-phenylalanine enrichments were higher in the Pro+CHO when compared with the Pro groups (treatment $\times$ time interaction; $P<0.05$ ). This is reflective of the observed delay in digestion and absorption when carbohydrates are co-ingested with protein.

Table 2.2 | Muscle tissue-free enrichments

\begin{tabular}{|c|c|c|c|c|c|}
\hline \multicolumn{3}{|c|}{$-2 h$} & $\mathbf{O h}$ & $2 \mathrm{~h}$ & $5 \mathrm{~h}$ \\
\hline \multirow{4}{*}{$\begin{array}{l}\left.\text { L-[ring }-{ }^{2} \mathrm{H}_{5}\right]- \text { phenylalanine } \\
\text { (MPE) }\end{array}$} & Young Pro $(n=12)$ & $3.89 \pm 0.26$ & $4.42 \pm 0.15$ & $4.07 \pm 0.14$ & $4.55 \pm 0.11$ \\
\hline & Young Pro $+\mathrm{CHO}(n=12)$ & $3.50 \pm 0.14$ & $4.28 \pm 0.16$ & $4.28 \pm 0.16$ & $4.37 \pm 0.13$ \\
\hline & Old Pro $(n=12)$ & $4.08 \pm 0.20 *$ & $5.57 \pm 0.25 *$ & $4.88 \pm 0.20 *$ & $5.85 \pm 0.25 *$ \\
\hline & Old Pro $+\mathrm{CHO}(n=12)$ & $4.65 \pm 0.21 *$ & $5.91 \pm 0.25 *$ & $5.43 \pm 0.16 *$ & $5.97 \pm 0.33 *$ \\
\hline \multirow{4}{*}{$\begin{array}{l}\mathrm{L}-\left[1-{ }^{13} \mathrm{C}\right] \text {-phenylalanine } \\
\text { (MPE) }\end{array}$} & Young Pro $(n=12)$ & $0.16 \pm 0.04$ & $0.12 \pm 0.04$ & $5.97 \pm 0.43$ & $3.08 \pm 0.24$ \\
\hline & Young Pro $+\mathrm{CHO}(n=12)$ & $0.11 \pm 0.02$ & $0.13 \pm 0.03$ & $4.98 \pm 0.61$ & $3.69 \pm 0.49$ \\
\hline & Old Pro $(n=12)$ & $0.19 \pm 0.04$ & $0.16 \pm 0.03$ & $5.64 \pm 0.61$ & $3.67 \pm 0.30$ \\
\hline & Old Pro+CHO $(n=12)$ & $0.15 \pm 0.04$ & $0.19 \pm 0.04$ & $5.02 \pm 0.73$ & $5.30 \pm 0.54$ \\
\hline
\end{tabular}

Values are means $\pm \mathrm{SEM}$. MPE, mole percent excess. Data were analyzed by linear mixed-model ANOVA. L-[ring- $\left.{ }^{2} \mathrm{H}_{5}\right]-$ phenylalanine: age effect $\left({ }^{*} P<0.001\right)$, treatment effect $(P=0.200)$, time effect $(P=0.470)$. L-[1-13 $\left.C\right]$-phenylalanine: treatment $\times$ time interaction $(P=0.026)$, age effect $(P=0.097)$, treatment effect $(P=0.229)$, time effect $(P=0.001)$.

Mixed muscle protein FSR, calculated based on the plasma precursor pool, is presented in Figure 2.7A. The early $(0-2 \mathrm{~h})$ postprandial muscle protein FSR was significantly higher when compared with post-absorptive muscle protein FSR in the young but not in the older subjects, regardless of treatment (age $\times$ time interaction; $P=0.011$ ). The cumulative $(0-5 \mathrm{~h})$ postprandial muscle protein synthetic response was significantly higher when compared with post-absorptive muscle protein synthesis rates $(P=0.001)$, but no differences were observed between groups ( $P=0.19$ and $P=0.21$ 
for age and treatment, respectively). Similar mixed muscle protein synthesis rates were observed using the muscle-free enrichments as precursor pool (data not shown).

Mixed muscle protein-bound L-[1-13 C]-phenylalanine enrichments (Figure 2.7B) increased over time $(P<0.001)$, but no differences were observed between groups $(P=0.27$ and $P=0.34$ for age and treatment, respectively). The FSR of dietary protein-derived amino acids into muscle protein over the $0-5 \mathrm{~h}$ postprandial period was similar for the young $\left(0.050 \pm 0.006\right.$ vs $\left.0.051 \pm 0.005 \% \cdot \mathrm{h}^{-1}\right)$ and the old $\left(0.048 \pm 0.006\right.$ vs $\left.0.051 \pm 0.007 \% \cdot h^{-1}\right)$ in the Pro vs Pro $+\mathrm{CHO}$ conditions, respectively $(P>0.05)$.

A

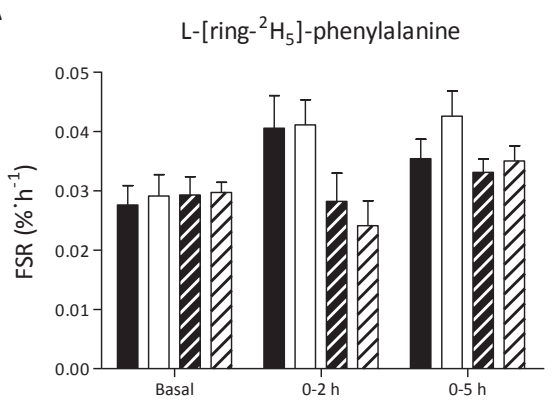

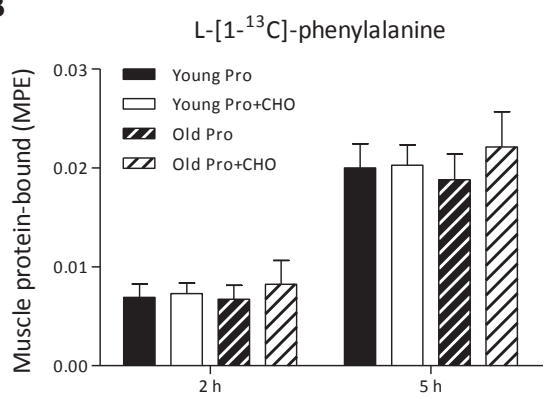

Figure 2.7 | Mean ( \pm SEM) mixed muscle protein fractional synthetic rates (FSR, \% $\left.\cdot \mathrm{h}^{-1}, \mathrm{~A}\right)$ and mixed muscle proteinbound L-[1-13 $\mathrm{C}]$-phenylalanine enrichments (mole percent excess, MPE, B) in young $(n=24)$ and older $(n=24)$ subjects during the fasting (basal) period and following ingestion of $20 \mathrm{~g}$ casein with (Pro+CHO) or without (Pro) $60 \mathrm{~g}$ carbohydrates. A: age $\times$ time interaction $(P=0.010)$, pre-post effect $(P=0.001)$, age effect $(P=0.190)$, treatment effect $(P=0.210)$. B: time effect $(P<0.001)$. 


\section{Discussion}

We demonstrate for the first time that carbohydrate co-ingestion with protein delays protein digestion and absorption without modulating the postprandial muscle protein synthetic response in healthy young and older men. Interestingly, a temporal discordance in the postprandial stimulation of muscle protein synthesis rates was observed between the young and older population.

The ingested protein was properly digested and absorbed as indicated by the rapid increase in plasma amino acid concentrations (Figure 2.3). Consistent with previous work (21-23), carbohydrate co-ingestion resulted in an attenuated rise in plasma phenylalanine concentrations in both the young and older men. This implies that carbohydrate co-ingestion either reduced the rate of phenylalanine appearance in the circulation or enhanced the rate of phenylalanine disappearance from the circulation. The combination of intravenous stable isotope labeled amino acid infusion with the ingestion of intrinsically labeled protein allowed us to determine that the attenuated rise in plasma amino acid concentrations following carbohydrate co-ingestion was attributed to a delay in protein digestion and absorption (Figure 2.4B and 2.5A). This delay is likely attributed to the greater caloric density of the protein plus carbohydrate-containing beverage that may have reduced the rate of gastric emptying (24).

It has been well established that older individuals have a smaller plasma volume per $\mathrm{kg}$ body weight when compared with younger controls $(11,12)$. In line with this, we observed that plasma L-[ring- $\left.{ }^{2} \mathrm{H}_{5}\right]$-phenylalanine enrichments were higher in older when compared with young men. Similarly, postprandial aminoacidemia was greater in older men, despite consuming the same amount $(20 \mathrm{~g})$ of dietary protein as the young men. In contrast, plasma L- $\left[1-{ }^{13} \mathrm{C}\right]$-phenylalanine enrichments did not differ between age groups, indicating that less of the ingested proteinderived amino acids had entered the circulation in the older men. Indeed, the appearance of dietary protein-derived amino acids into the circulation (exogenous phenylalanine appearance rates) tended to be lower in old when compared with young men $(P=0.09)$, with less of the dietary protein-derived phenylalanine appearing into the circulation in the old $(62 \pm 2 \%)$ when compared with the young $(74 \pm 2 \%)$ during the $5 \mathrm{~h}$ postprandial period. These data seem to be at odds with previous work from our group comparing protein digestion and absorption kinetics and subsequent plasma amino acid availability between young and older individuals (11, 12). However, in the present study we selected older, more sedentary individuals $(75 \pm 1 \mathrm{y})$. Consequently, the presented data suggest that protein digestion and absorption is impaired and/or splanchnic extraction is increased at a more advanced age.

The postprandial rise in circulating insulin might facilitate muscle protein anabolism by suppressing proteolysis (25) and enhancing blood flow (nutritive flow) and microvascular perfusion (capillary recruitment) thereby increasing amino acid availability in skeletal muscle tissue $(26,27)$. In the present study, carbohydrate co-ingestion further enhanced the postprandial rise in circulating insulin in both age groups (Figure 2.2B). However, this did not further augment wholebody net protein balance or increase postprandial muscle protein synthesis rates in either the young or older men. A moderate rise in circulating insulin (up to $\sim 30 \mathrm{mU} \cdot \mathrm{L}^{-1}$ ) may already be sufficient to maximize postprandial anabolism (28). Interestingly, the reduced insulin sensitivity in the older group was accompanied by a greater postprandial insulin release when compared with the young men (Figure 2.2B). This greater postprandial insulin release may represent a compensatory mechanism for the blunted postprandial muscle protein synthetic and/or proteolytic response due to insulin resistance in the older population (29). 
In line with previous findings (30), we demonstrate that post-absorptive muscle protein synthesis rates do not differ between healthy young and older men (Figure 2.7A). When the muscle protein synthetic response is assessed over the entire $5 \mathrm{~h}$ postprandial period, we observed that both the Pro and the Pro+CHO conditions resulted in similar increases in muscle protein synthesis rates in both the young and old men (Figure 2.7A). Some previous studies have reported age-related differences in postprandial muscle protein synthesis rates $(1,31)$. The apparent discrepancy is likely attributed to the fact that these studies assessed postprandial muscle protein synthesis rates during the early postprandial stages. In agreement, the muscle protein synthetic responses were significantly elevated from basal values in the young men only when assessed over the early $2 \mathrm{~h}$ postprandial phase (Figure 2.7A). Such an observation seems to agree with previous work that demonstrated a delay or lag period prior to a robust increase in the stimulation of muscle protein synthesis rates following amino acid ingestion during postexercise recovery in older versus young men (32). The delay in the postprandial rise in muscle protein synthesis rates may be attributed to the delay in protein digestion and absorption rates and subsequent reduction in dietary proteinderived plasma amino acid availability that was observed during the initial postprandial phase in the older when compared with the young men. However, regardless of condition, there were no significant differences in the mixed muscle protein synthetic response over the entire $5 \mathrm{~h}$ postprandial phase between the age groups (Figure 2.7A).

The use of intrinsically L- $\left[1-{ }^{13} \mathrm{C}\right]$-phenylalanine-labeled protein allowed us to assess the metabolic fate of dietary protein-derived amino acids. Skeletal muscle protein-bound L-[1- $\left.{ }^{13} \mathrm{C}\right]$-phenylalanine enrichments increased over time, with no differences being observed following co-ingestion of carbohydrates (Figure 2.7B). These data provide further support that carbohydrate co-ingestion does not augment the postprandial muscle protein synthetic response to protein ingestion. These findings are in line with previous work from our group $(21,22)$ as well as others $(23,33,34)$ in various settings in both young and older men. Some researchers have reported gender-based differences in basal muscle protein synthesis rates or in the muscle protein synthetic response to amino acid administration (35-38), others have been unable to detect such differences (39-42). The present proof-of-principle study shows that carbohydrate co-ingestion delays dietary protein digestion and absorption and does not further augment muscle protein synthesis rates. Though there is no specific rationale to assume that this response is gender specific, more research is required to assess potential gender-based differences in postprandial protein metabolism. The present findings extend on previous work in this area by showing that carbohydrate co-ingestion delays protein digestion and absorption and, as such, may even compromise postprandial muscle protein anabolism. These findings are of considerable relevance and show that co-ingesting carbohydrates with an adequate protein dose (i.e., $20 \mathrm{~g}$ ) is not required to maximize postprandial muscle protein accretion in older men. Nutritional supplements designed to support healthy aging and/or prevent muscle loss during a period of disuse generally contain a combination of all macronutrients. However, with the overall restriction of total energy intake and the need to maintain or even increase dietary protein intake, nutritional support should focus on providing high quality protein without adding considerable amounts of carbohydrate.

In conclusion, carbohydrate co-ingestion with protein delays dietary protein digestion and absorption, and does not improve postprandial muscle protein accretion in healthy young or older men. These findings indicate that dietary protein supplementation does not require co-ingestion of large amounts of carbohydrate to optimize postprandial muscle protein accretion. 


\section{REFERENCES}

1. Cuthbertson D, Smith K, Babraj J, Leese G, Waddell T, Atherton P, Wackerhage H, Taylor PM, Rennie MJ. Anabolic signaling deficits underlie amino acid resistance of wasting, aging muscle. Faseb J 2005;19(3):422-4.

2. Durham WJ, Casperson SL, Dillon EL, Keske MA, Paddon-Jones D, Sanford AP, Hickner RC, Grady JJ, SheffieldMoore M. Age-related anabolic resistance after endurance-type exercise in healthy humans. Faseb J 2010;24(10):4117-27.

3. Fujita S, Glynn EL, Timmerman KL, Rasmussen BB, Volpi E. Supraphysiological hyperinsulinaemia is necessary to stimulate skeletal muscle protein anabolism in older adults: evidence of a true age-related insulin resistance of muscle protein metabolism. Diabetologia 2009;52(9):1889-98.

4. Guillet C, Prod'homme M, Balage M, Gachon P, Giraudet C, Morin L, Grizard J, Boirie Y. Impaired anabolic response of muscle protein synthesis is associated with $\mathrm{S} 6 \mathrm{~K} 1$ dysregulation in elderly humans. Faseb J 2004;18(13):1586-7.

5. Kumar V, Selby A, Rankin D, Patel R, Atherton P, Hildebrandt W, Williams J, Smith K, Seynnes O, Hiscock N, et al. Age-related differences in the dose-response relationship of muscle protein synthesis to resistance exercise in young and old men. J Physiol 2009;587(Pt 1):211-7.

6. Volpi E, Mittendorfer B, Rasmussen BB, Wolfe RR. The response of muscle protein anabolism to combined hyperaminoacidemia and glucose-induced hyperinsulinemia is impaired in the elderly. J Clin Endocrinol Metab 2000;85(12):4481-90.

7. Burd NA, Gorissen SH, van Loon LJ. Anabolic resistance of muscle protein synthesis with aging. Exercise and sport sciences reviews 2013.

8. Boirie Y, Gachon P, Beaufrere B. Splanchnic and whole-body leucine kinetics in young and elderly men. Am J Clin Nutr 1997;65(2):489-95.

9. Gaudichon C, Mahe S, Benamouzig R, Luengo C, Fouillet H, Dare S, Van Oycke M, Ferriere F, Rautureau J, Tome D. Net postprandial utilization of [15N]-labeled milk protein nitrogen is influenced by diet composition in humans. J Nutr 1999;129(4):890-5.

10. Fouillet H, Gaudichon C, Mariotti F, Bos C, Huneau JF, Tome D. Energy nutrients modulate the splanchnic sequestration of dietary nitrogen in humans: a compartmental analysis. Am J Physiol Endocrinol Metab 2001;281(2):E248-60.

11. Koopman R, Walrand S, Beelen M, Gijsen AP, Kies AK, Boirie Y, Saris WH, van Loon LJ. Dietary protein digestion and absorption rates and the subsequent postprandial muscle protein synthetic response do not differ between young and elderly men. J Nutr 2009;139(9):1707-13.

12. Pennings B, Koopman R, Beelen M, Senden JM, Saris WH, van Loon LJ. Exercising before protein intake allows for greater use of dietary protein-derived amino acids for de novo muscle protein synthesis in both young and elderly men. Am J Clin Nutr 2011;93(2):322-31.

13. Pennings B, Pellikaan WF, Senden JM, van Vuuren AM, Sikkema J, van Loon LJ. The production of intrinsically labeled milk and meat protein is feasible and provides functional tools for human nutrition research. J Dairy Sci 2011;94(9):4366-73.

14. van Loon LJ, Boirie Y, Gijsen AP, Fauquant J, de Roos AL, Kies AK, Lemosquet S, Saris WH, Koopman R. The production of intrinsically labeled milk protein provides a functional tool for human nutrition research. J Dairy Sci 2009;92(10):4812-22.

15. Alberti KG, Zimmet PZ. Definition, diagnosis and classification of diabetes mellitus and its complications. Part 1: diagnosis and classification of diabetes mellitus provisional report of a WHO consultation. Diabet Med 1998;15(7):539-53.

16. Abumrad NN, Rabin D, Diamond MP, Lacy WW. Use of a heated superficial hand vein as an alternative site for the measurement of amino acid concentrations and for the study of glucose and alanine kinetics in man. Metabolism 1981;30(9):936-40.

17. Bergstrom J. Percutaneous needle biopsy of skeletal muscle in physiological and clinical research. Scand J Clin Lab Invest 1975;35(7):609-16.

18. Wall BT, Hamer HM, de Lange A, Kiskini A, Groen BB, Senden JM, Gijsen AP, Verdijk LB, van Loon LJ. Leucine coingestion improves post-prandial muscle protein accretion in elderly men. Clin Nutr 2012.

19. Boirie Y, Gachon P, Corny S, Fauquant J, Maubois JL, Beaufrere B. Acute postprandial changes in leucine metabolism as assessed with an intrinsically labeled milk protein. Am J Physiol 1996;271(6 Pt 1):E1083-91.

20. Dangin M, Guillet C, Garcia-Rodenas C, Gachon P, Bouteloup-Demange C, Reiffers-Magnani K, Fauquant J, Ballevre $\mathrm{O}$, Beaufrere $\mathrm{B}$. The rate of protein digestion affects protein gain differently during aging in humans. J Physiol 2003;549(Pt 2):635-44.

21. Hamer HM, Wall BT, Kiskini A, de Lange A, Groen BB, Bakker JA, Gijsen AP, Verdijk LB, van Loon LJ. Carbohydrate co-ingestion with protein does not further augment post-prandial muscle protein accretion in older men. Nutr Metab (Lond) 2013;10(1):15.

22. Koopman R, Beelen M, Stellingwerff T, Pennings B, Saris WH, Kies AK, Kuipers H, van Loon LJ. Coingestion of carbohydrate with protein does not further augment postexercise muscle protein synthesis. Am J Physiol Endocrinol Metab 2007;293(3):E833-42.

23. Staples AW, Burd NA, West DW, Currie KD, Atherton PJ, Moore DR, Rennie MJ, Macdonald MJ, Baker SK, Phillips SM. Carbohydrate does not augment exercise-induced protein accretion versus protein alone. Med Sci Sports Exerc 2011;43(7):1154-61. 
24. Calbet JA, MacLean DA. Role of caloric content on gastric emptying in humans. J Physiol 1997;498 ( Pt 2):553-9.

25. Phillips SM. Insulin and muscle protein turnover in humans: stimulatory, permissive, inhibitory, or all of the above? Am J Physiol Endocrinol Metab 2008;295(4):E731.

26. Timmerman KL, Lee JL, Dreyer HC, Dhanani S, Glynn EL, Fry CS, Drummond MJ, Sheffield-Moore M, Rasmussen BB, Volpi E. Insulin stimulates human skeletal muscle protein synthesis via an indirect mechanism involving endothelial-dependent vasodilation and mammalian target of rapamycin complex 1 signaling. J Clin Endocrinol Metab 2010;95(8):3848-57.

27. Timmerman KL, Lee JL, Fujita S, Dhanani S, Dreyer HC, Fry CS, Drummond MJ, Sheffield-Moore M, Rasmussen BB, Volpi E. Pharmacological vasodilation improves insulin-stimulated muscle protein anabolism but not glucose utilization in older adults. Diabetes 2010;59(11):2764-71.

28. Greenhaff PL, Karagounis LG, Peirce N, Simpson EJ, Hazell M, Layfield R, Wackerhage H, Smith K, Atherton P, Selby $A$, et al. Disassociation between the effects of amino acids and insulin on signaling, ubiquitin ligases, and protein turnover in human muscle. Am J Physiol Endocrinol Metab 2008;295(3):E595-604.

29. Guillet C, Zangarelli A, Gachon P, Morio B, Giraudet C, Rousset P, Boirie Y. Whole body protein breakdown is less inhibited by insulin, but still responsive to amino acid, in nondiabetic elderly subjects. J Clin Endocrinol Metab 2004;89(12):6017-24.

30. Volpi E, Sheffield-Moore M, Rasmussen BB, Wolfe RR. Basal muscle amino acid kinetics and protein synthesis in healthy young and older men. Jama 2001;286(10):1206-12.

31. Katsanos CS, Kobayashi H, Sheffield-Moore M, Aarsland A, Wolfe RR. Aging is associated with diminished accretion of muscle proteins after the ingestion of a small bolus of essential amino acids. Am J Clin Nutr 2005;82(5):1065-73.

32. Drummond MJ, Dreyer HC, Pennings B, Fry CS, Dhanani S, Dillon EL, Sheffield-Moore M, Volpi E, Rasmussen BB. Skeletal muscle protein anabolic response to resistance exercise and essential amino acids is delayed with aging. J Appl Physiol 2008;104(5):1452-61.

33. Glynn EL, Fry CS, Drummond MJ, Dreyer HC, Dhanani S, Volpi E, Rasmussen BB. Muscle protein breakdown has a minor role in the protein anabolic response to essential amino acid and carbohydrate intake following resistance exercise. American journal of physiology Regulatory, integrative and comparative physiology 2010;299(2):R533-40.

34. Glynn EL, Fry CS, Timmerman KL, Drummond MJ, Volpi E, Rasmussen BB. Addition of Carbohydrate or Alanine to an Essential Amino Acid Mixture Does Not Enhance Human Skeletal Muscle Protein Anabolism. J Nutr 2013.

35. Henderson GC, Dhatariya K, Ford GC, Klaus KA, Basu R, Rizza RA, Jensen MD, Khosla S, O'Brien P, Nair KS. Higher muscle protein synthesis in women than men across the lifespan, and failure of androgen administration to amend age-related decrements. Faseb J 2009;23(2):631-41.

36. Smith GI, Atherton P, Villareal DT, Frimel TN, Rankin D, Rennie MJ, Mittendorfer B. Differences in muscle protein synthesis and anabolic signaling in the postabsorptive state and in response to food in $65-80$ year old men and women. PLoS One 2008;3(3):e1875.

37. Smith GI, Reeds DN, Hall AM, Chambers KT, Finck BN, Mittendorfer B. Sexually dimorphic effect of aging on skeletal muscle protein synthesis. Biol Sex Differ 2012;3(1):11.

38. Smith GI, Villareal DT, Sinacore DR, Shah K, Mittendorfer B. Muscle Protein Synthesis Response to Exercise Training In Obese, Older Men and Women. Med Sci Sports Exerc 2012.

39. Fujita S, Rasmussen BB, Bell JA, Cadenas JG, Volpi E. Basal muscle intracellular amino acid kinetics in women and men. Am J Physiol Endocrinol Metab 2007;292(1):E77-83.

40. Jahn LA, Barrett EJ, Genco ML, Wei L, Spraggins TA, Fryburg DA. Tissue composition affects measures of postabsorptive human skeletal muscle metabolism: comparison across genders. J Clin Endocrinol Metab 1999;84(3):1007-10.

41. Smith Gl, Atherton P, Reeds DN, Mohammed BS, Jaffery H, Rankin D, Rennie MJ, Mittendorfer B. No major sex differences in muscle protein synthesis rates in the postabsorptive state and during hyperinsulinemiahyperaminoacidemia in middle-aged adults. Journal of applied physiology (Bethesda, Md : 1985) 2009;107(4):1308-15.

42. West DW, Burd NA, Churchward-Venne TA, Camera DM, Mitchell CJ, Baker SK, Hawley JA, Coffey VG, Phillips SM. Sex-based comparisons of myofibrillar protein synthesis after resistance exercise in the fed state. Journal of applied physiology (Bethesda, Md : 1985) 2012;112(11):1805-13. 



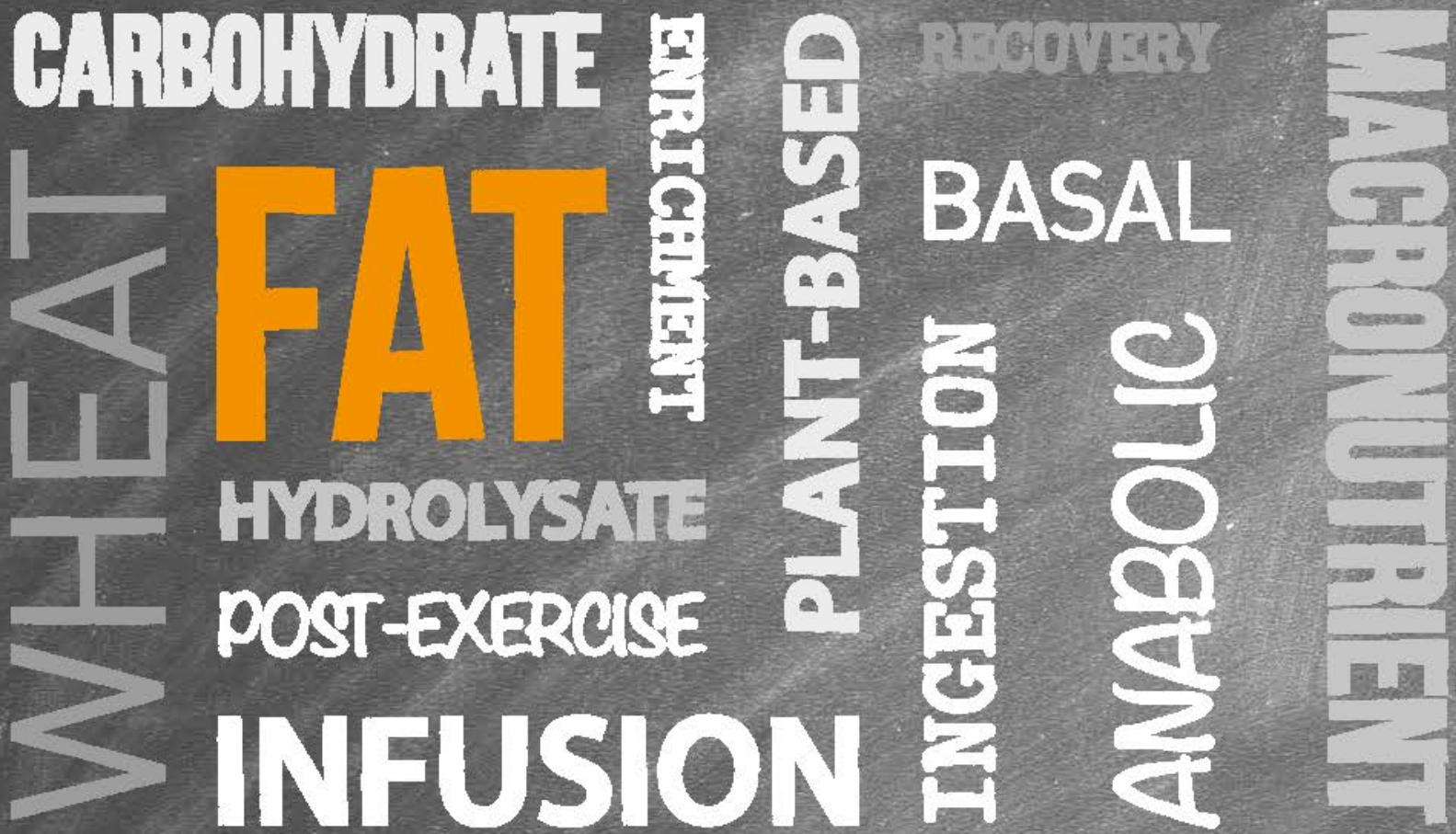

stlibe
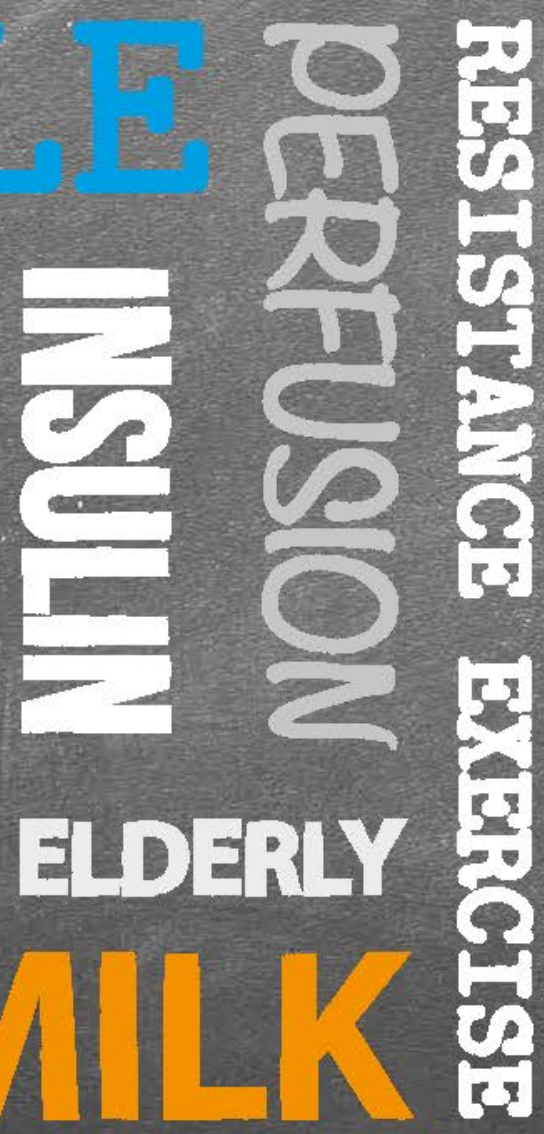

O) 5 CIRCULATION 


\section{SARCOPENIA}

\section{CHAPTER 3}

Co-ingesting milk fat with micellar casein does not affect postprandial protein handling in healthy older men

Stefan H. M. Gorissen

Nicholas A. Burd Irene Fleur Kramer Janneau van Kranenburg Annemie P. Gijsen Olav Rooyackers Luc J. C. van Loon

Clin Nutr. 2015
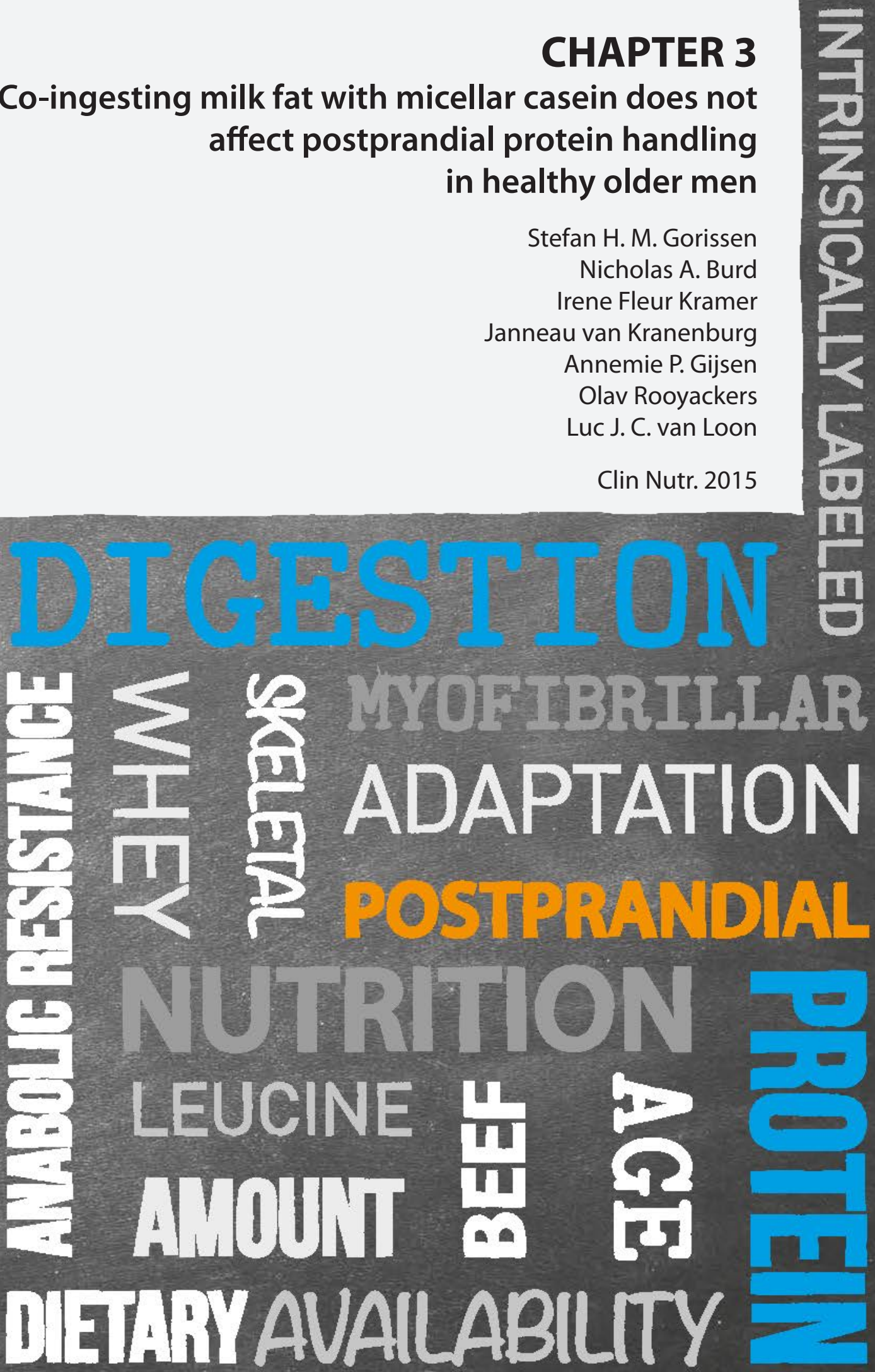


\section{ABSTRACT}

BACKGROUND \& AIM: Dietary protein digestion and absorption plays an important role in modulating postprandial muscle protein synthesis. The impact of co-ingesting other macronutrients with dietary protein on protein digestion and absorption and the subsequent muscle protein synthetic response remains largely unexplored. This study investigated the impact of co-ingesting milk fat with micellar casein on dietary protein-derived amino acid appearance in the circulation and the subsequent postprandial muscle protein synthetic response in healthy older men.

METHODS: Twenty-four healthy, older males (age: $65 \pm 1 \mathrm{y}, \mathrm{BMI}: 25.7 \pm 0.5 \mathrm{~kg} \cdot \mathrm{m}^{-2}$ ) received a primed continuous infusion of $\mathrm{L}$-[ring- $\left.{ }^{2} \mathrm{H}_{5}\right]$-phenylalanine and $\mathrm{L}-\left[1-{ }^{13} \mathrm{C}\right]$-leucine and ingested $20 \mathrm{~g}$ intrinsically L-[1-13 C]-phenylalanine and L- $\left[1-{ }^{13} \mathrm{C}\right]$-leucine-labeled casein with (PRO+FAT; $n=12$ ) or without (PRO; $n=12) 26.7 \mathrm{~g}$ milk fat. Plasma samples and muscle biopsies were collected in both the post-absorptive and postprandial state.

RESULTS: Release of dietary protein-derived phenylalanine into the circulation increased following protein ingestion $(\mathrm{P}<0.001)$ and tended to be higher in PRO compared with PRO+FAT (TimexTreatment $\mathrm{P}=0.076$ ). No differences were observed in dietary protein-derived plasma phenylalanine availability ( $52 \pm 2$ vs $52 \pm 3 \%$ in $\mathrm{PRO}$ vs $\mathrm{PRO}+\mathrm{FAT}$, respectively; $\mathrm{P}=0.868$ ). Myofibrillar protein synthesis rates did not differ between treatments, calculated using either the L-[ring- ${ }^{2} \mathrm{H}_{5}$ ]phenylalanine $\left(0.036 \pm 0.003\right.$ vs $0.036 \pm 0.004 \% \cdot \mathrm{h}^{-1}$ after $\mathrm{PRO}$ vs $\mathrm{PRO}+\mathrm{FAT}$, respectively; $\left.\mathrm{P}=0.933\right)$ or $\mathrm{L}$-[1- $\left.{ }^{13} \mathrm{C}\right]$-leucine $\left(0.051 \pm 0.004\right.$ vs $0.046 \pm 0.004 \% \cdot \mathrm{h}^{-1}$, respectively; $\left.\mathrm{P}=0.480\right)$ tracer. In accordance, no differences were observed in myofibrillar protein-bound $\mathrm{L}-\left[1-{ }^{13} \mathrm{C}\right]$-phenylalanine enrichments between treatments $(0.018 \pm 0.002$ vs $0.014 \pm 0.001 \mathrm{MPE}$, respectively; $\mathrm{P}=0.173)$.

CONCLUSION: Co-ingesting milk fat with micellar casein does not impair protein-derived phenylalanine appearance in the circulation and does not modulate postprandial myofibrillar protein synthesis rates. 


\section{INTRODUCTION}

The age-related loss of skeletal muscle mass and function, referred to as sarcopenia, is at least partly attributed to a blunted muscle protein synthetic response to protein ingestion $(1,2)$. There are numerous processes that occur between protein ingestion and the increase in postprandial muscle protein synthesis which may be compromised with aging (3): protein digestion and absorption (4), utilization of dietary protein-derived amino acids by splanchnic organs (5), plasma amino acid availability, skeletal muscle perfusion, delivery of amino acids to the muscle (6), and uptake of amino acids by the muscle (7). A meal generally includes all macronutrients, with carbohydrate and fat being co-ingested with protein. In a previous study, we assessed the impact of carbohydrate co-ingestion with protein on protein digestion and absorption kinetics as well as the subsequent postprandial muscle protein synthetic response in young and older adults (4). Carbohydrate co-ingestion was shown to delay dietary protein digestion and absorption, but did not impair the subsequent postprandial rise in muscle protein synthesis rates in young or older men (4).

Interestingly, little is known about the impact of fat co-ingestion with protein on dietary protein digestion and absorption kinetics and the subsequent postprandial muscle protein synthetic response. Elliot et al. (8) observed a more positive leg protein balance following the ingestion of whole milk when compared with fat-free milk. The authors speculated that fat co-ingestion could have stimulated postprandial muscle protein synthesis (8). In contrast, it could also be speculated that co-ingesting fat with protein slows down gastric emptying (9), thereby compromising dietary protein digestion and absorption. This would blunt the postprandial rise in plasma amino acid availability $(10,11)$ and subsequently lower postprandial muscle protein synthesis rates $(12,13)$. We hypothesize that fat co-ingestion with protein delays dietary protein-derived phenylalanine appearance in the circulation and attenuates the postprandial rise in myofibrillar protein synthesis rates.

In the present study, we investigated the impact of co-ingesting milk fat with micellar casein on the appearance rates of dietary protein-derived amino acids in the circulation and the subsequent muscle protein synthetic response. By combining the ingestion of intrinsically $\mathrm{L}-\left[1-{ }^{13} \mathrm{C}\right]-$ phenylalanine and $\mathrm{L}-\left[1-{ }^{13} \mathrm{C}\right]$-leucine-labeled protein with intravenous infusions of $\mathrm{L}-\left[\mathrm{ring}^{-2} \mathrm{H}_{5}\right]-$ phenylalanine and $\mathrm{L}-\left[1-{ }^{13} \mathrm{C}\right]$-leucine, we are able to assess splanchnic amino acid extraction, appearance rates of dietary protein-derived amino acids in the circulation, the incorporation of dietary protein-derived amino acids into skeletal muscle protein, as well as muscle protein synthesis rates in vivo in humans (14). This is the first study to provide a detailed description on the effect of fat co-ingestion with protein on protein digestion and absorption kinetics and the subsequent postprandial muscle protein synthetic response in healthy, older males. 


\section{MetHODS}

\section{PARTICIPANTS}

Twenty-four healthy, older men (age: $65 \pm 1$ y) participated in this parallel group, randomized controlled trial. The trial was conducted between October 2012 and December 2012 at Maastricht University in Maastricht, The Netherlands. Participants' characteristics are presented in Table 3.1. None of the participants were involved in a regular exercise program. All participants were informed about the purpose of the study, the experimental procedures, and all its possible risks prior to providing written consent to participate. This study was approved by the Medical Ethics Committee of the Academic Hospital Maastricht and conformed to the standards set by the Declaration of Helsinki of October 2008.

Table 3.1 | Subjects' characteristics

\begin{tabular}{|c|c|c|c|}
\hline & $\begin{array}{c}\text { PRO } \\
(n=12)\end{array}$ & $\begin{array}{c}\text { PRO+FAT } \\
(n=12)\end{array}$ & $P$ value \\
\hline Age (y) & $63 \pm 2$ & $67 \pm 2$ & 0.162 \\
\hline Weight (kg) & $79.4 \pm 2.1$ & $84.8 \pm 2.0$ & 0.078 \\
\hline $\mathrm{BMI}\left(\mathrm{kg} \cdot \mathrm{m}^{-2}\right)$ & $24.8 \pm 0.7$ & $26.6 \pm 0.4$ & 0.051 \\
\hline Systolic BP (mmHg) & $139 \pm 3$ & $131 \pm 3$ & 0.092 \\
\hline Diastolic BP (mmHg) & $81 \pm 3$ & $70 \pm 2$ & 0.011 \\
\hline Fat (\%) & $19.4 \pm 1.3$ & $19.6 \pm 1.1$ & 0.907 \\
\hline Appendicular lean mass (\%) & $34.6 \pm 0.7$ & $34.1 \pm 0.9$ & 0.675 \\
\hline Lean body mass (\%) & $77.0 \pm 1.2$ & $76.9 \pm 1.1$ & 0.924 \\
\hline Quadriceps CSA $\left(\mathrm{cm}^{2}\right)$ & $70.4 \pm 1.4$ & $71.7 \pm 2.4$ & 0.645 \\
\hline Fasting glucose $\left(\mathrm{mmol} \cdot \mathrm{L}^{-1}\right)$ & $6.2 \pm 0.2$ & $6.0 \pm 0.1$ & 0.529 \\
\hline $2 \mathrm{~h}$ glucose $\left(\mathrm{mmol} \cdot \mathrm{L}^{-1}\right)$ & $6.3 \pm 0.4$ & $6.8 \pm 0.8$ & 0.642 \\
\hline $\mathrm{HbA}_{1 \mathrm{c}}(\%)$ & $5.7 \pm 0.1$ & $5.6 \pm 0.1$ & 0.489 \\
\hline $\mathrm{OGIS}\left(\mathrm{mL} \cdot \mathrm{min}^{-1} \cdot \mathrm{m}^{-2}\right)$ & $356 \pm 15$ & $345 \pm 20$ & 0.675 \\
\hline
\end{tabular}

Abbreviations: $\mathrm{CSA}$, cross-sectional area; $\mathrm{HbA}_{1 c}$, glycosylated hemoglobin; OGIS, oral glucose insulin sensitivity. Values are means \pm SEM. Data were analyzed by a Student's two-sample t-Test.

\section{PRETESTING}

Participants underwent a medical screening to assess their $\mathrm{HbA}_{1 c}$, glucose tolerance (by a $2 \mathrm{~h}$ oral glucose tolerance test (15)), blood pressure, weight, height, and body composition (by Dualenergy X-ray absorptiometry; Discovery A; Hologic, Bedford, MA). A computed tomography scan was performed on the upper leg to determine the cross-sectional area of the quadriceps muscle. The participants were deemed healthy based on their responses to a medical questionnaire and screening results. Afterwards, participants were randomly assigned to ingest either micellar casein (PRO) or micellar casein in combination with milk fat (PRO+FAT). Randomization was computergenerated and participants, researchers, and technicians were blinded to the group allocation. Beverages were prepared in coded containers by an independent research assistant. 


\section{DIET AND PHYSICAL ACTIVITY CONTROL}

All participants were instructed to refrain from any sort of strenuous physical activity and to maintain their diet as constant as possible for $2 \mathrm{~d}$ prior to the infusion trial. On the evening before the infusion trial, all participants consumed a standardized meal $\left(29.3 \pm 0.5 \mathrm{~kJ}^{\circ} \mathrm{kg}^{-1}\right.$ body weight) composed of 16 energy percent (En\%) protein, $33 \mathrm{En} \%$ carbohydrate, and $51 \mathrm{En} \%$ fat.

\section{INFUSION PROTOCOL}

At 08:00 AM, following an overnight fast, participants arrived at the laboratory by car or public transport. A Teflon catheter was inserted into an antecubital vein for stable isotope amino acid infusion. A second Teflon catheter was inserted into a dorsal hand vein of the contralateral arm and placed in a hot-box $\left(60^{\circ} \mathrm{C}\right)$ for arterialized blood sampling (16). After taking a baseline blood sample, the plasma phenylalanine, tyrosine, and leucine pools were primed with a single dose of L[ring- $\left.{ }^{2} \mathrm{H}_{5}\right]$-phenylalanine $\left(2.0 \mu \mathrm{mol} \cdot \mathrm{kg}^{-1}\right), \mathrm{L}$-[ring-3,5- $\left.{ }^{2} \mathrm{H}_{2}\right]$-tyrosine $\left(0.6 \mu \mathrm{mol} \cdot \mathrm{kg}^{-1}\right)$, and $\mathrm{L}-\left[1-{ }^{13} \mathrm{C}\right]-$ leucine $\left(4.0 \mu \mathrm{mol} \cdot \mathrm{kg}^{-1}\right)$, after which a continuous $\mathrm{L}-\left[\mathrm{ring}-{ }^{2} \mathrm{H}_{5}\right]$-phenylalanine $\left(0.050 \mu \mathrm{mol} \cdot \mathrm{kg}^{-1} \cdot \mathrm{min}^{-1}\right)$, L-[ring-3,5- $\left.{ }^{2} \mathrm{H}_{2}\right]$-tyrosine $\left(0.015 \mu \mathrm{mol} \cdot \mathrm{kg}^{-1} \cdot \mathrm{min}^{-1}\right)$, and $\mathrm{L}-\left[1{ }^{13} \mathrm{C}\right]$-leucine $\left(0.100 \mu \mathrm{mol} \cdot \mathrm{kg}^{-1} \cdot \mathrm{min}^{-1}\right)$ intravenous infusion was initiated $(\mathrm{t}=-210 \mathrm{~min})$. After resting in a supine position for $90 \mathrm{~min}, \mathrm{a}$ second arterialized blood sample was drawn and a muscle biopsy was collected from the vastus lateralis ( $\mathrm{t}=-120 \mathrm{~min}$ ). To determine basal muscle protein synthesis rates, a second muscle biopsy from the same leg was collected $120 \mathrm{~min}$ after the first biopsy. Subsequently, participants received a beverage containing $20 \mathrm{~g}$ of intrinsically L-[1- $\left.{ }^{13} \mathrm{C}\right]$-phenylalanine and $\mathrm{L}-\left[1-{ }^{13} \mathrm{C}\right]$-leucine-labeled micellar casein with (PRO+FAT) or without (PRO) $26.7 \mathrm{~g}$ anhydrous milk fat $(\mathrm{t}=0 \mathrm{~min})$. Arterialized blood samples were subsequently collected at $\mathrm{t}=-90,-60,-30,0,15,30,45,60,75,90,120,150,180$, $210,240,270$, and $300 \mathrm{~min}$. A third and fourth muscle biopsy was collected from the contralateral leg at $\mathrm{t}=120$ and $\mathrm{t}=300 \mathrm{~min}$, respectively, to determine postprandial muscle protein synthesis rates. Blood samples were collected in EDTA containing tubes and centrifuged at $1000 \times g$ for 10 $\min$ at $4^{\circ} \mathrm{C}$. Aliquots of plasma were frozen in liquid nitrogen and stored at $-80^{\circ} \mathrm{C}$. Biopsies were collected from the middle region of the vastus lateralis, approximately $15 \mathrm{~cm}$ above the patella and $3 \mathrm{~cm}$ below entry through the fascia, using the percutaneous needle biopsy technique (17). Muscle samples were dissected carefully, freed from any visible non-muscle material, immediately frozen in liquid nitrogen, and stored at $-80^{\circ} \mathrm{C}$ until further analysis. For a schematic representation of the infusion protocol please see Figure 3.1.

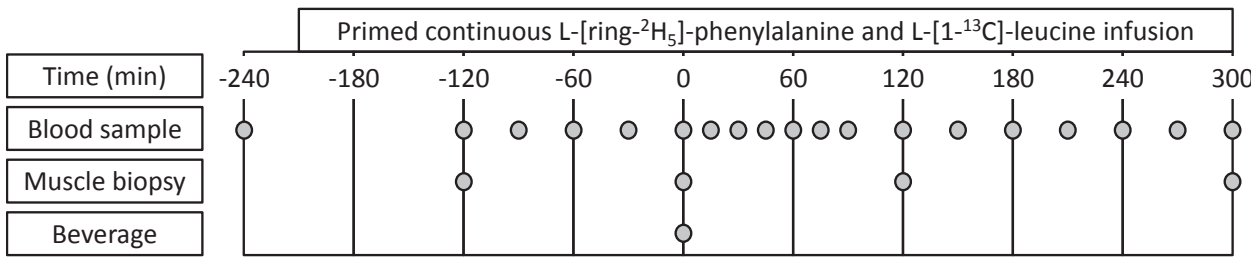

Figure 3.1 | Schematic representation of the infusion protocol

\section{PREPARATION OF INTRINSICALLY LABELED PROTEIN AND BEVERAGE COMPOSITION}

Intrinsically L- $\left[1-{ }^{13} \mathrm{C}\right]$-phenylalanine and $\mathrm{L}-\left[1-{ }^{13} \mathrm{C}\right]$-leucine-labeled casein was prepared by infusing $\mathrm{L}-\left[1-{ }^{13} \mathrm{C}\right]$-phenylalanine and $\mathrm{L}-\left[1-{ }^{13} \mathrm{C}\right]$-leucine into a lactating Holstein cow, collecting milk, and purifying the casein fraction as described previously (18-20). The enrichments of $\mathrm{L}-\left[1-{ }^{13} \mathrm{C}\right]-$ phenylalanine and $\mathrm{L}-\left[1-{ }^{13} \mathrm{C}\right]$-leucine in the casein were 38.7 and 9.3 mole percent excess (MPE), 
respectively. The casein met all chemical and bacteriologic specifications for human consumption. Participants received a beverage containing $20 \mathrm{~g}$ of casein (containing $1.54 \mathrm{~g}$ leucine) with or without $26.7 \mathrm{~g}$ anhydrous milk fat obtained from pasteurized cream (FrieslandCampina, The Netherlands) in a total volume of $350 \mathrm{~mL}$. A homogenous beverage was obtained by heating the casein and fat to $45^{\circ} \mathrm{C}$ and mixing using a blender. The beverage was uniformly flavored by adding $2 \mathrm{~mL}$ vanilla flavor (Dr. Oetker, Amersfoort, the Netherlands).

\section{PLASMA AND MUSCLE TISSUE ANALYSES}

Plasma glucose, insulin, free fatty acid, and triglyceride concentrations were analyzed using commercially available kits (Glucose HK Gen.3, Roche, Ref: 05168791190; Elecsys Insulin assay, Roche, Ref: 12017547122; NEFA-HR(2), Wako, Neuss, Germany; and ABX Pentra Triglycerides CP, HORIBA ABX, Ref: A11A01640; respectively). Plasma amino acid concentrations and enrichments were determined by gas chromatography-mass spectrometry (GC-MS) as described previously (4). Myofibrillar protein-bound L-[ring- $\left.{ }^{2} \mathrm{H}_{5}\right]$-phenylalanine enrichments were determined by GC-MS analysis, and myofibrillar protein-bound $\mathrm{L}-\left[1-{ }^{13} \mathrm{C}\right]$-phenylalanine and $\mathrm{L}-\left[1-{ }^{13} \mathrm{C}\right]$-leucine enrichments were determined by gas chromatography-combustion-isotope ratio mass spectrometry (GC-CIRMS) analysis as described previously (4).

\section{CALCULATIONS}

Ingestion of L-[1- $\left.{ }^{13} \mathrm{C}\right]$-phenylalanine-labeled protein, intravenous infusion of $\mathrm{L}$-[ring- $\left.{ }^{2} \mathrm{H}_{5}\right]-$ phenylalanine and L-[ring-3,5- ${ }^{2} \mathrm{H}_{2}$ ]-tyrosine, and arterialized blood sampling were used to assess whole-body amino acid kinetics in non-steady state conditions. Total, exogenous, and endogenous rate of appearance $\left(R_{a}\right)$ and plasma availability of dietary protein-derived phenylalanine (i.e., the fraction of dietary protein-derived phenylalanine that appeared in the systemic circulation, Phe plasma $)$ were calculated using modified Steele's equations $(21,22)$ :

Total $R_{a}=\frac{F_{i v}-\left[p V \times C(t) \times \frac{d E_{i v}}{d t}\right]}{E_{i v}(t)}$

Exo $R_{a}=\frac{\operatorname{Total} R_{a} \times E_{p o}(t)+\left[p V \times C(t) \times \frac{d E_{p o}}{d t}\right]}{E_{\text {prot }}}$

Endo $R_{a}=$ Total $R_{a}-$ Exo $R_{a}-F_{\text {iv }}$

Phe $e_{\text {plasma }}=\left(\frac{A U C_{\text {Exo Ra }}}{\text { Phe }_{\text {prot }}}\right) \times B W \times 100 \%$

where $F_{i v}$ is the intravenous tracer infusion rate $\left(\mu \mathrm{mol} \cdot \mathrm{kg}^{-1} \cdot \mathrm{min}^{-1}\right) ; p V\left(0.125 \mathrm{~L} \cdot \mathrm{kg}^{-1}\right)$ is the distribution volume (21); $C(t)$ is the mean plasma phenylalanine concentration between two consecutive time points; $d E_{i v} / d t$ is the time-dependent variations of plasma phenylalanine enrichment derived from the intravenous tracer; and $E_{i v}(t)$ is the mean plasma phenylalanine enrichment derived from the intravenous tracer between two consecutive time points. Exo $R_{a}$ represents the rate at which dietary protein-derived phenylalanine enters the circulation, which provides an index of protein digestion and absorption. $E_{p o}(t)$ is the mean plasma phenylalanine enrichment derived from the oral tracer between two consecutive time points; $d E_{p o} / d t$ is the time-dependent variations of plasma phenylalanine enrichment derived from the oral tracer; and $E_{\text {prot }}$ is the $\mathrm{L}-\left[1-{ }^{13} \mathrm{C}\right]-$ 
phenylalanine enrichment of the dietary protein. $A \cup C_{E x o}$ Ra represents the area under the curve (AUC) of Exo $R_{a}$, which corresponds to the amount of dietary protein-derived phenylalanine that appeared in the circulation over the 5 -h postprandial period; Phe prot $_{\text {is }}$ the amount of dietary phenylalanine ingested; and $B W$ is the participants' body weight. The percentage of dietary protein-derived phenylalanine that appeared in the circulation (Phe plasma) is restricted to the $5 \mathrm{~h}$ assessment period.

Total phenylalanine rate of disappearance $\left(R_{d}\right)$ represents the rate of phenylalanine hydroxylation (first step in phenylalanine oxidation) plus the rate of phenylalanine utilization for protein synthesis. This parameter is calculated as follows:

Total $R_{d}=$ Total $R_{a}-p V \times \frac{d C}{d t}$

Phe hydroxylation $=$ Tyr $R_{a} \times \frac{E_{T y r}(t)}{E_{P h e}(t)} \times \frac{\text { Phe } R_{d}}{\left(F_{P h e}+P h e R_{d}\right)}$

Protein synthesis $=$ Total $R_{d}-$ Phe hydroxylation

Phe net balance $=$ Protein synthesis - Endo $R_{a}$

where $\operatorname{Tyr} R_{a}$ is the total rate of tyrosine appearance based on the L-[ring-3,5- $\left.{ }^{2} \mathrm{H}_{2}\right]$-tyrosine infusion and plasma enrichments. $E_{\text {Tyr }}(t)$ and $E_{\text {phe }}(t)$ represent the mean plasma L-[ring $\left.-{ }^{2} \mathrm{H}_{4}\right]$-tyrosine and L[ring ${ }^{2} \mathrm{H}_{5}$ ]-phenylalanine enrichment between 2 consecutive time points, respectively, and $F_{\text {Phe }}$ is the intravenous infusion rate of L-[ring- ${ }^{-} \mathrm{H}_{5}$-phenylalanine $\left(\mu \mathrm{mol}^{-} \mathrm{kg}^{-1} \cdot \mathrm{min}^{-1}\right)$.

Myofibrillar protein fractional synthetic rates (FSR) were calculated using the standard precursorproduct equation:

$F S R=\frac{\Delta E_{p}}{E_{\text {precursor }} \cdot t} \cdot 100 \%$

where $\Delta E_{p}$ is the increment in myofibrillar protein-bound L-[1- $\left.{ }^{13} \mathrm{C}\right]$-leucine or L-[ring- $\left.{ }^{2} \mathrm{H}_{5}\right]$ phenylalanine enrichment after an incorporation period (tracer-to-tracee ratio, TTR), $E_{\text {precuror }}$ is the weighted mean plasma $\mathrm{L}-\left[1{ }^{13} \mathrm{C}\right]$-leucine or $\mathrm{L}-\left[\mathrm{ring}^{-}{ }^{-} \mathrm{H}_{5}\right]$-phenylalanine enrichment during that incorporation period (TRR), and $t$ is the incorporation period (h). For basal FSR, muscle biopsies at $\mathrm{t}=-120$ and $0 \mathrm{~min}$ were used, and for postprandial FSR, biopsies at $\mathrm{t}=0,120$, and $300 \mathrm{~min}$ were used.

\section{STATISTICS}

All data are expressed as mean \pm SEM. Incremental area under curve (iAUC), peak value, and time to peak were calculated for all plasma time curves. A Student's t-test was applied to identify differences between treatments. For plasma and muscle time curves, a repeated measures ANOVA with treatment, time, and their interaction was used to identify differences between treatments over time. Statistical significance was set at $P<0.05$. All calculations were performed using IBM SPSS Statistics (version 20). 


\section{RESULTS}

\section{PLASMA METABOLITES}

Plasma glucose concentrations declined over time from $6.1 \pm 0.1$ to $5.7 \pm 0.1 \mathrm{mmol} \cdot \mathrm{L}^{-1}(\mathrm{P}<0.001)$, with no differences between treatments (Figure 3.2A). Plasma insulin concentrations slightly decreased during the fasting period $(P<0.001)$ and transiently increased after protein ingestion $(P<0.001)$, with no differences between treatments (Figure 3.2B). Incremental AUC of insulin was higher in the PRO+FAT when compared with the PRO condition ( $707 \pm 123$ vs $349 \pm 102$, respectively; $P=0.035)$, whereas peak values did not differ between PRO and PRO+FAT $\left(15.3 \pm 2.1\right.$ and $20.0 \pm 3.6 \mathrm{mU} \cdot \mathrm{L}^{-1}$; $\mathrm{P}=0.275$ ). Plasma free fatty acid (FFA) concentrations increased during the fasting period $(P<0.001)$ and transiently decreased after protein ingestion in both the PRO and PRO+FAT treatment $(\mathrm{P}<0.001$; Figure 3.2C). A significant treatment effect was observed between the PRO and PRO+FAT condition ( $P=0.040)$, which was attributed to a tendency for baseline differences in plasma FFA concentrations between groups ( $P=0.094)$. Plasma triglyceride $(T G)$ concentrations decreased over time during the fasting period $(P<0.001$; Figure 3.2D). Beverage ingestion increased plasma TG concentrations to a greater extent in the PRO+FAT when compared with the PRO treatment (TimexTreatment $\mathrm{P}<0.001$ ). Consequently, incremental AUC was higher in the PRO+FAT when compared with PRO treatment ( $32332 \pm 7753$ vs $1711 \pm 4935$, respectively; $\mathrm{P}=0.003$ ).

A

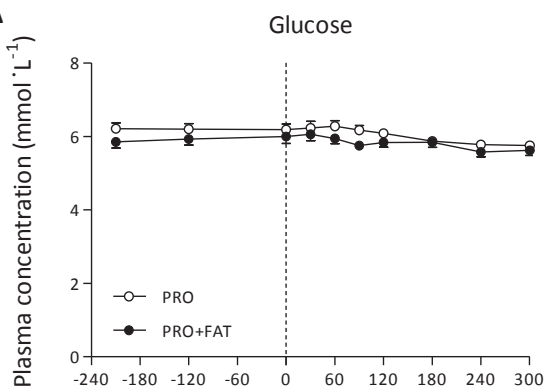

B

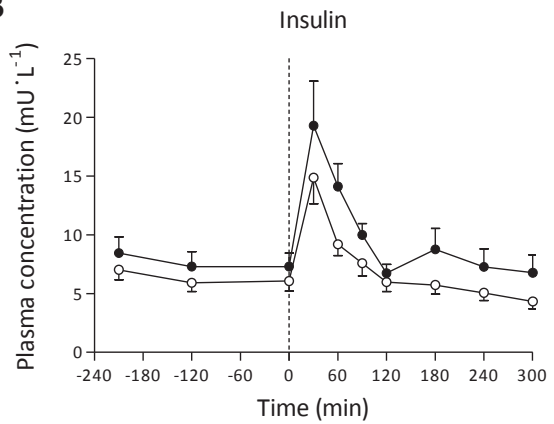

C

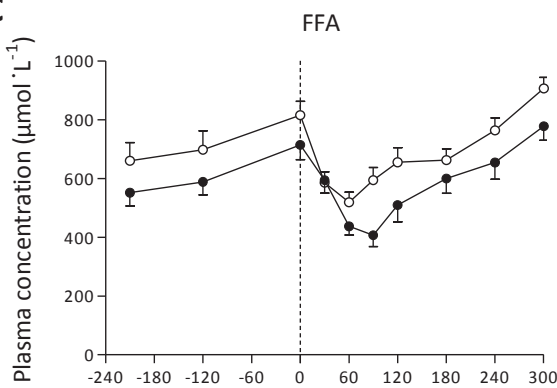

D

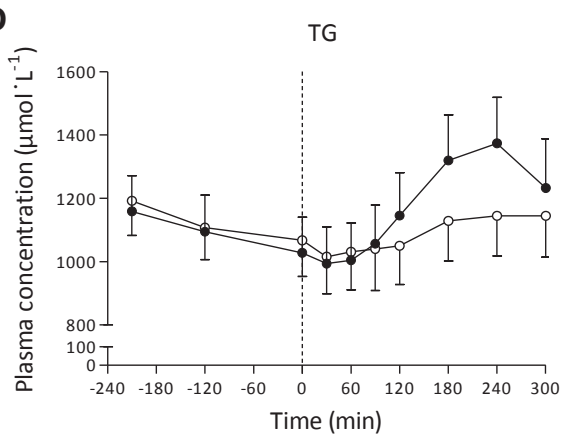

Figure 3.2 | Mean ( \pm SEM) plasma glucose (A), insulin (B), free fatty acid (FFA; C), and triglyceride (TG; D) concentrations ( $\mathrm{mmol} \cdot \mathrm{L}^{-1}, \mathrm{mU} \cdot \mathrm{L}^{-1}, \mathrm{mmol} \cdot \mathrm{L}^{-1}$, and $\mathrm{mmol} \cdot \mathrm{L}^{-1}$, respectively) during the fasting period and following the ingestion of $20 \mathrm{~g}$ micellar casein with (PRO+FAT; $n=12$ ) or without (PRO; $n=12) 26.7 \mathrm{~g}$ anhydrous milk fat. Glucose: Time effect $\mathrm{P}<0.001$, TimexTreatment $P=0.219$; Insulin: Time effect $P<0.001$, TimexTreatment $P=0.330$, iAUC $P=0.035$, Peak value $P=0.275$; FFA: Time effect $P<0.001$, Treatment effect $P=0.040$; TG: TimexTreatment $P<0.001$, iAUC $P=0.003$. 
Plasma amino acid levels transiently increased following protein ingestion ( $P<0.001$; Figure 3.3). The postprandial rise in tyrosine concentrations was significantly higher (TimexTreatment $\mathrm{P}=0.042$ ) and the postprandial rise in leucine concentrations tended to be higher (TimexTreatment $\mathrm{P}=0.078$ ) in the $\mathrm{PRO}$ when compared with PRO+FAT treatment. As a consequence, postprandial tyrosine incremental $A U C$ tended to be greater in the PRO vs PRO+FAT treatment $(6464 \pm 535$ vs $5012 \pm 484 ; \mathrm{P}=0.056)$.

A

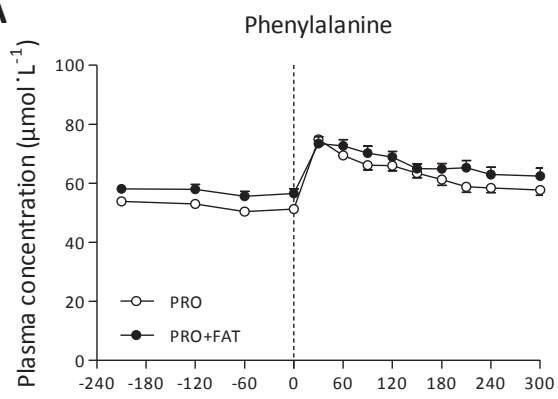

C

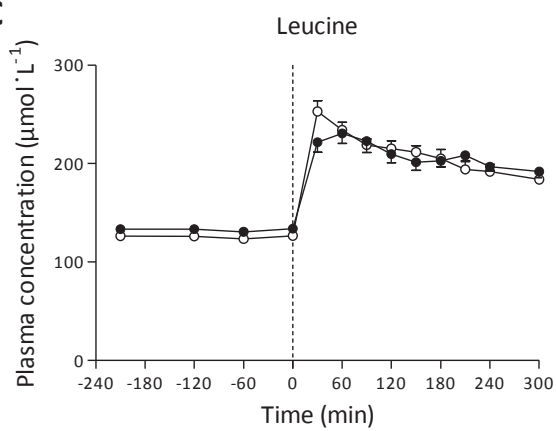

B

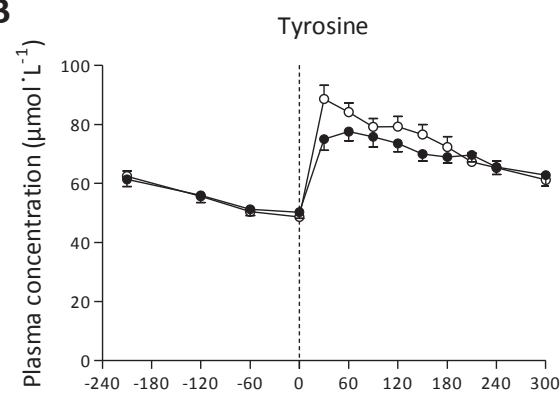

Figure 3.3 | Mean ( \pm SEM) plasma phenylalanine (A), tyrosine (B), and leucine $(C)$ concentrations $\left(\mu \mathrm{mol}^{-1} \mathrm{~L}^{-1}\right)$ during the fasting period and following the ingestion of $20 \mathrm{~g}$ micellar casein with (PRO+FAT; $n=12$ ) or without (PRO; $n=12) 26.7 \mathrm{~g}$ anhydrous milk fat. Phenylalanine: Time effect $P<0.001$, TimexTreatment $P=0.209$; Tyrosine: Time effect $P<0.001$, TimexTreatment $P=0.042$, iAUC P0.056; Leucine: Time effect $P<0.001$, TimexTreatment $P=0.078$. * Significantly different between treatments at this time point.

\section{PLASMA TRACERS}

Plasma L-[ring- $\left.{ }^{2} \mathrm{H}_{5}\right]$-phenylalanine (infused tracer), L-[1- $\left.{ }^{13} \mathrm{C}\right]$-phenylalanine (ingested tracer), and L$\left[1-{ }^{13} \mathrm{C}\right]$-leucine (both infused and ingested tracer) enrichments are shown in Figure 3.4. Plasma L[ring- ${ }^{2} \mathrm{H}_{5}$ ]-phenylalanine enrichments declined following protein ingestion (Figure 3.4A). This decline was greater in the PRO when compared with PRO+FAT treatment (TimexTreatment $\mathrm{P}=0.016)$. Plasma $\mathrm{L}-\left[1-{ }^{13} \mathrm{C}\right]$-phenylalanine enrichments rapidly increased following protein ingestion $(\mathrm{P}<0.001)$ and were higher in $\mathrm{PRO}$ when compared with PRO+FAT during the first 3 hours (TimexTreatment $\mathrm{P}=0.041$; Figure 3.4B). Plasma $\mathrm{L}-\left[1-{ }^{13} \mathrm{C}\right]$-leucine enrichments increased during the first $30 \mathrm{~min}$ after protein ingestion, and remained stable from $30 \mathrm{~min}$ onwards with no differences between treatments (Figure 3.4C). 
A

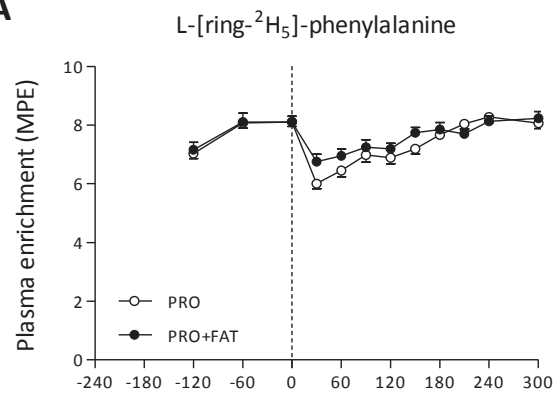

B

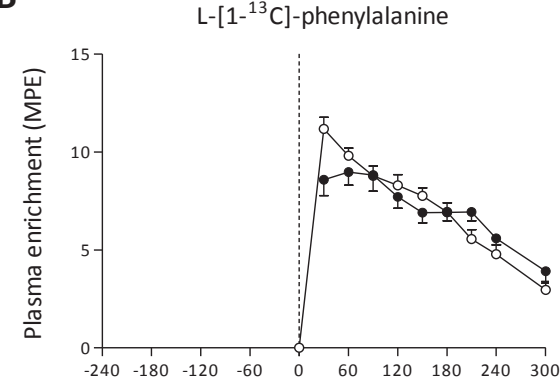

C

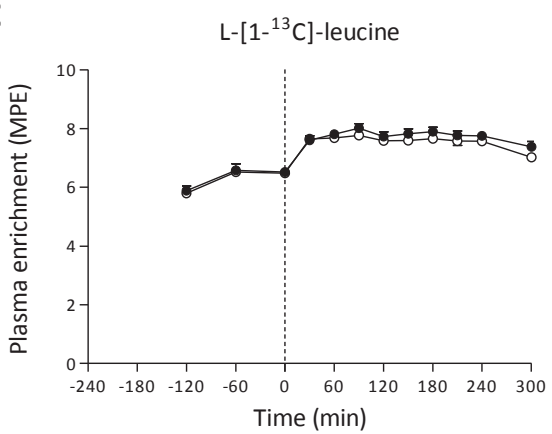

Figure 3.4 Mean ( \pm SEM) plasma L-[ring $\left.-{ }^{2} \mathrm{H}_{5}\right]$-phenylalanine $(\mathrm{A}), \mathrm{L}-\left[1-{ }^{13} \mathrm{C}\right]$-phenylalanine $(\mathrm{B})$, and L-[1-13 C]-leucine $(\mathrm{C})$ enrichments (MPE) during the fasting period and following the ingestion of $20 \mathrm{~g}$ micellar casein with (PRO+FAT; $n=12)$ or without (PRO; $n=12$ ) $26.7 \mathrm{~g}$ anhydrous milk fat. L-[ring- ${ }^{2} \mathrm{H}_{5}$ ]-phenylalanine: Time effect $\mathrm{P}<0.001$, TimexTreatment $P=0.016 ; L-\left[1-{ }^{13} \mathrm{C}\right]$-phenylalanine: Time effect $P<0.001$, TimexTreatment $P=0.041 ; L-\left[1-{ }^{13} \mathrm{C}\right]$-leucine: Time effect $P<0.001$, TimexTreatment $\mathrm{P}=0.373$. ${ }^{*}$ Significantly different between treatments at this time point.

\section{WHOLE-BODY PHENYLALANINE KINETICS}

Figure 3.5 shows whole-body phenylalanine kinetics. Exogenous phenylalanine appearance rates (i.e., the rate at which dietary protein-derived phenylalanine enters the circulation) rapidly increased following protein ingestion $(P<0.001)$ and tended to be higher during the first 3 hours in the PRO when compared with PRO+FAT treatment (TimexTreatment $P=0.076$; Figure 3.5A). Peak rates and time to reach peak rates did not differ between treatments $(P=0.167$ and $P=0.201$, respectively). The percentage of dietary protein-derived phenylalanine that appeared in the circulation over the $5 \mathrm{~h}$ postprandial period did not differ between groups and averaged $52 \pm 2$ and $52 \pm 3 \%$ in the PRO and PRO+FAT treatment, respectively $(\mathrm{P}=0.868)$. Endogenous phenylalanine appearance rates (i.e., the rate at which phenylalanine derived from whole-body protein breakdown enters the circulation) declined following protein ingestion $(P<0.001$; Figure 3.5B), with no differences between treatments (TimexTreatment $\mathrm{P}=0.343$ ). Protein ingestion increased total rate of phenylalanine appearance (Figure $3.5 \mathrm{C}$ ) and total rate of phenylalanine disappearance (Figure 3.5D) to a greater extent in the PRO compared with PRO+FAT treatment (TimexTreatment $\mathrm{P}=0.041$ and $\mathrm{P}=0.035$, respectively). Peak phenylalanine appearance rates were significantly higher in the PRO when compared with the PRO+FAT treatment $\left(0.82 \pm 0.02\right.$ vs $0.76 \pm 0.02 \mu \mathrm{mol} \cdot \mathrm{kg}^{-1} \cdot \mathrm{min}^{-1}$; $\mathrm{P}=0.047)$. 
A

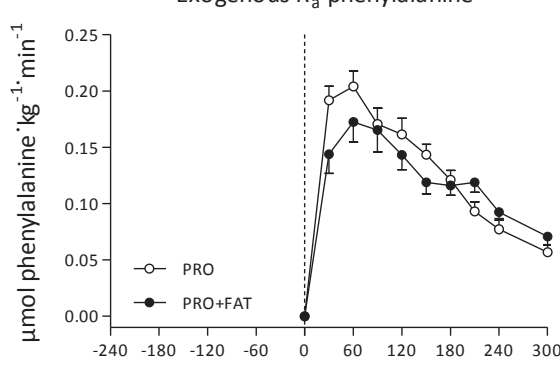

C

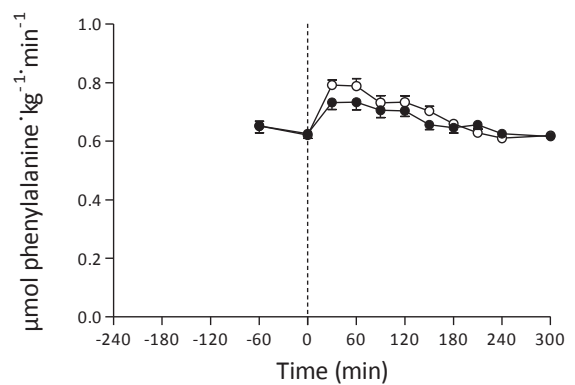

B

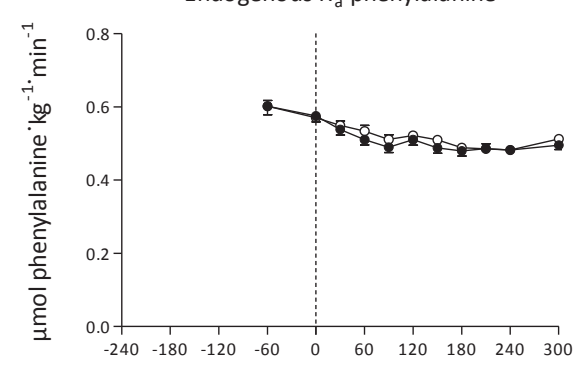

D

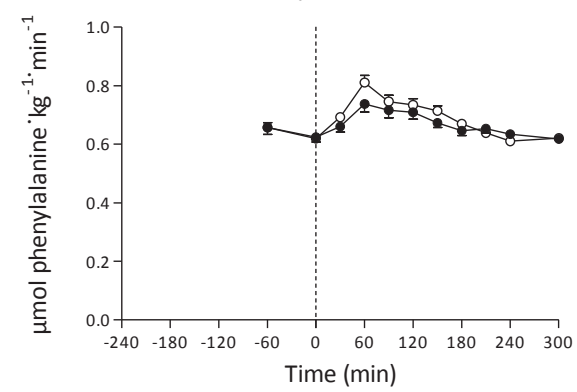

Figure 3.5 | Whole-body phenylalanine kinetics. Mean ( \pm SEM) exogenous rate of appearance $\left(R_{a} ; A\right)$, endogenous $R_{a}(B)$, total $R_{a}(C)$, and total rate of disappearance $\left(R_{d} ; D\right)\left(\mu \mathrm{mol} \cdot \mathrm{kg}^{-1} \cdot \mathrm{min}^{-1}\right)$ during the fasting period and following the ingestion of $20 \mathrm{~g}$ micellar casein with (PRO+FAT; $n=12$ ) or without (PRO; $n=12) 26.7 \mathrm{~g}$ anhydrous milk fat. Exogenous $\mathrm{R}_{\mathrm{a}}$ : Time effect $P<0.001$, TimexTreatment $P=0.076$, Peak value $P=0.167$, Time to peak $P=0.201$; Endogenous $R a$ : Time effect $P<0.001$, TimexTreatment $P=0.343$; Total $R_{a}$ : Time effect $P<0.001$, TimexTreatment $P=0.041$, Peak value $P=0.047$; Total $R_{d}$ : Time effect $P<0.001$, TimexTreatment $P=0.035$, Peak value $P=0.094$. * Significantly different between treatments at this time point.

Post-absorptive and postprandial whole-body protein breakdown, synthesis, and oxidation rates and net protein balance are presented in Figure 3.6. Protein ingestion reduced whole-body protein breakdown rates $(P<0.001)$ and increased whole-body protein synthesis $(P=0.005)$ and oxidation $(P<0.001)$ rates. As a result, whole-body net protein balance increased from $0.5 \pm 0.1$ vs $0.5 \pm 0.2$ $\mu \mathrm{mol} \cdot \mathrm{kg}^{-1} \cdot \mathrm{h}^{-1}$ in the fasted state to $6.8 \pm 0.3$ vs $6.6 \pm 0.4 \mu \mathrm{mol} \cdot \mathrm{kg}^{-1} \cdot \mathrm{h}^{-1}$ in the postprandial state in the $P R O$ vs $P R O+F A T$ treatment, respectively (Time effect $P<0.001$, TimexTreatment $P=0.623$ ). 
Whole-body metabolism

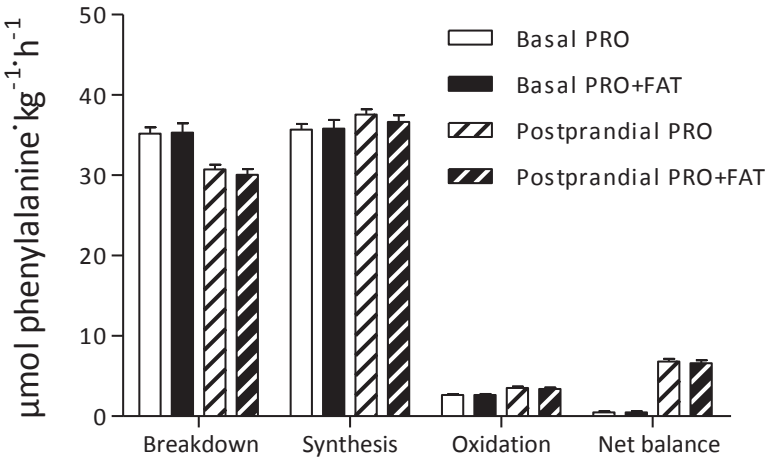

Figure 3.6 | Mean ( \pm SEM) whole-body protein breakdown, synthesis, oxidation, and net balance during the fasting (basal) period and following the ingestion of $20 \mathrm{~g}$ of casein with (PRO+FAT; $\mathrm{n}=12$ ) or without (PRO; $\mathrm{n}=12$ ) $26.7 \mathrm{~g}$ of anhydrous milk fat. Breakdown: Time effect $P<0.001$, TimexTreatment $P=0.363$; Synthesis: Time effect $P=0.005$, TimexTreatment $P=0.264$; Oxidation: Time effect $P<0.001$, TimexTreatment $P=0.454$; Net balance: Time effect $P<0.001$, TimexTreatment $\mathrm{P}=0.623$.

\section{MUSCLE PROTEIN SYNTHESIS}

Myofibrillar protein fractional synthetic rates (FSR) were calculated based on the L-[ring- $\left.{ }^{2} \mathrm{H}_{5}\right]$ phenylalanine (infused tracer, Figure $3.7 \mathrm{~A}$ ) and $\mathrm{L}-\left[1-{ }^{13} \mathrm{C}\right]$-leucine tracer (both infused and ingested tracer, Figure 3.7B). L-[ring- $\left.{ }^{2} \mathrm{H}_{5}\right]$-phenylalanine FSR did not differ between the PRO and PRO+FAT treatment during the early $(P=0.253)$, late $(P=0.232)$, or entire $5 \mathrm{~h}$ postprandial period $(P=0.933)$. In agreement, $\mathrm{L}-\left[1-{ }^{13} \mathrm{C}\right]$-leucine based $\mathrm{FSR}$ did not differ between treatments during the early $(P=0.312)$, late $(P=0.950)$, or entire postprandial period $(P=0.480)$. Basal muscle protein synthesis rates based on the $\mathrm{L}-\left[\right.$ ring- $\left.{ }^{2} \mathrm{H}_{5}\right]$-phenylalanine and $\mathrm{L}-\left[1-{ }^{13} \mathrm{C}\right]$-leucine tracer averaged $0.035 \pm 0.003$ vs $0.031 \pm 0.003 \% \cdot h^{-1}(P=0.356)$ and $0.043 \pm 0.006$ vs $0.032 \pm 0.006 \% \cdot h^{-1}(P=0.206)$ in the PRO vs PRO+FAT treatment, respectively. Although muscle protein synthesis rates assessed over the entire (0-5 h) postprandial period did not significantly differ from basal when FSR was calculated using the $\mathrm{L}-\left[\right.$ ring- $\left.{ }^{2} \mathrm{H}_{5}\right]$-phenylalanine tracer $(\mathrm{P}=0.373)$, the FSR calculated using the $\mathrm{L}-\left[1-{ }^{13} \mathrm{C}\right]$-leucine tracer revealed that protein ingestion tended to increase muscle protein synthesis rates from basal values $(P=0.065)$. This was supported by the increase in myofibrillar protein-bound $L-\left[1-{ }^{13} \mathrm{C}\right]$ phenylalanine (ingested tracer) enrichments over time $(P<0.001)$, which tended to be greater in the PRO when compared with PRO+FAT treatment $(P=0.075$; Figure 3.7C). FSR calculated based on the $\mathrm{L}-\left[1-{ }^{13} \mathrm{C}\right]$-phenylalanine tracer averaged $0.049 \pm 0.006$ vs $0.035 \pm 0.005 \% \cdot \mathrm{h}^{-1}$ during the early $(\mathrm{P}=0.070)$ and $0.050 \pm 0.005$ vs $0.042 \pm 0.003 \% \cdot \mathrm{h}^{-1}$ during the entire $5 \mathrm{~h}$ postprandial period $(P=0.150)$ in the $P R O$ vs $P R O+F A T$ treatment, respectively. 
A

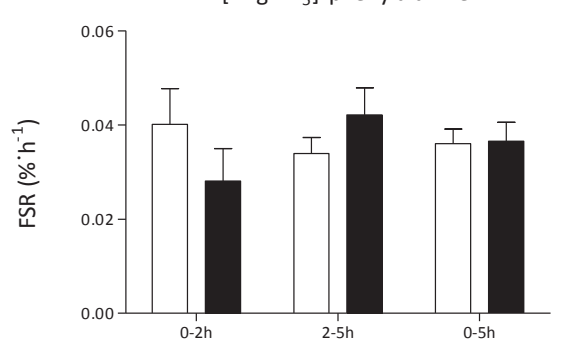

B

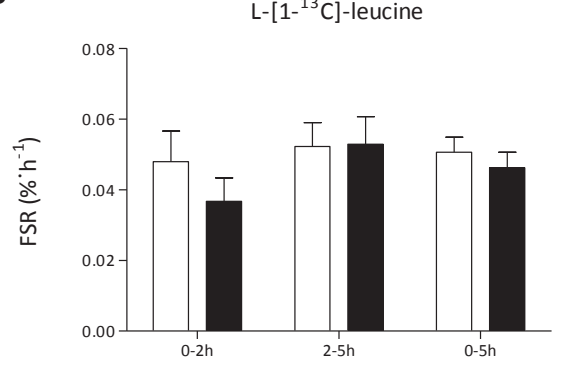

C

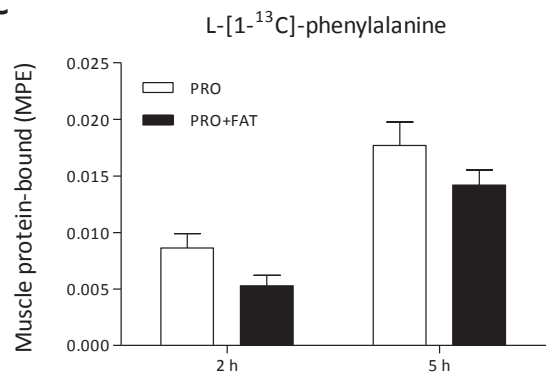

Figure 3.7 | Mean $\left( \pm\right.$ SEM) myofibrillar protein fractional synthetic rates $\left(F S R ; \% \cdot h^{-1}\right)$ based on the $L-\left[r i n g-{ }^{2} \mathrm{H}_{5}\right]-$ phenylalanine $(\mathrm{A})$ and $\mathrm{L}-\left[1-{ }^{13} \mathrm{C}\right]$-leucine $(\mathrm{B})$ tracer and myofibrillar protein-bound $\mathrm{L}-\left[1{ }^{13} \mathrm{C}\right]$-phenylalanine enrichments $(\mathrm{C})$ after the ingestion of $20 \mathrm{~g}$ micellar casein with (PRO+FAT; $n=12$ ) or without (PRO; $n=12) 26.7 \mathrm{~g}$ anhydrous milk fat. L[ring $\left.{ }^{2} \mathrm{H}_{5}\right]$-phenylalanine FSR: $0-2 \mathrm{~h} \mathrm{P}=0.253,2-5$ h P=0.253, 0-5 h P=0.933, TimexTreatment $\mathrm{P}=0.132 ; \mathrm{L}-\left[1-{ }^{13} \mathrm{C}\right]$-leucine FSR: $0-2$ h P $=0.312$, 2-5 h P=0.950, 0-5 h P $=0.480$, TimexTreatment $P=0.499 ; \mathrm{L}-\left[1-{ }^{13} \mathrm{C}\right]$-phenylalanine enrichments: Time effect $\mathrm{P}<0.001$, Treatment effect $\mathrm{P}=0.075$. 


\section{Discussion}

The present study combined the ingestion of intrinsically labeled protein with continuous intravenous infusion of stable isotope-labeled amino acids to assess the impact of co-ingesting milk fat with micellar casein on protein digestion and absorption kinetics and the subsequent postprandial muscle protein synthetic response. We observed that co-ingestion of milk fat does not delay or reduce the appearance of dietary protein-derived amino acids into the circulation and does not affect the postprandial muscle protein synthetic response to micellar casein ingestion in older men.

Several studies have investigated the muscle protein synthetic response to the ingestion of crystalline free amino acids or isolated protein sources $(2,13,23-25)$. However, meals or clinical nutrition products generally contain a combination of all three macronutrients. Therefore, it is important to assess whether carbohydrate or fat co-ingestion modulates dietary protein digestion and absorption and the subsequent postprandial muscle protein synthetic response. Here, we extend on our previous work on carbohydrate co-ingestion (4) and show that co-ingestion of milk fat with micellar casein tends to reduce the appearance rates of dietary-protein derived phenylalanine into the circulation during the early postprandial period. However, we did not observe impairments in the release of dietary-protein derived phenylalanine into the circulation over the entire $5 \mathrm{~h}$ postprandial period. In agreement, postprandial dietary protein-derived phenylalanine availability over the $5 \mathrm{~h}$ postprandial period did not differ between treatments $(52 \pm 2$ vs $52 \pm 3 \%$ in the PRO and PRO+FAT treatment, respectively; $P=0.868)$.

In this study, we hypothesized that co-ingestion of milk fat would slow down gastric emptying and, as such, delay or reduce dietary protein digestion and absorption. However, we did not observe impairments in the availability of dietary protein-derived amino acids in the circulation following co-ingestion of milk fat (Figure 4A). The absence of a delay or decline in the release of dietary-protein derived phenylalanine into the circulation may be attributed to layering of fat on top of protein (and not mixing) in the stomach $(26,27)$. Such an effect would not interfere with protein digestion and absorption and the subsequent appearance of amino acids into the bloodstream. The suggestion that layering of fat on top of protein in the stomach prevents a delay in dietary protein digestion and absorption is supported by previous work (28). Specifically, Gentilcore et al. (28) showed that fat slows down gastric emptying only when ingested $30 \mathrm{~min}$ prior to the meal as opposed to within the meal. However, layering of fat on top of protein in the stomach may only occur in a liquid meal (27). The effect of fat co-ingestion within a solid protein meal on protein digestion and absorption and the subsequent muscle protein synthetic response remains to be established.

The use of intrinsically labeled dietary protein in combination with contemporary stable isotope methodology not only allowed for assessing the rate at which dietary protein-derived amino acids appear into the circulation, but also to evaluate myofibrillar protein synthesis rates and the metabolic fate of dietary protein-derived amino acids (14). Myofibrillar protein synthesis rates over the early $0-2 \mathrm{~h}$ postprandial period assessed using either the L-[ring- $\left.{ }^{2} \mathrm{H}_{5}\right]$-phenylalanine or $\mathrm{L}-\left[1-{ }^{13} \mathrm{C}\right]-$ leucine tracer did not significantly differ between treatments (Figure $5 \mathrm{~A}$ and $\mathrm{B}$ ). The incorporation of dietary protein-derived amino acids into myofibrillar protein (i.e., muscle protein-bound L-[1${ }^{13} \mathrm{C}$ ]-phenylalanine enrichments) tended to be lower during the early postprandial period when milk fat was co-ingested (Figure 5C). However, no differences were observed in myofibrillar protein synthesis rates or the postprandial rise in dietary protein-derived $\mathrm{L}-\left[1-{ }^{13} \mathrm{C}\right]$-phenylalanine enrichments in myofibrillar protein when assessed over the entire $5 \mathrm{~h}$ postprandial period. Consequently, we show that co-ingestion of milk fat with micellar casein does not modulate the 
myofibrillar protein synthetic response to protein ingestion in older males. We chose to use micellar casein in our previous work (4) as well as the present study since milk protein contains nearly $80 \%$ casein. Casein has been identified as a 'slow' protein as it coagulates in the stomach resulting in a sustained aminoacidemia when compared with whey protein (12). As such, it could be speculated that the speed of digestion and absorption of micellar casein could not be further reduced and thus minimized the potential of fat co-ingestion with protein to modulate dietary protein digestion and absorption kinetics. However, we have previously shown that carbohydrate co-ingestion with micellar casein delays the release of dietary-protein derived phenylalanine into the circulation in healthy young and older adults (4). Here, we did not observe such an effect when milk fat was co-ingested with micellar casein despite the energy content of the treatment beverages being identical ( $240 \mathrm{kcal})$ to our previous work (4). Nonetheless, there is potential that reducing the speed of protein digestion and absorption by macronutrient co-ingestion with a more rapidly digestible protein, such as whey protein, may affect postprandial muscle protein synthesis rates.

In line with the absence of any substantial delay or decline in the release of dietary-protein derived phenylalanine into the circulation, we did not observe any negative impact of co-ingesting milk fat on postprandial muscle protein synthesis rates or the effectiveness by which dietary proteinderived amino acids were being used for de novo myofibrillar protein synthesis (Figure 5). We also did not observe any potential stimulatory effect of fat co-ingestion on postprandial muscle protein synthesis rates. Previously, Elliot et al. (8) demonstrated that the ingestion of whole milk during recovery from exercise results in greater net amino acid uptake over the leg when compared with the ingestion of fat-free milk. The greater energy intake in the form of fat may have been responsible for a greater use of amino acids for muscle protein synthesis during recovery from an exhaustive bout of exercise. Nonetheless, the proposed stimulatory effects of fat co-ingestion on muscle anabolism do not seem to be of relevance within the constraints of the presented study design.

From a practical standpoint, clinical conditions in which food intake is compromised are generally characterized by the loss of skeletal muscle mass. The loss of skeletal muscle mass represents a predictor for mortality and morbidity rates in the older population (29-31). Therefore, it is of considerable clinical relevance to develop effective dietary strategies to preserve skeletal muscle mass. Protein intake has been shown to stimulate muscle protein synthesis, thereby providing potential in attenuating the loss of skeletal muscle mass (32). Clinical nutrition products generally provide all three macronutrients. In line with our previous work investigating the impact of carbohydrate co-ingestion with protein (4) we show that fat co-ingestion does not impair or enhance the muscle protein synthetic response to protein ingestion. Therefore, protein dense clinical nutrition products with reduced amounts of fat may provide an effective strategy to prevent or attenuate the loss of skeletal muscle mass in conditions in which total energy intake is compromised.

In conclusion, co-ingestion of milk fat with micellar casein does not impair the release of dietaryprotein derived phenylalanine into the circulation and does not modulate subsequent postprandial myofibrillar protein synthesis rates in healthy older males. These findings indicate that dietary protein supplementation does not require co-ingestion of fat to optimize postprandial muscle protein accretion. 


\section{REFERENCES}

1. Cuthbertson D, Smith K, Babraj J, Leese G, Waddell T, Atherton P, Wackerhage H, Taylor PM, Rennie MJ. Anabolic signaling deficits underlie amino acid resistance of wasting, aging muscle. Faseb J 2005;19(3):422-4.

2. Katsanos CS, Kobayashi $H$, Sheffield-Moore M, Aarsland A, Wolfe RR. Aging is associated with diminished accretion of muscle proteins after the ingestion of a small bolus of essential amino acids. Am J Clin Nutr 2005;82(5):1065-73.

3. Burd NA, Gorissen SH, van Loon LJ. Anabolic resistance of muscle protein synthesis with aging. Exercise and sport sciences reviews 2013;41(3):169-73.

4. Gorissen SH, Burd NA, Hamer HM, Gijsen AP, Groen BB, van Loon LJ. Carbohydrate co-ingestion delays dietary protein digestion and absorption but does not modulate postprandial muscle protein accretion. J Clin Endocrinol Metab 2014:jc20133970.

5. Boirie Y, Gachon P, Beaufrere B. Splanchnic and whole-body leucine kinetics in young and elderly men. Am J Clin Nutr 1997;65(2):489-95.

6. Timmerman KL, Lee JL, Fujita S, Dhanani S, Dreyer HC, Fry CS, Drummond MJ, Sheffield-Moore M, Rasmussen BB, Volpi E. Pharmacological vasodilation improves insulin-stimulated muscle protein anabolism but not glucose utilization in older adults. Diabetes 2010;59(11):2764-71.

7. Dickinson JM, Drummond MJ, Coben JR, Volpi E, Rasmussen BB. Aging differentially affects human skeletal muscle amino acid transporter expression when essential amino acids are ingested after exercise. Clin Nutr 2013;32(2):273-80.

8. Elliot TA, Cree MG, Sanford AP, Wolfe RR, Tipton KD. Milk ingestion stimulates net muscle protein synthesis following resistance exercise. Med Sci Sports Exerc 2006;38(4):667-74.

9. Calbet JA, MacLean DA. Role of caloric content on gastric emptying in humans. J Physiol 1997;498 (Pt 2):553-9.

10. Fouillet H, Gaudichon C, Mariotti F, Bos C, Huneau JF, Tome D. Energy nutrients modulate the splanchnic sequestration of dietary nitrogen in humans: a compartmental analysis. Am J Physiol Endocrinol Metab 2001;281(2):E248-60

11. Svanberg E, Moller-Loswick AC, Matthews DE, Korner U, Andersson M, Lundholm K. The role of glucose, longchain triglycerides and amino acids for promotion of amino acid balance across peripheral tissues in man. Clinical physiology (Oxford, England) 1999;19(4):311-20.

12. Boirie $Y$, Dangin M, Gachon P, Vasson MP, Maubois JL, Beaufrere B. Slow and fast dietary proteins differently modulate postprandial protein accretion. Proc Natl Acad Sci U S A 1997;94(26):14930-5.

13. Pennings $B$, Boirie $Y$, Senden JM, Gijsen AP, Kuipers $H$, van Loon LJ. Whey protein stimulates postprandial muscle protein accretion more effectively than do casein and casein hydrolysate in older men. Am J Clin Nutr 2011;93(5):997-1005.

14. Burd NA, Cermak NM, Kouw IW, Gorissen SH, Gijsen AP, van Loon LJ. The use of doubly labeled milk protein to measure postprandial muscle protein synthesis rates in vivo in humans. Journal of applied physiology (Bethesda, Md : 1985) 2014;117(11):1363-70.

15. Alberti KG, Zimmet PZ. Definition, diagnosis and classification of diabetes mellitus and its complications. Part 1: diagnosis and classification of diabetes mellitus provisional report of a WHO consultation. Diabet Med 1998;15(7):539-53

16. Abumrad NN, Rabin D, Diamond MP, Lacy WW. Use of a heated superficial hand vein as an alternative site for the measurement of amino acid concentrations and for the study of glucose and alanine kinetics in man. Metabolism 1981;30(9):936-40.

17. Bergstrom J. Percutaneous needle biopsy of skeletal muscle in physiological and clinical research. Scand J Clin Lab Invest 1975;35(7):609-16.

18. Burd NA, Hamer HM, Pennings B, Pellikaan WF, Senden JM, Gijsen AP, van Loon LJ. Substantial Differences between Organ and Muscle Specific Tracer Incorporation Rates in a Lactating Dairy Cow. PLoS One 2013;8(6):e68109.

19. Pennings B, Pellikaan WF, Senden JM, van Vuuren AM, Sikkema J, van Loon LJ. The production of intrinsically labeled milk and meat protein is feasible and provides functional tools for human nutrition research. J Dairy Sci 2011;94(9):4366-73.

20. van Loon LJ, Boirie Y, Gijsen AP, Fauquant J, de Roos AL, Kies AK, Lemosquet S, Saris WH, Koopman R. The production of intrinsically labeled milk protein provides a functional tool for human nutrition research. J Dairy Sci 2009;92(10):4812-22.

21. Boirie Y, Gachon P, Corny S, Fauquant J, Maubois JL, Beaufrere B. Acute postprandial changes in leucine metabolism as assessed with an intrinsically labeled milk protein. Am J Physiol 1996;271(6 Pt 1):E1083-91.

22. Dangin M, Guillet C, Garcia-Rodenas C, Gachon P, Bouteloup-Demange C, Reiffers-Magnani K, Fauquant J, Ballevre $\mathrm{O}$, Beaufrere $\mathrm{B}$. The rate of protein digestion affects protein gain differently during aging in humans. J Physiol 2003;549(Pt 2):635-44.

23. Glynn EL, Fry CS, Timmerman KL, Drummond MJ, Volpi E, Rasmussen BB. Addition of Carbohydrate or Alanine to an Essential Amino Acid Mixture Does Not Enhance Human Skeletal Muscle Protein Anabolism. J Nutr 2013.

24. Katsanos CS, Aarsland A, Cree MG, Wolfe RR. Muscle protein synthesis and balance responsiveness to essential amino acids ingestion in the presence of elevated plasma free fatty acid concentrations. J Clin Endocrinol Metab 2009;94(8):2984-90. 
25. Pennings B, Groen B, de Lange A, Gijsen AP, Zorenc AH, Senden JM, van Loon LJ. Amino acid absorption and subsequent muscle protein accretion following graded intakes of whey protein in elderly men. Am J Physiol Endocrinol Metab 2012;302(8):E992-9.

26. Houghton LA, Mangnall YF, Read NW. Effect of incorporating fat into a liquid test meal on the relation between intragastric distribution and gastric emptying in human volunteers. Gut 1990;31(11):1226-9.

27. Edelbroek M, Horowitz M, Maddox A, Bellen J. Gastric emptying and intragastric distribution of oil in the presence of a liquid or a solid meal. J Nucl Med 1992;33(7):1283-90.

28. Gentilcore D, Chaikomin R, Jones KL, Russo A, Feinle-Bisset C, Wishart JM, Rayner CK, Horowitz M. Effects of fat on gastric emptying of and the glycemic, insulin, and incretin responses to a carbohydrate meal in type 2 diabetes. J Clin Endocrinol Metab 2006;91(6):2062-7.

29. Janssen I, Heymsfield SB, Ross R. Low relative skeletal muscle mass (sarcopenia) in older persons is associated with functional impairment and physical disability. Journal of the American Geriatrics Society 2002;50(5):88996.

30. Kimyagarov S, Klid R, Fleissig Y, Kopel B, Arad M, Adunsky A. Skeletal muscle mass abnormalities are associated with survival rates of institutionalized elderly nursing home residents. The journal of nutrition, health \& aging 2012;16(5):432-6.

31. Landi F, Liperoti R, Fusco D, Mastropaolo S, Quattrociocchi D, Proia A, Tosato M, Bernabei R, Onder G. Sarcopenia and mortality among older nursing home residents. J Am Med Dir Assoc 2012;13(2):121-6.

32. Houston DK, Nicklas BJ, Ding J, Harris TB, Tylavsky FA, Newman AB, Lee JS, Sahyoun NR, Visser M, Kritchevsky SB. Dietary protein intake is associated with lean mass change in older, community-dwelling adults: the Health, Aging, and Body Composition (Health ABC) Study. Am J Clin Nutr 2008;87(1):150-5. 


\section{WFUSION CASEIN
INTRINSICALIYLABELED
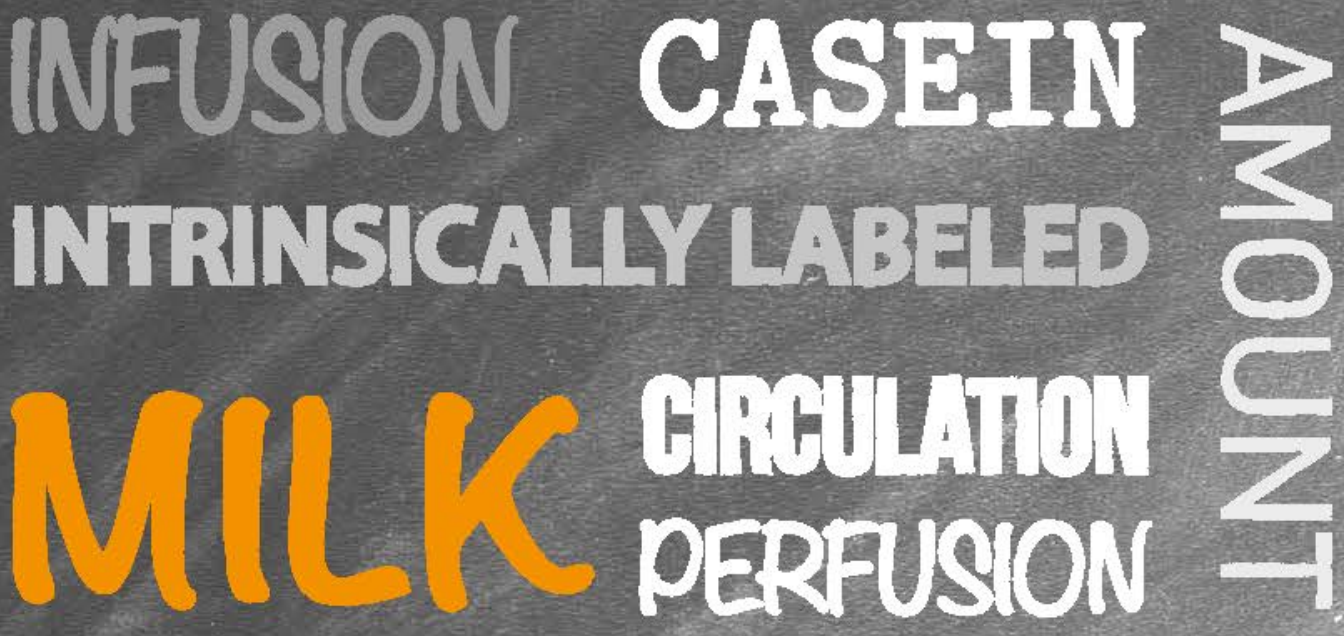
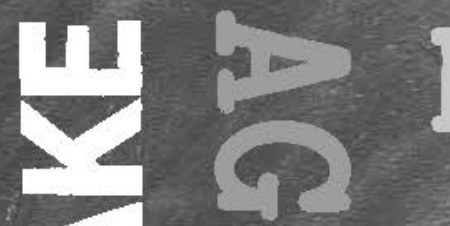

9

$-1$

1

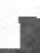

t-

DIFIART

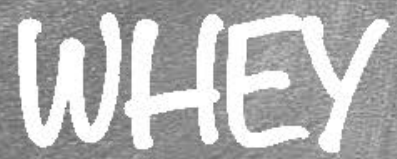

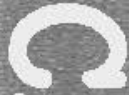

$4-1$

$\Leftrightarrow$

(a)

26 \&

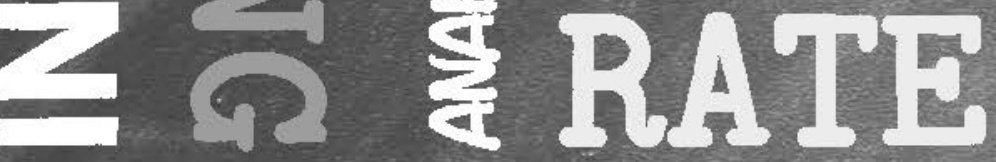

\section{AGE}

LI AMINO ACD

() HMROLYSATE 0
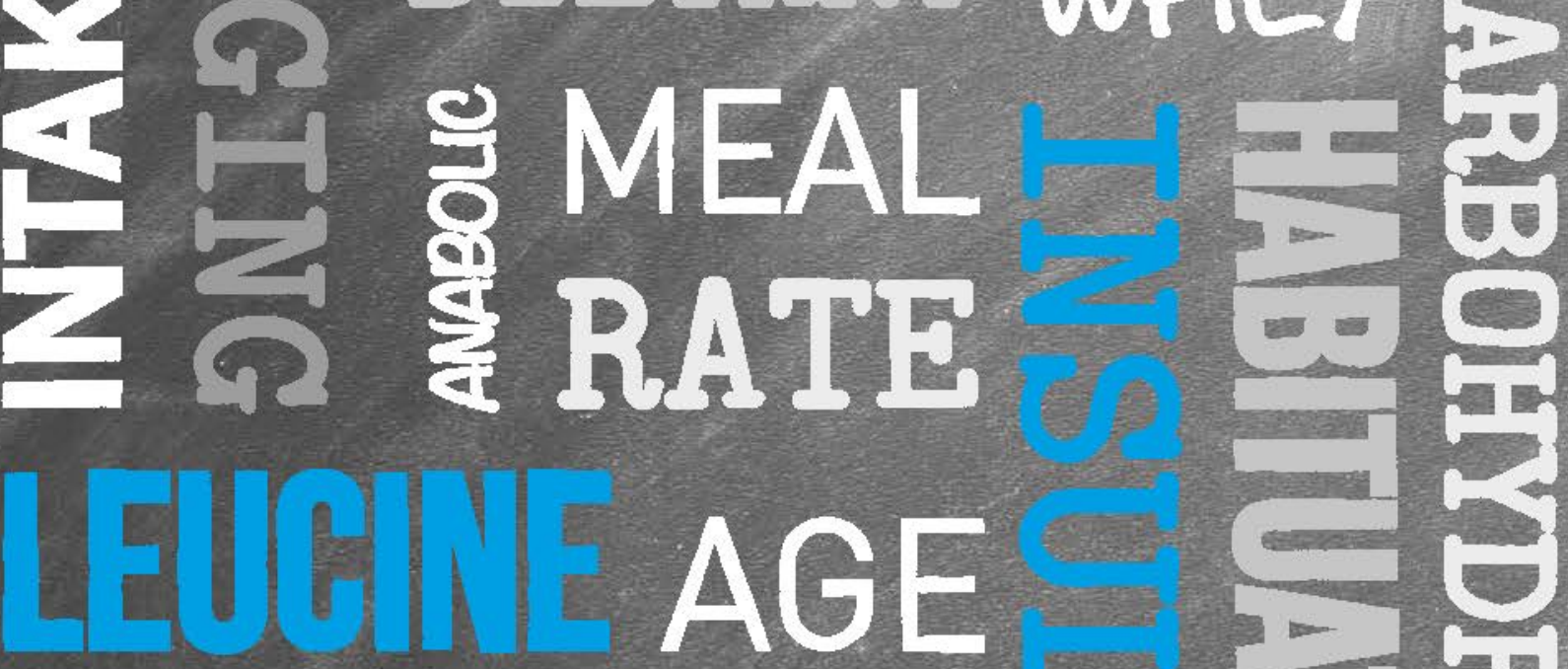



\section{ABSTRACT}

BACKGROUND: Protein consumed after resistance exercise increases post-exercise muscle protein synthesis rates. To date, dairy protein has been studied extensively with only little known about the capacity of other protein dense foods to augment post-exercise muscle protein synthesis rates. OBJECTIVE: We aimed to compare protein digestion and absorption kinetics, postprandial amino acid availability, anabolic signaling, and the subsequent myofibrillar protein synthetic response after the ingestion of milk versus beef during recovery from resistance type exercise.

DESIGN: In crossover trials, 12 healthy, young males performed a single bout of resistance exercise. Immediately after cessation of exercise, participants ingested $30 \mathrm{~g}$ protein by consuming isonitrogenous amounts of intrinsically $L-\left[1-{ }^{13} \mathrm{C}\right]$-phenylalanine labeled beef or milk. Blood and muscle biopsy samples were collected at rest and after exercise during primed continuous infusions of $\mathrm{L}$-[ring- ${ }^{2} \mathrm{H}_{5}$ ]-phenylalanine and $\mathrm{L}$-[ring-3,5- ${ }^{2} \mathrm{H}_{2}$ ]-tyrosine to assess protein digestion and absorption kinetics, plasma amino acid availability, anabolic signaling, and subsequent myofibrillar protein synthesis rates in vivo in young males.

RESULTS: Beef protein-derived phenylalanine appeared more rapidly in circulation when compared to milk ingestion $(P<0.001)$. The availability of phenylalanine during the $5 \mathrm{~h}$ post-exercise period tended to be higher after beef $(64 \pm 3 \%)$ when compared to milk ingestion $(57 \pm 3 \% ; P=0.08)$. Both beef and milk ingestion were followed by an increase in the phosphorylation of mammalian target of rapamycin complex 1 and $70 \mathrm{kDa}$ S6 protein kinase 1 during post-exercise recovery. Milk ingestion increased myofibrillar protein synthesis rates to a greater extent than beef ingestion during the $0-2 \mathrm{~h}$ post-exercise phase $(P=0.013)$. However, the increase in myofibrillar protein synthesis rates did not differ between milk and beef ingestion during the entire $0-5 \mathrm{~h}$ post-exercise phase $(P=0.114)$.

CONCLUSION: Both milk and beef ingestion augments the post-exercise myofibrillar protein synthetic response in young males with a stronger stimulation of myofibrillar protein synthesis during the early postprandial stage after milk ingestion. 


\section{INTRODUCTION}

The postprandial muscle protein synthetic response to protein ingestion has been shown to be modulated by dietary protein digestion and absorption kinetics $(1,2)$ and the amino acid composition $(2,3)$ of the ingested protein source. Both of these variables have been shown to affect the postprandial rise in circulating leucine concentrations and (essential) amino acid availability, thereby modulating the postprandial increase in muscle protein synthesis rates $(2,3)$. Studies that have investigated the postprandial or post-exercise muscle protein synthetic response after the ingestion of various protein sources have mainly used isolated dairy (whey and casein) or soy proteins (2-5). However, the consumption of specific isolated protein sources (e.g., isolated protein powders) is not general practice as protein dense foods, such as dairy milk or meat, are more commonly consumed. The consumption of whole foods implies that the protein is consumed within a specific food matrix with other macronutrients being available. Recent work has shown that carbohydrate co-ingestion with protein can modulate digestion and absorption kinetics when compared to ingesting protein only (6). Such observations underline the necessity of studying digestion and amino acid absorption kinetics and the subsequent postprandial muscle protein synthetic response after the ingestion of protein dense foods, as opposed to the ingestion of merely isolated protein fractions. Milk and beef are common protein dense foods that are consumed within the Western diet and responsible for providing a large percentage of daily protein intake $(7,8)$. Interestingly, little research has been performed that assesses dietary protein digestion and absorption kinetics after the ingestion of dietary protein within its natural food matrix. Furthermore, no study has directly compared the muscle protein synthetic response to the ingestion of high quality animal-derived proteins such as milk versus beef.

This study compares protein digestion and absorption kinetics and the subsequent myofibrillar protein synthetic response after the ingestion of milk and beef during recovery from resistance type exercise in young males. To provide a mechanistic basis for the regulation of myofibrillar protein synthesis after food ingestion during post-exercise recovery, we also examined the phosphorylation status of key proteins involved in nutrient sensing and muscle anabolic signaling. To our knowledge, this is the first study to assess protein digestion and amino acid absorption kinetics and the subsequent postprandial myofibrillar protein synthetic response after the ingestion of two of the main protein dense foods (milk and beef) commonly found in the western diet in vivo in humans. 


\section{MetHODS}

\section{PARTICIPANTS AND ETHICAL APPROVAL}

Twelve healthy young men (age: $22 \pm 1$ y, body weight: $74 \pm 3 \mathrm{~kg}$, body fat $\%: 13 \pm 1 \%$, BMl: $22 \pm 0.4$ $\mathrm{kg} \cdot \mathrm{m}^{-2}$ ) volunteered to participate in this study. Participants were recreationally active and engaged in exercise at least 2 times per week for $\geq 1 \mathrm{y}$. All participants were deemed healthy based on their response to a routine medical screening questionnaire. Participants were informed of the purpose of the study, experimental procedures, and all its potential risks prior to providing written consent to participate. Participants had no prior history of participating in stable isotope amino acid tracer experiments. The study was approved by the Medical Ethics Committee of the Maastricht University Medical Centre+, Maastricht, the Netherlands and conformed to standards for the use of human participants in research as outlined in the sixth Declaration of Helsinki.

\section{EXPERIMENTAL DESIGN}

A within-subject cross-over design was used for this study. Two weeks prior to the infusion trials, participants reported to the laboratory for familiarization with the exercise equipment and for maximum strength tests as determined by their one repetition maximum (1RM) for leg press $(217 \pm 12 \mathrm{~kg})$ and knee extension exercise $(132 \pm 8 \mathrm{~kg})$. In addition, body weight and height were measured as well as body composition by dual-energy X-ray absorptiometry (Discovery A; Hologic Corp, Bedford, MA). Participants were instructed to refrain from vigorous physical activity for three days prior to each tracer infusion and to report their dietary intake in a food diary for two days prior to each infusion trial (Table 4.1). All participants consumed a standardized meal of the same composition (32 $\pm 1 \mathrm{~kJ}^{\mathrm{kg}} \mathrm{kg}^{-1}$ body weight: providing 33 energy\% (En\%) carbohydrate, $51 \mathrm{En} \%$ fat, and $16 \mathrm{En} \%$ of protein) the evening prior to each tracer infusion trial. Participants were randomly assigned to consume skim milk or an isonitrogenous amount of minced beef during two subsequent infusion trials. The time between crossover trials was 8-20 days (14 $\pm 1 \mathrm{~d})$. Upon completion of the first infusion trial, a copy of the food diary was returned to the participants and they were subsequently instructed to maintain their previously recorded dietary habits in the two days leading into the second infusion trial.

Table 4.1 | Self-reported dietary intake during two days prior to the infusion trial

\begin{tabular}{lccc}
\hline & Milk & Beef & P value \\
\hline Energy $\left(\mathrm{kcal} \cdot \mathrm{d}^{-1}\right)$ & $2603 \pm 219$ & $2676 \pm 250$ & 0.83 \\
Energy $\left(\mathrm{MJ} \cdot \mathrm{d}^{-1}\right)$ & $10.9 \pm 0.9$ & $11.2 \pm 1.0$ & 0.83 \\
Protein (En\%) & $17 \pm 1$ & $20 \pm 2$ & 0.28 \\
Carbohydrate (En\%) & $49 \pm 3$ & $47 \pm 4$ & 0.68 \\
Fat (En\%) & $34 \pm 2$ & $34 \pm 3$ & 0.93 \\
\hline
\end{tabular}

\section{INFUSION PROTOCOL}

On the trial days, the participants reported to the laboratory at $0800 \mathrm{~h}$ after an overnight fast. A Teflon catheter was inserted into an antecubital vein in the hand and placed in a hot-box $\left(60^{\circ} \mathrm{C}\right)$ for arterialized blood sampling. After baseline blood sample collection ( $\mathrm{t}=-240 \mathrm{~min}$ ), the plasma phenylalanine and tyrosine pools were primed with a single intravenous dose of L-[ring- $\left.{ }^{2} \mathrm{H}_{5}\right]-$ phenylalanine $\left(2 \mu \mathrm{mol} \cdot \mathrm{kg}^{-1}\right)$ and L-[ring-3,5- $\left.{ }^{2} \mathrm{H}_{2}\right]$-tyrosine $\left(0.615 \mu \mathrm{mol} \cdot \mathrm{kg}^{-1}\right)$. Subsequently, an intravenous infusion of $\mathrm{L}-\left[\mathrm{ring}_{-}{ }^{2} \mathrm{H}_{5}\right]$-phenylalanine (infusion rate of $0.05 \mu \mathrm{mol} \cdot \mathrm{kg}^{-1} \cdot \mathrm{min}^{-1}$ ) and L- 
[ring-3,5- ${ }^{2} \mathrm{H}_{2}$ ]-tyrosine $\left(0.15 \mu \mathrm{mol} \cdot \mathrm{kg}^{-1} \cdot \mathrm{min}^{-1}\right)$ was initiated and maintained until the end of the trial. To minimize the number of biopsies collected and to provide a reference value for the assessment of post-absorptive myofibrillar protein synthesis rates (9-11), a single resting muscle biopsy was collected after $180 \mathrm{~min}$ of infusion. Afterwards, the participants performed resistance type exercise that consisted of 4 sets of 8-10 repetitions to volitional fatigue for both the leg press and knee extension exercise ( $t=-60 \mathrm{~min}$ ). After the completion of the exercise bout, a muscle biopsy was collected and subsequently the participants consumed $158 \mathrm{~g}$ (providing $30 \mathrm{~g}$ of protein) minced beef or an isonitrogenous amount of non-fat skim milk ( $t=0 \mathrm{~min}$; Table 4.2). Additional muscle biopsies were obtained after 2 and $5 \mathrm{~h}$ of post-exercise recovery. Arterialized blood samples were drawn every 30 or $60 \mathrm{~min}$ during the post-absorptive and postprandial states. The exercise external work (repetitions $\times$ load) was matched between the first $(\sim 9400 \mathrm{~kg})$ and second trial $(\sim 9300 \mathrm{~kg})$. The biopsies were collected from the middle region of the vastus lateralis $(15 \mathrm{~cm}$ above the patella) through separate incisions with a Bergström needle under local anesthesia. On each trial, the first resting biopsy was obtained from one leg (randomized) and the three post-exercise biopsies were obtained from the contralateral leg. All biopsy samples were freed from any visible adipose tissue and blood, immediately frozen in liquid nitrogen, and stored at $-80^{\circ} \mathrm{C}$ until subsequent analysis.

Table 4.2 | Macronutrient and energy composition of the ingested meals

\begin{tabular}{lcc}
\hline & Skim milk & Minced Beef \\
\hline Protein, $g$ & 30 & 30 \\
EAAs, g & & 1.59 \\
$\quad$ Isoleucine & 1.65 & 2.48 \\
Leucine & 2.71 & 2.81 \\
Lysine & 2.24 & 0.79 \\
$\quad$ Methionine & 0.71 & 1.43 \\
$\quad$ Phenylalanine & 1.37 & 1.21 \\
$\quad$ Threonine & 1.20 & 1.59 \\
$\quad$ Valine & 1.85 & 1.11 \\
Histidine & 0.81 & 13 \\
EEAAs, g & 13 & 8.9 \\
Leucine by total amino acids, $\%$ & 10.6 & 0.7 \\
Carbohydrate, g & 30.8 & 4.6 \\
Fat, g & 0.4 & 164
\end{tabular}

Amounts are shown per bolus ( $350 \mathrm{~mL}$ milk vs $158 \mathrm{~g}$ beef). EAA, essential amino acid. $\Sigma$ EAAs include lle, Leu, Lys, Met, Phe, Thr, Val, and His. Trp was not measured.

\section{MEAL COMPOSITION}

The intrinsically labeled beef and milk was obtained by the infusion of $\mathrm{L}-\left[1-{ }^{13} \mathrm{C}\right]$-phenylalanine into a lactating Holstein cow as described previously (12). The beef was minced prior to packaging and stored at $-18^{\circ} \mathrm{C}$. Prior to the infusion, the minced beef was thawed overnight in a refrigerator at $4^{\circ} \mathrm{C}$. The minced beef was prepared into a patty $(158 \mathrm{~g})$ and grilled until the inner temperature reached $65^{\circ} \mathrm{C}$. The $158 \mathrm{~g}$ minced beef patty provided $30 \mathrm{~g}$ protein intrinsically labeled with $\mathrm{L}-\left[1-{ }^{13} \mathrm{C}\right]-$ 
phenylalanine at an enrichment of 1.7 mole percent excess (MPE). The milk (skim milk powder, FrieslandCampina, the Netherlands) was enriched to match the $\mathrm{L}-\left[1-{ }^{13} \mathrm{C}\right]$-phenylalanine of the beef (1.7 MPE) by using a $20 / 80$ mixture of intrinsically L- $\left[1-{ }^{13} \mathrm{C}\right]$-phenylalanine labeled whey and casein, respectively, in a total volume of $350 \mathrm{~mL}$. The energy content and macronutrient composition are provided in Table 4.2 .

\section{PLASMA ANALYSES}

Plasma glucose and insulin concentrations were analyzed using commercially available kits (Glucose HK Gen.3, reference: 05168791190 (Roche) and Insulin, reference: 12017547122 (Roche)). Plasma amino acid concentrations and enrichments were determined by gas chromatographymass spectrometry analysis (GC-MS; Agilent 7890A GC/5975C; MSD, Little Falls, DE) as previously described (6).

\section{WESTERN BLOTTING}

Phosphorylation status of mammalian target of rapamycin complex 1 (mTORC1) at Ser2448, 70 kDa S6 protein kinase 1 (p70S6K1) at Thr389, eukaryotic translation initiation factor 4E-binding protein 1 (4E-BP1) at Thr37/46, and ribosomal protein S6 (rpS6) at Ser240/244 were quantified relative to total protein content as described in our previous work using antibodies from Cell Signaling (13).

\section{MYOFIBRILLAR PROTEIN SYNTHESIS}

Myofibrillar protein enriched fractions were isolated as described in our previous work (14). Myofibrillar protein bound enrichments were determined by GC-MS analysis. To reduce the signalto-noise ratio during GC-MS analysis at low tracer enrichments, the phenylalanine from the myofibrillar protein hydrolysates were enzymatically decarboxylated to $\beta$-phenylethylamine (15) prior to tert-butyldimethylsilyl (tBDMS) derivatization $(16,17)$. Enrichments of the protein bound samples were determined by selected ion monitoring for $\beta$-phenylethylamine-tBDMS mass to charge ratio at $183(m+5)$ to $180(m+2)$ and a single linear standard curve (to avoid slope influences on the measured enrichment) from mixtures of known $m+5$ to $m+2$ ratios. To avoid saturation of the mass spectrometer and eliminate bias due to any potential concentration dependencies (18), the split ratio was adjusted prior to the injection of each sample so that nearly equal amounts of phenylalanine were injected for all samples and standards.

\section{CALCULATIONS}

Whole-body amino acid kinetics were assessed in non-steady conditions by the ingestion of intrinsically L- $\left[1-{ }^{13} \mathrm{C}\right]$-phenylalanine labeled milk and beef combined with the intravenous infusion of L-[ring- ${ }^{2} \mathrm{H}_{5}$-phenylalanine and $\mathrm{L}$-[ring-3,5- $\left.{ }^{2} \mathrm{H}_{2}\right]$-tyrosine. Total, exogenous, and endogenous phenylalanine rate of appearance $\left(R_{a}\right)$, total rate of disappearance $\left(R_{d}\right)$, and plasma availability of dietary protein-derived phenylalanine (the fraction of the dietary phenylalanine that appeared in systemic circulation, Phe $\left.\mathrm{plasma}_{\text {a }}\right)$ were calculated using modified Steele equations $(19,20)$. The fractional synthetic rates (FSR) of myofibrillar protein were calculated using standard precursorproduct methods by dividing the increment in tracer enrichment in the myofibrillar protein by the enrichment in the plasma precursor pool over time (10). 
STATISTICS

A within-subject cross-over design was used for the study. Differences in myofibrillar protein synthesis, whole body amino acid kinetics, and muscle anabolic signaling were tested by twofactor (treatment $\times$ time) repeated measures analysis of variance (ANOVA). When statistically significant interaction effects were observed, Bonferroni post-hoc tests were performed to locate these differences. A power calculation based on previously research $(2,3)$ indicated that $n=10$ was sufficient to detect differences in the postprandial muscle protein synthetic response to the ingestion of different protein sources when using a two-sided statistical test ( $P<0.05,80 \%$ power). Considering a potential dropout rate of $20 \%$ during the protocol, the final number of participants that were recruited was $n=12$. For all analyses, differences will be considered statistically significant at $P<0.05$. All calculations were performed using IBM SPSS Statistics Version 20. All data are expressed as means \pm SEMs. 


\section{RESULTS}

\section{PLASMA METABOLITES}

Plasma glucose concentrations increased after milk ingestion (Time $\times$ Treatment, $P<0.001$ ). Plasma glucose concentrations reached higher peak values $\left(6.9 \pm 0.3\right.$ vs $\left.5.9 \pm 0.1 \mathrm{mmol} \cdot \mathrm{L}^{-1}\right)$ after milk compared with beef ingestion, respectively ( $P=0.003$; Figure 4.1 A). Plasma insulin concentrations increased after milk ingestion during recovery from exercise $(P<0.001)$. As such, plasma insulin concentrations reached higher peak values of $45 \pm 6 \mathrm{vs} 17 \pm 2 \mathrm{mU} \cdot \mathrm{L}^{-1}$ after milk when compared with beef ingestion, respectively $(P<0.001$; Figure 4.1B).

A

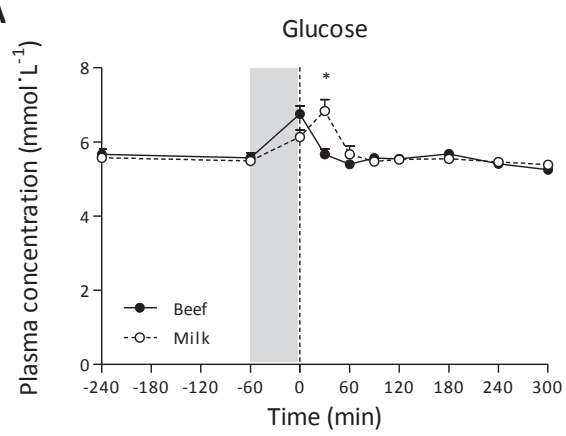

B

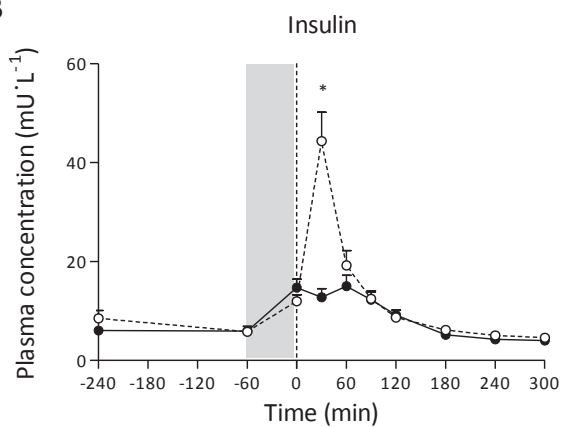

Figure 4.1 | Mean ( \pm SEM) plasma glucose (A) and insulin concentrations (B) (mmol. $\mathrm{L}^{-1}$ and $\mathrm{mU} \cdot \mathrm{L}^{-1}$, respectively) in the fasting state and after consumption of beef or milk in young men $(n=12)$. Grey area corresponds to the exercise bout; dashed line refers to protein ingestion. * Treatment conditions differ at these time points. Data were analyzed with twofactor repeated measures ANOVA with time and treatment as within subject factors. A Bonferroni post hoc test was used to locate differences between means for all statistically significant interactions. Glucose: Time effect $P<0.001$, Time $\times$ Treatment $P<0.001$. Insulin: Time effect $P<0.001$, Time $\times$ Treatment $P<0.001$. Beef, minced beef. Milk, skim milk.

Plasma phenylalanine concentrations rapidly increased after milk and beef ingestion $(P<0.001)$, with plasma phenylalanine concentrations reaching higher peak values after beef when compared with milk ingestion ( $80 \pm 2$ vs $73 \pm 2 \mathrm{mmol} \cdot \mathrm{L}^{-1}$, respectively; $P<0.001$; Figure $\left.4.2 \mathrm{~A}\right)$. Plasma leucine concentrations rapidly increased after milk and beef ingestion $(P<0.001)$. Plasma leucine concentrations showed a more rapid increase during the first $30 \mathrm{~min}$ after milk when compared with beef ingestion. However, plasma leucine concentrations reached peak values of $277 \pm 12$ and $231 \pm 11 \mu \mathrm{mol} \cdot \mathrm{L}^{-1}(P=0.002)$ at $115 \pm 8$ and $135 \pm 26 \mathrm{~min}$ after beef and milk ingestion, respectively (Figure 4.2C). Plasma tyrosine concentrations transiently increased after protein ingestion $(P<0.001)$. The postprandial rise in tyrosine concentrations was greater after beef when compared with milk ingestion (Time $\times$ Treatment: $P<0.001$; Figure 4.2B). 
A

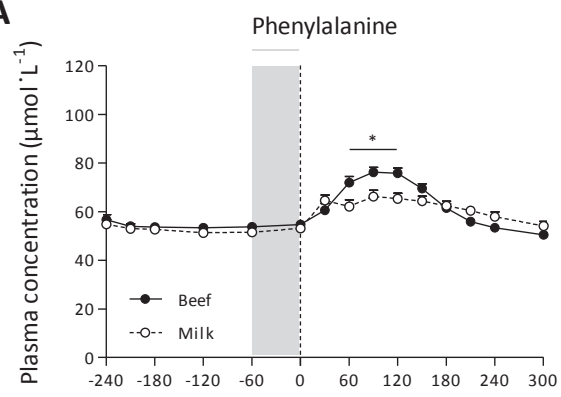

C

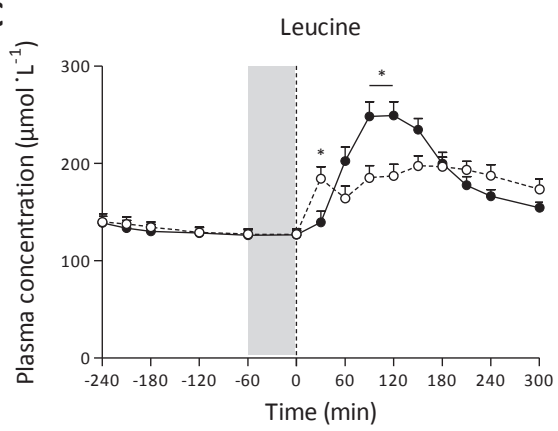

B

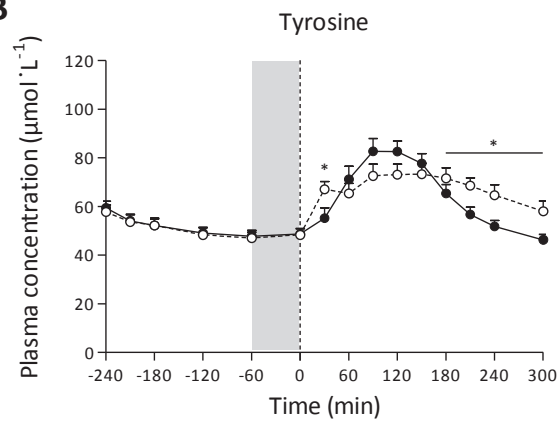

Figure 4.2 Mean ( \pm SEM) plasma phenylalanine (A), tyrosine (B), and leucine concentrations $(C)\left(\mu \mathrm{mol} \cdot \mathrm{L}^{-1}\right)$ in the fasting state and after consumption of beef or milk in young men $(n=12)$. Grey area corresponds to the exercise bout; dashed line refers to protein ingestion. * Treatment conditions differ at these time points. Data were analyzed with two-factor repeated measures ANOVA with time and treatment as within subject factors. A Bonferroni post hoc test was used to locate differences between means for all statistically significant interactions. Phenylalanine: Time effect: $P<0.001$, Time $\times$ Treatment: $P<0.001$. Tyrosine: Time effect: $P<0.001$; Time $\times$ Treatment: $P<0.001$. Leucine: Time effect $P<0.001$, Time $\times$ Treatment $P<0.001$. Beef, minced beef. Milk, skim milk.

\section{PLASMA TRACERS AND WHOLE-BODY AMINO ACID KINETICS}

Basal plasma L-[ring ${ }^{2} \mathrm{H}_{5}$ ]-phenylalanine enrichments did not differ between treatments $(P=0.89$; Figure 4.3A). L-[ring- ${ }^{2} \mathrm{H}_{5}$ ]-phenylalanine enrichments decreased after milk and beef ingestion $(P<0.001)$, with a more rapid decline in $\mathrm{L}$-[ring $\left.{ }^{2}{ }^{2} \mathrm{H}_{5}\right]$-phenylalanine enrichments after beef ingestion (Time $\times$ Treatment interaction $P=0.001$ ). Plasma $\mathrm{L}-\left[1{ }^{13} \mathrm{C}\right]$-phenylalanine enrichments increased to a greater extent after the ingestion of beef when compared with milk (Time $\times$ Treatment interaction $P<0.001$; Figure 4.3B). 
A

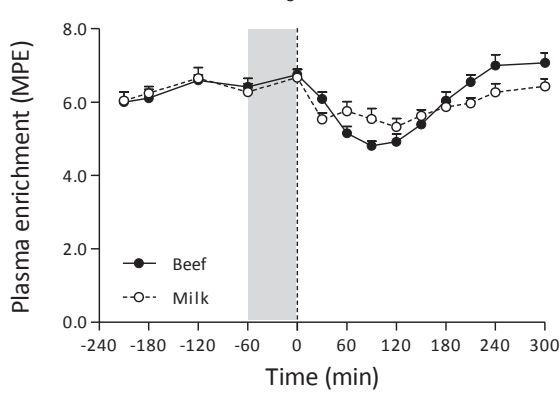

B

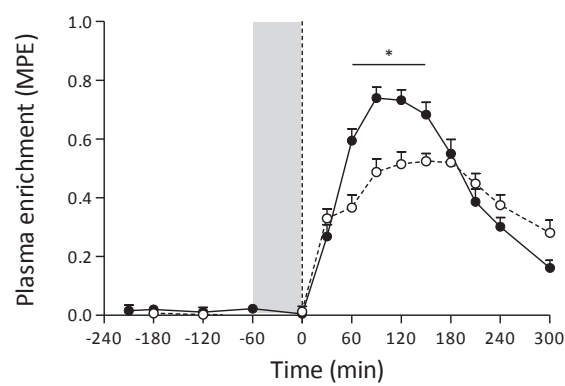

Figure 4.3 | Mean ( \pm SEM) plasma L-[ring $\left.-{ }^{2} \mathrm{H}_{5}\right]$-phenylalanine $(\mathrm{A})$ and $\mathrm{L}-\left[1-{ }^{13} \mathrm{C}\right]$-phenylalanine $(\mathrm{B})$ enrichments (mole percent excess, MPE) in the fasting state and after the ingestion of beef $(n=12)$ or milk $(n=12)$ during post-exercise recovery. Grey area corresponds to the exercise bout; dashed line refers to protein ingestion. * Treatment conditions differ at these time points. Data were analyzed with a two-factor repeated measures ANOVA with time and treatment as within subject factors. A Bonferroni post hoc test was used to locate differences between means for all statistically significant interactions. $\mathrm{L}-\left[\right.$ ring $\left.^{-2} \mathrm{H}_{5}\right]$-phenylalanine: Time $\times$ Treatment interaction $P=0.001 . \mathrm{L}-\left[1{ }^{13} \mathrm{C}\right]$-phenylalanine: Time $\times$ Treatment interaction $P<0.001$.

Exogenous phenylalanine rates of appearance (representing the appearance of dietary proteinderived phenylalanine into the circulation) increased after beef or milk ingestion $(P<0.001)$ Exogenous phenylalanine appearance rates were higher between 60 and $150 \mathrm{~min}$ after ingestion of beef when compared with milk ingestion (Time $\times$ Treatment interaction $P<0.001$; Figure 4.4A). The amount of dietary protein-derived phenylalanine that appeared in the circulation over the $5 \mathrm{~h}$ postprandial period tended to be higher after ingestion of beef when compared with milk $(64 \pm 3$ and $57 \pm 4 \%$, respectively; $P=0.08$ ). Endogenous phenylalanine rates of appearance (representing the appearance of phenylalanine derived from whole-body protein breakdown into the circulation) were lowered after beef or milk ingestion (Time effect $P<0.001$, Treatment effect $P=0.02$; Figure $4.4 \mathrm{~B}$ ). Total phenylalanine rates of appearance and total phenylalanine rates of disappearance increased to a greater extent after beef when compared with milk ingestion (Time $\times$ Treatment interaction $P<0.001$ and $P<0.001$, respectively; Figure $4.4 C$ and $D)$. Phenylalanine oxidation rates did not differ $(P=0.51)$ between the beef $\left(7.2 \pm 0.3 \mu \mathrm{mol} \cdot \mathrm{kg}^{-1} \cdot \mathrm{h}^{-1}\right)$ and milk treatments $(7.4 \pm 0.3$ $\left.\mu \mathrm{mol} \cdot \mathrm{kg}^{-1} \cdot \mathrm{h}^{-1}\right)$. 
A

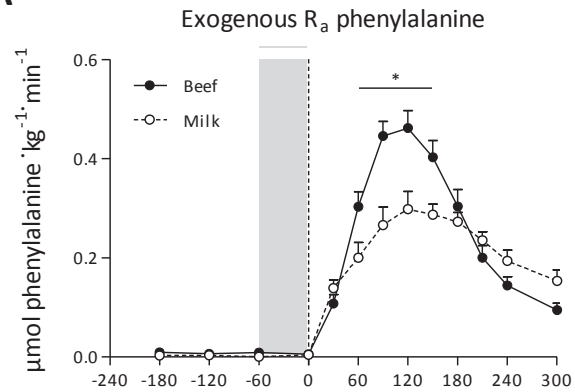

C

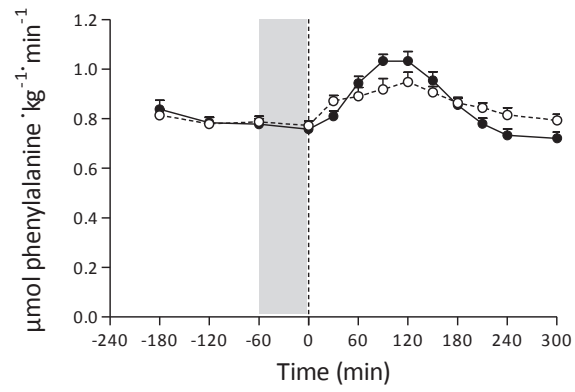

B

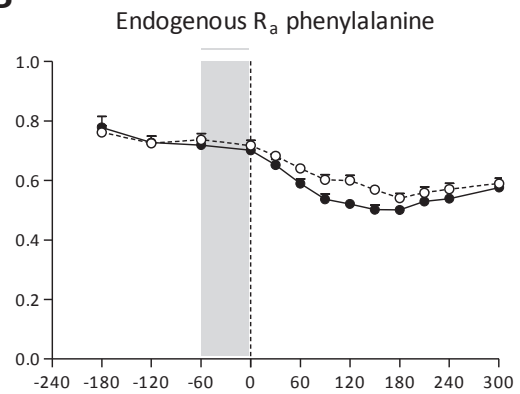

D

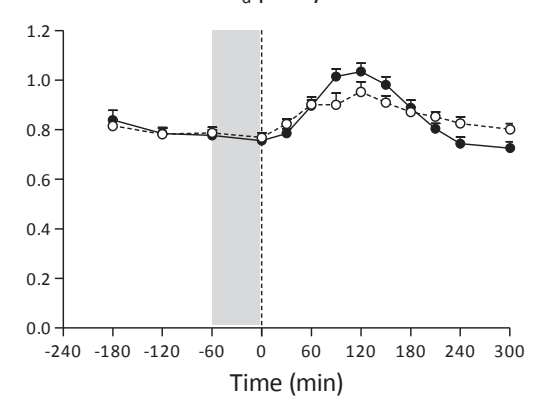

Figure 4.4 Whole-body phenylalanine kinetics. Mean ( \pm SEM) exogenous rate of appearance $\left(R_{a} ; A\right)$, endogenous $R_{a}(B)$, total $R_{a}(C)$, and total rate of disappearance $\left(R_{d} ; D\right)\left(\mu m o l\right.$ phenylalanine $\left.\cdot \mathrm{kg}^{-1} \cdot \mathrm{min}^{-1}\right)$ in the fasting state and after the ingestion of beef $(n=12)$ or milk $(n=12)$ during post-exercise recovery. Grey area corresponds to the exercise bout; dashed line refers to protein ingestion. * Treatment conditions differ at these time points. Data were analyzed with a two-factor repeated measures ANOVA with time and treatment as within subject factors. A Bonferroni post hoc test was used to locate differences between means for all statistically significant interactions. Exogenous $R_{a}$ : Time $\times$ Treatment interaction $P<0.001$. Endogenous $R_{a}$ : Time $\times$ Treatment interaction $P=0.12$, Time effect $P<0.001$, Treatment effect $P=0.02$. Total $R_{a}$ : Time $\times$ Treatment interaction $P=0.001$. Total $R_{d}$ : Time $\times$ Treatment interaction $P=0.001$.

\section{MUSCLE ANABOLIC SIGNALING}

Immediately after resistance exercise, mTORC1 phosphorylation did not differ from resting, baseline conditions. During post-exercise recovery, mTORC1 phosphorylation had increased at $2 \mathrm{~h}$ $(P=0.006)$ and returned to baseline values at $5 \mathrm{~h}(P=0.64)$ with no differences between the milk and beef conditions $(P>0.05$; Figure $4.5 \mathrm{~A})$. Phosphorylation of $4 \mathrm{E}-\mathrm{PB} 1$ was reduced immediately after cessation of exercise when compared to resting, baseline values $(P<0.001)$. Phosphorylation status of $4 \mathrm{E}-\mathrm{PB} 1$ returned to resting, baseline values during recovery from exercise, with no differences after milk vs beef ingestion (Figure 4.5B). The phosphorylation of p7056K1 increased immediately after exercise $(P<0.001)$ and remained elevated above baseline values throughout post-exercise recovery with no differences between beef and milk ingestion (Figure 4.5C). No changes were observed in rpS6 phosphorylation directly after exercise in the milk or beef condition $(P=0.17)$. The rpS6 phosphorylation status increased with highest values reached at $2 \mathrm{~h}(P<0.001)$ after which the values returned to baseline in both the milk and beef treatment (Figure 4.5D). 
A
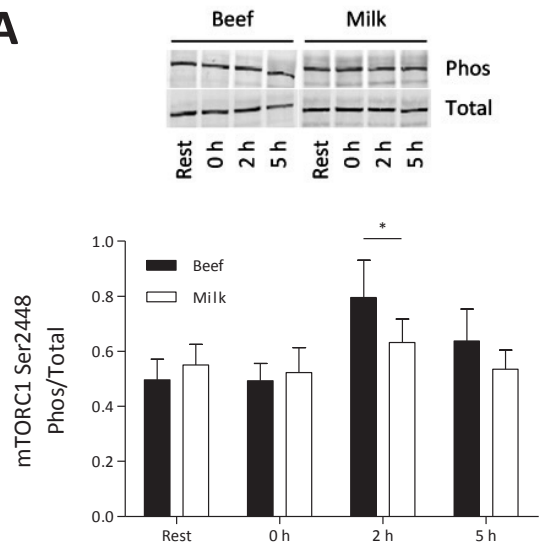

C
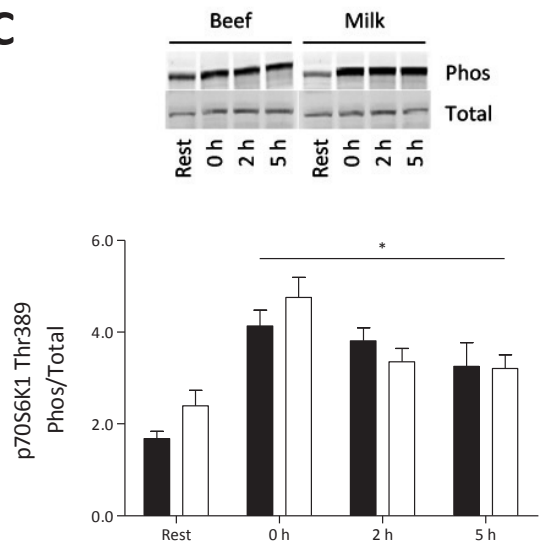

B
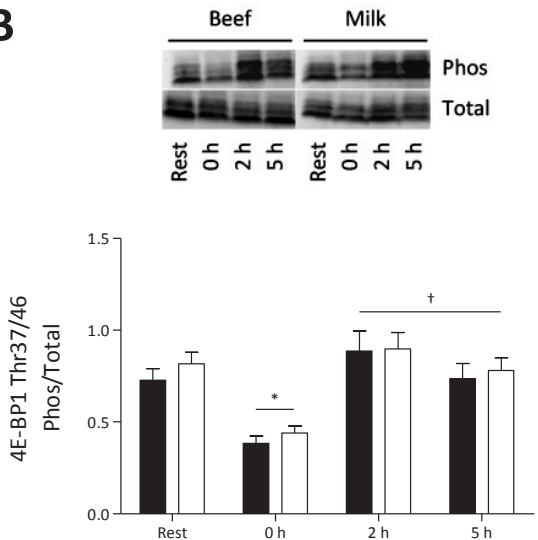

D
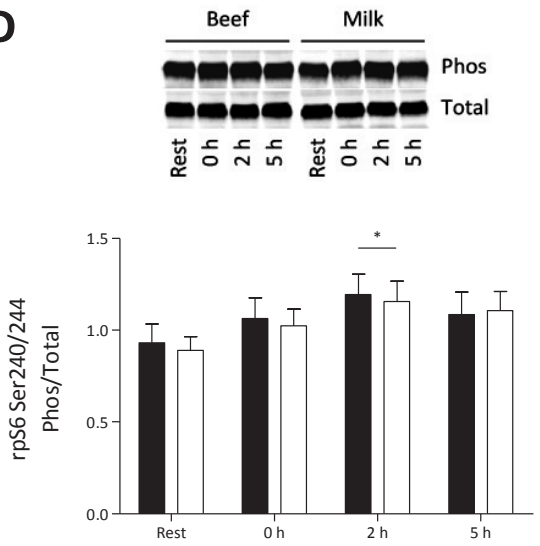

Figure 4.5 | Mean ( \pm SEM) phosphorylation status of mammalian target of rapamycin complex 1 (mTORC1) at Ser2448 (A), eukaryotic translation initiation factor 4E-binding protein 1 (4E-BP1) at Thr37/46 (B), $70 \mathrm{kDa}$ S6 protein kinase 1 (p70S6K1) at Thr389 (C), and ribosomal protein S6 (rpS6) at Ser235/236 (D) at rest and after the ingestion of beef $(n=12)$ or milk $(n=12)$ during post-exercise recovery. Data were analyzed with a two-factor repeated measures ANOVA with time and treatment as within subject factors. A Bonferroni post hoc test was used to locate differences between means for all statistically significant interactions. mTORC1: Time $\times$ Treatment interaction $P=0.16$, Time effect $P=0.006$. 4E-BP1: Time $\times$ Treatment interaction $P=0.90$, Time effect $P<0.001$. p70S6K1: Time $\times$ Treatment interaction $P=0.18$, Time effect $P<0.001$. rpS6: Time $\times$ Treatment interaction $P=0.9$, Time effect $P<0.001$. ${ }^{*}$ Significantly different when compared with rest. $\dagger$ Significantly different when compared to immediately after resistance exercise $(t=0 \mathrm{~h})$.

\section{MYOFIBRILLAR PROTEIN SYNTHESIS}

Myofibrillar protein synthesis rates increased after milk and beef ingestion during both the early $(0-2 \mathrm{~h})$ and late $(2-5 \mathrm{~h})$ postprandial phase $(128 \pm 23$ and $91 \pm 15 \%$ above baseline values; $P<0.001$; Figure 4.6). During the early postprandial phase (0-2 h), milk ingestion resulted in a greater myofibrillar protein synthetic response when compared with beef ingestion ( $P=0.013)$. However, the cumulative myofibrillar protein synthetic response calculated over the entire $5 \mathrm{~h}$ postprandial phase did not differ $(P=0.114 ; 95 \% \mathrm{Cl}:-0.033-0.004)$ between the ingestion of beef $\left(0.057 \pm 0.006 \% \cdot h^{-1}\right)$ when compared with milk $\left(0.071 \pm 0.005 \% \cdot h^{-1}\right)$. 


\section{Myofibrillar protein}

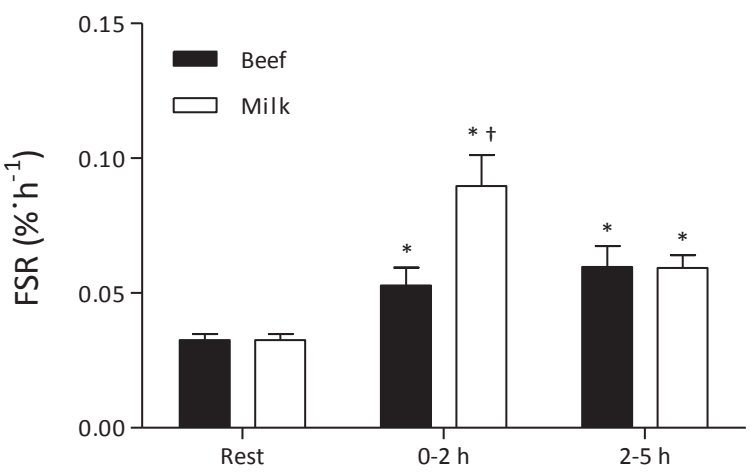

Figure 4.6 Mean ( \pm SEM) myofibrillar protein synthesis rates expressed as fractional synthesis rates (FSR) before (Rest) and after $30 \mathrm{~g}$ milk $(n=12)$ and beef $(n=12)$ ingestion during recovery from exercise. Data were analyzed with a twofactor repeated measures ANOVA with time and treatment as within subject factors. A Bonferroni post hoc test was used to locate differences between means for all statistically significant interactions. Time $\times$ Treatment interaction $P=0.006$, Time effect $P<0.001$, Treatment effect $P=0.055$. ${ }^{*}$ Significantly different when compare with Rest. $\dagger$ Significantly different between treatments. 


\section{Discussion}

The present study demonstrated that the ingestion of beef resulted in a more rapid release of protein-derived phenylalanine into the circulation and greater postprandial plasma amino acid availability throughout $5 \mathrm{~h}$ of post-exercise recovery when compared with the ingestion of an isonitrogenous amount of milk. Despite the more rapid postprandial rise in plasma amino acid availability after beef as opposed to milk ingestion, milk ingestion resulted in a greater myofibrillar protein synthetic response during the early stages of the postprandial period $(0-2 \mathrm{~h})$. The overall postprandial myofibrillar protein synthetic response assessed over $5 \mathrm{~h}$ of post-exercise recovery did not differ between milk or beef consumption.

Various studies have investigated the postprandial muscle protein synthetic response after the ingestion of isolated protein sources (such as soy, casein, or whey protein) to show that the rate of protein digestion and amino acid absorption and the subsequent rise in plasma amino acid availability (with leucine being of particular interest) form key factors that modulate the postprandial muscle protein synthetic response (1-4). In the present study, we assessed the impact of ingesting protein dense foods (milk and beef) on dietary protein digestion and absorption kinetics and the subsequent postprandial myofibrillar protein synthetic response. The protein meals contained different amounts of carbohydrate and fat and thus varied in energy content (Table 4.2). However, previous work has shown that the energy content of a meal modulates dietary protein digestion and absorption kinetics (6), but does not affect postprandial or postexercise muscle protein synthesis rates $(6,21,22)$.

Here, we observed a more rapid protein digestion and amino acid absorption after beef ingestion, which resulted in a greater rise in plasma amino acid availability $(64 \pm 3$ vs $57 \pm 3 \% ; P<0.05)$ and higher peak plasma leucine concentrations ( $277 \pm 12$ vs $231 \pm 11 \mu \mathrm{M} ; P<0.05$; Figure $4.2 \mathrm{C}$ ) in the beef when compared with the milk treatment, respectively. Although this would predict a greater postprandial myofibrillar protein synthetic response after beef versus milk ingestion, we did not observe any statistically significant differences in the overall $5 \mathrm{~h}$ myofibrillar protein synthetic response between treatments $\left(0.057 \pm 0.006\right.$ and $0.071 \pm 0.005 \% \cdot h^{-1}$, respectively; $P>0.05$; Figure 4.6$)$. Interestingly, we observed an even greater myofibrillar protein synthetic response after milk when compared with beef ingestion during the early $(0-2 \mathrm{~h})$ postprandial phase (Figure 4.6). This greater early myofibrillar protein synthetic response after milk compared with beef ingestion may be attributed to the small but rapid rise in circulating plasma leucine (Figure 4.2C) and/or insulin (Figure 4.1B) concentrations during the first $30 \mathrm{~min}$ after milk ingestion. This rapid rise in circulating plasma leucine concentrations after milk ingestion may have initiated an accelerated rise in postprandial myofibrillar protein synthesis rates and allowed for a greater myofibrillar protein synthetic response during the early stages of the post-exercise recovery in the milk compared with the beef treatment. It is generally assumed that the stimulation of postprandial muscle protein synthesis is attributed to the acute rise in plasma essential amino acid availability and is independent of the effects of increased insulinemia after food intake in healthy young or older adults (23). Hence, it is unlikely that the greater postprandial rise in circulating insulin after milk ingestion is responsible for the greater early postprandial myofibrillar protein synthetic response $(0-2 \mathrm{~h}$ ) when compared with the ingestion of beef. However, the cumulative postprandial myofibrillar protein synthetic response (0-5 h) after milk and beef ingestion did not show a statistically significant difference between treatments $(P=0.12)$, despite greater postprandial amino acid availability and higher peak leucine concentrations after beef ingestion. The cumulative muscle protein synthetic response likely provides more insight into the efficacy of protein intake after exercise to augment gains in muscle mass (24). The fact that the greater postprandial plasma 
leucine availability after beef compared with milk ingestion did not lead to a greater post-exercise muscle protein synthetic response may be, at least partly, explained by the increased sensitivity of skeletal muscle tissue to circulating leucine during recovery from exercise (25). In addition, the generous amount of protein provided via milk or beef ingestion (both $30 \mathrm{~g}$ protein) may have precluded our ability to detect differences in the entire $0-5 \mathrm{~h}$ post-exercise myofibrillar protein synthetic response between beef and milk ingestion.

Alternatively, it has also been speculated that milk has various other anabolic properties that may explain the absence of a difference in the postprandial muscle protein synthetic response between groups. For example, milk is a potent insulin secretagogue (26) (Figure 4.1B). However, it is unlikely that the greater postprandial rise in circulating insulin further increased postprandial muscle protein synthesis rates as the postprandial insulin response has been reported to be permissive rather than stimulatory under conditions of increased plasma amino acid availability $(22,23,27)$. Moreover, bioactive peptides in milk (28) or the endogenous release of miRNAs into circulation after milk ingestion $(29,30)$ may have served as an anabolic signal to peripheral tissues (muscle). It is worth noting that Wilkinson et al. (31) showed that milk consumption immediately after the cessation of resistance type exercise resulted in higher post-exercise muscle protein synthesis rates when compared with the ingestion of equivalent bolus of soy protein. In short, the greater myofibrillar protein synthetic response after milk as opposed to beef ingestion during the early postprandial phase may also be partly attributed to these and/or other nutritional factors present in protein dense foods.

The initiation of mRNA translation has been reported to be primarily responsible for the regulation of muscle protein synthesis (32). Translation initiation is largely controlled by the activation of mTORC1-related signaling molecules (33). Exercise and protein ingestion have been shown to activate mRNA translation initiation through the mTORC1 pathway (34-36). As such, it is often suggested that maximizing $\mathrm{mTORC} 1$ activation throughout post-exercise recovery is essential for facilitating the skeletal muscle adaptive response (37). Here, the examination of mTORC1, 4E-BP1, p70S6K1, or rpS6 phosphorylation provided little insight into the mechanisms that govern changes in myofibrillar protein accretion after milk or beef ingestion (Figure 4.5). We have previously shown that the ingestion of carbohydrate and protein during recovery from exercise further elevated the phosphorylation of $\mathrm{mTORC} 1$ signaling related proteins when compared to the ingestion of carbohydrates alone (34). In the current study, we did not observe any differences in the protein phosphorylation status throughout post-exercise recovery after milk versus beef ingestion. It might be possible that the mTORC1 pathway was being activated via different mechanisms between the milk and the beef condition. For example, the higher leucinemia after beef ingestion may have been a principle driver, whereas in the milk condition other factors (e.g., postprandial insulin response, miRNAs, or bioactive peptides) may have been responsible for activating mTORC1 signaling proteins. The reduced phosphorylation of 4E-BP1 immediately after exercise is consistent with previous observations (36), and likely represents a shift of energy provision to fuel muscle contraction rather than the synthesis of de novo myofibrillar protein (38). In conclusion, ingestion of $30 \mathrm{~g}$ protein, provided in beef or milk, during recovery from exercise strongly increases myofibrillar protein synthesis rates in young males. Beef ingestion during recovery from resistance type exercise is followed by more rapid protein digestion and amino acid absorption, resulting in greater postprandial plasma amino acid availability and higher peak plasma leucine concentrations when compared with the ingestion of an isonitrogenous amount of milk. However, milk ingestion during recovery from exercise is followed by a greater early (but not overall) postprandial myofibrillar protein synthetic response when compared with beef ingestion. 


\section{REFERENCES}

1. Koopman R, Crombach N, Gijsen AP, Walrand S, Fauquant J, Kies AK, Lemosquet S, Saris WH, Boirie Y, van Loon $\mathrm{LJ}$. Ingestion of a protein hydrolysate is accompanied by an accelerated in vivo digestion and absorption rate when compared with its intact protein. Am J Clin Nutr 2009;90(1):106-15.

2. Pennings B, Boirie $Y$, Senden JM, Gijsen AP, Kuipers $H$, van Loon LJ. Whey protein stimulates postprandial muscle protein accretion more effectively than do casein and casein hydrolysate in older men. Am J Clin Nutr 2011;93(5):997-1005.

3. Tang JE, Moore DR, Kujbida GW, Tarnopolsky MA, Phillips SM. Ingestion of whey hydrolysate, casein, or soy protein isolate: effects on mixed muscle protein synthesis at rest and following resistance exercise in young men. Journal of applied physiology 2009;107(3):987-92.

4. Burd NA, Yang Y, Moore DR, Tang JE, Tarnopolsky MA, Phillips SM. Greater stimulation of myofibrillar protein synthesis with ingestion of whey protein isolate v. micellar casein at rest and after resistance exercise in elderly men. The British journal of nutrition 2012;108(6):958-62.

5. Yang Y, Breen L, Burd NA, Hector AJ, Churchward-Venne TA, Josse AR, Tarnopolsky MA, Phillips SM. Resistance exercise enhances myofibrillar protein synthesis with graded intakes of whey protein in older men. The British journal of nutrition 2012;108(10):1780-8.

6. Gorissen SH, Burd NA, Hamer HM, Gijsen AP, Groen BB, van Loon LJ. Carbohydrate co-ingestion delays dietary protein digestion and absorption but does not modulate postprandial muscle protein accretion. J Clin Endocrinol Metab 2014:jc20133970.

7. Pimentel D, Pimentel M. Sustainability of meat-based and plant-based diets and the environment. The American journal of clinical nutrition 2003;78(3 Suppl):660S-3S.

8. Tieland M, Borgonjen-Van den Berg KJ, van Loon LJ, de Groot LC. Dietary protein intake in community-dwelling, frail, and institutionalized elderly people: scope for improvement. European journal of nutrition 2012;51(2):1739.

9. Burd NA, Groen BB, Beelen M, Senden JM, Gijsen AP, van Loon LJ. The reliability of using the single-biopsy approach to assess basal muscle protein synthesis rates in vivo in humans. Metabolism: clinical and experimental 2012;61(7):931-6.

10. Burd NA, Pennings B, Groen BB, Gijsen AP, Senden JM, van Loon LJ. The single biopsy approach is reliable for the measurement of muscle protein synthesis rates in vivo in older men. Journal of applied physiology 2012;113(6):896-902.

11. Burd NA, West DW, Rerecich T, Prior T, Baker SK, Phillips SM. Validation of a single biopsy approach and bolus protein feeding to determine myofibrillar protein synthesis in stable isotope tracer studies in humans. Nutrition \& metabolism 2011;8:15.

12. Burd NA, Hamer HM, Pennings B, Pellikaan WF, Senden JMG, Gijsen AP, van Loon LJC. Substantial Differences between Organ and Muscle Specific Tracer Incorporation Rates in a Lactating Dairy Cow. PloS one 2013;8(6):e68109.

13. Wall BT, Dirks ML, Snijders T, Senden JM, Dolmans J, van Loon LJ. Substantial skeletal muscle loss occurs during only 5 days of disuse. Acta physiologica (Oxford, England) 2014;210(3):600-11.

14. Burd NA, Cermak NM, Kouw IW, Gorissen SH, Gijsen AP, van Loon LJ. The use of doubly labeled milk protein to measure postprandial muscle protein synthesis rates in vivo in humans. Journal of applied physiology (Bethesda, Md : 1985) 2014;117(11):1363-70.

15. Calder AG, Anderson SE, Grant I, McNurlan MA, Garlick PJ. The determination of low d5-phenylalanine enrichment (0.002-0.09 atom percent excess), after conversion to phenylethylamine, in relation to protein turnover studies by gas chromatography/electron ionization mass spectrometry. Rapid Commun Mass Spectrom 1992;6(7):421-4.

16. Slater C, Preston T, McMillan DC, Falconer JS, Fearon $\mathrm{KCH}$. GC/MS analysis of [2H5]phenylalanine at very low enrichment: Measurement of protein synthesis in health and disease. Journal of Mass Spectrometry 1995;30(9):1325-32.

17. Schwenk WF, Berg PJ, Beaufrere B, Miles JM, Haymond MW. Use of t-butyldimethylsilylation in the gas chromatographic/mass spectrometric analysis of physiologic compounds found in plasma using electronimpact ionization. Analytical biochemistry 1984;141(1):101-9.

18. Patterson BW, Zhao G, Klein S. Improved accuracy and precision of gas chromatography/mass spectrometry measurements for metabolic tracers. Metabolism: clinical and experimental 1998;47(6):706-12.

19. Dangin M, Guillet C, Garcia-Rodenas C, Gachon P, Bouteloup-Demange C, Reiffers-Magnani K, Fauquant J, Ballevre $\mathrm{O}$, Beaufrere $\mathrm{B}$. The rate of protein digestion affects protein gain differently during aging in humans. J Physiol 2003;549(Pt 2):635-44.

20. Pennings B, Groen BB, van Dijk JW, de Lange A, Kiskini A, Kuklinski M, Senden JM, van Loon LJ. Minced beef is more rapidly digested and absorbed than beef steak, resulting in greater postprandial protein retention in older men. Am J Clin Nutr 2013;98(1):121-8.

21. Glynn EL, Fry CS, Timmerman KL, Drummond MJ, Volpi E, Rasmussen BB. Addition of Carbohydrate or Alanine to an Essential Amino Acid Mixture Does Not Enhance Human Skeletal Muscle Protein Anabolism. J Nutr 2013.

22. Staples AW, Burd NA, West DW, Currie KD, Atherton PJ, Moore DR, Rennie MJ, Macdonald MJ, Baker SK, Phillips SM. Carbohydrate does not augment exercise-induced protein accretion versus protein alone. Med Sci Sports Exerc 2011;43(7):1154-61. 
23. Greenhaff PL, Karagounis LG, Peirce N, Simpson EJ, Hazell M, Layfield R, Wackerhage H, Smith K, Atherton P, Selby A, et al. Disassociation between the effects of amino acids and insulin on signaling, ubiquitin ligases, and protein turnover in human muscle. Am J Physiol Endocrinol Metab 2008;295(3):E595-604.

24. Cermak NM, Res PT, de Groot LC, Saris WH, van Loon LJ. Protein supplementation augments the adaptive response of skeletal muscle to resistance-type exercise training: a meta-analysis. Am J Clin Nutr 2012;96(6):1454-64.

25. Burd NA, West DW, Moore DR, Atherton PJ, Staples AW, Prior T, Tang JE, Rennie MJ, Baker SK, Phillips SM. Enhanced amino acid sensitivity of myofibrillar protein synthesis persists for up to $24 \mathrm{~h}$ after resistance exercise in young men. The Journal of nutrition 2011;141(4):568-73.

26. Nilsson M, Stenberg M, Frid AH, Holst JJ, Bjorck IM. Glycemia and insulinemia in healthy subjects after lactoseequivalent meals of milk and other food proteins: the role of plasma amino acids and incretins. The American journal of clinical nutrition 2004;80(5):1246-53.

27. Cuthbertson D, Smith K, Babraj J, Leese G, Waddell T, Atherton P, Wackerhage H, Taylor PM, Rennie MJ. Anabolic signaling deficits underlie amino acid resistance of wasting, aging muscle. Faseb J 2005;19(3):422-4.

28. Nagpal R, Behare P, Rana R, Kumar A, Kumar M, Arora S, Morotta F, Jain S, Yadav H. Bioactive peptides derived from milk proteins and their health beneficial potentials: an update. Food \& function 2011;2(1):18-27.

29. Baier SR, Nguyen C, Xie F, Wood JR, Zempleni J. MicroRNAs are absorbed in biologically meaningful amounts from nutritionally relevant doses of cow milk and affect gene expression in peripheral blood mononuclear cells, HEK-293 kidney cell cultures, and mouse livers. The Journal of nutrition 2014;144(10):1495-500.

30. Laubier J, Castille J, Guillou SL, Provost FL. No effect of an elevated miR-30b level in mouse milk on its level in pup tissues. RNA biology 2015;12(1):26-9.

31. Wilkinson SB, Tarnopolsky MA, Macdonald MJ, Macdonald JR, Armstrong D, Phillips SM. Consumption of fluid skim milk promotes greater muscle protein accretion after resistance exercise than does consumption of an isonitrogenous and isoenergetic soy-protein beverage. The American journal of clinical nutrition 2007;85(4):1031-40.

32. Kimball SR, Farrell PA, Jefferson LS. Invited Review: Role of insulin in translational control of protein synthesis in skeletal muscle by amino acids or exercise. Journal of applied physiology 2002;93(3):1168-80.

33. Proud CG. mTORC1 signalling and mRNA translation. Biochemical Society transactions 2009;37(Pt 1):227-31.

34. Koopman R, Pennings B, Zorenc AH, van Loon LJ. Protein ingestion further augments S6K1 phosphorylation in skeletal muscle following resistance type exercise in males. J Nutr 2007;137(8):1880-6.

35. Moore DR, Atherton PJ, Rennie MJ, Tarnopolsky MA, Phillips SM. Resistance exercise enhances mTOR and MAPK signalling in human muscle over that seen at rest after bolus protein ingestion. Acta physiologica (Oxford, England) 2011;201(3):365-72.

36. Dreyer HC, Fujita S, Cadenas JG, Chinkes DL, Volpi E, Rasmussen BB. Resistance exercise increases AMPK activity and reduces $4 \mathrm{E}-\mathrm{BP} 1$ phosphorylation and protein synthesis in human skeletal muscle. The Journal of physiology 2006;576(Pt 2):613-24.

37. Terzis G, Georgiadis G, Stratakos G, Vogiatzis I, Kavouras S, Manta P, Mascher H, Blomstrand E. Resistance exercise-induced increase in muscle mass correlates with p70S6 kinase phosphorylation in human subjects. European journal of applied physiology 2008;102(2):145-52.

38. Rose AJ, Alsted TJ, Jensen TE, Kobbero JB, Maarbjerg SJ, Jensen J, Richter EA. A Ca(2+)-calmodulin-eEF2K-eEF2 signalling cascade, but not AMPK, contributes to the suppression of skeletal muscle protein synthesis during contractions. The Journal of physiology 2009;587(Pt 7):1547-63. 
RESTSTANGE FARCISE

The anabolic properties of wheat protein (hydrolysate) compared to casein and whey protein: a randomized trial

Stefan H.M. Gorissen Astrid M.H. Horstman Rinske Franssen Julie J.R. Crombag Henning Langer Jörgen Bierau Frederique Respondek Luc J.C. van Loon

Submitted
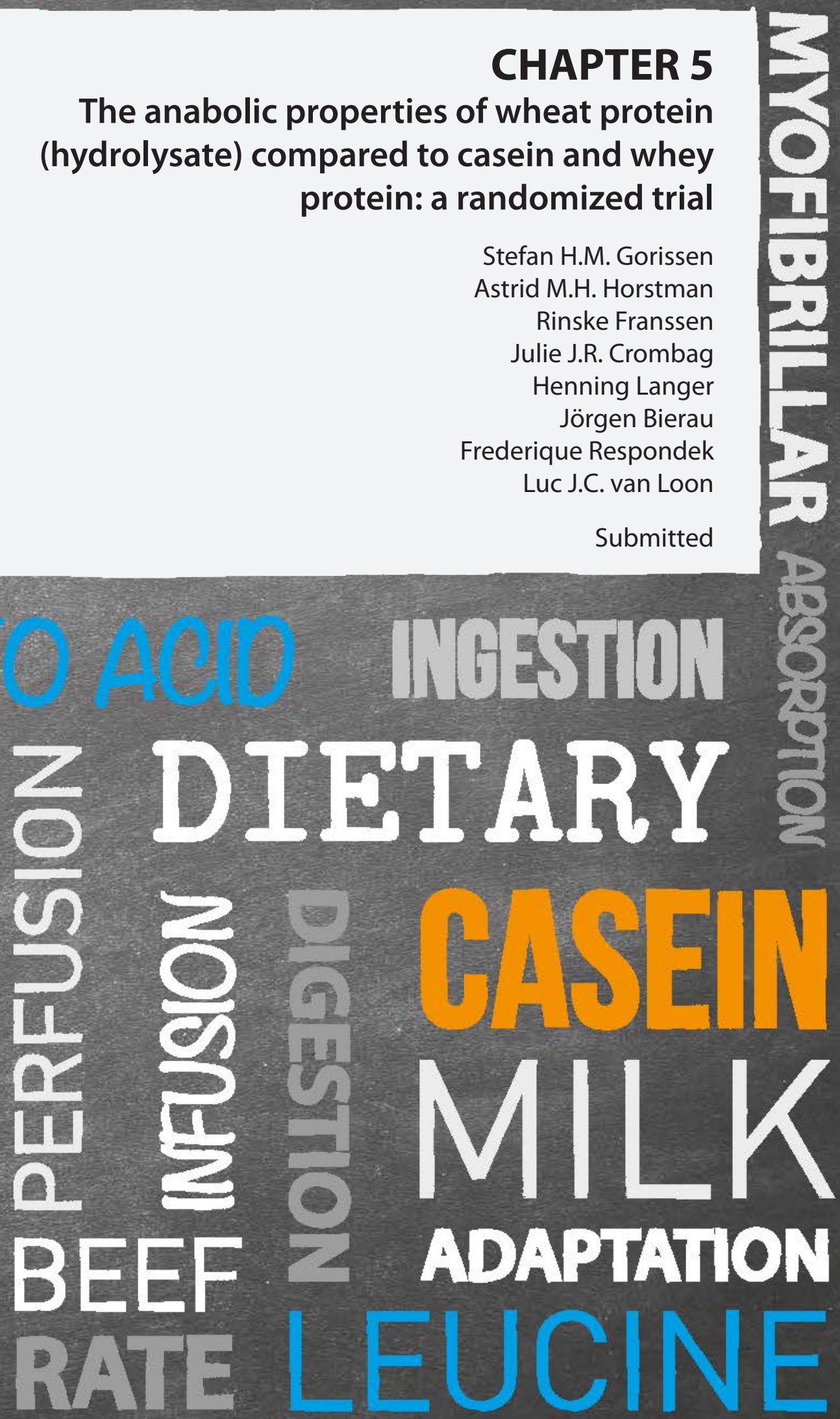


\section{ABSTRACT}

BACKGROUND: Muscle mass maintenance is largely regulated by basal muscle protein synthesis rates and the capacity to stimulate muscle protein synthesis rates following food intake. The postprandial muscle protein synthetic response is modulated by the amount, source, and type of protein consumed. It has been suggested that plant-based proteins are less potent in stimulating postprandial muscle protein synthesis rates when compared with animal-derived proteins. However, few data support this contention.

OBJECTIVE: To assess postprandial plasma amino acid profiles and the muscle protein synthetic response to the ingestion of wheat protein (hydrolysate) compared to casein and whey protein.

DESIGN: Sixty healthy older males (age: $71 \pm 1 \mathrm{y}, \mathrm{BMI}: 25.3 \pm 0.3 \mathrm{~kg} \cdot \mathrm{m}^{-2}$ ) received a primed continuous infusion of L-[ring- ${ }^{13} \mathrm{C}_{6}$ ]-phenylalanine and L-[ring-3,5- ${ }^{2} \mathrm{H}_{2}$ ]-tyrosine and ingested $35 \mathrm{~g}$ wheat protein ( $n=12), 35 \mathrm{~g}$ wheat protein hydrolysate $(n=12), 35 \mathrm{~g}$ micellar casein $(n=12), 35 \mathrm{~g}$ whey protein $(n=12)$, or $60 \mathrm{~g}$ wheat protein hydrolysate $(n=12)$. Plasma and muscle samples were collected at regular intervals throughout the infusion.

RESULTS: The postprandial rise in plasma essential amino acid concentrations was greater after the ingestion of $35 \mathrm{~g}$ whey protein compared to casein and wheat protein $(P<0.01)$. Myofibrillar protein synthesis rates increased after the ingestion of $35 \mathrm{~g}$ casein $(P<0.01)$, and postprandial myofibrillar protein synthesis rates were higher after the ingestion of casein compared to wheat protein $(P=0.03)$. Despite similar leucine content, the postprandial rise in plasma leucine concentrations was greater after the ingestion of $35 \mathrm{~g}$ whey protein compared to $60 \mathrm{~g}$ wheat protein hydrolysate $(\mathrm{P}<0.01)$. Nevertheless, ingesting $60 \mathrm{~g}$ wheat protein hydrolysate increased myofibrillar protein synthesis rates above basal rates $(\mathrm{P}=0.02)$.

CONCLUSION: The myofibrillar protein synthetic response to the ingestion of $35 \mathrm{~g}$ casein is greater when compared with an equal amount of wheat protein. Ingesting a larger amount of wheat protein substantially increases myofibrillar protein synthesis rates in healthy older males. 


\section{INTRODUCTION}

Preservation of skeletal muscle mass throughout life is of key importance to maintain functional capacity and metabolic health $(1,2)$. Muscle mass maintenance is largely regulated by basal muscle protein synthesis rates and the ability to stimulate muscle protein synthesis rates following food intake (3). In particular, protein ingestion directly stimulates postprandial muscle protein synthesis rates (4-10). The muscle protein synthetic response to protein ingestion can be modulated by changing the amount, source, and type of protein consumed (11). Current research aims at identifying the characteristics of the ingested protein source that determine the magnitude of the postprandial muscle protein synthetic response to develop more effective dietary strategies that support muscle mass maintenance in health and disease.

Nearly $60 \%$ of our daily protein consumed is derived from plant-based protein sources (12). Despite the large contribution of plant-based proteins to our diet, relatively few studies have assessed the muscle protein synthetic response to the ingestion of plant-based proteins $(9,10,13-16)$. Nevertheless, it is generally believed that plant-based proteins are less anabolic when compared with animal-derived proteins due to lower digestibility and deficiencies in certain essential amino acids such as leucine, lysine, and/or methionine (17). Innovations in food processing have solved many issues regarding plant-based protein digestibility by the production of plant-based protein concentrates, isolates, and hydrolysates (18). Moreover, deficiencies in leucine, lysine, and/or methionine may exist in some but certainly not all plant-based proteins, as there is a great variety in the amino acid composition of plant-based proteins (17). Most human studies performed so far have compared the muscle protein synthetic response to the ingestion of soy protein with either casein (9), whey protein $(9,10)$, milk (16), or beef (15). Few data exist on the muscle protein synthetic response following the ingestion of other plant-based proteins.

Wheat protein is the most abundant plant-based protein in our diet, comprising $\sim 20 \%$ of total protein intake (12). Despite the low digestibility of whole wheat ( $45 \%)$, removal of anti-nutritional factors (i.e., compounds that interfere with protein digestion and absorption) has resulted in purified wheat protein with a digestibility similar to animal-derived proteins (>90\%) (18). The production of wheat protein hydrolysate has resulted in a more practical protein source to be used in various food products. However, wheat protein has a relatively low lysine and leucine content when compared with isonitrogenous amounts of animal-derived proteins (19). Therefore, it could be hypothesized that the muscle protein synthetic response to the ingestion of a single bolus of wheat protein (hydrolysate) is lower when compared with the ingestion of dairy protein. Consuming a greater amount of wheat protein (hydrolysate) should theoretically compensate for a relative lack of certain essential amino acids and allow for a greater postprandial muscle protein synthetic response.

In the present study we first compared postprandial plasma amino acid profiles and the subsequent muscle protein synthetic response following the ingestion of intact versus hydrolyzed wheat protein. Next, we compared the impact of ingesting $35 \mathrm{~g}$ wheat protein hydrolysate versus the ingestion of casein and whey protein on the postprandial muscle protein synthetic response in older males. Finally, we tested the hypothesis that the muscle protein synthetic response to the ingestion of $60 \mathrm{~g}$ wheat protein hydrolysate is similar to the ingestion of $35 \mathrm{~g}$ whey protein, containing similar amounts of leucine. By using intravenous infusions of $\mathrm{L}-\left[\mathrm{ring}^{-13} \mathrm{C}_{6}\right]$-phenylalanine and L-[ring-3,5- ${ }^{2} \mathrm{H}_{2}$-tyrosine, we are able to evaluate whole-body amino acid kinetics as well as basal and postprandial muscle protein synthesis rates following the ingestion of plant-based and dairy proteins in vivo in humans (20). This is the first study to provide a detailed evaluation on the anabolic properties of one of the main plant-based proteins in our diet. 


\section{Methods}

\section{PARTICIPANTS}

Sixty healthy older males (age: $71 \pm 1 \mathrm{y}, \mathrm{BMI}: 25.3 \pm 0.3 \mathrm{~kg} \cdot \mathrm{m}^{-2}$ ) participated in this double blind, parallel group randomized trial. The trial was conducted between January 2014 and October 2014 at Maastricht University in Maastricht, the Netherlands. Participants' characteristics are presented in Table 5.1. All participants were informed about the purpose of the study, experimental procedures, and possible risks prior to providing written consent to participate. The procedures followed were in accordance with the ethical standards of the medical ethics committee of Maastricht University Medical Center+ on human experimentation and in accordance with the Helsinki Declaration of 1975 as revised in October 2013.

Table 5.1 | Subjects' characteristics

\begin{tabular}{|c|c|c|c|c|c|}
\hline & $\begin{array}{c}35 \text { g wheat } \\
\text { protein }\end{array}$ & $\begin{array}{c}35 \text { g wheat } \\
\text { protein } \\
\text { hydrolysate }\end{array}$ & $35 \mathrm{~g}$ casein & 35 g whey & $\begin{array}{c}60 \mathrm{~g} \text { wheat } \\
\text { protein } \\
\text { hydrolysate }\end{array}$ \\
\hline & $n=12$ & $n=12$ & $n=12$ & $n=12$ & $n=12$ \\
\hline Age (y) & $68 \pm 1$ & $72 \pm 2 *$ & $73 \pm 1$ & $72 \pm 2$ & $68 \pm 1$ \\
\hline Weight (kg) & $77.1 \pm 1.7$ & $78.6 \pm 3.9$ & $75.1 \pm 2.8$ & $79.3 \pm 2.4$ & $81.0 \pm 3.0$ \\
\hline BMI $\left(\mathrm{kg} \cdot \mathrm{m}^{-2}\right)$ & $25.1 \pm 0.6$ & $25.5 \pm 1.0$ & $24.6 \pm 0.5$ & $25.2 \pm 0.5$ & $26.3 \pm 0.8$ \\
\hline Systolic BP (mmHg) & $138 \pm 6$ & $140 \pm 4$ & $139 \pm 5$ & $133 \pm 3$ & $139 \pm 6$ \\
\hline Diastolic BP (mmHg) & $77 \pm 3$ & $67 \pm 2 *$ & $69 \pm 3$ & $69 \pm 2$ & $71 \pm 3$ \\
\hline Fat (\%) & $22.9 \pm 1.1$ & $24.0 \pm 1.0$ & $25.1 \pm 1.2$ & $23.9 \pm 0.7$ & $25.4 \pm 1.1$ \\
\hline Appendicular lean mass $(\mathrm{kg})$ & $25.1 \pm 0.7$ & $24.5 \pm 1.0$ & $23.0 \pm 1.0$ & $25.1 \pm 0.7$ & $25.5 \pm 1.0$ \\
\hline Lean body mass (kg) & $57.4 \pm 1.5$ & $56.9 \pm 2.5$ & $53.6 \pm 2.0$ & $57.8 \pm 1.5$ & $58.1 \pm 2.2$ \\
\hline Fasting glucose $\left(\mathrm{mmol} \cdot \mathrm{L}^{-1}\right)$ & $6.0 \pm 0.1$ & $6.0 \pm 0.2$ & $6.0 \pm 0.2$ & $6.1 \pm 0.1$ & $5.8 \pm 0.1$ \\
\hline $2 \mathrm{~h}$ glucose $\left(\mathrm{mmol} \cdot \mathrm{L}^{-1}\right)$ & $6.5 \pm 0.3$ & $6.2 \pm 0.5$ & $6.1 \pm 0.5$ & $6.1 \pm 0.4$ & $5.5 \pm 0.5$ \\
\hline $\mathrm{HbA}_{1 \mathrm{c}}(\%)$ & $5.5 \pm 0.1$ & $5.6 \pm 0.1$ & $5.5 \pm 0.1$ & $5.3 \pm 0.1$ & $5.4 \pm 0.1$ \\
\hline OGIS $\left(\mathrm{mL} \cdot \mathrm{min}^{-1} \cdot \mathrm{m}^{-2}\right)$ & $351 \pm 11$ & $357 \pm 8$ & $351 \pm 23$ & $353 \pm 12$ & $357 \pm 18$ \\
\hline
\end{tabular}

Abbreviations: $\mathrm{BP}$, blood pressure; $\mathrm{HbA}_{1 c}$, glycated hemoglobin; OGIS, oral glucose insulin sensitivity. Statistical analysis was performed on the following comparisons: 1) $35 \mathrm{~g}$ wheat protein vs $35 \mathrm{~g}$ wheat protein hydrolysate, 2) $35 \mathrm{~g}$ wheat protein hydrolysate vs $35 \mathrm{~g}$ casein vs $35 \mathrm{~g}$ whey, and 3) $35 \mathrm{~g}$ whey vs $60 \mathrm{~g}$ wheat protein hydrolysate. * Significantly different from $35 \mathrm{~g}$ wheat protein $(\mathrm{P}<0.05)$.

\section{PRETESTING}

Volunteers between the age of 65 and $80 \mathrm{y}$ and a BMI between 18.5 and $30.0 \mathrm{~kg} \cdot \mathrm{m}^{-2}$ underwent a medical screening to assess their $\mathrm{HbA}_{1 \mathrm{c}}$ glucose tolerance (by a $2 \mathrm{~h}$ oral glucose tolerance test (21)), blood pressure, weight, height, and body composition (by Dual-energy X-ray absorptiometry; Discovery A; Hologic, Bedford, MA, USA). The participants were deemed healthy based on their responses to a medical questionnaire and screening results. Please see Online Supplemental Material for CONSORT flow diagram. 


\section{STUDY DESIGN}

Participants were randomly assigned to consume $35 \mathrm{~g}$ wheat protein (Amygluten, Tereos; $n=12$ ), 35 $\mathrm{g}$ wheat protein hydrolysate (Meripro, Tereos; $n=12$ ), $35 \mathrm{~g}$ micellar casein (Refit $\mathrm{MCl}$ 80, Domo; $n=12$ ), $35 \mathrm{~g}$ whey protein (Nutri Whey $800 \mathrm{~F}, \mathrm{DMV} ; n=12$ ), or $60 \mathrm{~g}$ wheat protein hydrolysate (Meripro, Tereos; $n=12$ ). Randomization was performed using a computerized random number generator. Within this study we compared the anabolic properties of A) $35 \mathrm{~g}$ intact wheat protein vs $35 \mathrm{~g}$ wheat protein hydrolysate, B) $35 \mathrm{~g}$ wheat protein hydrolysate vs $35 \mathrm{~g}$ casein vs $35 \mathrm{~g}$ whey protein, and C) $35 \mathrm{~g}$ whey protein vs $60 \mathrm{~g}$ wheat protein hydrolysate.

\section{DIET AND PHYSICAL ACTIVITY CONTROL}

All participants were instructed to refrain from any sort of strenuous physical activity and to keep their diet as consistent as possible for $2 \mathrm{~d}$ prior to the infusion trial. On the evening before the infusion trial, all participants consumed a standardized meal $(30.9 \pm 0.5 \mathrm{~kJ} / \mathrm{kg}$ body weight) composed of 16 energy percent (En\%) protein, $33 \mathrm{En \%}$ carbohydrate, and $51 \mathrm{En} \%$ fat.

\section{INFUSION PROTOCOL}

At 08:00 AM, following an overnight fast, participants arrived at the laboratory by car or public transport. A catheter was inserted into an antecubital vein for stable isotope amino acid infusion. A second catheter was inserted into a dorsal hand vein of the contralateral arm and placed in a hotbox $\left(60^{\circ} \mathrm{C}\right)$ for arterialized blood sampling (22). After taking a baseline blood sample, the plasma phenylalanine and tyrosine pools were primed with a single dose of $\mathrm{L}$-[ring $\left.{ }^{-13} \mathrm{C}_{6}\right]$-phenylalanine $(2.1$ $\left.\mu \mathrm{mol} \cdot \mathrm{kg}^{-1}\right)$ and L-[ring-3,5- ${ }^{2} \mathrm{H}_{2}$-tyrosine $\left(0.8 \mu \mathrm{mol} \cdot \mathrm{kg}^{-1}\right)$, after which a continuous L-[ring ${ }^{13} \mathrm{C}_{6}$ ]phenylalanine $\left(0.048 \mu \mathrm{mol} \cdot \mathrm{kg}^{-1} \cdot \mathrm{min}^{-1}\right)$ and $\mathrm{L}$-[ring-3,5- $\left.{ }^{2} \mathrm{H}_{2}\right]$-tyrosine $\left(0.018 \mu \mathrm{mol} \cdot \mathrm{kg}^{-1} \cdot \mathrm{min}^{-1}\right)$ intravenous infusion was initiated ( $\mathrm{t}=-270 \mathrm{~min}$ ). After resting in a supine position for $90 \mathrm{~min}, \mathrm{a}$ second arterialized blood sample was drawn and a muscle biopsy was collected from the vastus lateralis of a randomized leg $(\mathrm{t}=-180 \mathrm{~min})$. To determine basal muscle protein synthesis rates, a second muscle biopsy from the same leg was collected $180 \mathrm{~min}$ after the first biopsy. Subsequently, participants received a drink containing $35 \mathrm{~g}$ wheat protein $(n=12), 35 \mathrm{~g}$ wheat protein hydrolysate $(n=12), 35 \mathrm{~g}$ casein $(n=12), 35 \mathrm{~g}$ whey protein $(n=12)$, or $60 \mathrm{~g}$ wheat protein hydrolysate $(n=12)$ ( $t=0$ min; please see Table 5.2 for amino acid composition of the proteins). Arterialized blood samples were collected at $\mathrm{t}=-120,-90,-60,-30,0,15,30,45,60,75,90,120,150$, 180,210 , and $240 \mathrm{~min}$. Third and fourth muscle biopsies were collected from the contralateral leg at $\mathrm{t}=120$ and $\mathrm{t}=240 \mathrm{~min}$ to determine postprandial muscle protein synthesis rates. Blood samples were collected in EDTA containing tubes and centrifuged at $1000 \mathrm{~g}$ for $10 \mathrm{~min}$ at $4^{\circ} \mathrm{C}$. Aliquots of plasma were frozen in liquid nitrogen and stored at $-80^{\circ} \mathrm{C}$. Biopsies were collected from the middle region of the vastus lateralis, approximately $15 \mathrm{~cm}$ above the patella and $3 \mathrm{~cm}$ below entry through the fascia, using the percutaneous needle biopsy technique (23). Muscle samples were dissected carefully, freed from any visible non-muscle material, immediately frozen in liquid nitrogen, and stored at $-80^{\circ} \mathrm{C}$ until further analysis. For a schematic representation of the infusion protocol please see Figure 5.1. 
Table 5.2 | Amino acid composition of the 5 protein sources

\begin{tabular}{|c|c|c|c|c|c|}
\hline & $35 \mathrm{~g}$ wheat protein & $\begin{array}{l}35 \text { g wheat protein } \\
\text { hydrolysate }\end{array}$ & $35 \mathrm{~g}$ casein & 35 g whey & $\begin{array}{l}60 \text { g wheat protein } \\
\text { hydrolysate }\end{array}$ \\
\hline Histidine & 0.71 & 0.73 & 0.96 & 0.78 & 1.26 \\
\hline Isoleucine & 1.42 & 1.45 & 1.89 & 2.15 & 2.50 \\
\hline Leucine & 2.50 & 2.54 & 3.21 & 4.38 & 4.38 \\
\hline Lysine & 0.56 & 0.54 & 2.65 & 3.52 & 0.94 \\
\hline Methionine & 0.32 & 0.22 & 0.73 & 0.69 & 0.37 \\
\hline Phenylalanine & 1.90 & 1.93 & 1.70 & 1.34 & 3.33 \\
\hline Threonine & 0.91 & 0.92 & 1.38 & 1.74 & 1.58 \\
\hline Valine & 1.51 & 1.55 & 2.35 & 2.03 & 2.67 \\
\hline Total BCAA & 5.42 & 5.55 & 7.45 & 8.56 & 9.55 \\
\hline Total EAA & 9.83 & 9.89 & 14.86 & 16.63 & 17.03 \\
\hline
\end{tabular}

Abbreviations: BCAA, branched-chain amino acids; EAA, essential amino acids. Note: tryptophan not measured.
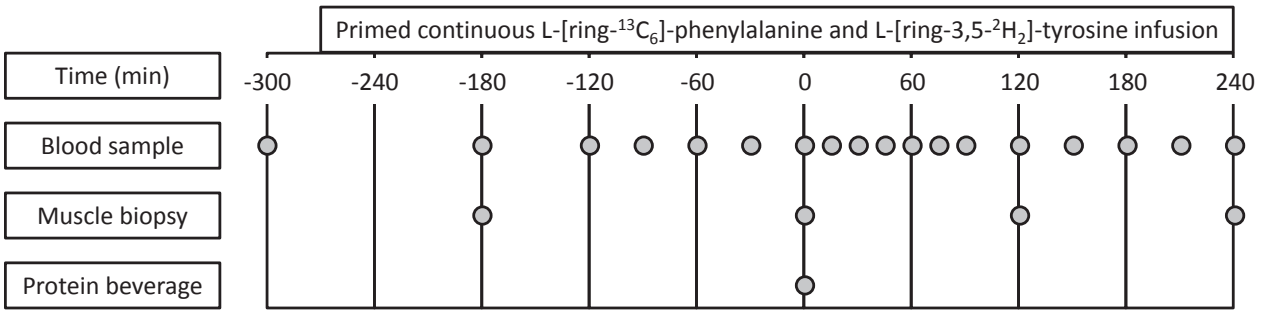

Figure 5.1 | Schematic representation of study design. After obtaining a baseline plasma sample at $\mathrm{t}=-300 \mathrm{~min}$, primed continuous infusions of $\mathrm{L}$-[ring- ${ }^{13} \mathrm{C}_{6}$ ]-phenylalanine and $\mathrm{L}$-[ring- $-3,5-{ }^{2} \mathrm{H}_{2}$ ]-tyrosine were started. Plasma samples were obtained at regular time points. After $1.5 \mathrm{~h}$ of infusion the first biopsy was obtained from the vastus lateralis. $3 \mathrm{~h}$ later the second muscle biopsy was obtained from the same leg to determine basal muscle protein synthesis rates. Immediately after the second muscle biopsy, subjects consumed one out of 5 different protein beverages. The third and fourth muscle biopsy were obtained from the contralateral leg at 2 and $4 \mathrm{~h}$ after protein intake to assess the muscle protein synthetic response to protein ingestion over the early $(0-2 \mathrm{~h})$, late (2-4 h), and entire (0-4 h) postprandial period.

\section{PLASMA ANALYSES}

Plasma glucose and insulin concentrations were analyzed using commercially available kits (Glucose HK Gen.3, Roche, Ref: 05168791190 , and Elecsys Insulin assay, Roche, Ref: 12017547122, respectively). For determination of plasma concentrations of all essential and non-essential amino acids, $10 \mu \mathrm{L}$ plasma was mixed with $1500 \mu \mathrm{L} 0.5 \mathrm{mM}$ tridecafluoroheptanoic acid (TDFHA; Sigma, Zwijndrecht, the Netherlands) in water and $10 \mu \mathrm{L}$ internal standard solution containing stable isotope-labeled amino acids (Cambridge Isotopes Laboratories, Andover, MA) in $0.1 \mathrm{M} \mathrm{HCl}$. Amino acid concentrations were determined using ultra-performance liquid chromatography tandem mass spectrometry (UPLC-MS/MS) as described previously (24). Plasma amino acid concentrations and enrichments were determined by gas chromatography-mass spectrometry (GC-MS; Agilent 7890A GC/5975C; MSD, Wilmington, Delaware, USA). Specifically, the internal standards $\left[\mathrm{U}^{13} \mathrm{C}_{6}\right]-$ leucine, $\left[\mathrm{U}-{ }^{13} \mathrm{C}_{9}{ }^{15} \mathrm{~N}\right]$-phenylalanine, and $\left[\mathrm{U}-{ }^{13} \mathrm{C}_{9}{ }^{15} \mathrm{~N}\right]$-tyrosine were added to the plasma sample. The plasma was deproteinized with 5-sulfosalicylic acid. Free amino acids were purified using cation exchange AG 50W-X8 resin (mesh size: 100-200, ionic form: hydrogen (Bio-Rad Laboratories, Hercules, CA)) columns. The purified amino acids were converted into tert-butyldimethylsilyl (tert- 
BDMS) derivatives with MTBSTFA before analysis by GC-MS. The amino acid concentrations were determined using electron impact ionization by monitoring ions at mass/charge $(\mathrm{m} / \mathrm{z}) 302$ and 308 for unlabeled and $\left[\mathrm{U}-{ }^{13} \mathrm{C}_{6}\right]$-leucine, 336 and 346 for unlabeled and $\left[\mathrm{U}-{ }^{13} \mathrm{C}_{9}{ }^{15} \mathrm{~N}\right]$-phenylalanine, and 466 and 476 for unlabeled and $\left[\mathrm{U}-{ }^{13} \mathrm{C}_{9}{ }^{15} \mathrm{~N}\right]$-tyrosine, respectively. The plasma phenylalanine and tyrosine ${ }^{13} \mathrm{C}$ and ${ }^{2} \mathrm{H}$ enrichments were determined using selective ion monitoring at 336 and 342 for unlabeled and labeled ( ring ${ }^{-13} \mathrm{C}_{6}$ ) phenylalanine, respectively; $\mathrm{m} / \mathrm{z} 466,468$, and 472 for unlabeled and labeled (ring-3, $5-{ }^{2} \mathrm{H}_{2}$, and ring- ${ }^{13} \mathrm{C}_{6}$ ) tyrosine, respectively. Standard regression curves from a series of known standard enrichment values against the measured enrichment values were applied to assess linearity of the mass spectrometer and to account for isotopic fractionation.

\section{MUSCLE ANALYSES}

Myofibrillar proteins were extracted from $\sim 60 \mathrm{mg}$ wet muscle by hand-homogenizing in $7 \mu \mathrm{L} / \mathrm{mg}$ homogenization buffer using a Teflon pestle. Samples were centrifuged at $2,500 \mathrm{~g}$ for $5 \mathrm{~min}$ at $4^{\circ} \mathrm{C}$. The pellet was washed with $500 \mu \mathrm{L} \mathrm{ddH}_{2} \mathrm{O}$ and centrifuged at $250 \mathrm{~g}$ for $10 \mathrm{~min}$ at $4^{\circ} \mathrm{C}$. The myofibrillar proteins in the pellet were solubilized by adding $1 \mathrm{~mL} 0.3 \mathrm{M} \mathrm{NaOH}$ and heating at $50^{\circ} \mathrm{C}$ for $30 \mathrm{~min}$ with vortex mixing every $10 \mathrm{~min}$. Samples were centrifuged at $12,000 \mathrm{~g}$ for $5 \mathrm{~min}$ at $4^{\circ} \mathrm{C}$. The supernatant containing the myofibrillar proteins was collected and the collagen pellet was discarded. Myofibrillar proteins were precipitated by adding $1 \mathrm{~mL}$ of $1 \mathrm{M} \mathrm{PCA}$ and centrifuging at $1,000 \mathrm{~g}$ for $10 \mathrm{~min}$ at $4^{\circ} \mathrm{C}$. The myofibrillar protein pellet was washed twice with $1 \mathrm{~mL} 70 \%$ ethanol and hydrolyzed overnight in $2 \mathrm{~mL} 6 \mathrm{M} \mathrm{HCl}$ at $110^{\circ} \mathrm{C}$. Mixed muscle proteins were extracted from a separate piece of wet muscle ( $\sim 50 \mathrm{mg})$. Muscle tissue was freeze-dried, and collagen, blood, and other non-muscle tissue were removed under a dissecting microscope. The freeze-dried muscle was weighed $(\sim 10 \mathrm{mg})$ and homogenized in 35 volumes of ice-cold 2\% PCA using a sonicator. Samples were incubated on ice for 10 minutes. After centrifugation, the supernatant was collected for determination of L-[ring ${ }^{-13} \mathrm{C}_{6}$ ]-phenylalanine enrichments in the intracellular precursor pool using GC-MS analysis (see Plasma analyses). The mixed muscle protein pellet was washed three times with $1 \mathrm{~mL}$ ice-cold $2 \%$ PCA and hydrolyzed in $3 \mathrm{~mL} 6 \mathrm{M} \mathrm{HCl}$ overnight at $120^{\circ} \mathrm{C}$. The free amino acids from the hydrolyzed myofibrillar and mixed muscle protein pellet were dried under nitrogen stream while being heated to $120^{\circ} \mathrm{C}$. The free amino acids were then dissolved in $25 \%$ acetic acid solution, passed over cation exchange AG 50W-X8 resin columns (mesh size: 100-200, ionic form: hydrogen (Bio-Rad Laboratories, Hercules, CA, USA)), and eluted with $2 \mathrm{M} \mathrm{NH}_{4} \mathrm{OH}$. To determine myofibrillar and mixed muscle protein $\mathrm{L}$-[ring- ${ }^{13} \mathrm{C}_{6}$-phenylalanine enrichments by gas chromatography-combustion-isotope ratio mass spectrometry (GC-C-IRMS) analysis, the purified amino acids were converted into $\mathrm{N}$-ethoxycarbonyl ethyl ester derivatives with ethyl chloroformate (ECF). The derivatives were then measured by GC-C-IRMS (Finnigan MAT 253, Bremen, Germany) using a DB5-MS-column (no. 122-5532; Agilent J+W scientific GC Column), GC Isolink, and monitoring of ion masses 44,45 and 46 . Standard regression curves were applied to assess the linearity of the mass spectrometer and to account for isotopic fractionation.

\section{CALCULATIONS}

Intravenous infusions of L-[ring- ${ }^{13} \mathrm{C}_{6}$ ]-phenylalanine and L-[ring-3, $\left.5-{ }^{2} \mathrm{H}_{2}\right]$-tyrosine combined with arterialized blood sampling allowed us to assess whole-body amino acid kinetics in non-steady state conditions. Total rate of appearance $\left(R_{a}\right)$, total rate of disappearance $\left(R_{d}\right)$, oxidation and synthesis rates were calculated using modified Steele's equations $(25,26)$ : 
Total $R_{a}=\frac{F_{i v}-\left[p V \times C(t) \times \frac{d E_{i v}}{d t}\right]}{E_{i v}(t)}$

Total $R_{d}=$ Total $R_{a}-p V \times \frac{d C}{d t}$

Phe hydroxylation $=$ Tyr $R_{a} \times \frac{E_{T y r}(t)}{E_{P h e}(t)} \times \frac{\text { Phe } R_{d}}{\left(F_{P h e}+P h e R_{d}\right)}$

Protein synthesis $=$ Total $R_{d}-$ Phe hydroxylation

Total $R_{a}$ represents the rate at which both dietary protein-derived phenylalanine as well as phenylalanine derived from whole-body protein breakdown enters the circulation. $F_{i v}$ is the intravenous $\mathrm{L}$-[ring- ${ }^{13} \mathrm{C}_{6}$ ]-phenylalanine infusion rate $\left(\mu \mathrm{mol} \cdot \mathrm{kg}^{-1} \cdot \mathrm{min}^{-1}\right) ; p V\left(0.125 \mathrm{~L}^{-\mathrm{kg}^{-1}}\right)$ is the distribution volume $(25) ; C(t)$ is the mean plasma phenylalanine concentration between two consecutive time points; $d E_{i v} / d t$ is the time-dependent variation in plasma L-[ring $\left.{ }^{13} C_{6}\right]-$ phenylalanine enrichments; and $E_{i v}(t)$ is the mean plasma L-[ring ${ }^{13} \mathrm{C}_{6}$ ]-phenylalanine enrichment between two consecutive time points. Total $R_{d}$ represents the rate of phenylalanine hydroxylation (first step in phenylalanine oxidation) plus the rate of phenylalanine utilization for protein synthesis. $d C / d t$ is the time-dependent variation in plasma phenylalanine concentrations. $T y r R_{a}$ is the total rate of tyrosine appearance based on the intravenous L-[ring-3,5- ${ }^{2} \mathrm{H}_{2}$-tyrosine infusion, plasma L-[ring-3,5- ${ }^{2} \mathrm{H}_{2}$ ]-tyrosine enrichments, and plasma tyrosine concentrations; $E_{T y r}(t)$ and $E_{\text {Phe }}(t)$ represent the mean plasma $\mathrm{L}$-[ring- ${ }^{13} \mathrm{C}_{6}$ ]-tyrosine and $\mathrm{L}$-[ring $\left.-{ }^{13} \mathrm{C}_{6}\right]$-phenylalanine enrichment between 2 consecutive time points, respectively; Phe $R_{d}$ is the total rate of phenylalanine disappearance; and $F_{P h e}$ is the intravenous infusion rate of $\mathrm{L}$-[ring $\left.{ }^{13} \mathrm{C}_{6}\right]$-phenylalanine $(\mu \mathrm{mol} \cdot \mathrm{kg}$ $\left.{ }^{1} \cdot \min ^{-1}\right)$.

Myofibrillar and mixed muscle protein fractional synthetic rates (FSR) were calculated using the standard precursor-product equation:

$F S R=\frac{\Delta E_{p}}{E_{\text {precursor }} \cdot t} \cdot 100 \%$

$\Delta E_{p}$ is the increment in myofibrillar or mixed muscle protein-bound L-[ring $-{ }^{13} \mathrm{C}_{6}$ ]-phenylalanine enrichment after an incorporation period; $E_{\text {precursor }}$ is the weighted mean plasma or intracellular L[ring ${ }^{13} \mathrm{C}_{6}$ ]-phenylalanine enrichment during that incorporation period; and $t$ is the incorporation period (h). For basal FSR, muscle biopsies at $\mathrm{t}=-180$ and 0 min were used, and for postprandial FSR, biopsies at $\mathrm{t}=0,120$, and 240 min were used.

\section{STATISTICS}

All data are expressed as mean \pm SEM. For plasma time curves, repeated measures ANOVA with treatment, time, and their interaction was used to identify differences between treatments over time. When significant interaction or treatment effects were observed, post hoc analysis was performed to locate these differences. For muscle parameters, ANCOVA with basal as covariate and time and treatment as factors was used to identify differences between treatments. Statistical significance was set at $\mathrm{P}<0.05$. All calculations were performed using IBM SPSS Statistics (version 21). 


\section{RESULTS}

INTACT VERSUS HYDROLYZED WHEAT PROTEIN

Postprandial plasma concentrations of the essential amino acids are presented in Figure 5.2. Plasma concentrations of histidine, isoleucine, leucine, lysine, phenylalanine, threonine, tryptophan, valine, and the sum of essential amino acids increased after protein ingestion $(\mathrm{P}<0.001)$ and did not differ between intact when compared with hydrolyzed wheat protein (TimexTreatment $P>0.05$ ). Plasma methionine concentrations increased to a greater extent after the ingestion of intact wheat protein when compared with hydrolyzed wheat protein (TimexTreatment $\mathrm{P}<0.001$ ). 
A

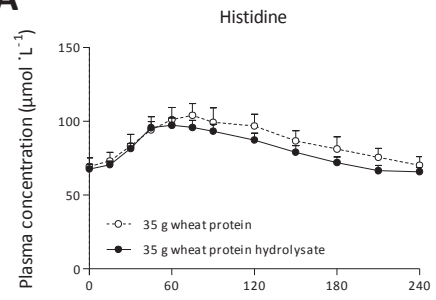

C

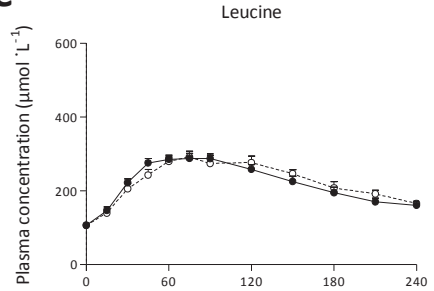

E

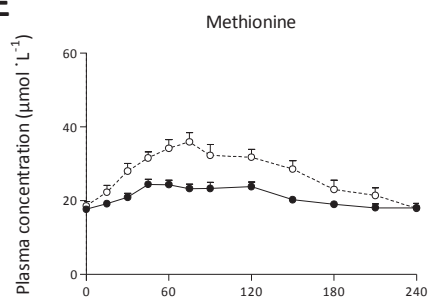

G

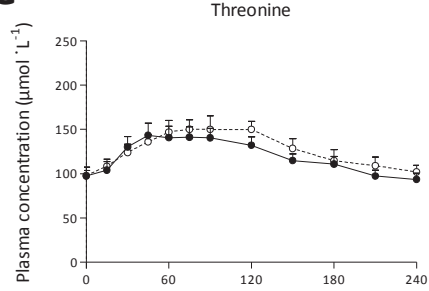

I

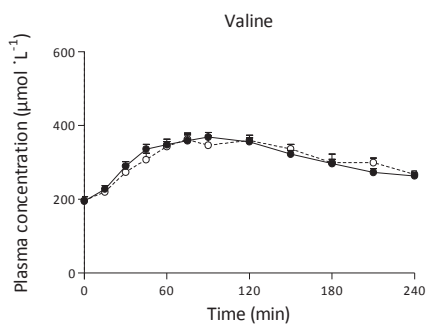

B

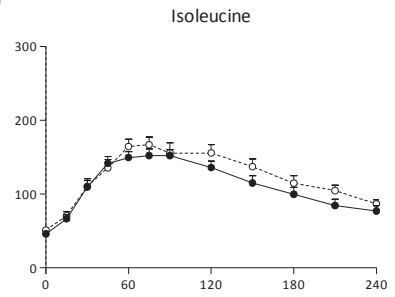

D

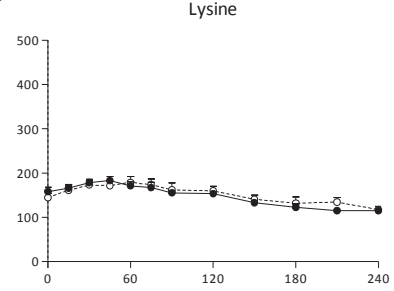

F

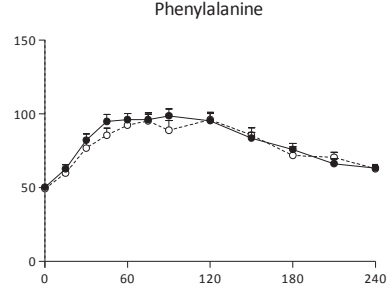

H

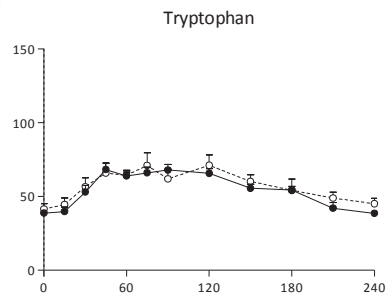

J

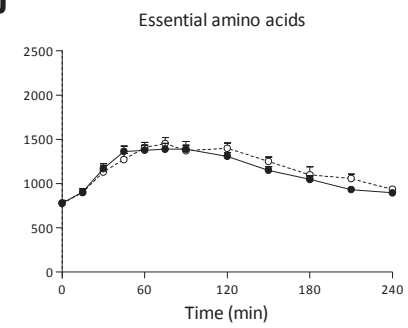

Figure 5.2 Mean ( $($ SEM) plasma histidine $(A)$, isoleucine $(B)$, leucine $(C)$, lysine $(D)$, methionine $(E)$, phenylalanine $(F)$, threonine $(G)$, tryptophan $(H)$, valine $(I)$, and essential amino acid $(J)$ concentrations $\left(\mu \mathrm{mol} \cdot \mathrm{L}^{-1}\right)$ following the ingestion of $35 \mathrm{~g}$ wheat protein $(n=12)$ or wheat protein hydrolysate $(n=12)$ in healthy older males. A-D, F-J: Time $P<0.001$, TimexTreatment $\mathrm{P}>0.05$. E: TimexTreatment $\mathrm{P}<0.001$. 
Figure 5.3 shows plasma leucine and phenylalanine concentrations as well as L-[ring $\left.{ }^{13} \mathrm{C}_{6}\right]-$ phenylalanine enrichments as measured by GC-MS for the calculation of whole-body amino acid kinetics. Plasma leucine and phenylalanine concentrations increased after protein ingestion to a similar extent in both groups (TimexTreatment $\mathrm{P}>0.05$ ). Plasma L-[ring- $\left.{ }^{13} \mathrm{C}_{6}\right]$-phenylalanine enrichments transiently declined after protein intake $(P<0.001)$, with no differences between the intact and hydrolyzed wheat protein $(P=0.46)$.

A

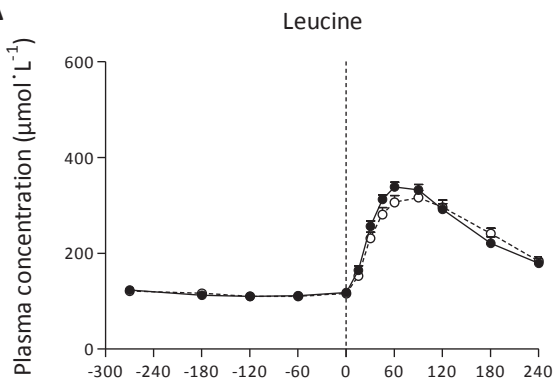

C

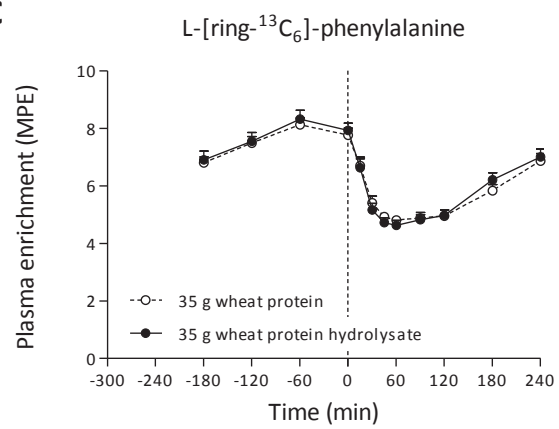

B

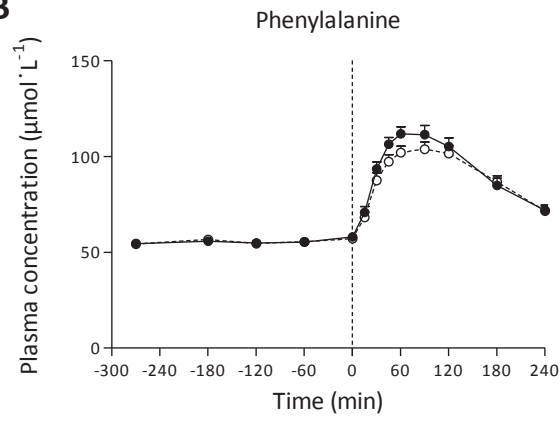

Figure 5.3 | Mean $\left( \pm\right.$ SEM) plasma leucine $(A)$ and phenylalanine $(B)$ concentrations $\left(\mu m o l \cdot L^{-1}\right)$ and $L-\left[\right.$ ring $\left.^{-13} C_{6}\right]$ phenylalanine (C) enrichments (MPE) during the fasted state and following the ingestion of $35 \mathrm{~g}$ wheat protein $(\mathrm{n}=12)$ or wheat protein hydrolysate $(n=12)$ in healthy older males. A-C: Time $P<0.001$, TimexTreatment $P>0.05$.

Total phenylalanine appearance rates increased after the ingestion of both intact and hydrolyzed wheat protein $(P<0.001)$, with no differences between treatments (TimexTreatment $P=0.32$; Figure 5.4A). The postprandial muscle protein synthetic response as assessed over the $0-4 \mathrm{~h}$ postprandial period did not differ between intact and hydrolyzed wheat protein ( $P=0.65$; Figure 5.4B). 
A

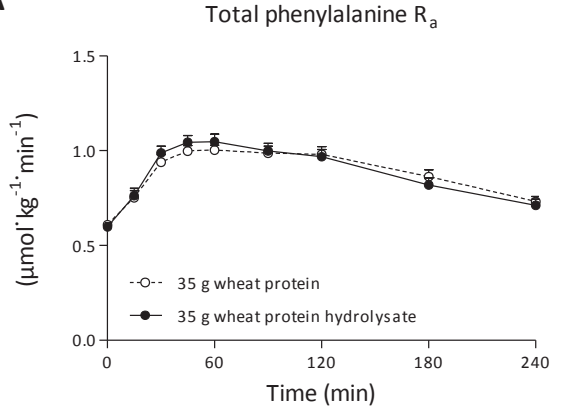

B

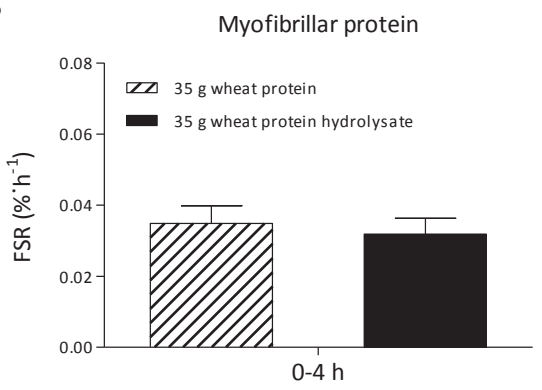

Figure 5.4 | Mean ( \pm SEM) whole-body total phenylalanine rate of appearance $\left(\mathrm{Ra}_{\mathrm{a}} ; \mu \mathrm{mol} \cdot \mathrm{kg}^{-1} \cdot \mathrm{min}^{-1} ; \mathrm{A}\right)$ and myofibrillar protein fractional synthetic rates (FSR) calculated based on the plasma precursor pool $\left(\% \cdot \mathrm{h}^{-1} ; \mathrm{B}\right)$ after the ingestion of $35 \mathrm{~g}$ wheat protein $(n=12)$ or wheat protein hydrolysate $(n=12)$ in healthy older males. A: Time $P<0.001$, TimexTreatment $\mathrm{P}=0.319$. B: Treatment $\mathrm{P}=0.653$.

\section{WHEAT PROTEIN HYDROLYSATE VERSUS DAIRY PROTEIN}

The postprandial rise in plasma essential amino acid concentrations was greater after the ingestion of whey protein when compared with wheat protein hydrolysate and casein (TimexTreatment $\mathrm{P}<0.001$; Figure 5.5J). Moreover, casein ingestion resulted in more prolonged hyperaminoacidemia when compared with wheat protein hydrolysate (TimexTreatment $\mathrm{P}<0.001$ ). Postprandial plasma lysine and methionine concentrations were different between all three treatments and were higher following whey protein ingestion and lower following the ingestion of wheat protein hydrolysate (TimexTreatment $\mathrm{P}<0.001$; Figure 5.5D and $\mathrm{E}$ ). A complete overview of all essential amino acid concentrations is presented in Figure 5.5 . 
A

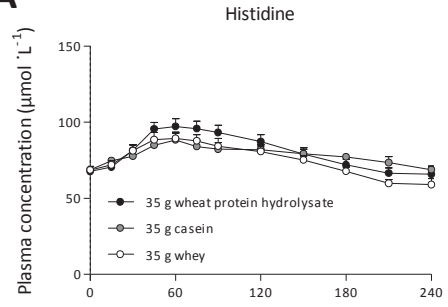

C

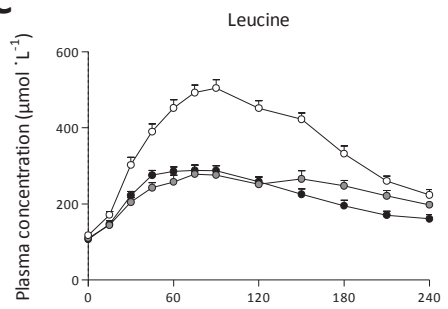

E

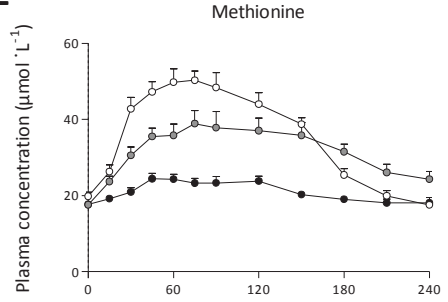

G

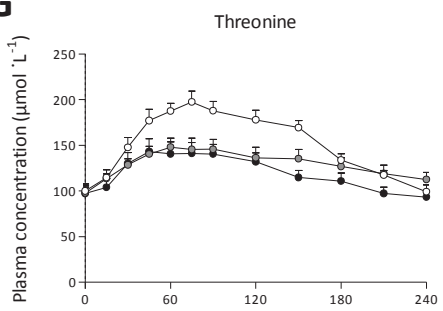

I

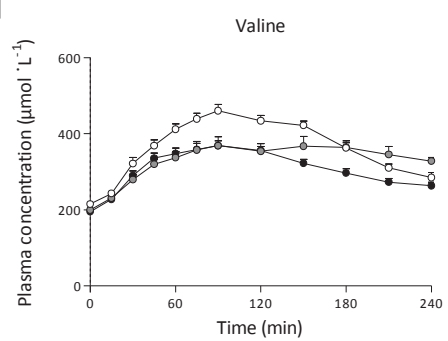

B

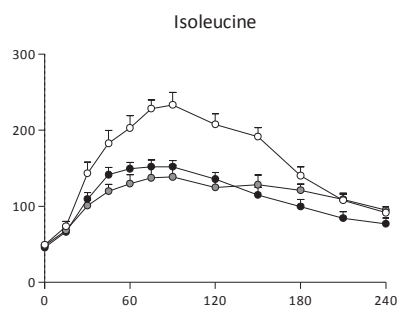

D

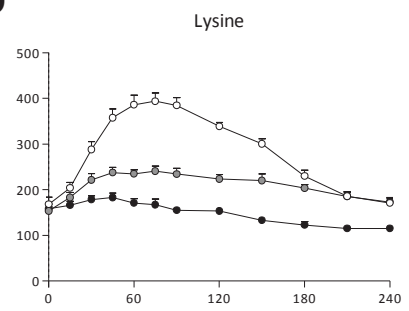

F

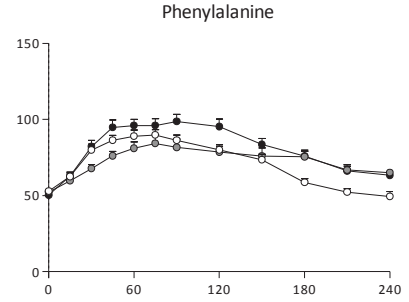

H

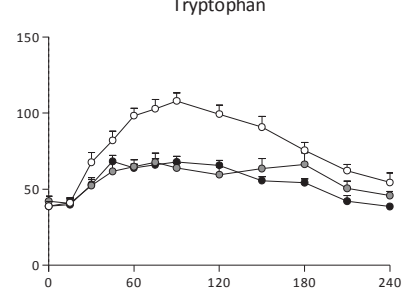

J

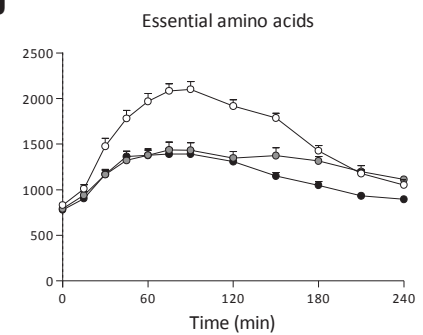

Figure 5.5 | Mean ( $($ SEM) plasma histidine $(A)$, isoleucine $(B)$, leucine $(C)$, lysine $(D)$, methionine $(E)$, phenylalanine $(F)$, threonine $(\mathrm{G})$, tryptophan $(\mathrm{H})$, valine $(\mathrm{I})$, and essential amino acid $(\mathrm{J})$ concentrations $\left(\mu \mathrm{mol} \cdot \mathrm{L}^{-1}\right)$ following the ingestion of $35 \mathrm{~g}$ wheat protein hydrolysate $(n=12)$, casein $(n=12)$, or whey $(n=12)$ in healthy older males. A: TimexTreatment $P=0.017$. B-J: TimexTreatment $\mathrm{P}<0.001$. 
Figure 5.6 shows plasma leucine and phenylalanine concentrations as well as L-[ring- $\left.{ }^{13} \mathrm{C}_{6}\right]-$ phenylalanine enrichments as measured by GC-MS for the calculation of whole-body amino acid kinetics. Plasma leucine concentrations increased to a greater extent after the ingestion of whey protein when compared with casein and hydrolyzed wheat protein (TimexTreatment $\mathrm{P}<0.001$ ). The ingestion of hydrolyzed wheat protein resulted in a slightly greater but more transient rise in plasma leucine concentrations when compared with casein (TimexTreatment $P<0.001$ ). Postprandial plasma phenylalanine concentrations were significantly higher following hydrolyzed wheat protein ingestion when compared with whey protein (TimexTreatment $\mathrm{P}<0.001$ ). Casein ingestion resulted in a slightly lower but more prolonged rise in plasma phenylalanine concentrations when compared with whey protein ingestion (TimexTreatment $\mathrm{P}<0.001$ ). The dilution in plasma L-[ring- ${ }^{13} \mathrm{C}_{6}$ ]-phenylalanine enrichments was reflective of the increase in plasma phenylalanine concentrations, with the greatest dilution following the ingestion of wheat protein hydrolysate when compared to casein and whey protein (TimexTreatment $\mathrm{P}<0.001$ ).

A

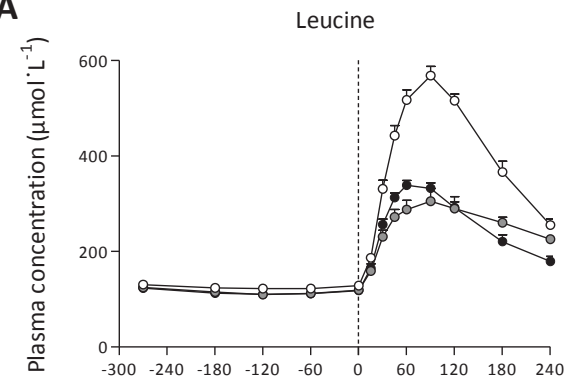

C

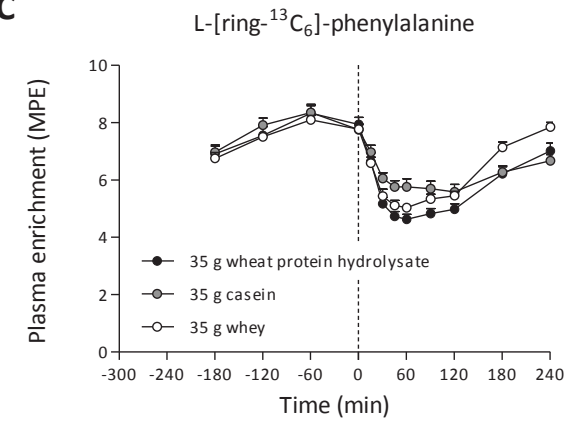

B

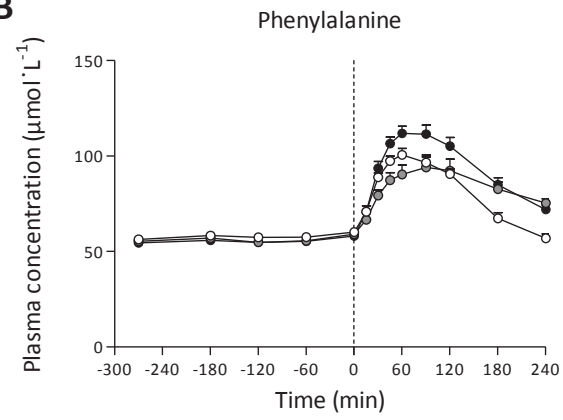

Figure 5.6 | Mean ( \pm SEM) plasma leucine $(A)$ and phenylalanine $(B)$ concentrations $\left(\mu m o l \cdot L^{-1}\right)$ and $L-\left[\right.$ ring- $\left.{ }^{13} C_{6}\right]$ phenylalanine $(C)$ enrichments (MPE) during the fasted state and following the ingestion of $35 \mathrm{~g}$ wheat protein hydrolysate $(n=12)$, casein $(n=12)$, or whey $(n=12)$ in healthy older males. A-C: TimexTreatment $P<0.001$.

Whole-body phenylalanine kinetics is shown in Figure 5.7. Total phenylalanine appearance rates, total phenylalanine disappearance rates, and phenylalanine utilization for protein synthesis increased after protein ingestion, with a greater increase following wheat protein hydrolysate, a moderate increase following whey protein, and a lower but more prolonged elevation following casein ingestion (TimexTreatment $\mathrm{P}<0.001$ ). Phenylalanine oxidation was higher after the ingestion of wheat protein hydrolysate, reached similar peak values after the ingestion of casein and whey protein, and remained elevated for a longer time period after casein ingestion (TimexTreatment $\mathrm{P}=0.001$ ). 
A

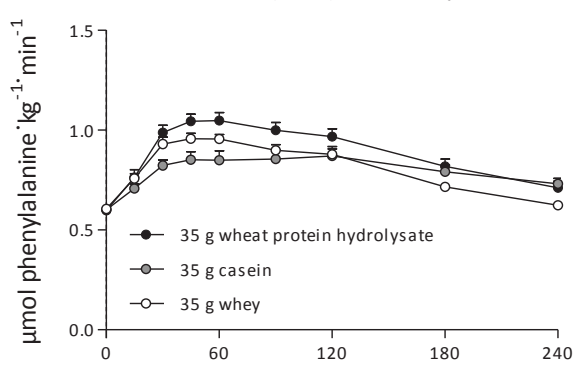

C

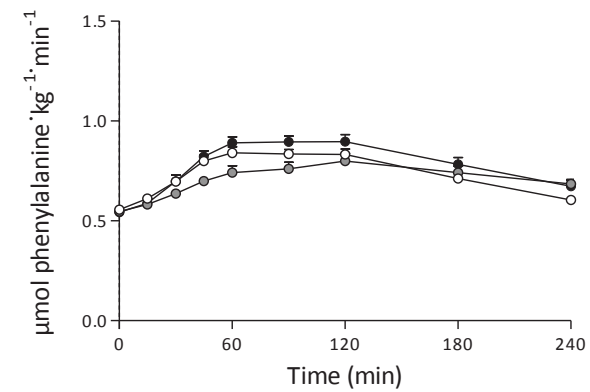

B Total phenylalanine $R_{d}$

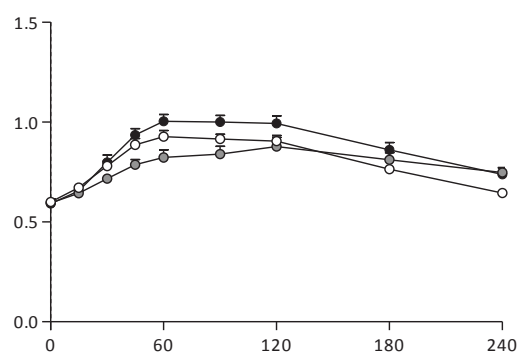

D

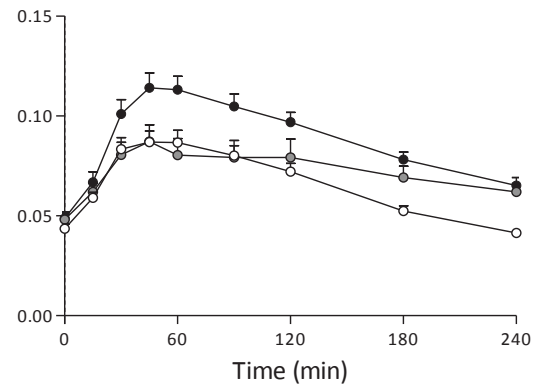

Figure 5.7 | Whole-body phenylalanine kinetics. Mean $( \pm S E M)$ total rate of appearance $\left(R_{a} ; A\right)$, total rate of disappearance $\left(R_{d} ; B\right)$, synthesis $(C)$, and oxidation $(D)$ rates $\left(\mu \mathrm{mol} \cdot \mathrm{kg}^{-1} \cdot \mathrm{min}^{-1}\right)$ following the ingestion of $35 \mathrm{~g}$ wheat protein hydrolysate $(n=12)$, casein $(n=12)$, or whey $(n=12)$ in healthy older males. A-C: TimexTreatment $P<0.001, D$ : TimexTreatment $P=0.001$.

Myofibrillar protein synthesis rates calculated based on the plasma precursor pool (Figure 5.8) increased from basal rates after the ingestion of casein when assessed over the late $(2-4 \mathrm{~h})$ and entire ( $0-4 \mathrm{~h}$ ) postprandial period (Time $\mathrm{P}=0.007$ and $\mathrm{P}=0.008$, respectively). The ingestion of $35 \mathrm{~g}$ whey protein or wheat protein hydrolysate did not significantly stimulate muscle protein synthesis rates above basal values $(P=0.12$ and $P=0.25$, respectively). Postprandial muscle protein synthesis rates were higher after the ingestion of casein when compared with wheat protein hydrolysate when assessed over the early ( $0-2 \mathrm{~h}$ ) and entire ( $0-4 \mathrm{~h}$ ) postprandial period (Treatment $\mathrm{P}=0.027$ and $\mathrm{P}=0.011$, respectively). Similar responses were observed using the mixed muscle protein fraction and when muscle protein synthesis rates were calculated based on the intracellular precursor pool (data not shown). 


\section{Myofibrillar protein}

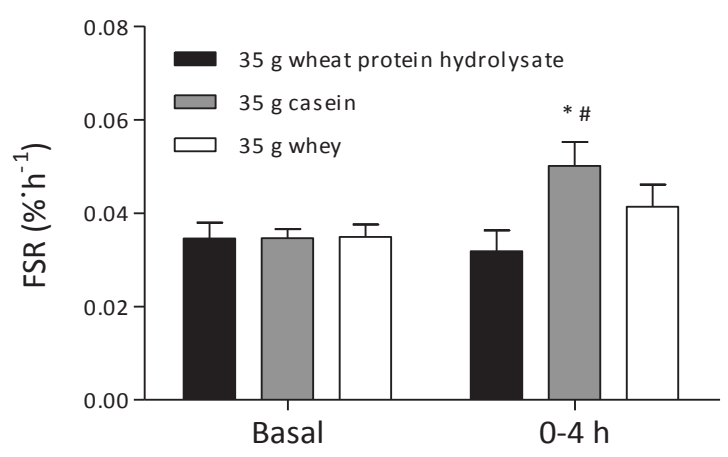

Figure 5.8 | Mean $\left( \pm\right.$ SEM) myofibrillar protein fractional synthetic rates $\left(F S R ; \% \cdot h^{-1}\right)$, calculated based on the plasma precursor pool, during the fasted state (Basal) and after the ingestion of $35 \mathrm{~g}$ wheat protein hydrolysate ( $\mathrm{n}=12$ ), casein $(n=12)$, or whey $(n=12)$ in healthy older males. ANCOVA $P=0.041$. * Significantly different from basal. \# Significantly different from wheat protein hydrolysate.

\section{LEUCINE-MATCHED AMOUNTS OF WHEY PROTEIN VERSUS WHEAT PROTEIN HYDROLYSATE}

The postprandial rise in plasma concentrations of isoleucine, leucine, lysine, methionine, threonine, tryptophan, valine, and the sum of essential amino acids was greater after ingesting whey protein when compared with a leucine-matched amount of hydrolyzed wheat protein (TimexTreatment $\mathrm{P}<0.001$; Figure 5.9). Plasma histidine and phenylalanine concentrations increased to a greater extent after the ingestion of wheat protein hydrolysate compared to whey protein (TimexTreatment $\mathrm{P}<0.001$ ). 
A

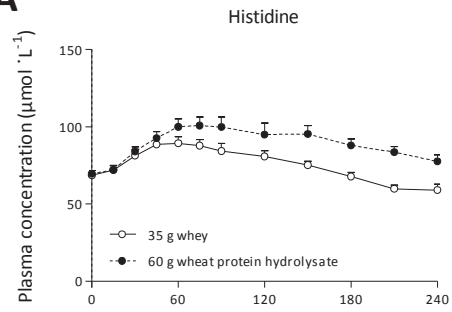

C

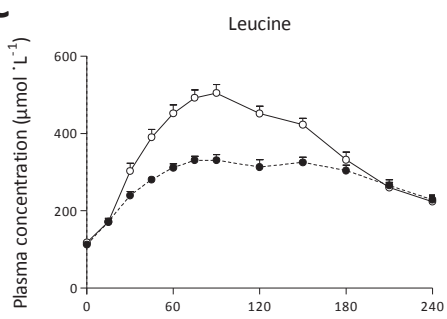

E

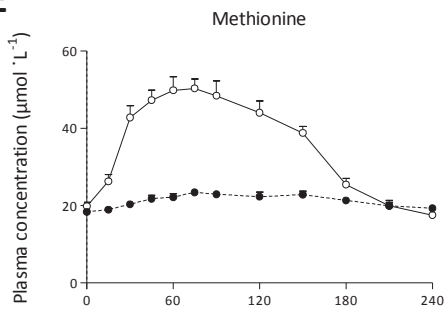

G

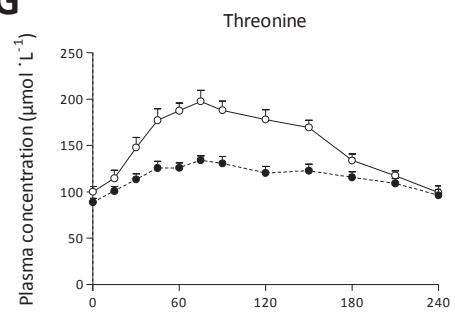

I

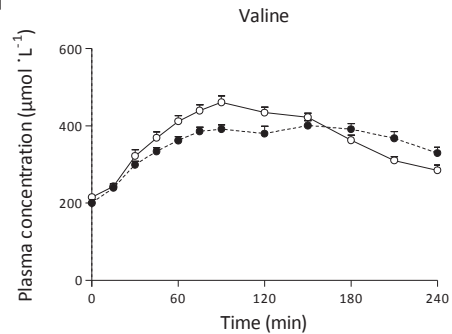

B

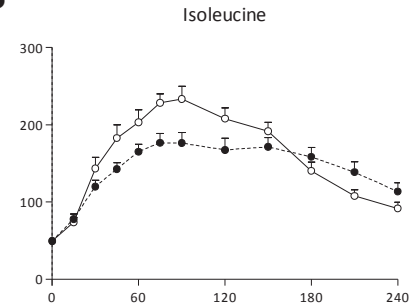

D

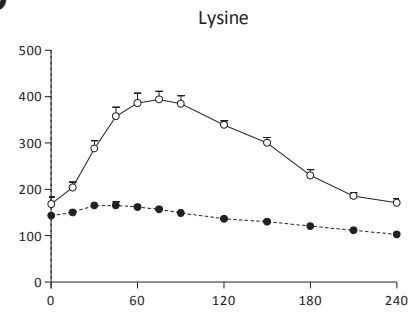

F

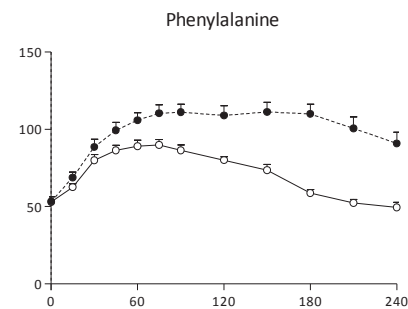

H

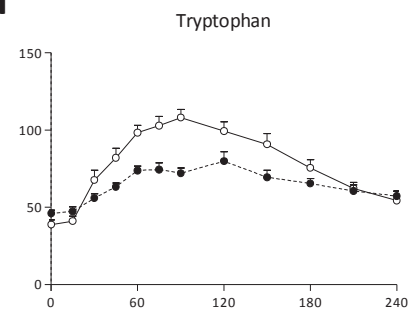

J
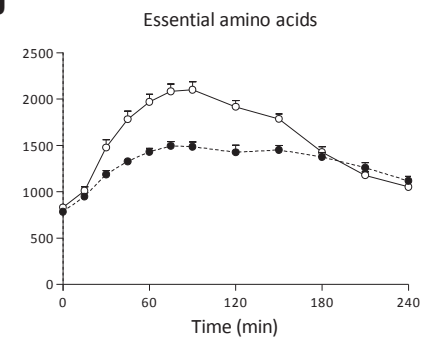

Figure 5.9 | Mean ( $($ SEM) plasma histidine $(A)$, isoleucine $(B)$, leucine $(C)$, lysine $(D)$, methionine $(E)$, phenylalanine $(F)$, threonine $(\mathrm{G})$, tryptophan $(\mathrm{H})$, valine $(\mathrm{I})$, and essential amino acid $(\mathrm{J})$ concentrations $\left(\mu \mathrm{mol} \cdot \mathrm{L}^{-1}\right)$ following the ingestion of $35 \mathrm{~g}$ whey $(n=12)$ or a leucine-matched amount (i.e., $60 \mathrm{~g})$ of wheat protein hydrolysate $(n=12)$ in healthy older males. AJ: TimexTreatment $\mathrm{P}<0.001$. 
Figure 5.10 shows plasma leucine and phenylalanine concentrations as well as L-[ring $\left.{ }^{13} \mathrm{C}_{6}\right]-$ phenylalanine enrichments as measured by GC-MS for the calculation of whole-body amino acid kinetics. Despite equal leucine content, plasma leucine concentrations increased to a greater extent after the ingestion of whey protein when compared with wheat protein (TimexTreatment $\mathrm{P}<0.001$ ). Plasma phenylalanine concentrations increased to a greater extent and remained elevated for a more prolonged period after the ingestion of wheat protein hydrolysate compared to whey protein (TimexTreatment $\mathrm{P}<0.001$ ). The postprandial dilution in plasma $\mathrm{L}-\left[\mathrm{ring}{ }^{-13} \mathrm{C}_{6}\right]-$ phenylalanine enrichments was reflective of the increase in plasma phenylalanine concentrations, with a more prolonged dilution following hydrolyzed wheat protein ingestion (TimexTreatment $\mathrm{P}<0.001)$.

A

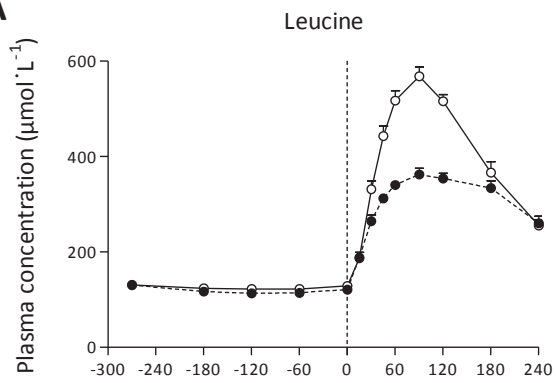

C

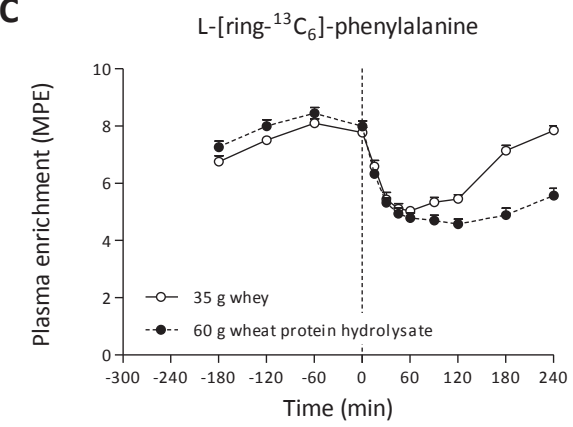

B

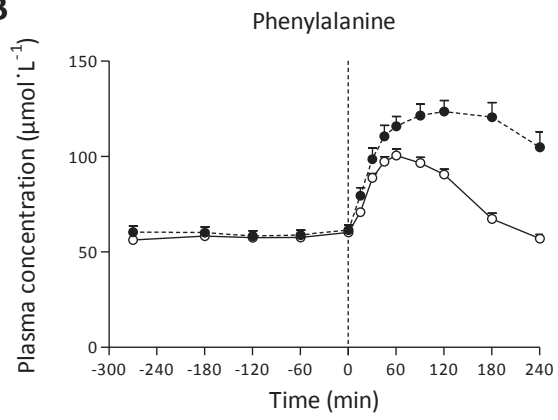

Figure 5.10 | Mean ( \pm SEM) plasma leucine $(A)$ and phenylalanine $(B)$ concentrations $\left(\mu \mathrm{mol} \cdot \mathrm{L}^{-1}\right)$ and $\mathrm{L}-\left[\right.$ ring $\left.^{-13} \mathrm{C}_{6}\right]$ phenylalanine (C) enrichments (MPE) during the fasted state and following the ingestion of $35 \mathrm{~g}$ whey $(\mathrm{n}=12)$ or a leucine-matched amount (i.e., $60 \mathrm{~g})$ of wheat protein hydrolysate $(n=12)$ in healthy older males. A-C: TimexTreatment $\mathrm{P}<0.001$.

Total phenylalanine appearance rates, total phenylalanine disappearance rates, and phenylalanine utilization for protein synthesis increased after the ingestion of both whey and wheat protein, with a more prolonged elevation following hydrolyzed wheat protein ingestion (TimexTreatment $\mathrm{P}<0.001$; Figure 5.11). Phenylalanine oxidation increased to a greater extent and remained elevated for a longer time period after the ingestion of wheat protein hydrolysate compared to whey protein (TimexTreatment $\mathrm{P}<0.001$ ). 
A

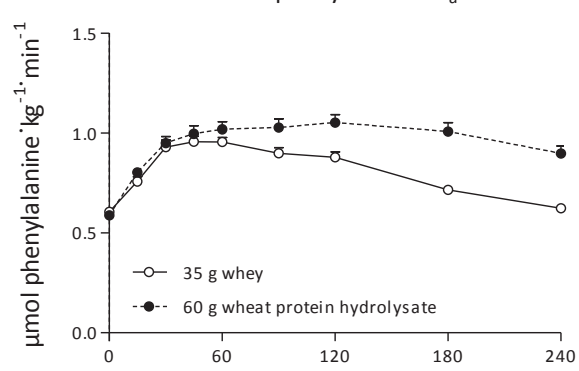

C

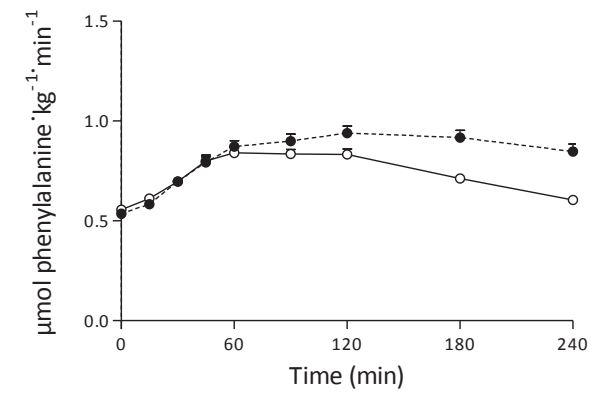

B Total phenylalanine $R_{d}$

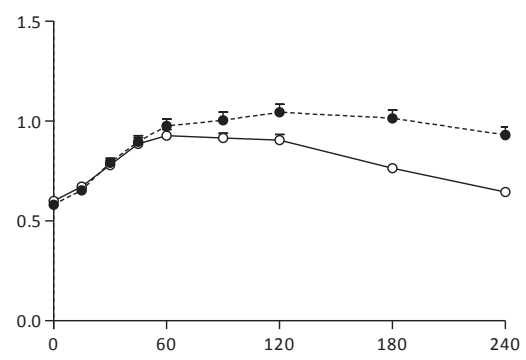

D

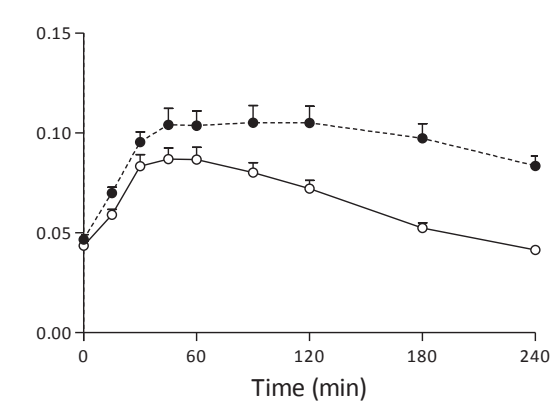

Figure 5.11 | Whole-body phenylalanine kinetics. Mean $( \pm S E M)$ total rate of appearance $\left(R_{a} ; A\right)$, total rate of disappearance $\left(R_{d} ; B\right)$, synthesis $(C)$, and oxidation $(D)$ rates $\left(\mu \mathrm{mol} \cdot \mathrm{kg}^{-1} \cdot \mathrm{min}^{-1}\right)$ following the ingestion of $35 \mathrm{~g}$ whey $(n=12)$ or a leucine-matched amount (i.e., $60 \mathrm{~g})$ of wheat protein hydrolysate $(n=12)$ in healthy older males. A-D: TimexTreatment $\mathrm{P}<0.001$.

Myofibrillar protein synthesis rates calculated based on the plasma precursor pool (Figure 5.12) increased from basal rates after the ingestion of $60 \mathrm{~g}$ wheat protein hydrolysate when assessed over the late $(2-4 \mathrm{~h}$ ) and entire $(0-4 \mathrm{~h})$ postprandial period (Time $\mathrm{P}<0.001$ and $\mathrm{P}=0.017$, respectively), and did not increase from basal rates after the ingestion of $35 \mathrm{~g}$ whey protein (Time $\mathrm{P}=0.11$ ). Similar responses were observed using the mixed muscle protein fraction and when muscle protein synthesis rates were calculated based on the intracellular precursor pool (data not shown). 


\section{Myofibrillar protein}

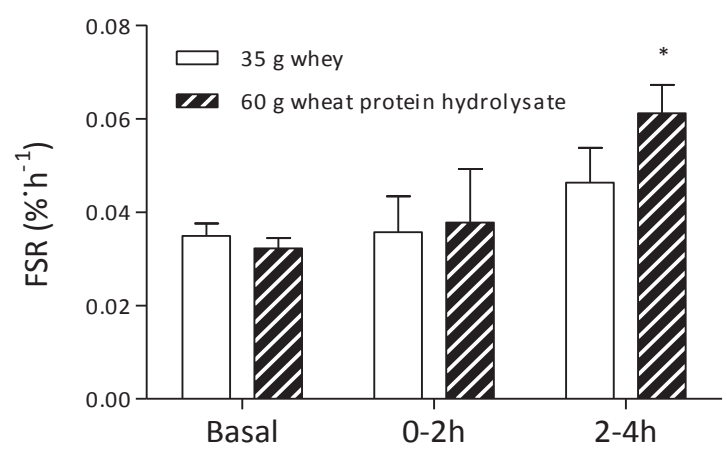

Figure 5.12 | Mean ( \pm SEM) myofibrillar protein fractional synthetic rates $\left(\mathrm{FSR} ; \% \cdot \mathrm{h}^{-1}\right)$, calculated based on the plasma precursor pool, during the fasted state (Basal) and after the ingestion of $35 \mathrm{~g}$ whey $(n=12)$ or a leucine-matched amount (i.e., $60 \mathrm{~g}$ ) of wheat protein hydrolysate $(n=12)$ in healthy older males. TimexTreatment $P=0.366$, Treatment $P=0.347$. * Significantly different from basal. 


\section{Discussion}

In the present study we observed no differences in the postprandial rise in plasma amino acid concentrations and postprandial muscle protein synthesis rates following the ingestion of $35 \mathrm{~g}$ intact wheat protein versus $35 \mathrm{~g}$ hydrolyzed wheat protein. Next, we observed that ingestion of 35 $\mathrm{g}$ casein resulted in greater postprandial muscle protein synthesis rates when compared to the ingestion of the same amount of hydrolyzed wheat protein. Ingesting $60 \mathrm{~g}$ as opposed to $35 \mathrm{~g}$ wheat protein hydrolysate increased muscle protein synthesis rates above basal, post-absorptive levels, with muscle protein synthesis rates being similar to those observed after ingesting $35 \mathrm{~g}$ casein.

As much as $\sim 60 \%$ of daily protein intake is provided by plant-based protein sources, with wheat protein representing one of the main proteins (12). Based upon the PDCAAS and DIAAS scores, wheat could be regarded as a low quality protein source when compared with animal-derived protein sources (27). However, these PDCAAS and DIAAS scores do not necessarily reflect the capacity of the various protein sources to stimulate muscle protein synthesis rates (17). The postprandial rise in muscle protein synthesis rates following protein ingestion is largely modulated by the protein digestion and absorption kinetics of a certain protein source $(28,29)$. Previously, we have demonstrated that ingestion of hydrolyzed casein, when compared with intact (micellar) casein, is followed by more rapid protein digestion and amino acid absorption, resulting in greater postprandial plasma amino acid availability and a tendency for higher postprandial muscle protein synthesis rates (7). Since hydrolyzed wheat protein concentrates have become commercially available, their application in liquid protein-dense food products has become of interest. In the current study, we compared the postprandial response to the ingestion of intact compared with hydrolyzed wheat protein. Ingestion of $35 \mathrm{~g}$ intact or hydrolyzed wheat protein was followed by a rapid rise in circulating essential amino acid concentrations, with no differences between protein types (Figure 5.2). In accordance, postprandial muscle protein synthesis rates did not differ following ingestion of intact compared with hydrolyzed wheat protein (Figure 5.4). As no differences were evident between the postprandial responses to the ingestion of intact versus hydrolyzed wheat protein, and solubility is much higher for the protein hydrolysate, it will generally be preferred to apply wheat protein hydrolysates in the development of (liquid) nutritional supplements.

Plant-based proteins generally exhibit lower digestibility when compared with animal-derived proteins (30). As such, less of the dietary protein is effectively digested and absorbed, resulting in lower postprandial availability of dietary protein-derived amino acids as precursors for de novo muscle protein synthesis (31). However, once freed from anti-nutritional compounds that interfere with protein digestion and absorption, purified plant-based proteins are likely to possess digestion and absorption kinetics that are not different from animal-derived proteins $(18,30)$. Here, we compared postprandial amino acid profiles following the ingestion of purified wheat protein hydrolysate vs casein and whey protein. Ingestion of $35 \mathrm{~g}$ wheat, casein, and whey protein rapidly increased plasma essential amino acid concentrations (Figure 5.5). Ingesting wheat protein hydrolysate resulted in similar postprandial peak essential amino acid concentrations when compared with casein ingestion, despite the lower essential amino acid content of the ingested wheat protein. However, casein ingestion resulted in a more prolonged elevation of circulating essential amino acid levels when compared with the ingestion of the same amount of wheat protein hydrolysate (Figure 5.5). The ingestion of whey protein, when compared with wheat protein hydrolysate and casein, resulted in a more prominent postprandial rise in plasma essential amino acid concentrations. Plasma lysine and methionine concentrations only marginally increased after the ingestion of wheat protein hydrolysate when compared with casein and whey 
protein, which is in agreement with the lower lysine and methionine content in wheat protein (1.5 and $0.6 \%$ ) compared with casein (7.6 and $2.1 \%$ ) and whey protein (10.1 and 2.0\%, respectively). These data imply that wheat protein hydrolysate is well digested and absorbed, with a substantial postprandial rise in plasma amino acid availability. Despite this rapid postprandial increase in circulating amino acid concentrations, we failed to detect a measureable increase in muscle protein synthesis rates following ingestion of $35 \mathrm{~g}$ wheat or whey protein (Figure 5.8). In contrast, ingestion of an equal amount of casein resulted in a $48 \pm 16 \%$ increase in muscle protein synthesis rates when compared with basal, post-absorptive values (Figure 5.8). Interestingly, we observed no differences in postprandial muscle protein synthesis rates between casein and whey protein ingestion. Most previous studies have shown that ingesting whey protein is superior to casein in the stimulation of whole-body $(28,29)$ as well as muscle $(7,9,32,33)$ protein synthesis rates. Though we can only speculate on the discrepancy between this and previous studies, potential differences between casein and whey protein may be less pronounced when ingesting $35 \mathrm{~g}$ as opposed to $20 \mathrm{~g}$ protein.

In this study, we show that the muscle protein synthetic response to the ingestion of wheat protein hydrolysate is lower when compared with the ingestion of casein. It seems likely that this is attributed to differences in amino acid composition, with the essential amino acid and leucine contents being lower in wheat protein $(\sim 10 \mathrm{~g}$ and $2.5 \mathrm{~g}$ per $35 \mathrm{~g}$ protein, respectively) when compared with casein ( 15 and $3.2 \mathrm{~g}$ per $35 \mathrm{~g}$ protein, respectively). We hypothesized that ingestion of a greater dose of wheat protein, matched for the amount of leucine present in $35 \mathrm{~g}$ whey protein, is followed by a similar postprandial rise in plasma amino acid concentrations and subsequent postprandial muscle protein synthetic response when compared with the ingestion of $35 \mathrm{~g}$ whey protein. Despite equal leucine content in the $60 \mathrm{~g}$ wheat and $35 \mathrm{~g}$ whey protein bolus (both $4.4 \mathrm{~g}$ leucine), we observed that plasma leucine concentrations increased to a greater extent after ingesting $35 \mathrm{~g}$ whey protein when compared with $60 \mathrm{~g}$ wheat protein hydrolysate (Figure 5.10). Obviously, the $60 \mathrm{~g}$ wheat protein beverage has a greater caloric density and may, therefore, have been emptied from the stomach over a longer time period, attenuating the postprandial rise in circulating amino acid concentrations (34). Nevertheless, the ingestion of $60 \mathrm{~g}$ wheat protein hydrolysate significantly increased muscle protein synthesis rates above basal, post-absorptive values (Figure 5.12). The more sustained appearance of amino acids into the circulation following ingestion of $60 \mathrm{~g}$ wheat protein hydrolysate compared to $35 \mathrm{~g}$ whey protein may have been responsible for the greater stimulation of postprandial muscle protein synthesis rates. These data provide evidence that both the type and amount of protein consumed define the postprandial muscle protein synthetic response, and that the amount consumed can be modified to match the anabolic properties of a certain protein source. Furthermore, it should be noted that the postprandial rise in plasma leucine concentrations alone does not dictate the anabolic response to protein ingestion.

Dairy proteins are very potent in the stimulation of muscle protein synthesis rates due to their high digestibility and high leucine content, but are relatively expensive. From a global sustainability and economic standpoint, there is an increasing interest in the application of plant-based proteins (17). The muscle protein synthetic response to the ingestion of plant-based protein is generally deemed inferior when compared to dairy protein ingestion $(9,10,15,16,19)$. Though this does not necessarily apply to all plant-based proteins (17), we confirm that the ingestion of $35 \mathrm{~g}$ wheat protein induces a lower muscle protein synthetic response when compared with the ingestion of the same amount of casein. However, the lesser postprandial muscle protein synthetic response may be compensated for by increasing the amount of protein ingested (Figure 5.12). A practical, cost-effective, and sustainable strategy would be to fortify plant-based protein sources with dairy 
protein to increase their anabolic properties. Recently, Reidy et al. showed that the ingestion of a soy-dairy protein blend stimulates postexercise muscle protein synthesis rates to a similar extent as a bolus of whey protein containing equal essential amino acid content $(35,36)$. These protein blends combining dairy and plant-based proteins could be applied to support muscle mass gains and/or prevent muscle mass loss, thereby supporting consumers' health in the emerging markets. We conclude that the postprandial muscle protein synthetic response to the ingestion of $35 \mathrm{~g}$ casein is greater when compared with the ingestion of the same amount of wheat protein. Ingesting a larger amount of wheat protein substantially increases myofibrillar protein synthesis rates in healthy older males. These data provide useful information when developing or optimizing food product formulations combining wheat or other plant-based proteins with dairy proteins to stimulate muscle protein synthesis rates and support muscle mass maintenance. 


\section{REFERENCES}

1. Haruna Y, Suzuki Y, Kawakubo K, Yanagibori R, Gunji A. Decremental reset in basal metabolism during 20-days bed rest. Acta physiologica Scandinavica Supplementum 1994;616:43-9.

2. Janssen I, Heymsfield SB, Ross R. Low relative skeletal muscle mass (sarcopenia) in older persons is associated with functional impairment and physical disability. Journal of the American Geriatrics Society 2002;50(5):889-96.

3. Koopman R, van Loon LJ. Aging, exercise, and muscle protein metabolism. J Appl Physiol 2009;106(6):2040-8.

4. Koopman R, Crombach N, Gijsen AP, Walrand S, Fauquant J, Kies AK, Lemosquet S, Saris WH, Boirie Y, van Loon $\mathrm{LJ}$. Ingestion of a protein hydrolysate is accompanied by an accelerated in vivo digestion and absorption rate when compared with its intact protein. Am J Clin Nutr 2009;90(1):106-15.

5. Koopman R, Walrand S, Beelen M, Gijsen AP, Kies AK, Boirie Y, Saris WH, van Loon LJ. Dietary protein digestion and absorption rates and the subsequent postprandial muscle protein synthetic response do not differ between young and elderly men. J Nutr 2009;139(9):1707-13.

6. Moore DR, Robinson MJ, Fry JL, Tang JE, Glover El, Wilkinson SB, Prior T, Tarnopolsky MA, Phillips SM. Ingested protein dose response of muscle and albumin protein synthesis after resistance exercise in young men. Am J Clin Nutr 2009;89(1):161-8.

7. Pennings B, Boirie $Y$, Senden JM, Gijsen AP, Kuipers $H$, van Loon LJ. Whey protein stimulates postprandial muscle protein accretion more effectively than do casein and casein hydrolysate in older men. Am J Clin Nutr 2011;93(5):997-1005.

8. Pennings B, Groen B, de Lange A, Gijsen AP, Zorenc AH, Senden JM, van Loon LJ. Amino acid absorption and subsequent muscle protein accretion following graded intakes of whey protein in elderly men. Am J Physiol Endocrinol Metab 2012;302(8):E992-9.

9. Tang JE, Moore DR, Kujbida GW, Tarnopolsky MA, Phillips SM. Ingestion of whey hydrolysate, casein, or soy protein isolate: effects on mixed muscle protein synthesis at rest and following resistance exercise in young men. Journal of applied physiology (Bethesda, Md : 1985) 2009;107(3):987-92.

10. Yang Y, Churchward-Venne TA, Burd NA, Breen L, Tarnopolsky MA, Phillips SM. Myofibrillar protein synthesis following ingestion of soy protein isolate at rest and after resistance exercise in elderly men. Nutr Metab (Lond) 2012;9(1):57.

11. Gorissen SH, Remond D, van Loon LJ. The muscle protein synthetic response to food ingestion. Meat science 2015.

12. FAOSTAT. Food Balance Sheets. Rome, Italy, 2011.

13. Hartman JW, Tang JE, Wilkinson SB, Tarnopolsky MA, Lawrence RL, Fullerton AV, Phillips SM. Consumption of fat-free fluid milk after resistance exercise promotes greater lean mass accretion than does consumption of soy or carbohydrate in young, novice, male weightlifters. Am J Clin Nutr 2007;86(2):373-81.

14. Luiking YC, Engelen MP, Soeters PB, Boirie Y, Deutz NE. Differential metabolic effects of casein and soy protein meals on skeletal muscle in healthy volunteers. Clin Nutr 2011;30(1):65-72.

15. Phillips SM. Nutrient-rich meat proteins in offsetting age-related muscle loss. Meat science 2012;92(3):174-8.

16. Wilkinson SB, Tarnopolsky MA, Macdonald MJ, Macdonald JR, Armstrong D, Phillips SM. Consumption of fluid skim milk promotes greater muscle protein accretion after resistance exercise than does consumption of an isonitrogenous and isoenergetic soy-protein beverage. Am J Clin Nutr 2007;85(4):1031-40.

17. van Vliet S, Burd NA, van Loon LJ. The Skeletal Muscle Anabolic Response to Plant- versus Animal-Based Protein Consumption. J Nutr 2015.

18. Sarwar Gilani G, Wu Xiao C, Cockell KA. Impact of antinutritional factors in food proteins on the digestibility of protein and the bioavailability of amino acids and on protein quality. The British journal of nutrition 2012;108 Suppl 2:S315-32.

19. Norton LE, Wilson GJ, Layman DK, Moulton CJ, Garlick PJ. Leucine content of dietary proteins is a determinant of postprandial skeletal muscle protein synthesis in adult rats. Nutr Metab (Lond) 2012;9(1):67.

20. Koopman R, Beelen M, Stellingwerff T, Pennings B, Saris WH, Kies AK, Kuipers H, van Loon LJ. Coingestion of carbohydrate with protein does not further augment postexercise muscle protein synthesis. Am J Physiol Endocrinol Metab 2007;293(3):E833-42.

21. Alberti KG, Zimmet PZ. Definition, diagnosis and classification of diabetes mellitus and its complications. Part 1: diagnosis and classification of diabetes mellitus provisional report of a WHO consultation. Diabet Med 1998;15(7):539-53.

22. Abumrad NN, Rabin D, Diamond MP, Lacy WW. Use of a heated superficial hand vein as an alternative site for the measurement of amino acid concentrations and for the study of glucose and alanine kinetics in man. Metabolism 1981;30(9):936-40.

23. Bergstrom J. Percutaneous needle biopsy of skeletal muscle in physiological and clinical research. Scand J Clin Lab Invest 1975;35(7):609-16.

24. Waterval WA, Scheijen JL, Ortmans-Ploemen MM, Habets-van der Poel CD, Bierau J. Quantitative UPLC-MS/MS analysis of underivatised amino acids in body fluids is a reliable tool for the diagnosis and follow-up of patients with inborn errors of metabolism. Clin Chim Acta 2009;407(1-2):36-42.

25. Boirie Y, Gachon P, Corny S, Fauquant J, Maubois JL, Beaufrere B. Acute postprandial changes in leucine metabolism as assessed with an intrinsically labeled milk protein. Am J Physiol 1996;271(6 Pt 1):E1083-91.

26. Dangin M, Guillet C, Garcia-Rodenas C, Gachon P, Bouteloup-Demange C, Reiffers-Magnani K, Fauquant J, Ballevre $\mathrm{O}$, Beaufrere $\mathrm{B}$. The rate of protein digestion affects protein gain differently during aging in humans. J Physiol 2003;549(Pt 2):635-44. 
27. Rutherfurd SM, Fanning AC, Miller BJ, Moughan PJ. Protein digestibility-corrected amino acid scores and digestible indispensable amino acid scores differentially describe protein quality in growing male rats. J Nutr 2015;145(2):372-9.

28. Boirie $Y$, Dangin M, Gachon P, Vasson MP, Maubois JL, Beaufrere B. Slow and fast dietary proteins differently modulate postprandial protein accretion. Proc Natl Acad Sci U S A 1997;94(26):14930-5.

29. Dangin M, Boirie Y, Garcia-Rodenas C, Gachon P, Fauquant J, Callier P, Ballevre O, Beaufrere B. The digestion rate of protein is an independent regulating factor of postprandial protein retention. Am J Physiol Endocrinol Metab 2001;280(2):E340-8.

30. Sarwar Gilani G, Tomé D, Moughan PJ, Rutherfurd SM, Burlingame B. Report of a Sub-Committee of the 2011 FAO Consultation on "Protein Quality Evaluation in Human Nutrition" on: The assessment of amino acid digestibility in foods for humans and including a collation of published ileal amino acid digestibility data for human foods. 2012.

31. Rutherfurd SM, Moughan PJ. Available versus digestible dietary amino acids. The British journal of nutrition 2012;108 Suppl 2:S298-305.

32. Burd NA, Yang Y, Moore DR, Tang JE, Tarnopolsky MA, Phillips SM. Greater stimulation of myofibrillar protein synthesis with ingestion of whey protein isolate $\mathrm{v}$. micellar casein at rest and after resistance exercise in elderly men. The British journal of nutrition 2012;108(6):958-62.

33. Devries MC, Phillips SM. Supplemental protein in support of muscle mass and health: advantage whey. Journal of food science 2015;80 Suppl 1:A8-A15.

34. Calbet JA, MacLean DA. Role of caloric content on gastric emptying in humans. J Physiol 1997;498 ( Pt 2):553-9.

35. Reidy PT, Walker DK, Dickinson JM, Gundermann DM, Drummond MJ, Timmerman KL, Cope MB, Mukherjea R, Jennings $\mathrm{K}$, Volpi $\mathrm{E}$, et al. Soy-dairy protein blend and whey protein ingestion after resistance exercise increases amino acid transport and transporter expression in human skeletal muscle. Journal of applied physiology (Bethesda, Md : 1985) 2014;116(11):1353-64.

36. Reidy PT, Walker DK, Dickinson JM, Gundermann DM, Drummond MJ, Timmerman KL, Fry CS, Borack MS, Cope $M B$, Mukherjea $R$, et al. Protein blend ingestion following resistance exercise promotes human muscle protein synthesis. J Nutr 2013;143(4):410-6. 


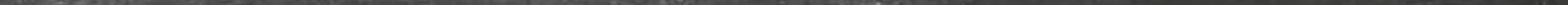




\section{ABSTRACT}

BACKGROUND: Muscle mass maintenance is largely regulated by basal muscle protein synthesis rates and the ability to increase muscle protein synthesis rates after protein ingestion. No studies have evaluated the impact of habituation to either a low or high protein intake on basal and postprandial muscle protein synthesis rates.

OBJECTIVE: To assess the impact of a low versus high protein intake on basal muscle protein synthesis rates and the postprandial muscle protein synthetic response to the ingestion of $25 \mathrm{~g}$ whey protein.

DESIGN: Twenty-four healthy older males (age: $62 \pm 1 \mathrm{y}, \mathrm{BMI}: 25.9 \pm 0.4 \mathrm{~kg} \cdot \mathrm{m}^{-2}$ ) participated in this parallel group randomized trial in which they adapted to either a low $\left(0.7 \mathrm{~g} \cdot \mathrm{kg}^{-1} \cdot \mathrm{d}^{-1}, n=12\right)$ or high $\left(1.5 \mathrm{~g} \cdot \mathrm{kg}^{-1} \cdot \mathrm{d}^{-1}, n=12\right)$ protein diet for 14 days. On day 15 , participants received primed continuous L[ring- $\left.{ }^{2} \mathrm{H}_{5}\right]$-phenylalanine and $\mathrm{L}-\left[1-{ }^{13} \mathrm{C}\right]$-leucine infusions and ingested $25 \mathrm{~g}$ intrinsically $\mathrm{L}-\left[1-{ }^{13} \mathrm{C}\right]-$ phenylalanine and L-[1-13 C]-leucine-labeled whey protein. Muscle biopsies and blood samples were collected to assess basal and postprandial muscle protein synthesis rates as well as dietary protein digestion and absorption kinetics.

RESULTS: Plasma leucine concentrations and exogenous phenylalanine appearance rates increased after protein ingestion $(P<0.01)$, with no differences between treatments $(P>0.05)$. Exogenous plasma phenylalanine availability over the $5 \mathrm{~h}$ postprandial period was greater after the low compared to high protein intake $(61 \pm 1$ vs $56 \pm 2 \%$, respectively; $\mathrm{P}<0.05)$. Muscle protein synthesis rates increased from $0.031 \pm 0.004$ vs $0.039 \pm 0.007 \% \cdot \mathrm{h}^{-1}$ in the fasted state to $0.062 \pm 0.005$ vs $0.057 \pm 0.005 \% \cdot h^{-1}$ in the postprandial state after the low vs high protein intake, respectively $(P<0.01)$, with no apparent differences between treatments $(P=0.25)$.

CONCLUSION: Habituation to a low $\left(0.7 \mathrm{~g} \cdot \mathrm{kg}^{-1} \cdot \mathrm{d}^{-1}\right)$ compared with high $\left(1.5 \mathrm{~g} \cdot \mathrm{kg}^{-1} \cdot \mathrm{d}^{-1}\right)$ protein intake augments the postprandial availability of dietary protein-derived amino acids in the circulation, and does not lower basal muscle protein synthesis rates or increase the postprandial muscle protein synthetic response to protein ingestion in older males. 


\section{INTRODUCTION}

Preservation of skeletal muscle mass is of great importance for maintaining both metabolic health and functional capacity. Muscle mass maintenance is largely regulated by basal muscle protein synthesis rates and the ability to increase muscle protein synthesis rates after protein ingestion (1). The postprandial muscle protein synthetic response to protein ingestion is regulated on various levels (2), including dietary protein digestion and amino acid absorption (3-7), splanchnic retention of dietary protein-derived amino acids $(8,9)$, plasma amino acid availability $(10)$, skeletal muscle perfusion and the subsequent delivery of amino acids to the muscle $(11,12)$, uptake of amino acids by the muscle $(13,14)$, and intramuscular signaling $(15,16)$. Recently, we demonstrated that the ingestion of a single meal-like amount of casein allows $\sim 55 \%$ of the dietary protein-derived amino acids to become available in the circulation during a $5 \mathrm{~h}$ postprandial period (17). Dietary protein-derived amino acids are subsequently taken up by skeletal muscle tissue, thereby improving net protein balance and increasing myofibrillar protein synthesis rates above basal, post-absorptive values. After the ingestion of $20 \mathrm{~g}$ casein, more than $10 \%$ of the dietary protein-derived amino acids are being incorporated into de novo muscle protein within a 5 h postprandial period (17).

Combining the available evidence with these recent observations (17) provides us with a complete and comprehensive insight into postprandial protein handling and the subsequent metabolic fate of dietary protein-derived amino acids after the ingestion of a single meal-like bolus of protein. Despite the clear picture that has emerged of the acute handling of a single protein containing meal, no studies have addressed whether this process is modulated by a person's habitual level of protein consumption. Houston et al. (18) observed that habitual protein intake is associated with muscle mass maintenance. In line, it has been shown that twice daily protein supplementation, thereby increasing habitual protein intake, improves muscle mass (19) or lean body mass (20) in older individuals. Conversely, some studies observed no substantial changes in body composition after large increases or decreases in daily protein consumption $(21,22)$. This suggests that basal and/or postprandial muscle protein synthesis rates adapt to the amount of protein regularly consumed in the diet; a concept commonly referred to as the "adaptive metabolic demand model" for protein requirements (23). Therefore, we hypothesized that postprandial protein handling is modified by habituation to a low versus a high protein intake, with less dietary protein-derived amino acids being retained in the splanchnic tissues and skeletal muscle tissue becoming more sensitive to the postprandial rise in circulating amino acids after habituation to a low versus a high protein intake.

In the present study we investigate the impact of habituation to a low versus a high protein intake on basal muscle protein synthesis rates, dietary protein digestion and amino acid absorption kinetics, and the postprandial muscle protein synthetic response to the ingestion of a single, meallike amount of protein. By applying intravenous infusions of $\mathrm{L}$-[ring $\left.{ }^{2} \mathrm{H}_{5}\right]$-phenylalanine and L-[1$\left.{ }^{13} \mathrm{C}\right]$-leucine combined with the ingestion of intrinsically $\mathrm{L}-\left[1-{ }^{13} \mathrm{C}\right]$-phenylalanine and $\mathrm{L}-\left[1-{ }^{13} \mathrm{C}\right]-$ leucine-labeled protein, we are able to assess dietary protein digestion and absorption kinetics, splanchnic amino acid retention, postprandial muscle protein synthesis rates, and the incorporation of dietary protein-derived amino acids into de novo synthesized muscle protein after two weeks of habituation to a low or a high protein intake (24). This is the first study to evaluate the effect of habituation to a low versus a high protein intake on post-absorptive muscle protein synthesis rates, dietary protein digestion and absorption kinetics, and the subsequent postprandial muscle protein synthetic response to the ingestion of $25 \mathrm{~g}$ whey protein in vivo in humans. 


\section{METHODS}

\section{PARTICIPANTS}

Twenty-four healthy older males (age: $62 \pm 1 \mathrm{y}, \mathrm{BMl}: 25.9 \pm 0.4 \mathrm{~kg} \cdot \mathrm{m}^{-2}$ ) participated in this parallel group randomized trial. The trial was conducted between January 2014 and July 2014 at Maastricht University in Maastricht, the Netherlands. Participants' characteristics are presented in Table 6.1. All participants were informed about the purpose of the study, the experimental procedures, and all of its possible risks prior to providing written consent to participate. The procedures followed were in accordance with the ethical standards of the medical ethics committee of Maastricht University Medical Center+ on human experimentation and in accordance with the Helsinki Declaration of 1975 as revised in October 2013.

Table 6.1 | Participants' characteristics

\begin{tabular}{|c|c|c|c|}
\hline & $\begin{array}{c}\text { LOW PRO } \\
\left(0.7 \mathrm{~g} \cdot \mathrm{kg}^{-1} \cdot \mathrm{d}^{-1}\right)\end{array}$ & $\begin{array}{c}\text { HIGH PRO } \\
\left(1.5 \mathrm{~g} \cdot \mathrm{kg}^{-1} \cdot \mathrm{d}^{-1}\right)\end{array}$ & $P$ value \\
\hline & $n=12$ & $n=12$ & \\
\hline Age $(y)$ & $61 \pm 2$ & $63 \pm 1$ & 0.35 \\
\hline Weight (kg) & $83.9 \pm 1.8$ & $80.8 \pm 1.9$ & 0.24 \\
\hline $\mathrm{BMI}\left(\mathrm{kg} \cdot \mathrm{m}^{-2}\right)$ & $26.0 \pm 0.5$ & $25.9 \pm 0.6$ & 0.84 \\
\hline Systolic BP (mmHg) & $140 \pm 5$ & $139 \pm 6$ & 0.87 \\
\hline Diastolic BP (mmHg) & $76 \pm 4$ & $77 \pm 2$ & 0.84 \\
\hline Fat (\%) & $24.4 \pm 0.9$ & $24.0 \pm 0.9$ & 0.72 \\
\hline Appendicular lean mass (kg) & $27.3 \pm 0.7$ & $26.0 \pm 0.5$ & 0.13 \\
\hline Lean body mass (kg) & $61.1 \pm 1.3$ & $59.2 \pm 1.2$ & 0.30 \\
\hline Fasting plasma glucose $\left(\mathrm{mmol} \cdot \mathrm{L}^{-1}\right)$ & $5.7 \pm 0.1$ & $5.9 \pm 0.2$ & 0.32 \\
\hline $2 \mathrm{~h}$ plasma glucose $\left(\mathrm{mmol}^{-\mathrm{L}^{-1}}\right)$ & $5.3 \pm 0.6$ & $6.1 \pm 0.6$ & 0.36 \\
\hline $\mathrm{HbA}_{1 \mathrm{c}}(\%)$ & $5.3 \pm 0.1$ & $5.4 \pm 0.1$ & 0.81 \\
\hline $\mathrm{OGIS}\left(\mathrm{mL} \cdot \mathrm{min}^{-1} \cdot \mathrm{m}^{-2}\right)$ & $384 \pm 18$ & $373 \pm 14$ & 0.62 \\
\hline
\end{tabular}

Abbreviations: $\mathrm{HbA}_{1 c}$, glycosylated hemoglobin; OGIS, oral glucose insulin sensitivity. Values are means \pm SEM. Data were analyzed by a Student's two-sample t-Test. No significant differences were observed between groups.

\section{PRETESTING}

Healthy male volunteers between the age of 55 and $75 \mathrm{y}$ and a BMI between 18.5 and $30.0 \mathrm{~kg} \cdot \mathrm{m}^{-2}$ underwent a medical screening to assess their $\mathrm{HbA}_{1 c}$, glucose tolerance (by a $2 \mathrm{~h}$ oral glucose tolerance test (25)), blood pressure, weight, height, and body composition (by Dual-energy X-ray absorptiometry; Discovery A; Hologic, Bedford, MA). The participants were deemed healthy based on their responses to a medical questionnaire and screening results. Afterwards, participants were

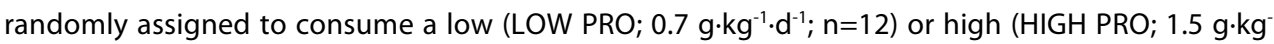
${ }^{1} \cdot d^{-1} ; n=12$ ) protein diet for 14 days prior to the infusion trial. Randomization was performed using a computerized random number generator.

\section{DIETARY INTERVENTION}

Participants' habitual energy intake was calculated from a 3-d dietary record and estimated by the Harris-Benedict equation with a physical activity level of 1.5. The days of recording included two weekdays and one weekend day. Energy and macronutrient intake was calculated using the Dutch 
Nutrients Database (NEVO-online version 2013/4.0). Menus of the dietary intervention were designed for every individual based on their habitual energy intake to ensure body weight maintenance and provided either 0.7 or $1.5 \mathrm{~g} \cdot \mathrm{kg}^{-1} \cdot \mathrm{d}^{-1}$. All food products were provided by the university personnel and were weighed for each participant individually. Participants in the LOW PRO group consumed $12.8 \pm 0.6 \mathrm{~g}, 17.9 \pm 0.8 \mathrm{~g}, 24.9 \pm 0.3 \mathrm{~g}$, and $3.1 \pm 0.3 \mathrm{~g}$ protein and participants in the HIGH PRO group consumed $40.9 \pm 0.8 \mathrm{~g}, 32.5 \pm 1.6 \mathrm{~g}, 37.5 \pm 0.6 \mathrm{~g}$, and $12.4 \pm 1.1 \mathrm{~g}$ protein with breakfast, lunch, dinner, and snacks, respectively. Three days a week at 06:00 PM participants came to the university to consume their dinner. Dietitians supervised during meal time to ensure that the complete meal was consumed. The rest of the meals (i.e., breakfast, lunch, snacks, beverages, and dinner for the remaining days) were provided in take-home packages together with the meal planning and instructions of how to prepare the meals. Compliance was assured via regular contact with the investigators and dietitians (at least three times per week). Nutritional intake during the dietary intervention is reported in Table 6.2. During the last $2 \mathrm{~d}$ of the dietary intervention (i.e. $2 \mathrm{~d}$ prior to the infusion trial) participants were instructed to refrain from any sort of strenuous physical activity.

Table 6.2 | Dietary intake

\begin{tabular}{|c|c|c|c|}
\hline & \multirow{2}{*}{ Habitual intake } & \multicolumn{2}{|c|}{ Dietary intervention } \\
\hline & & LOW PRO & HIGH PRO \\
\hline Energy $\left(\mathrm{MJ} \mathrm{d}^{-1}\right)$ & $9.6 \pm 0.8$ & $10.9 \pm 0.3$ & $10.5 \pm 0.2$ \\
\hline Carbohydrate (En\%) & $49 \pm 2$ & $71 \pm 1$ & $49 \pm 1 \#$ \\
\hline Fat (En\%) & $35 \pm 1$ & $19 \pm 1$ & $31 \pm 0 \#$ \\
\hline Protein (En\%) & $16 \pm 1$ & $9 \pm 0$ & $20 \pm 0 \#$ \\
\hline Protein $\left(\mathrm{g} \cdot \mathrm{kg}^{-1} \cdot \mathrm{d}^{-1}\right)$ & $1.04 \pm 0.08$ & $0.70 \pm 0.00$ & $1.53 \pm 0.01 \#$ \\
\hline
\end{tabular}

Values are means \pm SEM. Data were analyzed by a Student's two-sample t-Test. \# Significantly different from LOW PRO.

\section{INFUSION PROTOCOL}

At 08:00 AM, after an overnight fast, participants arrived at the laboratory by car or public transport. A catheter was inserted into an antecubital vein for stable isotope amino acid infusion. A second catheter was inserted into a dorsal hand vein of the contralateral arm and placed in a hotbox $\left(60^{\circ} \mathrm{C}\right)$ for arterialized blood sampling (26). After taking a baseline blood sample, the plasma phenylalanine, tyrosine, and leucine pools were primed with a single dose of $\mathrm{L}-\left[\mathrm{ring}_{-}{ }^{2} \mathrm{H}_{5}\right]-$ phenylalanine $\left(2.2 \mu \mathrm{mol} \cdot \mathrm{kg}^{-1}\right)$, L-[ring-3,5- $\left.{ }^{2} \mathrm{H}_{2}\right]$-tyrosine $\left(0.7 \mu \mathrm{mol} \cdot \mathrm{kg}^{-1}\right)$, and L-[1- $\left.{ }^{13} \mathrm{C}\right]$-leucine $(4.4$ $\left.\mu \mathrm{mol} \cdot \mathrm{kg}^{-1}\right)$, after which a continuous $\mathrm{L}-\left[\mathrm{ring}^{2}{ }^{2} \mathrm{H}_{5}\right]$-phenylalanine $\left(0.055 \mu \mathrm{mol} \cdot \mathrm{kg}^{-1} \cdot \mathrm{min}^{-1}\right), \mathrm{L}-[\mathrm{ring}-3,5-$ $\left.{ }^{2} \mathrm{H}_{2}\right]$-tyrosine $\left(0.017 \mu \mathrm{mol} \cdot \mathrm{kg}^{-1} \cdot \mathrm{min}^{-1}\right)$, and $\mathrm{L}-\left[1{ }^{13} \mathrm{C}\right]$-leucine $\left(0.110 \mu \mathrm{mol} \cdot \mathrm{kg}^{-1} \cdot \mathrm{min}^{-1}\right)$ intravenous infusion was initiated ( $\mathrm{t}=-210 \mathrm{~min}$ ). After resting in a supine position for $90 \mathrm{~min}$, a second arterialized blood sample was drawn and a muscle biopsy was collected from the vastus lateralis from a randomized leg ( $\mathrm{t}=-120 \mathrm{~min}$ ). To determine basal muscle protein synthesis rates, a second muscle biopsy from the same leg was collected $120 \mathrm{~min}$ after the first biopsy. Subsequently, participants received a beverage containing $25 \mathrm{~g}$ intrinsically $\mathrm{L}-\left[1-{ }^{13} \mathrm{C}\right]$-phenylalanine and $\mathrm{L}-\left[1-{ }^{13} \mathrm{C}\right]-$ leucine-labeled whey protein ( $\mathrm{t}=0 \mathrm{~min}$ ). Arterialized blood samples were collected at $\mathrm{t}=-90,-60$, $30,0,15,30,45,60,75,90,120,150,180,210,240,270$, and $300 \mathrm{~min}$. A third and fourth muscle biopsy was collected from the contralateral leg at $t=120$ and $t=300 \mathrm{~min}$, respectively, to determine postprandial muscle protein synthesis rates. Blood samples were collected in EDTA containing tubes and centrifuged at $1000 \mathrm{~g}$ for $10 \mathrm{~min}$ at $4^{\circ} \mathrm{C}$. Aliquots of plasma were frozen in liquid nitrogen and stored at $-80^{\circ} \mathrm{C}$. Biopsies were collected from the middle region of the vastus lateralis, 
approximately $15 \mathrm{~cm}$ above the patella and $3 \mathrm{~cm}$ below entry through the fascia, using the percutaneous needle biopsy technique (27). Muscle samples were dissected carefully, freed from any visible non-muscle material, immediately frozen in liquid nitrogen, and stored at $-80^{\circ} \mathrm{C}$ until further analysis. For a schematic representation of the infusion protocol please see Figure 6.1.

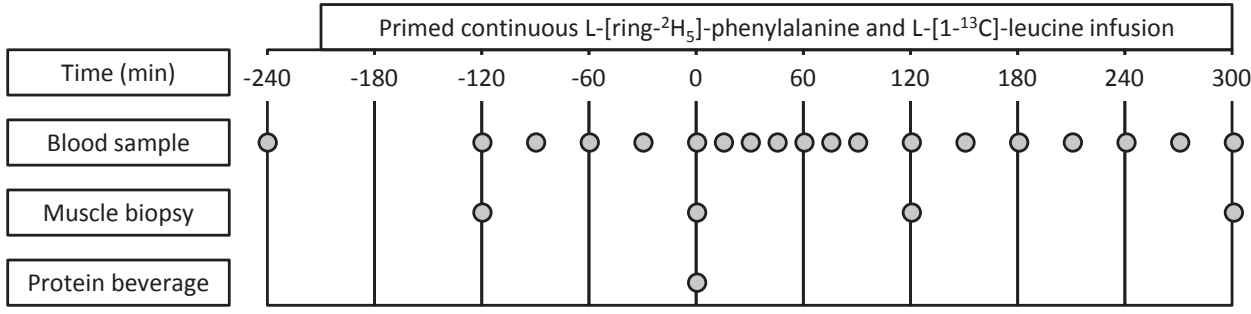

Figure 6.1 | Schematic representation of the infusion protocol

\section{PREPARATION OF INTRINSICALLY LABELED PROTEIN AND BEVERAGE COMPOSITION}

Intrinsically $\mathrm{L}-\left[1-{ }^{13} \mathrm{C}\right]$-phenylalanine and $\mathrm{L}-\left[1-{ }^{13} \mathrm{C}\right]$-leucine-labeled whey protein was prepared by infusing $\mathrm{L}-\left[1-{ }^{13} \mathrm{C}\right]$-phenylalanine and $\mathrm{L}-\left[1-{ }^{13} \mathrm{C}\right]$-leucine into a lactating Holstein cow, collecting milk, and purifying the whey fraction as described previously $(28-30)$. The $\mathrm{L}-\left[1-{ }^{13} \mathrm{C}\right]$-phenylalanine and $\mathrm{L}-$ $\left[1-{ }^{13} \mathrm{C}\right]$-leucine enrichments of the whey protein were 36.1 and 8.9 mole percent excess (MPE), respectively. The whey protein met all chemical and bacteriologic specifications required for human consumption. Participants received a beverage containing $25 \mathrm{~g}$ whey protein (containing $2.47 \mathrm{~g}$ leucine) in a total volume of $250 \mathrm{~mL}$.

\section{PLASMA ANALYSES}

Plasma glucose and insulin concentrations were analyzed using commercially available kits (Glucose HK Gen.3, Roche, Ref: 05168791190, and Elecsys Insulin assay, Roche, Ref: 12017547122, respectively). Plasma amino acid concentrations and enrichments were determined by gas chromatography-mass spectrometry (GC-MS; Agilent 7890A GC/5975C; MSD, Wilmington, Delaware, USA). Specifically, the internal standards $\left[\mathrm{U}-{ }^{13} \mathrm{C}_{6}\right]$-leucine, $\left[\mathrm{U}-{ }^{13} \mathrm{C}_{9}{ }^{15} \mathrm{~N}\right]$-phenylalanine, and $\left[\mathrm{U}-{ }^{13} \mathrm{C}_{9}{ }^{15} \mathrm{~N}\right]$-tyrosine were added to the plasma sample. The plasma was deproteinized with 5sulfosalicylic acid. Free amino acids were purified using cation exchange AG 50W-X8 resin (mesh size: 100-200, ionic form: hydrogen (Bio-Rad Laboratories, Hercules, California, USA)) columns. The purified amino acids were converted into tert-butyldimethylsilyl (tert-BDMS) derivatives with MTBSTFA before analysis by GC-MS. The amino acid concentrations were determined using electron impact ionization by monitoring ions at mass/charge $(\mathrm{m} / \mathrm{z}) 302$ and 308 for unlabeled and $\left[\mathrm{U}-{ }^{13} \mathrm{C}_{6}\right]$-leucine, 336 and 346 for unlabeled and $\left[\mathrm{U}^{13} \mathrm{C}_{9}{ }^{15} \mathrm{~N}\right]$-phenylalanine, and 466 and 476 for unlabeled and $\left[\mathrm{U}-{ }^{13} \mathrm{C}_{9}{ }^{15} \mathrm{~N}\right]$-tyrosine, respectively. The plasma leucine, phenylalanine, and tyrosine ${ }^{13} \mathrm{C}$ and ${ }^{2} \mathrm{H}$ enrichments were determined using selective ion monitoring at $\mathrm{m} / \mathrm{z} 302$ and 303 for unlabeled and labeled $\left(1-{ }^{13} \mathrm{C}\right)$ leucine, respectively; $\mathrm{m} / \mathrm{z} 336,337$, and 341 for unlabeled and labeled $\left(1-{ }^{13} \mathrm{C}\right.$ and ring $\left.-{ }^{2} \mathrm{H}_{5}\right)$ phenylalanine, respectively; $\mathrm{m} / \mathrm{z} 466,467,468$, and 470 for unlabeled and labeled $\left(1-{ }^{13} \mathrm{C}\right.$, ring $-3,5-{ }^{2} \mathrm{H}_{2}$, and ring $\left.-{ }^{2} \mathrm{H}_{4}\right)$ tyrosine, respectively. Standard regression curves from a series of known standard enrichment values against the measured enrichment values were applied to assess linearity of the mass spectrometer and to account for isotopic fractionation.

MUSCLE ANALYSES

Myofibrillar proteins were extracted from $\sim 60 \mathrm{mg}$ of wet muscle by hand-homogenizing in 7 $\mu \mathrm{L} \cdot \mathrm{mg}^{-1}$ homogenization buffer using a Teflon pestle. Samples were centrifuged at $2,500 \mathrm{~g}$ for 5 


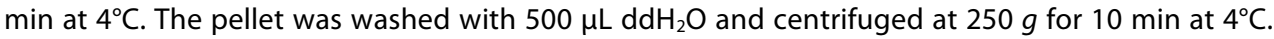
The myofibrillar proteins in the pellet were solubilized by adding $1 \mathrm{~mL}$ of $0.3 \mathrm{M} \mathrm{NaOH}$ and heating at $50^{\circ} \mathrm{C}$ for $30 \mathrm{~min}$ with vortex mixing every $10 \mathrm{~min}$. Samples were centrifuged at $12,000 \mathrm{~g}$ for $5 \mathrm{~min}$ at $4^{\circ} \mathrm{C}$. The supernatant containing the myofibrillar proteins was collected and the collagen pellet was discarded. Myofibrillar proteins were precipitated by adding $1 \mathrm{~mL}$ of $1 \mathrm{M} \mathrm{PCA}$ and centrifuging at $1,000 \mathrm{~g}$ for $10 \mathrm{~min}$ at $4^{\circ} \mathrm{C}$. The myofibrillar protein pellet was washed twice with $1 \mathrm{~mL}$ of $70 \%$ ethanol and hydrolyzed overnight in $2 \mathrm{~mL}$ of $6 \mathrm{M} \mathrm{HCl}$ at $110^{\circ} \mathrm{C}$. The free amino acids from the hydrolyzed myofibrillar protein pellet were dried under nitrogen stream while being heated to $120^{\circ} \mathrm{C}$. The free amino acids were then dissolved in $25 \%$ acetic acid solution, passed over cation exchange AG 50W-X8 resin columns (mesh size: 100-200, ionic form: hydrogen (Bio-Rad Laboratories, Hercules, California, USA)), and eluted with $2 \mathrm{M} \mathrm{NH}_{4} \mathrm{OH}$. The purified amino acids were divided into 2 aliquots to determine the L-[ring- ${ }^{2} \mathrm{H}_{5}$ ]-phenylalanine enrichments by GC-MS analysis and the $\mathrm{L}-\left[1-{ }^{13} \mathrm{C}\right]$-phenylalanine and $\mathrm{L}-\left[1-{ }^{13} \mathrm{C}\right]$-leucine enrichments by gas chromatography-combustion-isotope ratio mass spectrometry (GC-C-IRMS) analysis.

To reduce the signal-to-noise ratio during GC-MS analysis at low tracer enrichments, the phenylalanine from the myofibrillar protein hydrolysates was enzymatically decarboxylated to $\beta$ phenylethylamine prior to derivatization with MTBSTFA. To determine myofibrillar protein L-[1$\left.{ }^{13} \mathrm{C}\right]$-phenylalanine and L-[1-13 $\left.\mathrm{C}\right]$-leucine enrichments by GC-C-IRMS analysis, the purified amino acids were converted into N-ethoxycarbonyl ethyl ester derivatives with ethyl chloroformate (ECF). The derivatives were then measured by GC-C-IRMS (Finnigan MAT 253, Bremen, Germany) using a DB5-MS-column (no. 122-5532; Agilent J+W scientific GC Column), GC Isolink, and monitoring of ion masses 44,45 and 46 . Standard regression curves were applied to assess the linearity of the mass spectrometer and to account for isotopic fractionation.

\section{Calculations}

Ingestion of $\mathrm{L}-\left[1-{ }^{13} \mathrm{C}\right]$-phenylalanine-labeled protein, intravenous infusion of $\mathrm{L}$-[ring- $\left.{ }^{2} \mathrm{H}_{5}\right]$ phenylalanine and L-[ring-3,5- ${ }^{2} \mathrm{H}_{2}$ ]-tyrosine, and arterialized blood sampling were used to assess whole-body amino acid kinetics in non-steady state conditions. Total, exogenous, and endogenous rate of appearance $\left(R_{a}\right)$ and plasma availability of dietary protein-derived phenylalanine (i.e., the fraction of dietary protein-derived phenylalanine that appeared in the

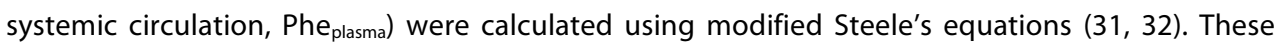
parameters were calculated as follows:

Total $R_{a}=\frac{F_{i v}-\left[p V \times C(t) \times \frac{d E_{i v}}{d t}\right]}{E_{i v}(t)}$
Exo $R_{a}=\frac{\text { Total } R_{a} \times E_{p o}(t)+\left[p V \times C(t) \times \frac{d E_{p o}}{d t}\right]}{E_{\text {prot }}}$

Endo $R_{a}=$ Total $R_{a}-$ Exo $R_{a}-F_{i v}$

Phe $e_{\text {plasma }}=\left(\frac{A U C_{\text {Exo Ra }}}{\text { Phe }_{\text {prot }}}\right) \times B W \times 100 \%$

where $F_{i v}$ is the intravenous tracer infusion rate $\left(\mu \mathrm{mol} \cdot \mathrm{kg}^{-1} \cdot \mathrm{min}^{-1}\right) ; p V\left(0.125 \mathrm{~L} \cdot \mathrm{kg}^{-1}\right)$ is the distribution volume (31); $C(t)$ is the mean plasma phenylalanine concentration between two consecutive time points; $d E_{i v} / d t$ is the time-dependent variation in plasma phenylalanine enrichment derived from the intravenous tracer; and $E_{i v}(t)$ is the mean plasma phenylalanine enrichment derived from the 
intravenous tracer between two consecutive time points. Exo $R_{a}$ represents the rate at which dietary protein-derived phenylalanine enters the circulation. $E_{p o}(t)$ is the mean plasma phenylalanine enrichment derived from the oral tracer between two consecutive time points; $d E_{p o} / d t$ is the time-dependent variation in plasma phenylalanine enrichment derived from the oral tracer; and $E_{\text {prot }}$ is the $\mathrm{L}-\left[1-{ }^{13} \mathrm{C}\right]$-phenylalanine enrichment of the dietary protein. $A \cup C_{\text {Exo Ra }}$ represents the area under the curve (AUC) of Exo $R_{a}$, which corresponds to the amount of dietary proteinderived phenylalanine that appeared in the circulation over the 5-h postprandial period; Phe $_{\text {prot }}$ is the amount of dietary phenylalanine ingested; and $B W$ is the participants' body weight.

Total phenylalanine rate of disappearance $\left(R_{d}\right)$ represents the rate of phenylalanine hydroxylation (first step in phenylalanine oxidation) plus the rate of phenylalanine utilization for protein synthesis. This parameter is calculated as follows:

Total $R_{d}=$ Total $R_{a}-p V \times \frac{d C}{d t}$

Phe hydroxylation $=$ Tyr $R_{a} \times \frac{E_{\text {Tyr }}(t)}{E_{P h e}(t)} \times \frac{\text { Phe } R_{d}}{\left(F_{P h e}+P h e R_{d}\right)}$

Protein synthesis $=$ Total $R_{d}-$ Phe hydroxylation

Phe net balance $=$ Protein synthesis - Endo $R_{a}$

where $d C / d t$ is the time-dependent variation in plasma phenylalanine concentrations. Tyr $R_{a}$ is the total rate of tyrosine appearance based on the L-[ring-3, $5-{ }^{2} \mathrm{H}_{2}$ ]-tyrosine infusion and plasma enrichments. $E_{\text {Tyr }}(t)$ and $E_{\text {Phe }}(t)$ represent the mean plasma L-[ring- $\left.{ }^{2} \mathrm{H}_{4}\right]$-tyrosine and L-[ring- $\left.{ }^{2} \mathrm{H}_{5}\right]-$ phenylalanine enrichment between 2 consecutive time points, respectively, Phe $R_{d}$ is the total phenylalanine rate of disappearance, and $F_{\text {Phe }}$ is the intravenous infusion rate of L-[ring- $\left.{ }^{2} \mathrm{H}_{5}\right]-$ phenylalanine $\left(\mu \mathrm{mol} \cdot \mathrm{kg}^{-1} \cdot \mathrm{min}^{-1}\right)$.

Myofibrillar protein fractional synthetic rates (FSR) were calculated using the standard precursorproduct equation:

$F S R=\frac{\Delta E_{p}}{E_{\text {precursor }} \cdot t} \cdot 100 \%$

where $\Delta E_{p}$ is the increment in myofibrillar protein-bound $\mathrm{L}-\left[1-{ }^{13} \mathrm{C}\right]$-leucine or $\mathrm{L}$-[ring $\left.-{ }^{2} \mathrm{H}_{5}\right]-$ phenylalanine enrichment after an incorporation period (tracer-to-tracee ratio, TTR), $E_{\text {precursor }}$ is the weighted mean plasma L-[1-13 $\mathrm{C}]$-leucine or L-[ring- $\left.{ }^{2} \mathrm{H}_{5}\right]$-phenylalanine enrichment during that incorporation period (TTR), and $t$ is the incorporation period (h). For basal FSR, muscle biopsies at $\mathrm{t}=-120$ and 0 min were used, and for postprandial FSR, biopsies at $\mathrm{t}=0,120$, and $300 \mathrm{~min}$ were used for the calculation.

\section{STATISTICS}

All data are expressed as mean \pm SEM. Incremental area under curve (iAUC), peak value, and time to peak were calculated for all plasma time curves and Student's t-tests were applied to identify differences between treatments. For plasma and muscle time curves, a repeated measures ANOVA with treatment, time, and their interaction was used to identify differences between treatments over time. Statistical significance was set at $\mathrm{P}<0.05$. All calculations were performed using IBM SPSS Statistics (version 21). 


\section{RESULTS}

\section{PLASMA METABOLITES}

Plasma insulin concentrations increased after protein intake in both groups $(P<0.001)$, with no differences between treatments (TimexTreatment $P=0.843$; Figure 6.2). Peak insulin concentrations averaged $36 \pm 6$ and $35 \pm 5 \mathrm{mU} \cdot \mathrm{L}^{-1}$ in the LOW PRO and HIGH PRO group, respectively $(P=0.910)$. Plasma phenylalanine and leucine concentrations rapidly increased after the ingestion of $25 \mathrm{~g}$ whey protein (both $\mathrm{P}<0.001$ ), and did not differ between treatments (TimexTreatment $\mathrm{P}=0.302$ and $\mathrm{P}=0.668$, respectively; Figure 6.3). Peak leucine averaged $568 \pm 21$ and $558 \pm 20 \mu \mathrm{mol} \cdot \mathrm{L}^{-1}$ in the LOW PRO and HIGH PRO group, respectively $(P=0.740)$.

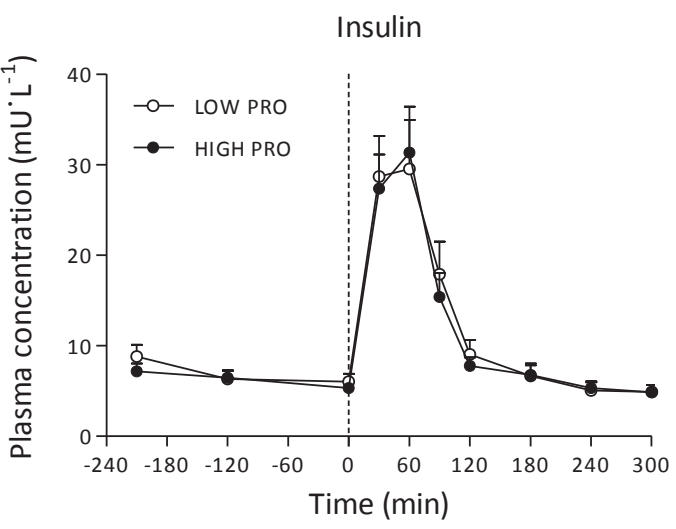

Figure 6.2 Mean ( \pm SEM) plasma insulin concentrations $\left(\mathrm{mU}^{\left.-\mathrm{L}^{-1}\right)}\right.$ during the fasted state and after the ingestion of $25 \mathrm{~g}$ whey protein in healthy older males who consumed a low $\left(0.7 \mathrm{~g} \cdot \mathrm{kg}^{-1} \cdot \mathrm{d}^{-1}, \mathrm{n}=12\right)$ or high $\left(1.5 \mathrm{~g} \cdot \mathrm{kg}^{-1} \cdot \mathrm{d}^{-1}, \mathrm{n}=12\right)$ protein diet for 14 days prior to the infusion trial. Dashed line refers to protein ingestion. Basal: Time $P<0.001$, Treatment $P=0.528$, TimexTreatment $\mathrm{P}=0.187$; Postprandial: Time $\mathrm{P}<0.001$, Treatment $\mathrm{P}=0.867$, TimexTreatment $\mathrm{P}=0.843$, Peak value $\mathrm{P}=0.910$.

A

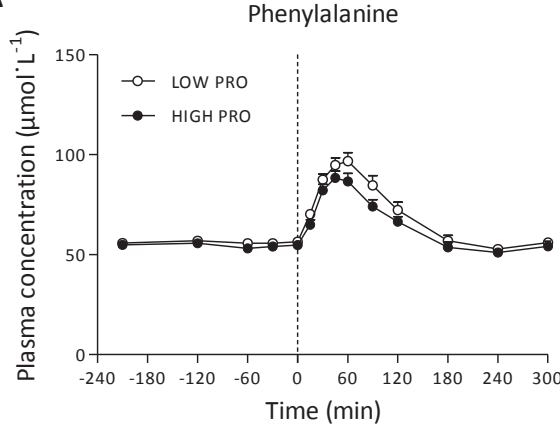

B

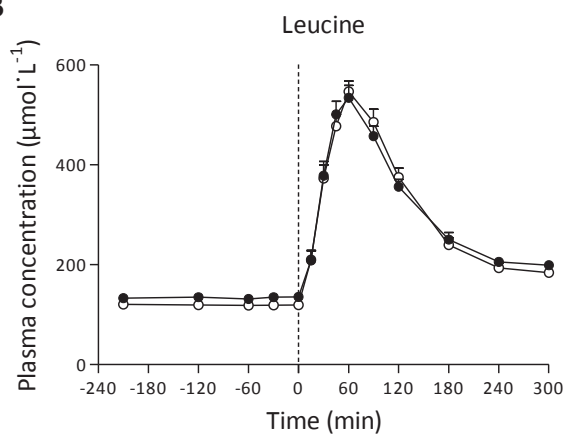

Figure 6.3 Mean ( $\left(\right.$ SEM) plasma phenylalanine $(A)$ and leucine $(B)$ concentrations $\left(\mu \mathrm{mol} \cdot \mathrm{L}^{-1}\right)$ during the fasted state and

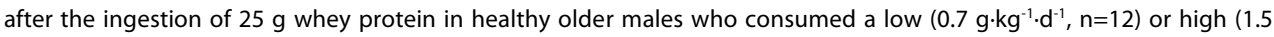
$\mathrm{g} \mathrm{kg}^{-1} \cdot \mathrm{d}^{-1}, \mathrm{n}=12$ ) protein diet for 14 days prior to the infusion trial. Dashed line refers to protein ingestion. A: Basal: Time $P=0.046$, Treatment $P=0.517$, Time $\times$ Treatment $P=0.485$; Postprandial: Time $P<0.001$, Treatment $P=0.124$, TimexTreatment $P=0.302$. B: Basal: Time $p=0.504$, Treatment $P=0.016$, TimexTreatment $P=0.559$; Postprandial: Time $P<0.001$, Treatment $P=0.845$, Time $\times$ Treatment $P=0.668$, Peak value $P=0.740$. 


\section{PLASMA TRACERS}

Plasma L-[ring- $\left.{ }^{2} \mathrm{H}_{5}\right]$-phenylalanine (intravenous tracer), $\mathrm{L}-\left[1-{ }^{13} \mathrm{C}\right]$-phenylalanine (oral tracer), and L$\left[1-{ }^{13} \mathrm{C}\right]$-leucine (intravenous and oral tracer) enrichments are shown in Figure 6.4. Plasma L-[ring${ }^{2} \mathrm{H}_{5}$ ]-phenylalanine enrichments declined after protein ingestion in both groups $(\mathrm{P}<0.001)$, with no differences between treatments (TimexTreatment $\mathrm{P}=0.725$; Figure $6.4 \mathrm{~A}$ ). Plasma $\mathrm{L}-\left[1-{ }^{13} \mathrm{C}\right]$-leucine enrichments remained in steady state throughout the experimental period in both treatment groups (Figure 6.4B). Plasma L-[1- $\left.{ }^{13} \mathrm{C}\right]$-phenylalanine enrichments rapidly increased after protein ingestion $(P<0.001)$, with no differences between treatment groups (TimexTreatment $P=0.777$; Figure 6.4C).

A

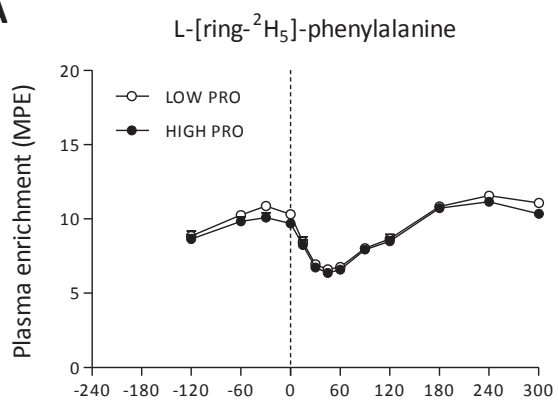

B

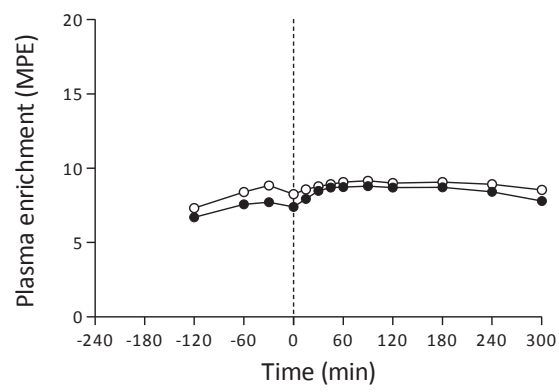

C

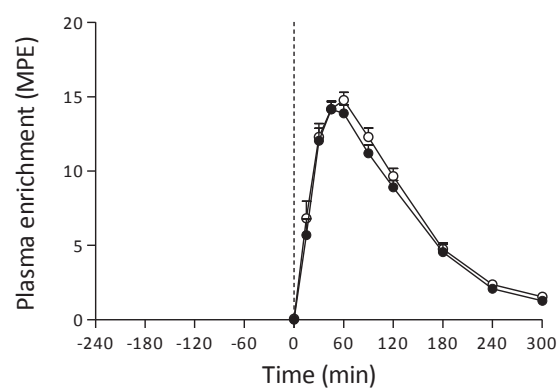

Figure 6.4 Mean ( \pm SEM) plasma L-[ring $\left.-{ }^{2} \mathrm{H}_{5}\right]$-phenylalanine $(\mathrm{A}), \mathrm{L}-\left[1-{ }^{13} \mathrm{C}\right]$-leucine $(\mathrm{B})$, and $\mathrm{L}-\left[1-{ }^{13} \mathrm{C}\right]$-phenylalanine $(\mathrm{C})$ enrichments (mole percent excess, MPE) during the fasted state and after the ingestion of $25 \mathrm{~g}$ whey protein in healthy older males who consumed a low $\left(0.7 \mathrm{~g} \cdot \mathrm{kg}^{-1} \cdot \mathrm{d}^{-1}, \mathrm{n}=12\right)$ or high $\left(1.5 \mathrm{~g} \cdot \mathrm{kg}^{-1} \cdot \mathrm{d}^{-1}, \mathrm{n}=12\right)$ protein diet for 14 days prior to the infusion trial. Dashed line refers to protein ingestion. A: Basal: Time $P<0.001$, Treatment $P=0.185$, TimexTreatment $P=0.251$; Postprandial: Time $P<0.001$, Treatment $P=0.142$, TimexTreatment $P=0.725$. B: Basal: Time $P<0.001$, Treatment $P=0.002$, Time $x$ Treatment $P=0.297$; Postprandial: Time $P<0.001$, Treatment $P<0.001$, TimexTreatment $P=0.008$. C: Postprandial: Time $\mathrm{P}<0.001$, Treatment $\mathrm{P}=0.046$, TimexTreatment $\mathrm{P}=0.777$.

\section{WHOLE-BODY PHENYLALANINE KINETICS AND METABOLISM}

Figure 6.5 shows whole-body phenylalanine kinetics. Exogenous phenylalanine appearance rates (i.e., the rate at which dietary protein-derived phenylalanine enters the circulation) rapidly increased after protein ingestion $(\mathrm{P}<0.001)$, and did not differ between treatments (TimexTreatment $\mathrm{P}=0.876$; Figure $6.5 \mathrm{~A}$ ). The total amount of dietary protein-derived phenylalanine that appeared in the circulation was higher in the LOW PRO when compared with HIGH PRO group over both the early ( $0-2 \mathrm{~h}$ ) and entire (0-5 h) postprandial period ( $47 \pm 1$ vs $43 \pm 1 \%$ and $61 \pm 1$ vs $56 \pm 2 \% ; \mathrm{P}=0.030$ and $\mathrm{P}=0.039$, respectively). As such, $39 \pm 1$ vs $44 \pm 2 \%$ of dietary protein-derived 
amino acids were retained/utilized by the gut in the LOW PRO vs HIGH PRO group, respectively, which was significantly higher in the HIGH PRO when compared with LOW PRO group $(P=0.039$; Figure 6.6). Endogenous phenylalanine appearance rates (i.e., the rate at which phenylalanine derived from whole-body protein breakdown enters the circulation) declined after protein ingestion $(\mathrm{P}<0.001)$, and were lower in the LOW PRO when compared with HIGH PRO group (Treatment $\mathrm{P}=0.033$; Figure $6.5 \mathrm{~B}$ ). Protein ingestion increased total phenylalanine appearance rates $(P<0.001$; Figure 6.5C) and total phenylalanine disappearance rates $(P<0.001$; Figure 6.5D) with no differences between groups (TimexTreatment $\mathrm{P}=0.946$ and $\mathrm{P}=0.624$, respectively).

A

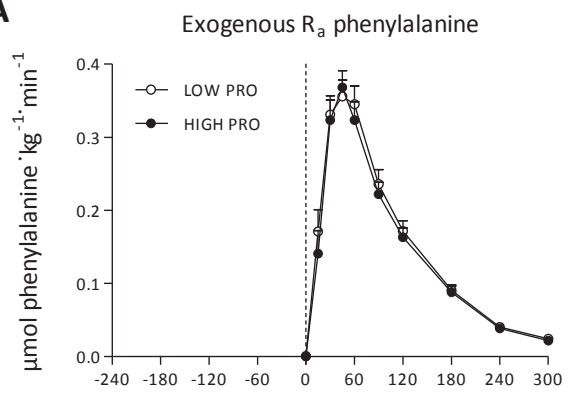

C

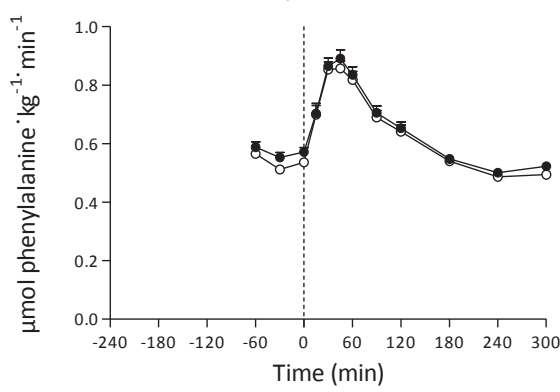

B

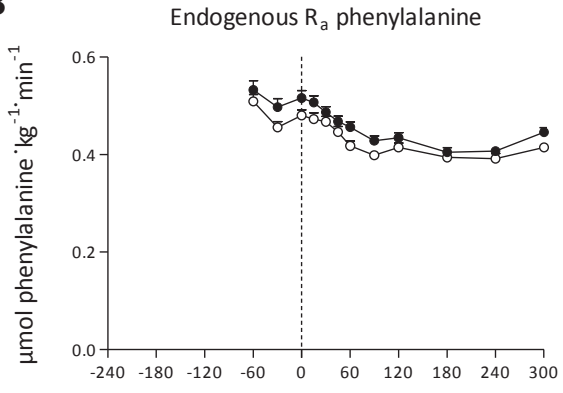

D

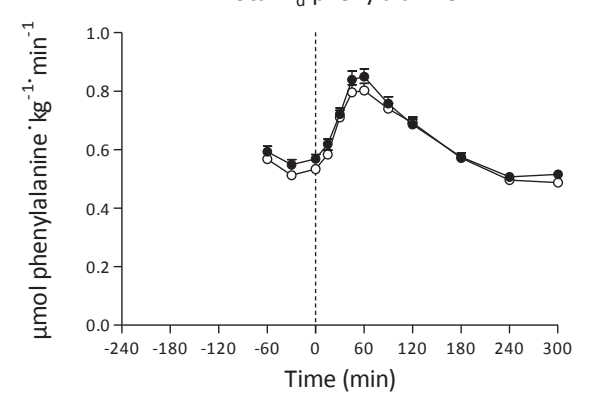

Figure 6.5 | Whole-body phenylalanine kinetics. Mean ( \pm SEM) exogenous rate of appearance $\left(R_{a} ; A\right)$, endogenous $R_{a}(B)$, total $R_{a}(C)$, and total rate of disappearance $\left(R_{d} ; D\right)\left(\mu \mathrm{mol}^{\prime} \mathrm{kg}^{-1} \cdot \mathrm{min}^{-1}\right)$ during the fasted state and after the ingestion of $25 \mathrm{~g}$

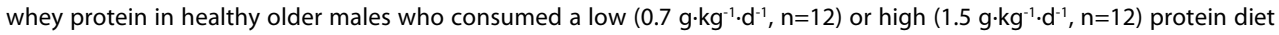
for 14 days prior to the infusion trial. Dashed line refers to protein ingestion. A: Postprandial: Time $P<0.001$, Treatment $\mathrm{P}=0.377$, TimexTreatment $\mathrm{P}=0.876$. B: Basal: Time $\mathrm{P}<0.001$, Treatment $\mathrm{P}=0.103$, Time $\times$ Treatment $\mathrm{P}=0.444$; Postprandial: Time $P<0.001$, Treatment $P=0.033$, TimexTreatment $P=0.511$. C: Basal: Time $P<0.001$, Treatment $P=0.112$, TimexTreatment $\mathrm{P}=0.417$; Postprandial: Time $\mathrm{P}<0.001$, Treatment $\mathrm{P}=0.261$, TimexTreatment $\mathrm{P}=0.946$. $\mathrm{D}$ : Basal: Time $P<0.001$, Treatment $P=0.125$, TimexTreatment $P=0.692 ;$ Postprandial: Time $P<0.001$, Treatment $P=0.156$, TimexTreatment $\mathrm{P}=0.624$. 


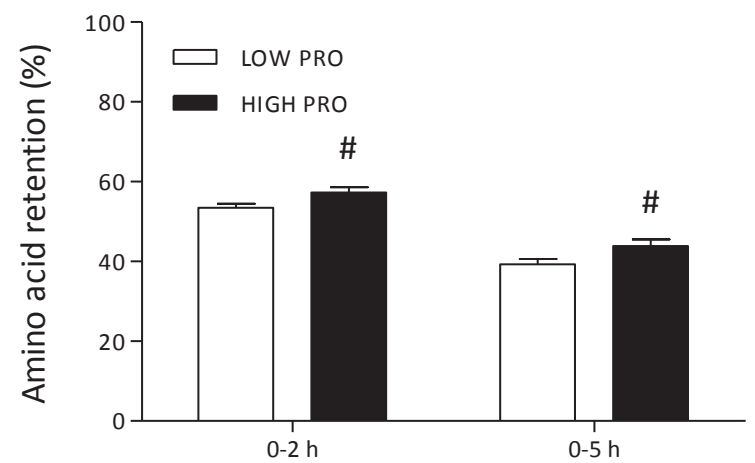

Figure 6.6 | Mean ( \pm SEM) splanchnic amino acid retention (\%) after the ingestion of $25 \mathrm{~g}$ whey protein in healthy older males who consumed a low $\left(0.7 \mathrm{~g} \cdot \mathrm{kg}^{-1} \cdot \mathrm{d}^{-1}, \mathrm{n}=12\right)$ or high $\left(1.5 \mathrm{~g} \cdot \mathrm{kg}^{-1} \cdot \mathrm{d}^{-1}, \mathrm{n}=12\right)$ protein diet for 14 days prior to the infusion trial. 0-2 h: $P=0.030 ; 0-5$ h: $P=0.039$. \# Significantly different from LOW PRO.

Basal and postprandial whole-body protein breakdown, synthesis, oxidation, and net balance are shown in Figure 6.7. Regardless of condition, protein ingestion decreased whole-body protein breakdown rates $(P<0.001)$ and increased whole-body protein synthesis rates $(P<0.001)$, resulting in a more positive whole-body net protein balance when compared with the basal post-absorptive state $(P<0.001)$. Whole-body protein breakdown rates tended to be lower (Treatment $P=0.079$ ) and oxidation rates were lower (Treatment $\mathrm{P}=0.036$ ) in the LOW PRO when compared with HIGH PRO group, whereas whole-body protein synthesis rates did not differ between treatments (Treatment $\mathrm{P}=0.325)$. As a result, whole-body net protein balance tended to be higher in the LOW PRO when compared with HIGH PRO group (Treatment $\mathrm{P}=0.070$ ).

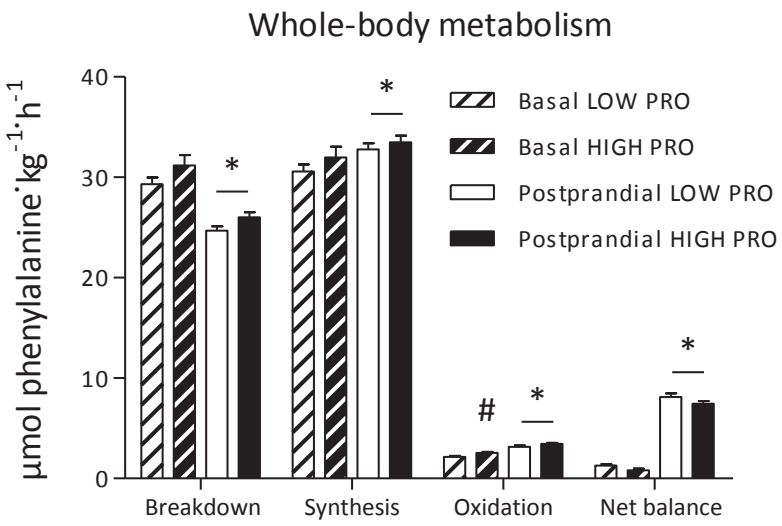

Figure 6.7 | Mean ( \pm SEM) whole-body protein breakdown, synthesis, oxidation, and net balance during the fasted state

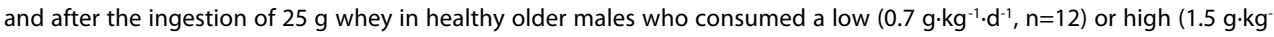
${ }^{1} \cdot d^{-1}, n=12$ ) protein diet for 14 days prior to the infusion trial. Breakdown: Time $P<0.001$, Treatment $P=0.079$, TimexTreatment $P=0.542$. Synthesis: Time $P<0.001$, Treatment $P=0.325$, TimexTreatment $P=0.340$. Oxidation: Time $P<0.001$, Treatment $P=0.036$, TimexTreatment $P=0.393$. Net balance: Time $P<0.001$, Treatment $P=0.070$, Timex Treatment $\mathrm{P}=0.612$. * Significantly different from basal. \# Significantly different from LOW PRO. 


\section{MUSCLE PROTEIN SYNTHESIS}

Myofibrillar protein fractional synthetic rates (FSR) were calculated based on the L-[ring- $\left.{ }^{2} \mathrm{H}_{5}\right]$ phenylalanine (intravenous) and L- $\left[1-{ }^{13} \mathrm{C}\right]$-leucine (intravenous and oral) tracer using the plasma precursor pool (Figure 6.8). Basal myofibrillar protein synthesis rates did not differ between the LOW PRO and HIGH PRO group when calculated based on the L-[ring- ${ }^{2} \mathrm{H}_{5}$ ]-phenylalanine tracer $\left(0.030 \pm 0.001\right.$ vs $0.029 \pm 0.003 \% \cdot h^{-1}$, respectively; $\left.\mathrm{P}=0.753\right)$ or $\mathrm{L}-\left[1-{ }^{13} \mathrm{C}\right]$-leucine tracer $(0.031 \pm 0.004$ vs $0.039 \pm 0.007 \% \cdot h^{-1}$, respectively; $P=0.313$ ). Ingesting $25 \mathrm{~g}$ whey protein significantly increased myofibrillar protein synthesis rates in both the LOW PRO and HIGH PRO group when assessed over the entire $(0-5 \mathrm{~h})$ postprandial period using the $\mathrm{L}$-[ring- ${ }^{2} \mathrm{H}_{5}$ ]-phenylalanine $(0.040 \pm 0.003$ vs $0.035 \pm 0.002 \% \cdot h^{-1}$, respectively) and $\mathrm{L}-\left[1{ }^{-13} \mathrm{C}\right]$-leucine $\left(0.062 \pm 0.005\right.$ vs $0.057 \pm 0.005 \% \cdot \mathrm{h}^{-1}$, respectively) tracer $(\mathrm{P}<0.001)$. $\mathrm{L}-\left[1-{ }^{13} \mathrm{C}\right]$-leucine $\mathrm{FSR}$ also increased from post-absorptive rates when assessed over the early $(0-2 \mathrm{~h})$ postprandial period $\left(0.055 \pm 0.006\right.$ vs $0.049 \pm 0.007 \% \cdot \mathrm{h}^{-1}$ in the LOW PRO vs HIGH PRO group, respectively; $P=0.025)$. The postprandial increase in myofibrillar protein synthesis rates did not differ between the LOW PRO and HIGH PRO treatment $(P>0.1)$. In agreement, myofibrillar protein-bound $\mathrm{L}-\left[1-{ }^{13} \mathrm{C}\right]$-phenylalanine enrichments increased over time, but did not differ between treatments $(0.007 \pm 0.001$ vs $0.007 \pm 0.001$ MPE at $2 \mathrm{~h}$ and $0.016 \pm 0.001$ vs $0.015 \pm 0.001$ at $5 \mathrm{~h}$ after protein ingestion; $\mathrm{P}=0.599$ and $\mathrm{P}=0.526$, respectively; Figure 6.9).

A

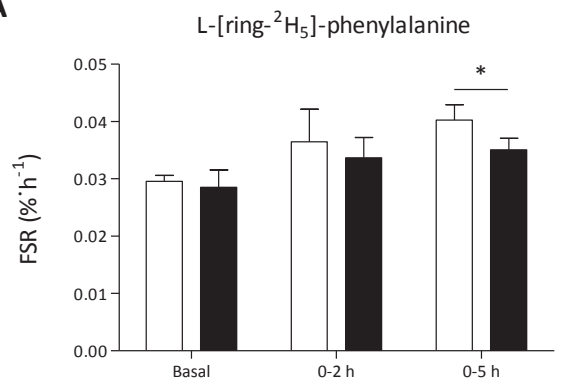

B

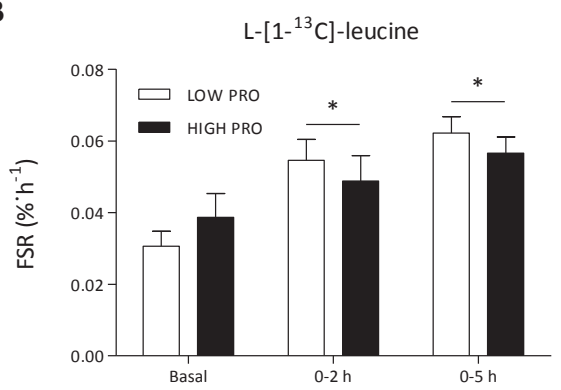

Figure 6.8 | Mean $\left( \pm\right.$ SEM) myofibrillar protein fractional synthetic rates $\left(F S R ; \% \cdot h^{-1}\right.$ ) based on the L-[ring- $\left.{ }^{2} \mathrm{H}_{5}\right]-$ phenylalanine (A) and $\mathrm{L}-\left[1-{ }^{13} \mathrm{C}\right]$-leucine (B) tracer during the fasted state (basal) and after the ingestion of $25 \mathrm{~g}$ whey protein in healthy older males who consumed a low $\left(0.7 \mathrm{~g} \cdot \mathrm{kg}^{-1} \cdot \mathrm{d}^{-1}, \mathrm{n}=12\right)$ or high $\left(1.5 \mathrm{~g} \cdot \mathrm{kg}^{-1} \cdot \mathrm{d}^{-1}, \mathrm{n}=12\right)$ protein diet for 14 days prior to the infusion trial. A: Basal vs $0-2 \mathrm{~h}$ : Time $P=0.108$, Treatment $P=0.619$, TimexTreatment $P=0.808$; Basal vs $0-5$ h: Time $\mathrm{P}=0.001$, Treatment $\mathrm{P}=0.226$, TimexTreatment $\mathrm{P}=0.342$. B: Basal vs $0-2 \mathrm{~h}$ : Time $\mathrm{P}=0.025$, Treatment $\mathrm{P}=0.817$, TimexTreatment $\mathrm{P}=0.335$; Basal vs $0-5$ h: Time $\mathrm{P}<0.001$, Treatment $\mathrm{P}=0.777$, TimexTreatment $\mathrm{P}=0.245$. * Significantly different from basal. 


\section{$\mathrm{L}-\left[1-{ }^{13} \mathrm{C}\right]$-phenylalanine}

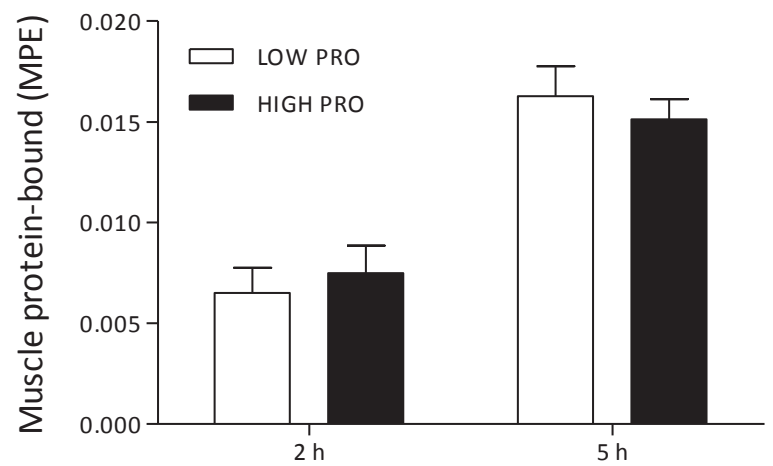

Figure 6.9 | Mean $( \pm$ SEM) myofibrillar protein-bound L-[1-13 C]-phenylalanine enrichments (mole percent excess, MPE)

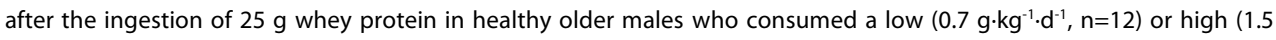
$\mathrm{g} \cdot \mathrm{kg}^{-1} \cdot \mathrm{d}^{-1}, \mathrm{n}=12$ ) protein diet for 14 days prior to the infusion trial. $2 \mathrm{~h}: \mathrm{P}=0.599 ; 5 \mathrm{~h}: \mathrm{P}=0.526$. 


\section{Discussion}

In the present study we observed that habituation to a low $\left(0.7 \mathrm{~g} \cdot \mathrm{kg}^{-1} \cdot \mathrm{d}^{-1}\right)$ when compared with a high $\left(1.5 \mathrm{~g} \mathrm{~kg}^{-1} \cdot \mathrm{d}^{-1}\right)$ protein intake reduced postprandial splanchnic amino acid retention, allowing more of the dietary protein-derived amino acids to become available in the circulation within a $5 \mathrm{~h}$ postprandial period. This supported maintenance of the postprandial muscle protein synthetic response to the ingestion of $25 \mathrm{~g}$ whey protein, with no differences being observed in either postabsorptive or postprandial muscle protein synthesis rates after habituation to a low or high protein intake.

A protein intake below the Recommended Dietary Allowance (RDA; $0.8 \mathrm{~g} \cdot \mathrm{kg}^{-1} \cdot \mathrm{d}^{-1}$ ) results in a negative protein (nitrogen) balance during the adaptation period (33). A negative protein balance on a day-to-day basis may result in loss of skeletal muscle mass and strength with consequent negative health effects (18). It has been speculated such a dietary induced loss of skeletal muscle mass would mechanistically be attributed to a reduction in basal muscle protein synthesis rates. Recently, we assessed basal muscle protein synthesis rates after 12 weeks of habituation to either a very low $\left(0.4 \mathrm{~g} \cdot \mathrm{kg}^{-1} \cdot \mathrm{d}^{-1}\right)$ compared with high $\left(2.4 \mathrm{~g} \cdot \mathrm{kg}^{-1} \cdot \mathrm{d}^{-1}\right)$ protein intake in young individuals (34). In contrast to our hypothesis, it was observed that the low protein diet did not lower basal, postabsorptive muscle protein synthesis rates. In the current study we confirm these previous findings, by showing that basal myofibrillar protein synthesis rates do not differ after two weeks of habituation to a low $\left(0.7 \mathrm{~g} \cdot \mathrm{kg}^{-1} \cdot \mathrm{d}^{-1}\right)$ versus high $\left(1.5 \mathrm{~g} \cdot \mathrm{kg}^{-1} \cdot \mathrm{d}^{-1}\right)$ protein intake in older males (Figure 6.8). Post-absorptive myofibrillar protein synthesis rates assessed using both the intravenous L[ring ${ }^{2} \mathrm{H}_{5}$ ]-phenylalanine tracer $\left(0.030 \pm 0.001\right.$ vs $\left.0.029 \pm 0.003 \% \cdot \mathrm{h}^{-1}\right)$ as well as the intravenous plus oral L-[1-13 C]-leucine tracer $\left(0.031 \pm 0.004\right.$ vs $\left.0.039 \pm 0.007 \% \cdot h^{-1}\right)$ did not differ after two weeks of habituation to either a low or high protein intake.

Besides basal muscle protein synthesis, skeletal muscle mass maintenance is also largely determined by the capacity to increase muscle protein synthesis rates after food intake $(1,35)$. The stimulation of muscle protein synthesis rates after protein ingestion is dependent on a cascade of processes, including dietary protein digestion, amino acid absorption, and splanchnic amino acid retention that regulate the postprandial availability of dietary protein-derived amino acids $(2,36)$. In the current study, we applied continuous infusions of stable isotope-labeled amino acids in combination with the ingestion of intrinsically labeled protein to assess protein digestion and absorption kinetics after the ingestion of $25 \mathrm{~g}$ whey protein. We observed that habituation to a low compared with high protein intake did not affect dietary protein digestion and absorption kinetics (i.e. the rate of appearance of dietary protein-derived amino acids in the circulation; Figure 6.5A). Interestingly, splanchnic amino acid retention was reduced after habituation to a low $(39 \pm 1 \%)$ versus high protein intake (44 $\pm 2 \%$; Figure 6.6$)$. As such, an overall greater amount of the dietary protein-derived amino acids become available in the circulation during the $5 \mathrm{~h}$ postprandial period after habituation to a low protein intake. When expressed in absolute amounts $15.2 \pm 0.3 \mathrm{~g}$ $(61 \pm 1 \%)$ as opposed to $14.0 \pm 0.4 \mathrm{~g}(56 \pm 2 \%)$ of the protein-derived amino acids $(25 \mathrm{~g})$ were released into the circulation during the $5 \mathrm{~h}$ postprandial period after a low versus high protein intake, respectively. Assuming that $\sim 20 \%$ of the dietary protein-derived amino acids that are released into the circulation are being used for de novo muscle protein synthesis (17), a seemingly small difference of $\sim 1.2 \mathrm{~g}$ more amino acids being released per meal could have a substantial impact with up to $1.3 \mathrm{~kg}$ more skeletal muscle mass being synthesized over the course of a year. In short, we extend on previous splanchnic amino acid retention data (8-10, 37-41) by showing that habituation to a low protein intake reduces splanchnic amino acid retention, allowing relatively more of the dietary protein-derived amino acids to be released into the circulation to support muscle and/or organ turnover. 
Postprandial muscle protein synthesis rates were assessed using continuous intravenous infusion of $\mathrm{L}$-[ring $\left.-{ }^{2} \mathrm{H}_{5}\right]$-phenylalanine and measuring $\mathrm{L}$-[ring $\left.-{ }^{2} \mathrm{H}_{5}\right]$-phenylalanine enrichments in the plasma free amino acid pool as well as the myofibrillar protein-bound fraction. We demonstrate that the ingestion of $25 \mathrm{~g}$ whey protein significantly increased myofibrillar protein synthesis rates from basal rates when assessed over a $5 \mathrm{~h}$ postprandial period (Figure 6.8A). Postprandial myofibrillar protein synthesis rates did not differ after habituation to a low protein intake $\left(0.040 \pm 0.003 \% \cdot h^{-1}\right)$ when compared with high protein intake $\left(0.035 \pm 0.002 \% \cdot \mathrm{h}^{-1}\right)$. Since the measurement of muscle protein synthesis rates requires steady state precursor pool enrichments, we also applied continuous intravenous infusion of $\mathrm{L}-\left[1-{ }^{13} \mathrm{C}\right]$-leucine in combination with the ingestion of $\mathrm{L}-\left[1-{ }^{13} \mathrm{C}\right]-$ leucine-labeled protein $(24,42)$. This method prevents a temporal dilution in precursor pool enrichments due to protein intake, allowing near 'perfect' steady state measurements throughout the postprandial period (Figure 6.4B). Using this approach we also observed an increase in myofibrillar protein synthesis rates above basal rates after ingesting $25 \mathrm{~g}$ whey protein (Figure 6.8B). Postprandial myofibrillar protein synthesis rates assessed over the early $2 \mathrm{~h}$ and entire $5 \mathrm{~h}$ postprandial period averaged $0.055 \pm 0.006$ vs $0.049 \pm 0.007 \% \cdot h^{-1}$ and $0.062 \pm 0.005$ vs $0.057 \pm 0.005$ $\% \cdot h^{-1}$ after habituation to a low vs high protein intake, respectively. Again, no differences were observed in postprandial myofibrillar protein synthesis rates between treatments assessed with either the $\mathrm{L}-\left[\right.$ ring $\left.-{ }^{2} \mathrm{H}_{5}\right]$-phenylalanine or $\mathrm{L}-\left[1-{ }^{13} \mathrm{C}\right]$-leucine tracer. Furthermore, we applied the ingestion of intrinsically $\mathrm{L}-\left[1-{ }^{13} \mathrm{C}\right]$-phenylalanine-labeled protein with an enrichment level of 36 $\mathrm{MPE}$, which allows us to assess the postprandial incorporation of dietary protein-derived amino acids into muscle protein (28-30). After the ingestion of the intrinsically L-[1- $\left.{ }^{13} \mathrm{C}\right]$-phenylalaninelabeled protein, myofibrillar protein-bound $\mathrm{L}-\left[1-{ }^{13} \mathrm{C}\right]$-phenylalanine enrichments increased over time, with no differences being observed after habituation to a low when compared with a high protein intake $(0.016 \pm 0.001$ vs $0.015 \pm 0.001$; Figure 6.9$)$. These data provide further confirmation that habituation to a low $\left(0.7 \mathrm{~g} \cdot \mathrm{kg}^{-1} \cdot \mathrm{d}^{-1}\right)$ versus a high $\left(1.5 \mathrm{~g} \cdot \mathrm{kg}^{-1} \cdot \mathrm{d}^{-1}\right)$ protein intake does not modulate postprandial muscle protein synthesis rates.

In the current study we provided close to the Estimated Average Requirement (EAR) for daily protein intake $\left(\sim 0.7 \mathrm{~g} \cdot \mathrm{kg}^{-1} \cdot \mathrm{d}^{-1}\right)$ in the low protein intake group. The EAR is the average daily nutrient intake level estimated to meet the requirements of half of the healthy adults of all ages. In the high protein group, we provided $1.5 \mathrm{~g}$ protein per $\mathrm{kg}$ body weight per day, a protein intake level that is recommended to older adults who have an acute or chronic disease (43). We show that basal muscle protein synthesis rates as well as the postprandial muscle protein synthetic response to the ingestion of $25 \mathrm{~g}$ whey protein are maintained over this wide range of habitual protein intakes. Interestingly, the present study shows that the gut may play a role in allowing maintenance of a proper muscle protein synthetic response to food intake by allowing more of the dietary proteinderived amino acids to become available in the circulation when consuming a low protein diet. Preventing a decline in both post-absorptive and postprandial muscle protein synthesis rates by modulating plasma amino acid availability may be one of the mechanisms to facilitate muscle mass maintenance over a wide range of habitual protein intake levels (within or beyond 0.7-1.5 $\left.\mathrm{g} \cdot \mathrm{kg}^{-1} \cdot \mathrm{d}^{-1}\right)$. This would explain previous observations by Martens et al. (21) reporting no significant decline in fat-free mass after as much as 12 weeks of habituation to a very low protein intake (0.4 $\left.\mathrm{g} \cdot \mathrm{kg}^{-1} \cdot \mathrm{d}^{-1}\right)$.

In conclusion, habituation to a low $\left(0.7 \mathrm{~g} \cdot \mathrm{kg}^{-1} \cdot \mathrm{d}^{-1}\right)$ compared with a high $\left(1.5 \mathrm{~g} \cdot \mathrm{kg}^{-1} \cdot \mathrm{d}^{-1}\right)$ protein intake increases postprandial release of dietary protein-derived amino acids into the circulation, with no subsequent changes in the postprandial muscle protein synthetic response to protein ingestion. 


\section{REFERENCES}

1. Burd NA, Tang JE, Moore DR, Phillips SM. Exercise training and protein metabolism: influences of contraction, protein intake, and sex-based differences. Journal of applied physiology (Bethesda, Md : 1985) 2009;106(5):1692-701.

2. Burd NA, Gorissen SH, van Loon LJ. Anabolic resistance of muscle protein synthesis with aging. Exercise and sport sciences reviews 2013;41(3):169-73.

3. Boirie Y, Dangin M, Gachon P, Vasson MP, Maubois JL, Beaufrere B. Slow and fast dietary proteins differently modulate postprandial protein accretion. Proc Natl Acad Sci U S A 1997;94(26):14930-5.

4. Dangin M, Boirie Y, Garcia-Rodenas C, Gachon P, Fauquant J, Callier P, Ballevre O, Beaufrere B. The digestion rate of protein is an independent regulating factor of postprandial protein retention. Am J Physiol Endocrinol Metab 2001;280(2):E340-8.

5. Koopman R, Crombach N, Gijsen AP, Walrand S, Fauquant J, Kies AK, Lemosquet S, Saris WH, Boirie Y, van Loon $\mathrm{LJ}$. Ingestion of a protein hydrolysate is accompanied by an accelerated in vivo digestion and absorption rate when compared with its intact protein. Am J Clin Nutr 2009;90(1):106-15.

6. Pennings B, Boirie Y, Senden JM, Gijsen AP, Kuipers H, van Loon LJ. Whey protein stimulates postprandial muscle protein accretion more effectively than do casein and casein hydrolysate in older men. Am J Clin Nutr 2011;93(5):997-1005.

7. West DW, Burd NA, Coffey VG, Baker SK, Burke LM, Hawley JA, Moore DR, Stellingwerff T, Phillips SM. Rapid aminoacidemia enhances myofibrillar protein synthesis and anabolic intramuscular signaling responses after resistance exercise. Am J Clin Nutr 2011;94(3):795-803.

8. Boirie Y, Gachon P, Beaufrere B. Splanchnic and whole-body leucine kinetics in young and elderly men. Am J Clin Nutr 1997;65(2):489-95.

9. Volpi E, Mittendorfer B, Wolf SE, Wolfe RR. Oral amino acids stimulate muscle protein anabolism in the elderly despite higher first-pass splanchnic extraction. Am J Physiol 1999;277(3 Pt 1):E513-20.

10. Gorissen SH, Burd NA, Hamer HM, Gijsen AP, Groen BB, van Loon LJ. Carbohydrate coingestion delays dietary protein digestion and absorption but does not modulate postprandial muscle protein accretion. J Clin Endocrinol Metab 2014;99(6):2250-8.

11. Timmerman KL, Lee JL, Dreyer HC, Dhanani S, Glynn EL, Fry CS, Drummond MJ, Sheffield-Moore M, Rasmussen BB, Volpi E. Insulin stimulates human skeletal muscle protein synthesis via an indirect mechanism involving endothelial-dependent vasodilation and mammalian target of rapamycin complex 1 signaling. J Clin Endocrinol Metab 2010;95(8):3848-57.

12. Timmerman KL, Lee JL, Fujita S, Dhanani S, Dreyer HC, Fry CS, Drummond MJ, Sheffield-Moore M, Rasmussen BB, Volpi E. Pharmacological vasodilation improves insulin-stimulated muscle protein anabolism but not glucose utilization in older adults. Diabetes 2010;59(11):2764-71.

13. Drummond MJ, Glynn EL, Fry CS, Timmerman KL, Volpi E, Rasmussen BB. An increase in essential amino acid availability upregulates amino acid transporter expression in human skeletal muscle. Am J Physiol Endocrinol Metab 2010;298(5):E1011-8.

14. Dickinson JM, Drummond MJ, Coben JR, Volpi E, Rasmussen BB. Aging differentially affects human skeletal muscle amino acid transporter expression when essential amino acids are ingested after exercise. Clin Nutr 2013;32(2):273-80.

15. Cuthbertson D, Smith K, Babraj J, Leese G, Waddell T, Atherton P, Wackerhage H, Taylor PM, Rennie MJ. Anabolic signaling deficits underlie amino acid resistance of wasting, aging muscle. Faseb J 2005;19(3):422-4.

16. Guillet C, Prod'homme M, Balage M, Gachon P, Giraudet C, Morin L, Grizard J, Boirie Y. Impaired anabolic response of muscle protein synthesis is associated with S6K1 dysregulation in elderly humans. Faseb J 2004;18(13):1586-7.

17. Groen BB, Horstman AM, Hamer HM, de Haan M, van Kranenburg J, Bierau J, Poeze M, Wodzig WK, Rasmussen BB, van Loon LJ. Post-Prandial Protein Handling: You Are What You Just Ate. PLoS One 2015;10(11):e0141582.

18. Houston DK, Nicklas BJ, Ding J, Harris TB, Tylavsky FA, Newman AB, Lee JS, Sahyoun NR, Visser M, Kritchevsky $\mathrm{SB}$. Dietary protein intake is associated with lean mass change in older, community-dwelling adults: the Health, Aging, and Body Composition (Health ABC) Study. Am J Clin Nutr 2008;87(1):150-5.

19. Bauer JM, Verlaan S, Bautmans I, Brandt K, Donini LM, Maggio M, McMurdo ME, Mets T, Seal C, Wijers SL, et al. Effects of a vitamin $D$ and leucine-enriched whey protein nutritional supplement on measures of sarcopenia in older adults, the PROVIDE study: a randomized, double-blind, placebo-controlled trial. J Am Med Dir Assoc 2015;16(9):740-7.

20. Norton C, Toomey C, McCormack WG, Francis P, Saunders J, Kerin E, Jakeman P. Protein Supplementation at Breakfast and Lunch for 24 Weeks beyond Habitual Intakes Increases Whole-Body Lean Tissue Mass in Healthy Older Adults. J Nutr 2015.

21. Martens EA, Gonnissen HK, Gatta-Cherifi B, Janssens PL, Westerterp-Plantenga MS. Maintenance of energy expenditure on high-protein vs. high-carbohydrate diets at a constant body weight may prevent a positive energy balance. Clin Nutr 2015;34(5):968-75.

22. Tieland M, van de Rest O, Dirks ML, van der Zwaluw N, Mensink M, van Loon LJ, de Groot LC. Protein supplementation improves physical performance in frail elderly people: a randomized, double-blind, placebocontrolled trial. J Am Med Dir Assoc 2012;13(8):720-6.

23. Millward DJ. An adaptive metabolic demand model for protein and amino acid requirements. The British journal of nutrition 2003;90(2):249-60. 
24. Burd NA, Cermak NM, Kouw IW, Gorissen SH, Gijsen AP, van Loon LJ. The use of doubly labeled milk protein to measure postprandial muscle protein synthesis rates in vivo in humans. Journal of applied physiology (Bethesda, Md : 1985) 2014;117(11):1363-70.

25. Alberti KG, Zimmet PZ. Definition, diagnosis and classification of diabetes mellitus and its complications. Part 1: diagnosis and classification of diabetes mellitus provisional report of a WHO consultation. Diabet Med 1998;15(7):539-53.

26. Abumrad NN, Rabin D, Diamond MP, Lacy WW. Use of a heated superficial hand vein as an alternative site for the measurement of amino acid concentrations and for the study of glucose and alanine kinetics in man. Metabolism 1981;30(9):936-40.

27. Bergstrom J. Percutaneous needle biopsy of skeletal muscle in physiological and clinical research. Scand J Clin Lab Invest 1975;35(7):609-16.

28. Burd NA, Hamer HM, Pennings B, Pellikaan WF, Senden JM, Gijsen AP, van Loon LJ. Substantial Differences between Organ and Muscle Specific Tracer Incorporation Rates in a Lactating Dairy Cow. PLoS One 2013;8(6):e68109.

29. Pennings B, Pellikaan WF, Senden JM, van Vuuren AM, Sikkema J, van Loon LJ. The production of intrinsically labeled milk and meat protein is feasible and provides functional tools for human nutrition research. J Dairy Sci 2011;94(9):4366-73.

30. van Loon LJ, Boirie Y, Gijsen AP, Fauquant J, de Roos AL, Kies AK, Lemosquet S, Saris WH, Koopman R. The production of intrinsically labeled milk protein provides a functional tool for human nutrition research. J Dairy Sci 2009;92(10):4812-22.

31. Boirie Y, Gachon P, Corny S, Fauquant J, Maubois JL, Beaufrere B. Acute postprandial changes in leucine metabolism as assessed with an intrinsically labeled milk protein. Am J Physiol 1996;271(6 Pt 1):E1083-91.

32. Dangin M, Guillet C, Garcia-Rodenas C, Gachon P, Bouteloup-Demange C, Reiffers-Magnani K, Fauquant J, Ballevre $\mathrm{O}$, Beaufrere $\mathrm{B}$. The rate of protein digestion affects protein gain differently during aging in humans. J Physiol 2003;549(Pt 2):635-44.

33. European Food Safety Authority (EFSA) Panel on Dietetic Products NaAN. Scientific Opinion on Dietary Reference Values for protein. EFSA Journal 2015.

34. Hursel R, Martens EA, Gonnissen HK, Hamer HM, Senden JM, van Loon LJ, Westerterp-Plantenga MS. Prolonged Adaptation to a Low or High Protein Diet Does Not Modulate Basal Muscle Protein Synthesis Rates - A Substudy. PLoS One 2015;10(9):e0137183.

35. Koopman R, van Loon LJ. Aging, exercise, and muscle protein metabolism. Journal of applied physiology (Bethesda, Md : 1985) 2009;106(6):2040-8.

36. Gorissen $\mathrm{SH}$, Remond D, van Loon LJ. The muscle protein synthetic response to food ingestion. Meat science 2015;109:96-100

37. Koopman R, Crombach N, Gijsen AP, Walrand S, Fauquant J, Kies AK, Lemosquet S, Saris WH, Boirie Y, van Loon $\mathrm{LJ}$. Ingestion of a protein hydrolysate is accompanied by an accelerated in vivo digestion and absorption rate when compared with its intact protein. Am J Clin Nutr 2009;90(1):106-15.

38. Koopman R, Walrand S, Beelen M, Gijsen AP, Kies AK, Boirie Y, Saris WH, van Loon LJ. Dietary protein digestion and absorption rates and the subsequent postprandial muscle protein synthetic response do not differ between young and elderly men. J Nutr 2009;139(9):1707-13.

39. Pennings B, Boirie $Y$, Senden JM, Gijsen AP, Kuipers H, van Loon LJ. Whey protein stimulates postprandial muscle protein accretion more effectively than do casein and casein hydrolysate in older men. Am J Clin Nutr 2011;93(5):997-1005.

40. Pennings B, Groen B, de Lange A, Gijsen AP, Zorenc AH, Senden JM, van Loon LJ. Amino acid absorption and subsequent muscle protein accretion following graded intakes of whey protein in elderly men. Am J Physiol Endocrinol Metab 2012;302(8):E992-9.

41. Pennings B, Koopman R, Beelen M, Senden JM, Saris WH, van Loon LJ. Exercising before protein intake allows for greater use of dietary protein-derived amino acids for de novo muscle protein synthesis in both young and elderly men. Am J Clin Nutr 2011;93(2):322-31.

42. Reitelseder S, Agergaard J, Doessing S, Helmark IC, Lund P, Kristensen NB, Frystyk J, Flyvbjerg A, Schjerling P, van Hall G, et al. Whey and casein labeled with L-[1-13C]leucine and muscle protein synthesis: effect of resistance exercise and protein ingestion. Am J Physiol Endocrinol Metab 2011;300(1):E231-42.

43. Bauer J, Biolo G, Cederholm T, Cesari M, Cruz-Jentoft AJ, Morley JE, Phillips S, Sieber C, Stehle P, Teta D, et al. Evidence-based recommendations for optimal dietary protein intake in older people: a position paper from the PROT-AGE Study Group. J Am Med Dir Assoc 2013;14(8):542-59. 



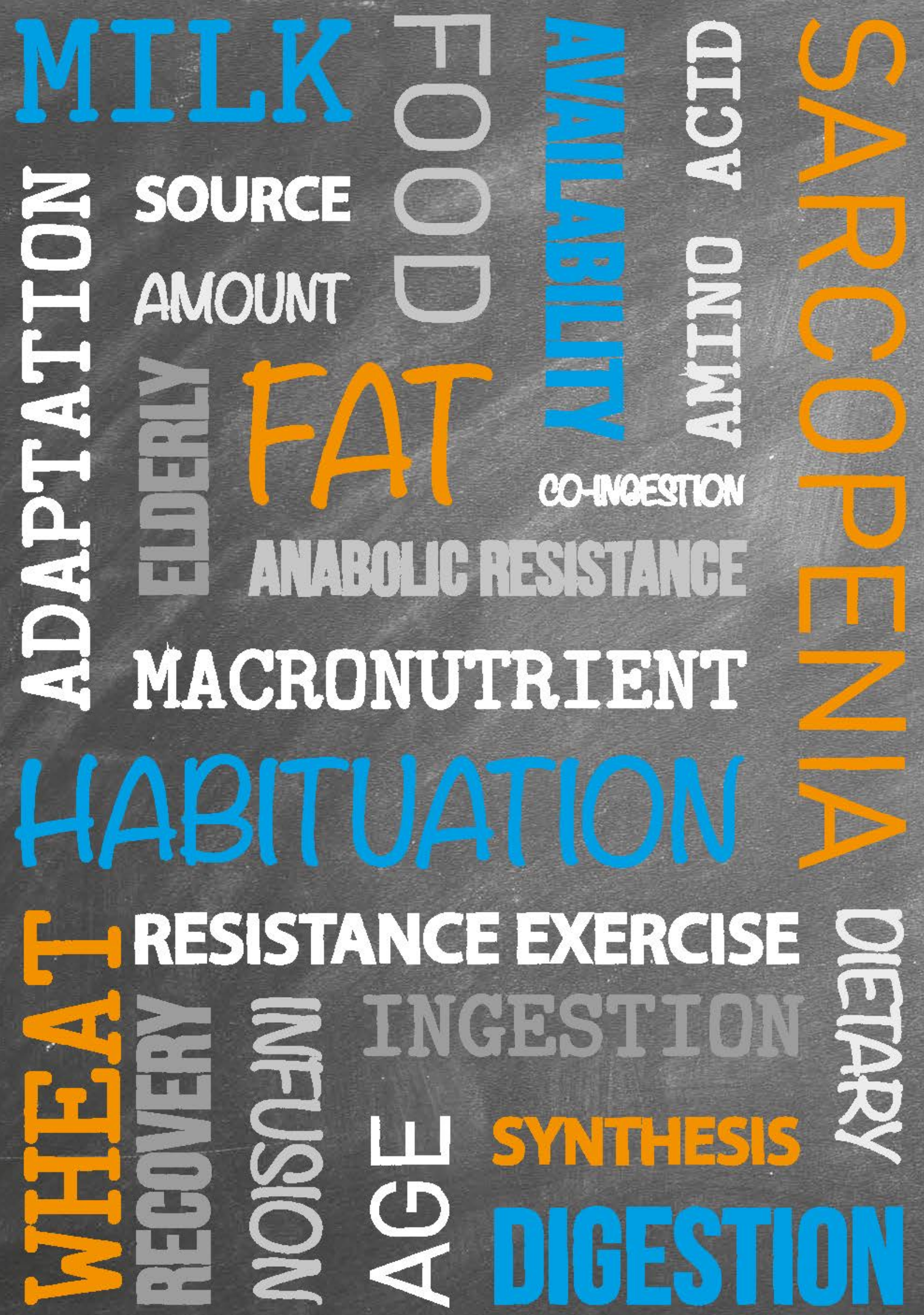




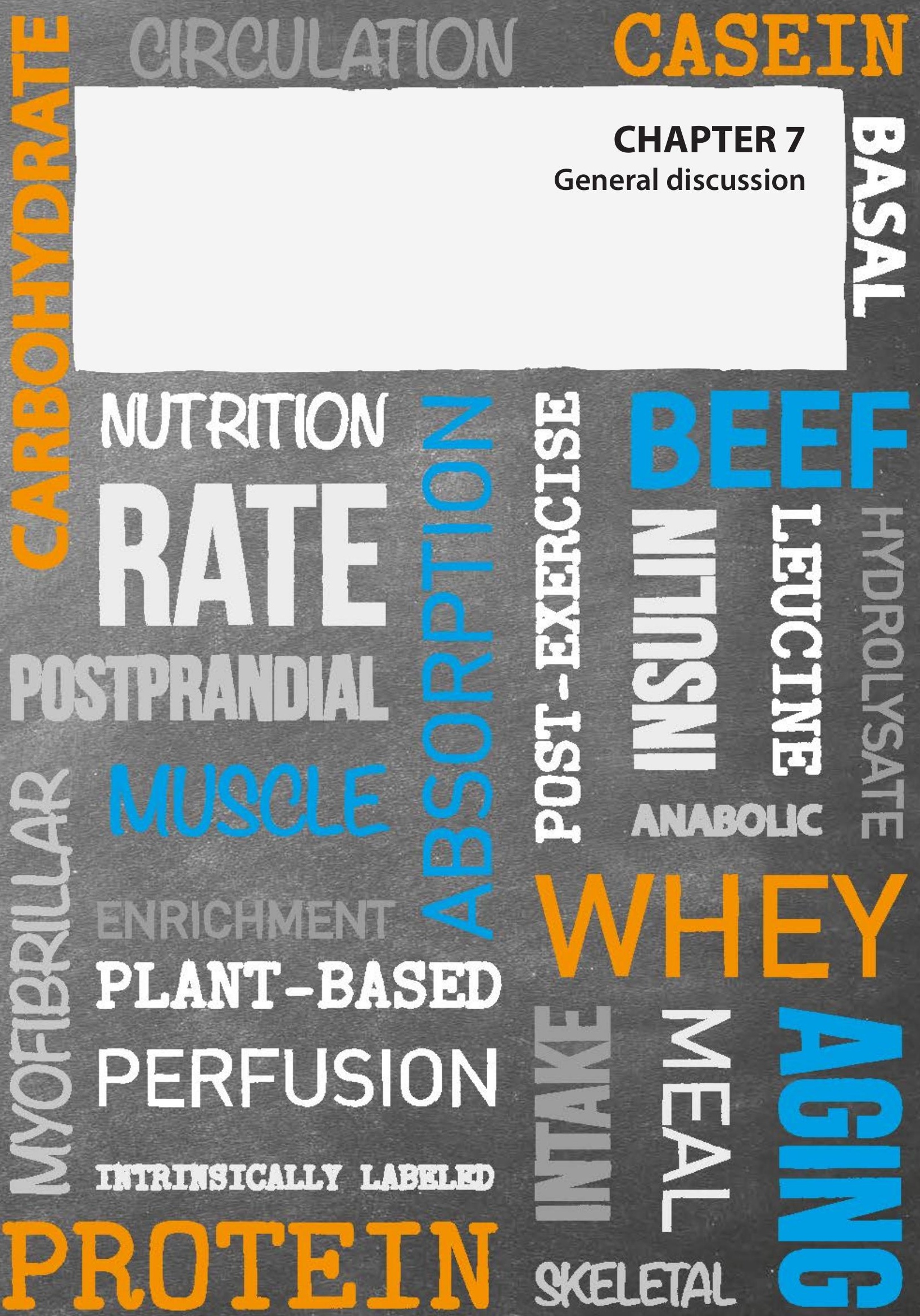


This chapter elaborates on the primary findings of the randomized trials described in the previous chapters. Results are placed in a broader perspective and directions for future research are presented.

\section{PROTEIN HANDLING AFTER MEAL INTAKE}

Multiple studies have shown that muscle protein synthesis rates increase after the ingestion of protein $(1,2)$. Some of these studies compare various types or sources of protein and show that the postprandial muscle protein synthetic response can vary substantially between various protein sources (3-6). Isolated protein sources are typically consumed by athletes after a training session to promote gains in skeletal muscle mass or to recover from exercise. In other circumstances, protein is generally consumed as part of a food product or meal. Food products or meals are composed of all three macronutrients (i.e. protein, carbohydrate, and fat), which may interfere with postprandial protein handling (7). We have shown that carbohydrate co-ingestion with protein delays protein digestion and absorption (chapter 2), whereas fat co-ingestion with protein has less of an impact on protein digestion and amino acid absorption kinetics (chapter 3). Despite the delay in protein digestion and amino acid absorption after carbohydrate co-ingestion, neither carbohydrate nor fat co-ingestion with protein modulates postprandial muscle protein synthesis rates or modifies the incorporation of dietary protein-derived amino acids into de novo skeletal muscle protein $(8,9)$.

Though we now understand the impact of carbohydrate and fat co-ingestion with protein on postprandial protein handling in vivo in humans when dietary protein is provided in a liquid protein beverage $(8,9)$, there are hardly any data on the anabolic response following the ingestion of a normal, mixed meal. Both the macronutrient composition of the meal as well as the matrix of the food consumed may strongly affect postprandial protein handling (10). Meals or food products are composed of a combination of all three macronutrients and also contain micronutrients and various anti-nutritional factors. Moreover, different food products can have a different texture. Food texture has been shown to modulate protein digestion and amino acid absorption kinetics and, as such, postprandial protein synthesis rates (11). For example, minced beef has been shown to be more rapidly digested and absorbed when compared with beef steak, thereby promoting a more positive postprandial net protein balance (12). Besides food texture, it has also been shown that food preparation, such as cooking time and temperature, can influence protein digestion and the subsequent appearance of dietary protein-derived amino acids into the circulation (13). This may be, at least partly, attributed to modifications of dietary proteins at the structural level, with a gradual denaturation of proteins followed by the formation of protein aggregates, which are more or less accessible to the various digestive enzymes (14).

We compared milk and beef ingestion to better understand how two of the most common protein-dense food products consumed within a Western diet affect postprandial protein handling (chapter 4). These two food products differ in macronutrient composition, texture, and preparation conditions. Despite the more rapid protein digestion and amino acid absorption following beef ingestion, milk consumption resulted in a greater early rise in the muscle protein synthetic response during recovery from resistance type exercise (15). This implies that other factors besides dietary protein digestion and amino acid absorption modulate the muscle protein synthetic response. For example, the greater muscle protein synthetic response to the ingestion of whey protein when compared with intact, micellar casein has been attributed to the more rapid digestion and absorption of whey protein when compared with intact casein (16). However, increasing the rate of protein digestion of casein by prior hydrolysis, creating casein hydrolysate, does not fully compensate for the greater muscle protein synthetic response observed after 
ingesting a similar amount of whey protein (4). Clearly, increasing the rate of protein digestion and amino acid absorption by hydrolysis of an intact protein or by changing food structure by mincing meat can increase the postprandial muscle protein synthesis rates $(3,4,12,17)$, but more factors determine the postprandial muscle protein synthetic response to food ingestion. One of these factors is the leucine content of the protein source and the subsequent postprandial rise in circulating or intramuscular leucine concentrations. Besides serving as a precursor for protein synthesis, leucine has the capacity to directly activate mTOR signaling and subsequently stimulate muscle protein synthesis (18). In chapter 4 we observed that the ingestion of minced beef results in a greater increase in postprandial plasma leucine concentrations when compared with the ingestion of milk. Nevertheless, the ingestion of milk resulted in a greater postprandial muscle protein synthetic response when compared with minced beef (15). Again, these data show that there are more factors besides dietary protein digestion and absorption kinetics or leucine content of the ingested meal that determine the postprandial muscle protein synthetic response.

\section{ANIMAL-DERIVED VERSUS PLANT-BASED FOODS}

Meals generally contain several food items and provide a combination of various types and sources of protein. Within one meal, both animal-derived proteins as well as plant-based proteins may be consumed (19). Evidence shows that the muscle protein synthetic response to the ingestion of soy protein is lower when compared with the ingestion of several animal-derived proteins $(5,6,20,21)$. Based on these data, it is generally assumed that all plant-based proteins have lower anabolic properties when compared to animal-derived protein sources. The possible lower anabolic properties of plant-based proteins may be attributed to lower digestibility and/or higher splanchnic amino acid retention (22). The latter may be attributed to a suboptimal amino acid composition (23), such as a lower essential amino acid content or a low lysine and/or methionine content in particular. Moreover, most plant-based proteins have a relatively low leucine content, which may further explain the lower muscle protein synthetic response when compared with the ingestion of animal-derived proteins. Several strategies have been proposed to augment the anabolic response following the ingestion of a single bolus of plant-based proteins, including 1) fortification with specific essential amino acids such as leucine, lysine, and/or methionine, 2) selective breeding of plants to improve the amino acid composition of the protein, 3 ) consumption of greater amounts of protein, or 4) ingesting a combination of multiple protein sources to provide a more balanced amino acid profile (22).

In chapter 5 we studied the anabolic properties of the most widely consumed plant-based protein source, i.e. wheat protein (24). We demonstrate that the muscle protein synthetic response to the ingestion of wheat protein is lower when compared with milk protein. This might be due to the relatively low leucine and/or lysine content (and/or moderate methionine content) of wheat protein when compared with milk protein. To improve the anabolic properties of wheat protein we applied one of the above mentioned strategies: providing a higher dose of wheat protein matching for the leucine (and essential amino acid) content of milk protein. This strategy seems effective and significantly improved the muscle protein synthetic response to the ingestion of wheat protein. Interestingly, the ingestion of the higher dose of wheat protein resulted in a greater increase in postprandial muscle protein synthesis rates when compared with the ingestion of a leucine-matched amount of whey protein, despite the faster digestion of whey protein and the higher postprandial peak in plasma leucine and essential amino acid concentrations. This confirms previous speculations that the rate of dietary protein digestion and amino acid absorption and the postprandial plasma leucine concentrations are certainly not the only factors that drive the 
postprandial increase in muscle protein synthesis rates. Obviously, the postprandial muscle protein synthetic response to feeding can also be modulated by simply changing the amount of protein consumed (25-29).

Another strategy to improve the anabolic properties of plant-based proteins is to ingest a combination of various protein sources to provide a more balanced amino acid profile $(22,30,31)$. Individual plant-based proteins are generally low in either lysine or methionine (22). Ingesting a combination of two plant-based proteins might overcome a specific deficiency in either lysine or methionine. Animal-derived proteins have a relatively high leucine and essential amino acid content. Consequently, combining plant-based proteins with dairy proteins may result in protein blends with greater anabolic properties. As previously mentioned, meals generally contain multiple food items and provide proteins from various sources. It is likely that mixed meals already provide a more preferred spectrum of essential and non-essential amino acids. Nevertheless, more research is warranted on the anabolic properties of protein blends combining plant-based protein sources or mixtures combining both plant-based and animal-derived proteins. This will provide relevant information that can be used to define dietary strategies to prevent or delay the onset of sarcopenia and support healthy aging. Moreover, this information can contribute to the development of more sustainable and cost-effective nutritional strategies that support muscle mass preservation in various conditions in people living in less privileged regions of the world.

\section{ProteIn INTAKE THROUGHOUT THE DAY}

Most of our knowledge on postprandial protein handling is based upon research investigating the muscle protein synthetic response to the ingestion of a single meal-like bolus of protein (32). However, dietary protein is mostly consumed at three occasions throughout the day (i.e. breakfast, lunch, and dinner), with approximately $4-6 \mathrm{~h}$ in between meals $(19,33)$. Little is known on how protein intake distributed throughout the day affects skeletal muscle mass maintenance.

Dinner generally contains the larger amount of protein, while breakfast and lunch contain smaller amounts of protein (33). It could be speculated that the higher dose of protein consumed with dinner exceeds the amount that is required for (maximal) postprandial stimulation of muscle protein synthesis $(25,28,29,34)$. It has previously been suggested that the postprandial muscle protein synthetic response to feeding is maximized when a certain amount of amino acids is taken up into the muscle, with no further stimulation when more amino acids are continually being provided $(35,36)$. Theoretically, each meal should provide a strong anabolic stimulus and, therefore, all main meals should contain sufficient dietary protein to allow muscle protein synthesis rates to increase.

Breakfast and lunch typically contain relatively small amounts of protein (33). Such smaller doses of protein (10-20 g) may not provide sufficient amino acids for proper postprandial stimulation of muscle protein synthesis rates $(28,29)$. Moreover, we $(8,37)$ and others $(38)$ observed a latency period prior to the stimulation of muscle protein synthesis rates in older individuals. Therefore, it could be speculated that the more delayed postprandial rise in muscle protein synthesis in the older population is limited by amino acid availability during the later stages of the postprandial period. As such, it is of key importance to achieve a sufficient rise in amino acid availability as well as a prolonged delivery of amino acids to the muscle by ingesting an adequate amount of protein. Protein supplementation at breakfast and lunch has been shown effective in improving lean body mass in older individuals $(39,40)$. In accordance, it has been shown that a more equal distribution of protein intake throughout the day improves muscle protein synthesis rates during the day more effectively than skewing protein intake toward the evening meal (41-44). Besides a redistribution 
of protein intake over the main meals, we have recently introduced the concept of pre-sleep protein feeding as a strategy to optimize net muscle protein balance. As the overnight period is an important period during which net muscle protein balance is negative, we hypothesized that protein administration prior to or during sleep may increase protein synthesis rates during sleep and, as such, help to compensate for any anabolic resistance to food intake during the day. In agreement, we reported that protein ingestion before sleep effectively stimulates overnight muscle protein synthesis rates $(45,46)$ and can promote greater gains in muscle mass and strength when applied in combination with a resistance type exercise training program (47). Consequently, it may be preferred to combine a balanced protein intake throughout the day (i.e. equal amount of protein with breakfast, lunch, and dinner) with an additional bolus of dietary protein ingested prior to sleep. It seems likely that (optimal) stimulation of muscle protein synthesis rates following each meal and during the overnight period would represent an effective strategy to maintain skeletal muscle mass.

\section{ADAPTATION TO PROTEIN INTAKE}

Muscle mass maintenance is largely regulated by basal muscle protein synthesis rates and the postprandial muscle protein synthetic response to protein ingestion (1). We hypothesized that both basal and postprandial muscle protein synthesis rates are modulated by the amount of protein regularly consumed in the diet $(23,48,49)$. In a study by Hursel et al., we first assessed the impact of a low versus high protein diet on basal muscle protein synthesis rates and observed no differences following 3 months of habituation to a low versus high protein diet (50). In chapter 6 we investigated whether the level of habitual protein intake modulates the postprandial muscle protein synthetic response to ingestion of $25 \mathrm{~g}$ whey protein. We observed no differences in either basal or postprandial muscle protein synthesis rates after 2 weeks of habituation to low $(0.7$ $\mathrm{g} / \mathrm{kg} / \mathrm{d})$ versus high $(1.5 \mathrm{~g} / \mathrm{kg} / \mathrm{d})$ protein intake. Interestingly, splanchnic retention of dietary protein-derived amino acids was lower after habituation to a low compared with high protein intake. Due to lower splanchnic amino acid retention, more of the dietary protein-derived amino acids were made available for the postprandial rise in muscle protein synthesis. Consequently, the reduced splanchnic amino acid retention may have compensated for an attenuated or blunted postprandial muscle protein synthetic response that could have developed during habituation to a low protein intake. Nonetheless, the postprandial muscle protein synthetic response to the ingestion of a single meal-like bolus of protein was shown to be maintained following adaptation to a low protein intake diet. The study described in chapter 6 provided close to the Estimated Average Requirement (EAR) for daily protein intake $(\sim 0.7 \mathrm{~g} / \mathrm{kg} / \mathrm{d})$ in the low protein intake group. It remains to be investigated whether the human body can maintain the normal postprandial muscle protein synthetic response to feeding when protein intake levels fall well below the EAR for protein intake. It seems likely that the human body has the capacity to adapt over a wide range of protein intake levels. Though scientifically challenging, it remains to be investigated within what ranges of protein intake skeletal muscle tissue, as well as various organs, can remain to function properly. It would also be interesting to investigate whether the capacity of the body to adapt to changes in the amount of protein regularly consumed in the diet is modulated with the aging process. Clearly, our data underline the plasticity of the human body and show that skeletal muscle tissue can adapt to the level of dietary protein intake. 


\section{FUTURE PERSPECTIVES}

Multiple previous studies and all chapters in this dissertation provide evidence that dietary protein ingestion stimulates muscle protein synthesis. The stimulation of muscle protein synthesis is dependent on various factors including protein digestibility, protein digestion and amino acid absorption kinetics, as well as amino acid composition of the protein. Components present in food products or the meal may affect postprandial protein handling. Moreover, lifestyle factors including physical activity and habitual food intake can influence the muscle protein synthetic response to feeding. The stimulation of muscle protein synthesis by dietary protein intake and its relevance to muscle mass maintenance is rather complex and some important issues need to be addressed in the future:

- The current dissertation provides evidence that carbohydrate or fat co-ingested with protein can influence dietary protein digestion and amino acid absorption kinetics. It remains to be investigated how the combination of all three macronutrients affect postprandial protein handling.

- Most studies have provided dietary protein in a liquid protein beverage. Protein digestion and absorption may differ when protein is consumed within a solid product. It remains to be investigated whether this would differently affect postprandial muscle protein synthesis.

- We have demonstrated that the ingestion of different protein-dense foods can result in different postprandial muscle protein synthesis rates. These food products are typically consumed as part of a meal together with the consumption of other food items. It would be interesting to examine the postprandial muscle protein synthetic response following coingestion of various macronutrients, micronutrients, and non-nutritive components that are part of a normal meal.

- We have shown that the ingestion of wheat protein increases muscle protein synthesis rates, provided that ample protein is consumed. More research is warranted to assess the anabolic properties of other plant-based proteins and protein blends by combining plant-based protein sources or a mix between plant-based and animal-derived proteins.

- Though we have a clear understanding of the regulation of postprandial protein handling following the ingestion of a single bolus of protein, more research is warranted on how protein intake throughout the day affects muscle mass maintenance. We propose to rebalance protein intake throughout the day and provide an additional bolus of protein prior to sleep. It needs to be investigated whether this strategy is effective in supporting skeletal muscle mass maintenance in various conditions. In addition, other methodologies could be applied, such as heavy water methodology, to assess muscle protein synthesis rates under free-living conditions over longer time periods. This will yield information on whether the muscle protein synthetic response to the ingestion of a single protein meal can be translated to changes in muscle mass in the long term.

- We provide evidence that postprandial protein handling can be modulated by the amount of protein that is typically consumed in the diet. The exact range of protein intake levels at which the body is able to adapt to remains to be investigated. Moreover, it is of interest to examine whether the capacity to adapt is compromised with aging. 


\section{REFERENCES}

1. Burd NA, Tang JE, Moore DR, Phillips SM. Exercise training and protein metabolism: influences of contraction, protein intake, and sex-based differences. Journal of applied physiology (Bethesda, Md : 1985) 2009;106(5):1692-701.

2. Koopman R, van Loon LJ. Aging, exercise, and muscle protein metabolism. Journal of applied physiology (Bethesda, Md : 1985) 2009;106(6):2040-8.

3. Koopman R, Crombach N, Gijsen AP, Walrand S, Fauquant J, Kies AK, Lemosquet S, Saris WH, Boirie Y, van Loon $\mathrm{L}$. Ingestion of a protein hydrolysate is accompanied by an accelerated in vivo digestion and absorption rate when compared with its intact protein. Am J Clin Nutr 2009;90(1):106-15.

4. Pennings B, Boirie $Y$, Senden JM, Gijsen AP, Kuipers H, van Loon LJ. Whey protein stimulates postprandial muscle protein accretion more effectively than do casein and casein hydrolysate in older men. Am J Clin Nutr 2011;93(5):997-1005.

5. Tang JE, Moore DR, Kujbida GW, Tarnopolsky MA, Phillips SM. Ingestion of whey hydrolysate, casein, or soy protein isolate: effects on mixed muscle protein synthesis at rest and following resistance exercise in young men. Journal of applied physiology (Bethesda, Md : 1985) 2009;107(3):987-92.

6. Yang Y, Churchward-Venne TA, Burd NA, Breen L, Tarnopolsky MA, Phillips SM. Myofibrillar protein synthesis following ingestion of soy protein isolate at rest and after resistance exercise in elderly men. Nutr Metab (Lond) 2012;9(1):57.

7. Burd NA, Gorissen SH, van Loon LJ. Anabolic resistance of muscle protein synthesis with aging. Exercise and sport sciences reviews 2013;41(3):169-73.

8. Gorissen SH, Burd NA, Hamer HM, Gijsen AP, Groen BB, van Loon LJ. Carbohydrate coingestion delays dietary protein digestion and absorption but does not modulate postprandial muscle protein accretion. J Clin Endocrinol Metab 2014;99(6):2250-8.

9. Gorissen SH, Burd NA, Kramer IF, van Kranenburg J, Gijsen AP, Rooyackers O, van Loon LJ. Co-ingesting milk fat with micellar casein does not affect postprandial protein handling in healthy older men. Clin Nutr 2015.

10. Gorissen SH, Remond D, van Loon LJ. The muscle protein synthetic response to food ingestion. Meat science 2015;109:96-100.

11. Barbe F, Menard O, Le Gouar Y, Buffiere C, Famelart MH, Laroche B, Le Feunteun S, Dupont D, Remond D. The heat treatment and the gelation are strong determinants of the kinetics of milk proteins digestion and of the peripheral availability of amino acids. Food chemistry 2013;136(3-4):1203-12.

12. Pennings B, Groen BB, van Dijk JW, de Lange A, Kiskini A, Kuklinski M, Senden JM, van Loon LJ. Minced beef is more rapidly digested and absorbed than beef steak, resulting in greater postprandial protein retention in older men. Am J Clin Nutr 2013;98(1):121-8.

13. Bax ML, Buffiere C, Hafnaoui N, Gaudichon C, Savary-Auzeloux I, Dardevet D, Sante-Lhoutellier V, Remond D. Effects of meat cooking, and of ingested amount, on protein digestion speed and entry of residual proteins into the colon: a study in minipigs. PLoS One 2013;8(4):e61252.

14. Bax ML, Aubry L, Ferreira C, Daudin JD, Gatellier P, Remond D, Sante-Lhoutellier V. Cooking temperature is a key determinant of in vitro meat protein digestion rate: investigation of underlying mechanisms. J Agric Food Chem 2012;60(10):2569-76.

15. Burd NA, Gorissen SH, van Vliet S, Snijders T, van Loon LJ. Differences in postprandial protein handling after beef compared with milk ingestion during postexercise recovery: a randomized controlled trial. Am J Clin Nutr 2015;102(4):828-36.

16. Boirie Y, Dangin M, Gachon P, Vasson MP, Maubois JL, Beaufrere B. Slow and fast dietary proteins differently modulate postprandial protein accretion. Proc Natl Acad Sci U S A 1997;94(26):14930-5.

17. Dangin M, Boirie Y, Garcia-Rodenas C, Gachon P, Fauquant J, Callier P, Ballevre O, Beaufrere B. The digestion rate of protein is an independent regulating factor of postprandial protein retention. Am J Physiol Endocrinol Metab 2001;280(2):E340-8.

18. Leenders M, van Loon LJ. Leucine as a pharmaconutrient to prevent and treat sarcopenia and type 2 diabetes. Nutrition reviews 2011;69(11):675-89.

19. Tieland M, Borgonjen-Van den Berg KJ, Van Loon LJ, de Groot LC. Dietary Protein Intake in Dutch Elderly People: A Focus on Protein Sources. Nutrients 2015;7(12):9697-706.

20. Phillips SM. Nutrient-rich meat proteins in offsetting age-related muscle loss. Meat science 2012;92(3):174-8.

21. Wilkinson SB, Tarnopolsky MA, Macdonald MJ, Macdonald JR, Armstrong D, Phillips SM. Consumption of fluid skim milk promotes greater muscle protein accretion after resistance exercise than does consumption of an isonitrogenous and isoenergetic soy-protein beverage. Am J Clin Nutr 2007;85(4):1031-40.

22. van Vliet S, Burd NA, van Loon LJ. The Skeletal Muscle Anabolic Response to Plant- versus Animal-Based Protein Consumption. J Nutr 2015.

23. Joint WHOFAOUNUEC. Protein and amino acid requirements in human nutrition. World Health Organization technical report series 2007(935):1-265, back cover.

24. FAOSTAT. Food Balance Sheets. Rome, Italy, 2011.

25. Moore DR, Robinson MJ, Fry JL, Tang JE, Glover El, Wilkinson SB, Prior T, Tarnopolsky MA, Phillips SM. Ingested protein dose response of muscle and albumin protein synthesis after resistance exercise in young men. Am J Clin Nutr 2009;89(1):161-8. 

subsequent muscle protein accretion following graded intakes of whey protein in elderly men. Am J Physiol Endocrinol Metab 2012;302(8):E992-9.

27. Robinson MJ, Burd NA, Breen L, Rerecich T, Yang Y, Hector AJ, Baker SK, Phillips SM. Dose-dependent responses of myofibrillar protein synthesis with beef ingestion are enhanced with resistance exercise in middle-aged men. Appl Physiol Nutr Metab 2013;38(2):120-5.

28. Witard OC, Jackman SR, Breen L, Smith K, Selby A, Tipton KD. Myofibrillar muscle protein synthesis rates subsequent to a meal in response to increasing doses of whey protein at rest and after resistance exercise. Am J Clin Nutr 2014;99(1):86-95.

29. Yang Y, Breen L, Burd NA, Hector AJ, Churchward-Venne TA, Josse AR, Tarnopolsky MA, Phillips SM. Resistance exercise enhances myofibrillar protein synthesis with graded intakes of whey protein in older men. The British journal of nutrition 2012;108(10):1780-8.

30. Reidy PT, Walker DK, Dickinson JM, Gundermann DM, Drummond MJ, Timmerman KL, Cope MB, Mukherjea R, Jennings $\mathrm{K}$, Volpi $\mathrm{E}$, et al. Soy-dairy protein blend and whey protein ingestion after resistance exercise increases amino acid transport and transporter expression in human skeletal muscle. Journal of applied physiology (Bethesda, Md : 1985) 2014;116(11):1353-64.

31. Reidy PT, Walker DK, Dickinson JM, Gundermann DM, Drummond MJ, Timmerman KL, Fry CS, Borack MS, Cope $M B$, Mukherjea $\mathrm{R}$, et al. Protein blend ingestion following resistance exercise promotes human muscle protein synthesis. J Nutr 2013;143(4):410-6.

32. Groen BB, Horstman AM, Hamer HM, de Haan M, van Kranenburg J, Bierau J, Poeze M, Wodzig WK, Rasmussen BB, van Loon LJ. Post-Prandial Protein Handling: You Are What You Just Ate. PLoS One 2015;10(11):e0141582.

33. Tieland $\mathrm{M}$, Borgonjen-Van den Berg KJ, van Loon LJ, de Groot LC. Dietary protein intake in communitydwelling, frail, and institutionalized elderly people: scope for improvement. European journal of nutrition 2012;51(2):173-9.

34. Cuthbertson D, Smith K, Babraj J, Leese G, Waddell T, Atherton P, Wackerhage H, Taylor PM, Rennie MJ. Anabolic signaling deficits underlie amino acid resistance of wasting, aging muscle. Faseb J 2005;19(3):422-4.

35. Bohe J, Low JF, Wolfe RR, Rennie MJ. Latency and duration of stimulation of human muscle protein synthesis during continuous infusion of amino acids. J Physiol 2001;532(Pt 2):575-9.

36. Millward DJ. A protein-stat mechanism for regulation of growth and maintenance of the lean body mass. Nutrition research reviews 1995;8(1):93-120.

37. Churchward-Venne TA, Snijders T, Linkens AM, Hamer HM, van Kranenburg J, van Loon LJ. Ingestion of Casein in a Milk Matrix Modulates Dietary Protein Digestion and Absorption Kinetics but Does Not Modulate Postprandial Muscle Protein Synthesis in Older Men. J Nutr 2015;145(7):1438-45.

38. Drummond MJ, Dreyer HC, Pennings B, Fry CS, Dhanani S, Dillon EL, Sheffield-Moore M, Volpi E, Rasmussen BB. Skeletal muscle protein anabolic response to resistance exercise and essential amino acids is delayed with aging. Journal of applied physiology (Bethesda, Md : 1985) 2008;104(5):1452-61.

39. Bauer JM, Verlaan S, Bautmans I, Brandt K, Donini LM, Maggio M, McMurdo ME, Mets T, Seal C, Wijers SL, et al. Effects of a vitamin $D$ and leucine-enriched whey protein nutritional supplement on measures of sarcopenia in older adults, the PROVIDE study: a randomized, double-blind, placebo-controlled trial. J Am Med Dir Assoc 2015;16(9):740-7.

40. Norton C, Toomey C, McCormack WG, Francis P, Saunders J, Kerin E, Jakeman P. Protein Supplementation at Breakfast and Lunch for 24 Weeks beyond Habitual Intakes Increases Whole-Body Lean Tissue Mass in Healthy Older Adults. J Nutr 2015.

41. Areta JL, Burke LM, Ross ML, Camera DM, West DW, Broad EM, Jeacocke NA, Moore DR, Stellingwerff T, Phillips $\mathrm{SM}$, et al. Timing and distribution of protein ingestion during prolonged recovery from resistance exercise alters myofibrillar protein synthesis. J Physiol 2013;591(Pt 9):2319-31.

42. Kim IY, Schutzler S, Schrader A, Spencer H, Kortebein P, Deutz NE, Wolfe RR, Ferrando AA. Quantity of dietary protein intake, but not pattern of intake, affects net protein balance primarily through differences in protein synthesis in older adults. Am J Physiol Endocrinol Metab 2015;308(1):E21-8.

43. Mamerow MM, Mettler JA, English KL, Casperson SL, Arentson-Lantz E, Sheffield-Moore M, Layman DK, PaddonJones D. Dietary protein distribution positively influences 24 -h muscle protein synthesis in healthy adults. J Nutr 2014;144(6):876-80.

44. Moore DR, Areta J, Coffey VG, Stellingwerff T, Phillips SM, Burke LM, Cleroux M, Godin JP, Hawley JA. Daytime pattern of post-exercise protein intake affects whole-body protein turnover in resistance-trained males. Nutr Metab (Lond) 2012;9(1):91.

45. Groen BB, Res PT, Pennings B, Hertle E, Senden JM, Saris WH, van Loon LJ. Intragastric protein administration stimulates overnight muscle protein synthesis in elderly men. Am J Physiol Endocrinol Metab 2012;302(1):E5260.

46. Res PT, Groen B, Pennings B, Beelen M, Wallis GA, Gijsen AP, Senden JM, LJ VANL. Protein ingestion before sleep improves postexercise overnight recovery. Med Sci Sports Exerc 2012;44(8):1560-9.

47. Snijders T, Res PT, Smeets JS, van Vliet S, van Kranenburg J, Maase K, Kies AK, Verdijk LB, van Loon LJ. Protein Ingestion before Sleep Increases Muscle Mass and Strength Gains during Prolonged Resistance-Type Exercise Training in Healthy Young Men. J Nutr 2015;145(6):1178-84. 
48. Millward DJ. An adaptive metabolic demand model for protein and amino acid requirements. The British journal of nutrition 2003;90(2):249-60.

49. Waterlow JC. Nutritional adaptation in man: general introduction and concepts. Am J Clin Nutr 1990;51(2):25963.

50. Hursel R, Martens EA, Gonnissen HK, Hamer HM, Senden JM, van Loon LJ, Westerterp-Plantenga MS. Prolonged Adaptation to a Low or High Protein Diet Does Not Modulate Basal Muscle Protein Synthesis Rates - A Substudy. PLoS One 2015;10(9):e0137183. 


\section{Summary}

Aging is accompanied by loss of skeletal muscle mass, termed sarcopenia. Loss of skeletal muscle mass results in a decline in muscle strength, which increases the risk of falls and fractures. This will increase hospital and/or nursing home admissions and may reduce the quality of life of older individuals. Physical activity and food intake have been shown to be effective in stimulating muscle protein synthesis. Food intake, and protein ingestion in particular, provides amino acids that serve as precursor for muscle protein synthesis. The stimulation of muscle protein synthesis by protein ingestion is regulated on various levels, including protein digestion and amino acid absorption kinetics, splanchnic amino acid retention, availability of dietary protein-derived amino acids in the circulation, skeletal muscle perfusion and delivery of amino acids to skeletal muscle tissue, amino acid uptake by muscle cells, and intracellular signaling towards myofibrillar protein synthesis. In this dissertation, we investigated dietary factors that modulate postprandial protein handling using stable isotope tracer methodology.

Dietary protein is generally consumed as part of a meal, with carbohydrate and fat being coingested with protein. In chapter $\mathbf{2}$ of this dissertation, we assessed the effects of carbohydrate coingestion with protein on dietary protein digestion and absorption kinetics as well as postprandial muscle protein synthesis rates in young and older men. We observed that carbohydrate coingestion with protein delays dietary protein digestion and absorption, but does not modulate postprandial muscle protein synthesis in healthy young or older men. In addition, we observed that the availability of dietary protein-derived amino acids in the circulation was lower in older when compared with young individuals. Moreover, the postprandial rise in muscle protein synthesis was delayed in older when compared to young men. In chapter $\mathbf{3}$ we investigated protein digestion and absorption kinetics as well as the muscle protein synthetic response to the ingestion of protein with or without fat in older men. Co-ingesting milk fat with micellar casein did not delay or reduce dietary protein digestion and amino acid absorption and did not modulate postprandial myofibrillar protein synthesis rates. The data from these two studies implicate that when adequate protein is consumed, the co-ingestion of large amounts of carbohydrate or fat is not required to maximize the postprandial muscle protein synthetic response in healthy adults. As such, protein-dense clinical nutrition products low in carbohydrate and fat may be preferred in interventional strategies aiming to preserve skeletal muscle mass in conditions in which total energy intake is compromised.

After investigating the individual effects of co-ingesting carbohydrate or fat with protein, we studied two commonly consumed protein-dense foods with different macronutrient composition and texture, i.e. milk and beef, in chapter 4 . We observed more rapid protein digestion and amino acid absorption kinetics following beef versus milk ingestion, which resulted in a greater postprandial rise in plasma leucine concentrations following beef ingestion. However, the postprandial myofibrillar protein synthetic response did not differ between beef and milk ingestion over the entire $5 \mathrm{~h}$ of post-exercise recovery in young men. Interestingly, we observed a greater myofibrillar protein synthetic response after milk when compared with beef ingestion during the early $2 \mathrm{~h}$ stage of the $5 \mathrm{~h}$ postprandial period.

Besides animal-derived protein sources, our diet also provides protein from plant-based protein sources. Plant-based proteins are more cost-effective and sustainable, and may represent an alternative protein source for the stimulation of muscle protein synthesis rates. Chapter $\mathbf{5}$ evaluated the anabolic properties of wheat protein (most predominant source of plant-based 
proteins) when compared with casein and whey protein. Postprandial plasma leucine and essential amino acid concentrations increased to a greater extent after the ingestion of whey protein when compared with casein and wheat protein. The postprandial muscle protein synthetic response to the ingestion of wheat protein was significantly lower when compared with casein. Nonetheless, ingesting a greater amount of wheat protein, matching for the leucine content of whey protein, substantially increased muscle protein synthesis rates from basal. Thus, a greater amount of wheat protein than casein needs to be ingested to effectively stimulate postprandial muscle protein synthesis in older men.

In chapter $\mathbf{6}$ we determined whether habitual protein intake levels influence basal muscle protein synthesis rates, dietary protein digestion and amino acid absorption kinetics, and/or the postprandial muscle protein synthetic response to the ingestion of $25 \mathrm{~g}$ whey protein. We observed no differences in basal muscle protein synthesis rates after two weeks of habituation to a low $(0.7 \mathrm{~g} / \mathrm{kg} / \mathrm{d})$ when compared with a high $(1.5 \mathrm{~g} / \mathrm{kg} / \mathrm{d})$ protein intake. Habituation to a low protein intake reduced splanchnic amino acid retention, allowing more of the dietary proteinderived amino acids to become available in the circulation. This greater dietary protein-derived amino acid availability after habituation to low protein intake may have been responsible for maintaining the postprandial muscle protein synthetic response to protein intake. No differences were observed in the postprandial muscle protein synthetic response to the ingestion of $25 \mathrm{~g}$ whey protein after habituation to a low compared with a high protein intake in healthy adults.

The final chapter elaborated on the primary findings described in this dissertation and identified a number of topics that need to be addressed in the future. This dissertation shows that a combination of various factors modulate the postprandial muscle protein synthetic response to protein ingestion. Optimizing protein intake to maximize postprandial muscle protein synthesis rates following each meal may contribute to the preservation of skeletal muscle mass with aging or in various clinical settings in more compromised patient populations. 


\section{Samenvatting}

Veroudering gaat gepaard met verlies van spiermassa, ook wel sarcopenie genoemd. Verlies van spiermassa leidt tot een afname van de spierkracht, waardoor de kans op vallen en botbreuken wordt verhoogd. Dit zorgt voor een toename in ziekenhuis- en/of verpleeghuisopnames en kan de levenskwaliteit van ouderen sterk verminderen. Fysieke activiteit en gezonde voeding blijken beiden effectief te zijn in het stimuleren van spieropbouw en daarmee het handhaven van spiermassa en functionele capaciteit. Eiwitten in de voeding voorzien het lichaam van aminozuren die dienen als bouwstenen voor de spieren. Het stimuleren van spiereiwitsynthese door eiwitinname wordt gereguleerd door verschillende processen, waaronder eiwitvertering en aminozuuropname in de darm, gebruik van aminozuren door de darm en lever, beschikbaarheid van aminozuren in de bloedsomloop, doorbloeding van de skeletspieren en transport van aminozuren naar het skeletspierweefsel, opname van aminozuren door spiercellen en intracellulaire signalering die spiereiwitsynthese activeert. In dit proefschrift hebben we onderzoek gedaan naar factoren in de voeding die eiwitvertering en postprandiale spiereiwitsynthese beïnvloeden. Hierbij hebben we gebruik gemaakt van stabiele isotopen tracer methodologie.

Eiwitten worden over het algemeen ingenomen als onderdeel van een maaltijd waarbij ook andere macronutriënten zoals koolhydraten en vetten worden ingenomen. In hoofdstuk 2 van dit proefschrift hebben we onderzoek gedaan naar de effecten van inname van koolhydraten in combinatie met eiwit op de eiwitvertering en postprandiale spiereiwitsynthese in jonge en oudere mannen. In dit hoofdstuk laten we zien dat de inname van koolhydraten in combinatie met eiwit de vertering van het eiwit vertraagt, maar dit beperkt de postprandiale spiereiwitsynthese niet in jonge en oudere mannen. Verder laten we zien dat de postprandiale beschikbaarheid van aminozuren in de bloedsomloop lager is bij oudere in vergelijking met jongere mannen en dat de daarop volgende postprandiale stijging in spiereiwitsynthese is vertraagd in oudere mannen vergeleken met jonge mannen. In hoofdstuk $\mathbf{3}$ hebben we onderzoek gedaan naar eiwitvertering en postprandiale spiereiwitsynthese na inname van eiwit met of zonder vet bij oudere mannen. Co-ingestie van melkvet met eiwit vertraagt of beperkt de eiwitvertering niet en heeft geen effect op de postprandiale spiereiwitsynthese. De resultaten van de onderzoeken in hoofdstukken 2 en 3 impliceren dat bij een voldoende eiwitinname geen (grote hoeveelheden) koolhydraten of vetten nodig zijn om de postprandiale spiereiwitsynthese maximaal te stimuleren. Eiwitrijke klinische voedingsproducten met weinig of geen additionele koolhydraten of vetten kunnen een bijdrage leveren in interventies met als doel spiermassaverlies te voorkomen of te verminderen in condities waarbij de totale energie-inname is beperkt.

Als vervolg op de onderzoeken naar de individuele effecten van koolhydraat of vet co-ingestie op de eiwitvertering en spiereiwitsynthese, hebben we in hoofdstuk $\mathbf{4}$ de twee meest geconsumeerde eiwitrijke voedingsmiddelen (melk en rundvlees), met verschillende macronutriëntsamenstelling en textuur, bestudeerd. We laten zien dat de eiwitvertering en aminozuuropname sneller verloopt na inname van rundvlees in vergelijking met melk, waardoor we na inname van rundvlees een sterkere stijging zien in de leucineconcentraties in het bloed. Toch blijkt de postprandiale spiereiwitsynthese niet te verschillen na inname van rundvlees in vergelijking met melk in jongere mannen tijdens het herstel na een krachttrainingssessie. Tegen onze verwachting in blijkt de postprandiale spiereiwitsynthese hoger gedurende de eerste 2 uur na consumptie van melk in plaats van rundvlees. 
Naast dierlijke eiwitbronnen bevat onze voeding ook eiwitten uit plantaardige eiwitbronnen. Plantaardige eiwitten zijn goedkoper en duurzamer in vergelijking met dierlijke eiwitten, en kunnen daarom mogelijk dienen als alternatieve eiwitbron voor het stimuleren van spiereiwitsynthese. In hoofdstuk 5 hebben we onderzoek gedaan naar de anabole eigenschappen van tarwe-eiwit (één van de meest voorkomende plantaardige eiwitten in onze voeding) in vergelijking met caseïne en wei-eiwit (de twee melkeiwitten). De resultaten van dit onderzoek tonen aan dat de concentraties van leucine en essentiële aminozuren in het bloed sterker toenemen na inname van wei-eiwit in vergelijking met eenzelfde hoeveelheid caseïne of tarwe-eiwit. De postprandiale spiereiwitsynthese na inname van tarwe-eiwit is significant lager dan na inname van caseïne. Echter, inname van een grotere hoeveelheid tarwe-eiwit, waarbij wordt gecompenseerd voor het verschil in leucinegehalte van wei-eiwit, leidt wel tot een forse stijging in de spiereiwitsynthese. Dit betekent dat een grotere hoeveelheid tarwe-eiwit is vereist om eenzelfde stijging in spiereiwitsynthese te bereiken in oudere mannen als na inname van caseïne.

In hoofdstuk 6 hebben we onderzocht of de hoeveelheid eiwit die dagelijks wordt ingenomen een effect heeft op de basale spiereiwitsynthese, eiwitvertering en aminozuuropname en de postprandiale spiereiwitsynthese na inname van $25 \mathrm{~g}$ wei-eiwit. Dit onderzoek toont aan dat er geen verschil is in basale spiereiwitsynthese na het volgen van een dieet met een lage $(0,7 \mathrm{~g} / \mathrm{kg} / \mathrm{d})$ versus een hoge $(1,5 \mathrm{~g} / \mathrm{kg} / \mathrm{d})$ eiwitinname gedurende 2 weken voorafgaand aan de metingen. Het verbruik van aminozuren door de darm en lever blijkt gereduceerd na het laag-eiwitdieet, waardoor meer aminozuren beschikbaar komen in de bloedsomloop. De postprandiale spiereiwitsynthese na inname van $25 \mathrm{~g}$ wei-eiwit is niet verschillend na het volgen van een dieet met een lage of hoge eiwitinname.

Het laatste hoofdstuk gaat in op de primaire bevindingen beschreven in dit proefschrift en identificeert een aantal onderwerpen die in de toekomst zouden moeten worden onderzocht. Dit proefschrift laat zien dat een combinatie van diverse factoren de spiereiwitsynthese na eiwitinname bepaalt. Het optimaliseren van eiwitinname en daarbij zorgen voor een maximale stimulatie van spiereiwitsynthese na elke maaltijd kan mogelijk bijdragen aan het behoud van spiermassa bij veroudering of bij gecompromitteerde patiëntpopulaties, zoals patiënten in een verpleegkliniek of ziekenhuis. 


\section{Valorization}

In almost every country, the proportion of people aged $60 \mathrm{y}$ and over is increasing rapidly. Between 2015 and 2050, the proportion of the world's population over $60 \mathrm{y}$ will nearly double from 12 to $22 \%$. The number of people aged $80 \mathrm{y}$ and older is expected to rise from 125 million in 2015 to 434 million by 2050 (1). In the Netherlands, the total population will continue to grow over the next few decades to 18.1 million in 2060. The increase in population size is, at least partly, due to the increasing longevity. The current life expectancy is on average 80 and $83 \mathrm{y}$ for boys and girls born in 2014, respectively. This life expectancy is predicted to increase by 7 years by 2060 . The increasing life expectancy will contribute to the increase in the number of elderly individuals. The number of people aged over 65 years is expected to increase from 3.0 million in 2014 to 4.7 million in 2060. The number of people aged 80 years and older is expected to increase from 0.7 to 2 million in 2060 (2). The aging of the population can be seen as a success for public health policies and for socioeconomic development, but it also challenges society to improve health and functional capacity of older people and stimulate their social participation (1). Aging is accompanied by a decline in skeletal muscle mass, also known as sarcopenia. Loss of skeletal muscle mass may lead to a reduction in muscle strength and physical function, which increases the risk of falls and fractures. This could ultimately result in the loss of independence and an increase in nursing home admissions. Developing effective interventions to prevent or delay the onset of sarcopenia may reduce healthcare costs and improve the quality of life of older individuals.

In line with previous work, this dissertation provides further evidence that dietary protein intake directly stimulates muscle protein synthesis. In older individuals, the muscle protein synthetic response to protein intake is reduced (3), which may, at least partly, explain the age-related loss of skeletal muscle mass. The work presented in this dissertation used a novel stable isotope tracer methodology to assess certain aspects of postprandial protein handling in young and older individuals following various dietary interventions. We combined primed continuous intravenous infusions of stable isotope-labeled amino acid tracers with the ingestion of intrinsically labeled protein to assess dietary protein digestion and amino acid absorption kinetics, splanchnic amino acid retention, availability of dietary protein-derived amino acids in the circulation, basal and postprandial muscle protein synthesis rates, as well as the incorporation of dietary protein-derived amino acids into myofibrillar protein in vivo in humans (4). We demonstrate that dietary protein digestion and absorption may be impaired in the older population and that the postprandial increase in muscle protein synthesis is delayed in healthy older when compared with young men. These differences in postprandial protein handling may play important roles in the etiology of sarcopenia. We speculate that older people require more protein and/or higher quality protein to maximize postprandial muscle protein synthesis rates. Therefore, we studied dietary factors that may modulate the anabolic response to meal ingestion. Specifically, we investigated the role of carbohydrate and fat co-ingestion with protein, the impact of various dietary protein sources, and the relevance of habituation to a certain level of dietary protein intake. A better understanding of the various dietary factors that modulate the anabolic response to food intake enables us to develop dietary intervention strategies that maximize the postprandial muscle protein synthetic response and thereby compensate for the anabolic resistance with aging. The findings described in this dissertation provide the basis for defining alternative dietary intervention strategies that will help to preserve skeletal muscle mass in the older population. 
Our diet provides protein from both animal-derived as well as plant-based protein sources. Though animal-derived proteins (e.g. dairy protein) are very potent in stimulating muscle protein synthesis, plant-based proteins are more cost-effective and sustainable, and may represent an alternative protein source for the stimulation of muscle protein synthesis rates. In this dissertation we demonstrate that the ingestion of wheat protein (one of the most predominant plant-based proteins in our diet) stimulates muscle protein synthesis provided that a relatively high dose of protein is consumed. The lower muscle protein synthetic response to lower doses of wheat protein might be due to a suboptimal amino acid profile of wheat protein, with a low lysine and leucine content in particular. We speculate that the combination of wheat protein and dairy protein may result in a protein blend with greater anabolic properties by providing a more preferred spectrum of essential and non-essential amino acids. These protein blends can contribute to the development of more sustainable and cost-effective nutritional strategies that support muscle mass preservation in people living in less privileged regions of the world.

Despite the necessity of studying the acute effects of various dietary factors on postprandial protein handling in controlled laboratory conditions, these findings need to be confirmed in more practical or applied settings. Recent advances in the field of muscle physiology introduced the use of deuterium-labeled water to assess muscle protein synthesis over days to weeks under freeliving conditions. Studies using this methodology will be next to evaluate whether dietary strategies that apply the current findings can help to preserve muscle mass in the older population. It can be challenging to successfully implement such dietary intervention strategies into practice. To achieve such knowledge translation, a more interdisciplinary approach between scientists in the field of human nutrition and physiology, behavioral scientists, clinicians, and health care professionals should be pursued. The findings from 'small' experimental studies as presented in this dissertation need to be translated into larger cohort studies to evaluate the feasibility, applicability, and efficacy of changing food intake strategies to support muscle mass preservation in daily life. The research described in this dissertation defines the impact of a few dietary components that modulate the postprandial muscle protein synthetic response to meal ingestion. These findings can directly be applied to change food and food products as well as design more effective clinical nutrition products that should be part of dietary interventions to preserve muscle mass and prevent sarcopenia in both health and disease.

Consequently, the presented data provide many leads and targets for product development and innovations in the nutrition industry. Nutrition companies aim to improve current product formulations and/or develop new products or concepts to support healthy aging. Results from this dissertation provide clear insights on macronutrient composition and protein sources that need to be applied in the development or improvement of novel product formulations to maximally stimulate muscle protein synthesis and, as such, assist in the various strategies to combat the loss of skeletal muscle mass with aging. For example, we show that co-ingesting carbohydrate or fat with protein does not further improve the postprandial muscle protein synthetic response to protein intake. Clinical nutrition products generally contain a combination of all three macronutrients. We suggest that more protein-dense clinical nutrition products with lower amounts of carbohydrate and fat are preferred in interventional strategies aiming to preserve skeletal muscle mass where protein malnutrition is the main concern. Preservation of skeletal muscle mass is of major importance from a societal perspective regarding the quality of life of the individual, but also from an economic perspective regarding the enormous health care costs associated with sarcopenia. Besides the aging population, the results from this dissertation may be translated to other clinical conditions where progressive skeletal muscle mass loss is observed. 
Cancer cachexia, chronic obstructive pulmonary disease (COPD), renal insufficiency, cardiovascular disease, and diabetes generally lead to a condition that resembles a state of accelerated aging. As strength and muscle loss seem to be accelerated in these more clinically compromised populations, it is evident that nutritional strategies should focus both on the prevention as well as treatment of muscle loss.

As individual scientists, we all work on just one piece of the puzzle. However, combining the knowledge gained from multiple studies conducted by different laboratories over the world within various fields of research will allow us to define (more) effective and sustainable dietary and physical activity intervention strategies to combat the age-related loss of skeletal muscle mass and strength and, as such, support healthy aging.

\section{ReFERENCES}

1. WHO. World report on ageing and health. 2015.

2. CBS. Centraal Bureau voor de Statistiek: 18,1 miljoen inwoners in 2060. Persbericht PB14-085 2014.

3. Wall BT, Gorissen SH, Pennings B, Koopman R, Groen BB, Verdijk LB, van Loon LJ. Aging Is Accompanied by a Blunted Muscle Protein Synthetic Response to Protein Ingestion. PLoS One 2015;10(11):e0140903.

4. Burd NA, Cermak NM, Kouw IW, Gorissen SH, Gijsen AP, van Loon LJ. The use of doubly labeled milk protein to measure postprandial muscle protein synthesis rates in vivo in humans. Journal of applied physiology (Bethesda, Md : 1985) 2014;117(11):1363-70. 


\section{Dankwoord}

Promoveren doe je natuurlijk niet alleen en daarom wil ik graag iedereen bedanken die, op welke wijze dan ook, heeft bijgedragen aan mijn wetenschappelijke ontwikkeling en het tot stand komen van dit proefschrift. Zonder de hulp van velen was dit nooit zo een succes geworden. Een aantal mensen wil ik in het bijzonder bedanken.

Ten eerste natuurlijk mijn promotor, Luc. Je hebt me de afgelopen jaren alle mogelijkheden gegeven die nodig waren om mij klaar te stomen voor een wetenschappelijke carrière. Ik heb verschillende congressen bezocht, buitenland ervaring opgedaan en zelfs een keynote lecture mogen geven op een internationaal congres. Ik heb een vijftal studies opgezet en uitgevoerd waarvan ik zeer veel heb geleerd op verschillende fronten. Misschien wel het belangrijkste binnen de wetenschap is het delen van kennis via presentaties of wetenschappelijke artikelen. Jouw vaardigheden op dit vlak zijn ongekend en ik ben enorm dankbaar voor de wijze waarop jij me dit met veel geduld hebt geleerd.

Nick, during the first 2 years of my PhD, you were my daily supervisor who taught me a lot on tracer methodology and muscle protein metabolism, which I am really grateful for. It was always good fun having you around during our trips to Wageningen for the glowing cow experiment and TIFN meetings, all the trials we have run together, sorting all those plasma samples at the end of a trial, prepping muscle biopsies in the lab, and of course the beer tastings at the Frape. Thank you very much for the great time and all your help with my trials and papers.

The members of the Assessment Committee, Prof. dr. Ellen Blaak, Prof. dr. Yves Boirie, Prof. dr. Edith Feskens, Dr. Kaatje Lenaerts, and Prof. dr. Steven Olde Damink, thank you for thoroughly reading and reviewing this dissertation and for participating in the Supervisory Committee.

The TIFN partners, Jan Steijns, Sjors Verlaan, Yvette Luiking, Kathy Greaves, Arie Kies, Lisette de Groot, thank you very much for your invaluable insight and advice regarding study design, data analysis, and data interpretation.

Astrid Haegens, ondanks dat je niet echt betrokken bent geweest bij mijn promotieproject, wil ik je toch bedanken. Ruim 5 jaar geleden, toen ik stage liep in Vermont en ik niet wist welke richting ik op wilde, heb jij me geadviseerd om te solliciteren op een project van Luc van Loon. Ik kende Luc toen nog niet en had absoluut geen ervaring met humaan onderzoek. Ik ben echter heel blij dat ik deze keuze heb gemaakt en ben vooral heel dankbaar voor jouw advies en hulp bij het krijgen van deze promotieplek. 
Henrike, jij was de postdoc in het lab die mij leerde humane trials uit te voeren. Voordat ik begon had jij er al voor gezorgd dat we goedkeuring hadden van de medisch ethische commissie, zodat we meteen konden beginnen met de praktische uitvoering van mijn eerste studie. Ik kan me nog goed onze eerste screening herinneren, toen we met 4 man sterk één nogal zenuwachtige proefpersoon hebben geïncludeerd (terwijl ik nu 4 proefpersonen in mijn eentje screen). Ook de eerste testdagen vond ik best spannend, maar dankzij jouw goede training waren deze testdagen altijd tot in de puntjes voorbereid en gecontroleerd en kon ik binnen enkele maanden, voordat jij met zwangerschapsverlof ging, zelfstandig deze testdagen uitvoeren. Hartelijk dank voor al jouw hulp!

Bart, ook van jou heb ik veel geleerd wat betreft de uitvoering van humane trials. Als biopteur heb je heel wat biopten afgenomen, met name in mijn eerste studie. Na afloop van de testdag kwamen we altijd even bij elkaar om de testdag te evalueren. Ik wil je bedanken voor deze leerzame discussies en de manier waarop jij me leerde om de testdagen nog beter en efficiënter te laten verlopen.

De praktische uitvoering van de vele onderzoeken is natuurlijk een hele klus en dit was niet mogelijk geweest zonder de hulp van stagiaires en onderzoeksassistenten. Kirsten, Maxime, Julie, Henning en Rinske, ik wil jullie van harte bedanken voor al jullie inzet tijdens de screenings, testdagen, de voorbereidingen hiervan en de datacontrole.

Annemie, niemand heeft meer ervaring met tracer-analyses dan jij! Jij hebt er altijd voor gezorgd dat het SIRC perfect in orde is voor accurate analyse van mijn plasmasamples en spierbiopten. We zijn zelfs een keer naar Zweden gegaan, waar jij onze methode hebt opgezet in het lab van Olav Rooyackers, zodat ik daar één van mijn studies kon analyseren. Ik wil je graag bedanken voor al je hulp bij deze analyses. Natuurlijk wil ik ook Janneau, Joy en Joan bedanken voor al hun hulp bij het opwerken van honderden samples en het integreren van duizenden pieken.

Joey, ik had mijn koffie amper op of jij stond alweer in mijn kantoor voor een nieuw bakkie en een kletspraatje op de gang. Jij zorgde altijd voor gezelligheid en teamspirit binnen de groep en mede dankzij jouw aanwezigheid waren borrels en groepsactiviteiten altijd geslaagd.

Imre, wij zijn in dezelfde periode gestart, ik als promovendus en jij als master-student. We hebben samen veel testdagen uitgevoerd en je stond altijd klaar om te helpen of simpelweg een praatje te maken met de proefpersonen. Na afloop van de testdagen hebben we regelmatig samen gegeten of gingen we op stap voor een biermenuutje bij de Falstaff. Jij wist me er altijd van te overtuigen nog even één biertje te doen bij De Twee Heeren (en ja, misschien zelfs nog wel een dansje te wagen). Je was dus niet alleen een zeer gewaarde collega, maar je bent ook een goede vriendin geworden. Ik ben dan ook 
echt heel dankbaar dat jij, samen met Joey, mijn paranimf wil zijn. Mede door jullie enthousiasme ben ik ervan overtuigd dat dit een onvergetelijke dag gaat worden.

Alle andere collega's van de M3 onderzoeksgroep en de vakgroepengemeenschap Humane Biologie en Bewegingswetenschappen, waaronder Lex, Naomi, Ben, Astrid, Tyler, Marlou, Irene Fleur, Tim, Jan-Willem, Andy, Evelien, Anne, Cleo, Desiree, en Jos, wil ik uiteraard ook van harte bedanken. Naast jullie wetenschappelijke of administratieve hulp, hebben jullie er ook voor gezorgd dat ik het de afgelopen jaren enorm naar mijn zin heb gehad.

Pap, mam en Sylvia, jullie hebben me altijd ondersteund om dit einddoel te bereiken. Een wetenschappelijke carrière is niet altijd eenvoudig te combineren met het privé- en fanfareleven, dat bij ons redelijk nauw verweven is. Mijn beslissing om tijdelijk naar het buitenland te gaan, niet alleen voor mijn stage in Vermont maar ook nu als postdoc in Canada, is voor jullie (en vooral voor mam) niet makkelijk. Toch steunen jullie me hierin en staan jullie altijd voor me klaar waarvoor ik jullie enorm wil bedanken!

Opa, helaas hebben we enkele weken geleden afscheid van u moeten nemen en kunt $u$ niet meer aanwezig zijn bij mijn promotie. Tijdens de laatste paar maanden van uw leven hebt $u$ veel spiermassa verloren, waardoor $u$ niet meer de kracht had om dagelijkse activiteiten uit te voeren en uw kwaliteit van leven ineens sterk achteruit ging. $U$ hebt me laten inzien hoe belangrijk dit onderzoek is, maar ook (mogelijke mede door uw eigenzinnigheid) hoe lastig het soms kan zijn om de kennis te implementeren in de praktijk.

Kirsten, ik denk dat ik jou het meest dankbaar ben voor het feit dat je ooit "ja" hebt gezegd op de vraag of je spierbiopten zou willen nemen in mijn studie. Zo leerde ik jou steeds beter kennen en zijn we nu al enkele jaren samen. In die tijd heb je veel voor me betekend en stond je altijd voor me klaar om me te helpen of als het even tegen zat. Je hebt zelfs nog een keer spierbiopten bij mij persoonlijk afgenomen. Ik weet niet precies hoe dat eraan toeging, maar volgens mij heb je genoeg spierweefsel eruit gehaald zodat ik een goede bijdrage heb kunnen leveren aan de wetenschap. Nu moeten we elkaar even missen en geef je me de ruimte om ervaring op te doen als postdoc in Canada. Ik wilde dit altijd al heel graag en ik ben blij dat je mij hierin steunt. Bedankt voor alles! 


\section{Curriculum Vitae}

Stefan Gorissen was born on May 24, 1988 in Geleen, the Netherlands. In 2005, he completed Higher General Secondary Education (HAVO) at Graaf Huyn College in Geleen. Afterwards, he started a Bachelor of Applied Science in Biology and Medical Laboratory Research (HLO) at Zuyd University in Heerlen, the Netherlands. During his Bachelor's, he performed internships at the Department of Anatomy \& Embryology and the Department of Respiratory Medicine at Maastricht University in Maastricht, the Netherlands. He completed his Bachelor's degree in 2009 under supervision of Dr. Astrid Haegens investigating the role of NF-KB activation and muscle protein degradation by the Ubiquitin-Proteasome Pathway in inflammation-induced diaphragm muscle atrophy. After obtaining his Bachelor's degree, Stefan started a Master of Science in Clinical Molecular Sciences at Maastricht University. During his first year, he completed an internship with Professor Stefan Schulte-Merker at the Hubrecht Institute in Utrecht, the Netherlands. During his second year, he conducted a project under supervision of Professor Albert van der Vliet in Burlington at the University of Vermont, USA. He completed his Master's project on the role of the NADPH oxidase homolog dual oxidase 1 (Doux1) in asthma and graduated in July 2011.

In August 2011, Stefan started his PhD at the Department of Human Biology at Maastricht University within NUTRIM School of Nutrition and Translational Research in Metabolism under the supervision of Professor Luc van Loon and Dr. Nicholas Burd. Stefan conducted a TI Food and Nutrition project titled "Muscle mass preservation" that focused on the impact of macronutrient co-ingestion on postprandial muscle protein accretion. In addition, he completed a project funded by Tereos entitled "Postprandial muscle protein synthesis rates following wheat protein ingestion in vivo in humans". During his PhD, Stefan attended several national and international conferences and was awarded the Young Investigator Award at the 18th annual European College of Sport Sciences congress in Barcelona, Spain. Moreover, he received the TI Food and Nutrition Publication Prize 2014 in the category Nutrition and Health with the publication "Carbohydrate co-ingestion delays dietary protein digestion and absorption but does not modulate postprandial muscle protein accretion". In November and December 2014, he visited the laboratory of Professor Olav Rooyackers at the Department of Anesthesia and Intensive Care at Karolinska University Hospital in Huddinge, Sweden to undertake further research training, specifically the use of GC-MS for the determination of stable isotope tracer enrichments. During his PhD, Stefan successfully supervised several Bachelor's and Master's students. Furthermore, Stefan was a member of the executive board of the Department of Human Biology, a member of the NUTRIM PhD Students Council, and he was involved in the organization of three editions of the Annual NUTRIM conference.

Currently, Stefan Gorissen is working as a Postdoctoral researcher at the Department of Kinesiology at McMaster University in Hamilton, Ontario, Canada under supervision of Professor Stuart Phillips, where he continues his work in the field of nutrition and aging. 


\section{LIST OF PUBLICATIONS}

1. Gorissen SH, Burd NA, Kramer IF, van Kranenburg J, Gijsen AP, Rooyackers O, van Loon LJ. Co-ingesting milk fat with micellar casein does not affect postprandial protein handling in healthy older men. Clin Nutr 2015. (IF: 4.5)

2. Wall BT, Gorissen SH, Pennings B, Koopman R, Groen BB, Verdijk LB, van Loon LJ. Aging Is Accompanied by a Blunted Muscle Protein Synthetic Response to Protein Ingestion. PLoS One 2015;10(11). (IF: 3.2)

3. Gorissen SH, Burd NA, van Vliet S, Snijders T, van Loon LJ. Differences in postprandial protein handling after beef compared with milk ingestion during postexercise recovery: a randomized controlled trial. Am J Clin Nutr 2015;102(4):828-36. (IF: 6.8)

4. Kouw IW, Gorissen SH, Burd NA, Cermak NM, Gijsen AP, van Kranenburg J, van Loon LJ. Postprandial Protein Handling Is Not Impaired in Type 2 Diabetes Patients When Compared With Normoglycemic Controls. J Clin Endocrinol Metab 2015;100(8):3103-11. (IF: 6.2)

5. Gorissen SH, Remond D, van Loon LJ. The muscle protein synthetic response to food ingestion. Meat science 2015;109:96-100. (IF: 2.6)

6. Burd NA, Cermak NM, Kouw IW, Gorissen SH, Gijsen AP, van Loon LJ. The use of doubly labeled milk protein to measure postprandial muscle protein synthesis rates in vivo in humans. J Appl Physiol 2014;117(11):1363-70. (IF: 3.1)

7. Gorissen SH, Burd NA, Hamer HM, Gijsen AP, Groen BB, van Loon L. Carbohydrate coingestion delays dietary protein digestion and absorption but does not modulate postprandial muscle protein accretion. J Clin Endocrinol Metab 2014;99(6):2250-8. (IF: 6.2) (TI Food and Nutrition Publication Prize 2014 Nutrition and Health)

8. Burd NA, Gorissen SH, van Loon LJ. Anabolic resistance of muscle protein synthesis with aging. Exerc Sport Sci Rev 2013;41(3):169-73. (IF: 4.3)

9. Kouw IW, Tieland M, Gorissen SH. A step towards underpinning the molecular signalling events regulating muscle protein loss in critically ill patients. J Physiol 2011;589(Pt 24):5925-6. (IF: 5.0)

10. Gorissen SH, Hristova M, Habibovic A, Sipsey LM, Spiess PC, Janssen-Heininger YM, van der Vliet A. Dual oxidase-1 is required for airway epithelial cell migration and bronchiolar reepithelialization after injury. Am J Respir Cell Mol Biol 2013;48(3):337-45. (IF: 4.0)

11. Haegens A, Schols AM, Gorissen SH, van Essen AL, Snepvangers F, Gray DA, Shoelson SE, Langen RC. NF-kappaB activation and polyubiquitin conjugation are required for pulmonary inflammation-induced diaphragm atrophy. Am J Physiol Lung Cell Mol Physiol 2012;302(1):L103-10. (IF: 4.1) 


\section{SUBMITTED FOR PEER-PREVIEW}

- Gorissen SH, Horstman AM, Franssen R, Kouw IW, Wall BT, Burd NA, de Groot LC, van Loon LJ. Habituation to a low or high protein intake does not modulate basal or postprandial muscle protein synthesis rates: a randomized trial. Submitted at Am J Clin Nutr in 2016

- Gorissen SH, Horstman AM, Franssen R, Crombag JJ, Langer H, Bierau J, Respondek F, van Loon LJ. The anabolic properties of wheat protein hydrolysate compared to casein and whey: a randomized trial. Submitted at J Nutr in 2016

\section{Oral pRESENTATIONS}

- Gorissen SH, Respondek F, Franssen R, Crombag JJ, Langer H, Horstman AM, van Loon LJ. The anabolic properties of wheat protein hydrolysate compared to casein and whey. 12th FENS European Nutrition conference, Berlin, Germany, 2015

- Gorissen SH, Horstman AM, Franssen R, Kouw IW, Kramer IF, Wall BT, Burd NA, de Groot LC, van Loon LJ. The impact of habitual protein intake on dietary protein digestion and absorption kinetics and postprandial muscle protein synthesis rates in older males. 37th ESPEN Congress, Lisbon, Portugal, 2015

- Gorissen SH, Rémond D, van Loon LJ. The muscle protein synthetic response to food ingestion. 61st International Congress of Meat Science \& Technology, Clermont-Ferrand, France, 2015 (Invited keynote lecture)

- $\quad$ Gorissen SH, Burd, NA, Hamer HM, Gijsen AP, van Loon LJ. Carbohydrate co-ingestion with protein delays digestion and absorption but does not modulate postprandial muscle protein accretion. 18th annual Congress of the European College of Sport Science 2013, Barcelona, Spain (Young Investigator Award)

- Gorissen SH, Burd NA, Hamer HM, Gijsen AP, van Loon LJ. Carbohydrate co-ingestion with protein delays dietary protein digestion and absorption but does not modulate postprandial muscle protein accretion. Experimental Biology 2013, Boston, Massachusetts, USA

\section{POSTER PRESENTATIONS}

- Gorissen SH, Respondek F, Franssen R, Crombag JJ, Langer H, Horstman AM, van Loon LJ. The anabolic properties of wheat protein hydrolysate compared to casein and whey. 37th ESPEN Congress, Lisbon, Portugal, 2015 (Outstanding abstract) 
- Gorissen SH, Burd NA, Kramer IF, van Kranenburg J, Gijsen AP, van Loon LJ. Fat co-ingestion does not impair postprandial protein digestion and absorption kinetics or whole-body net protein balance in elderly males. 36th ESPEN Congress, Geneva, Switzerland, 2014 (Outstanding abstract)

- $\quad$ Gorissen SH, Burd NA, van Kranenburg J, Snijders T, van Loon LJ. Beef and milk do not differ in their capacity to stimulate post-exercise myofibrillar protein synthesis in young males. 19th annual Congress of the European College of Sport Science 2014, Amsterdam, The Netherlands

\section{AWARDS}

- $\quad$ TI Food and Nutrition Publication Prize 2014 Nutrition and Health with the publication "Carbohydrate co-ingestion delays dietary protein digestion and absorption but does not modulate postprandial muscle protein accretion"

- Young Investigator Award at the 18th annual European College of Sport Sciences congress in Barcelona, Spain 


\section{Financial support}

Financial support by the following companies for the publication of this dissertation is gratefully acknowledged.
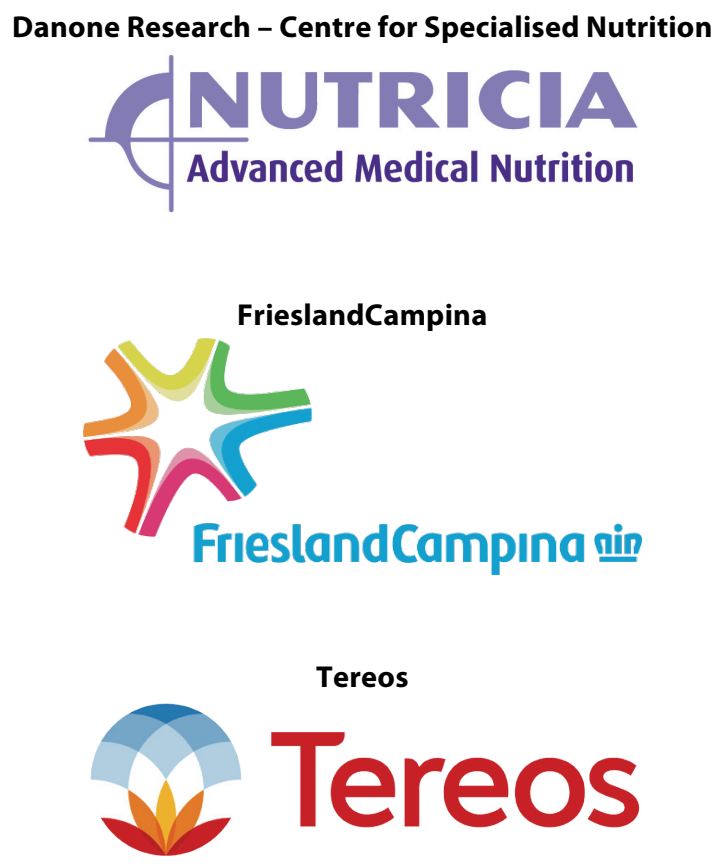

Medische Laboratoria Dr. Stein \& Collegae

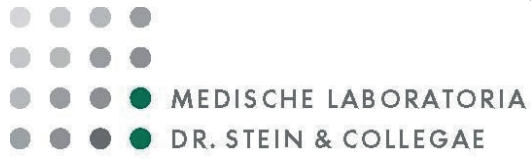




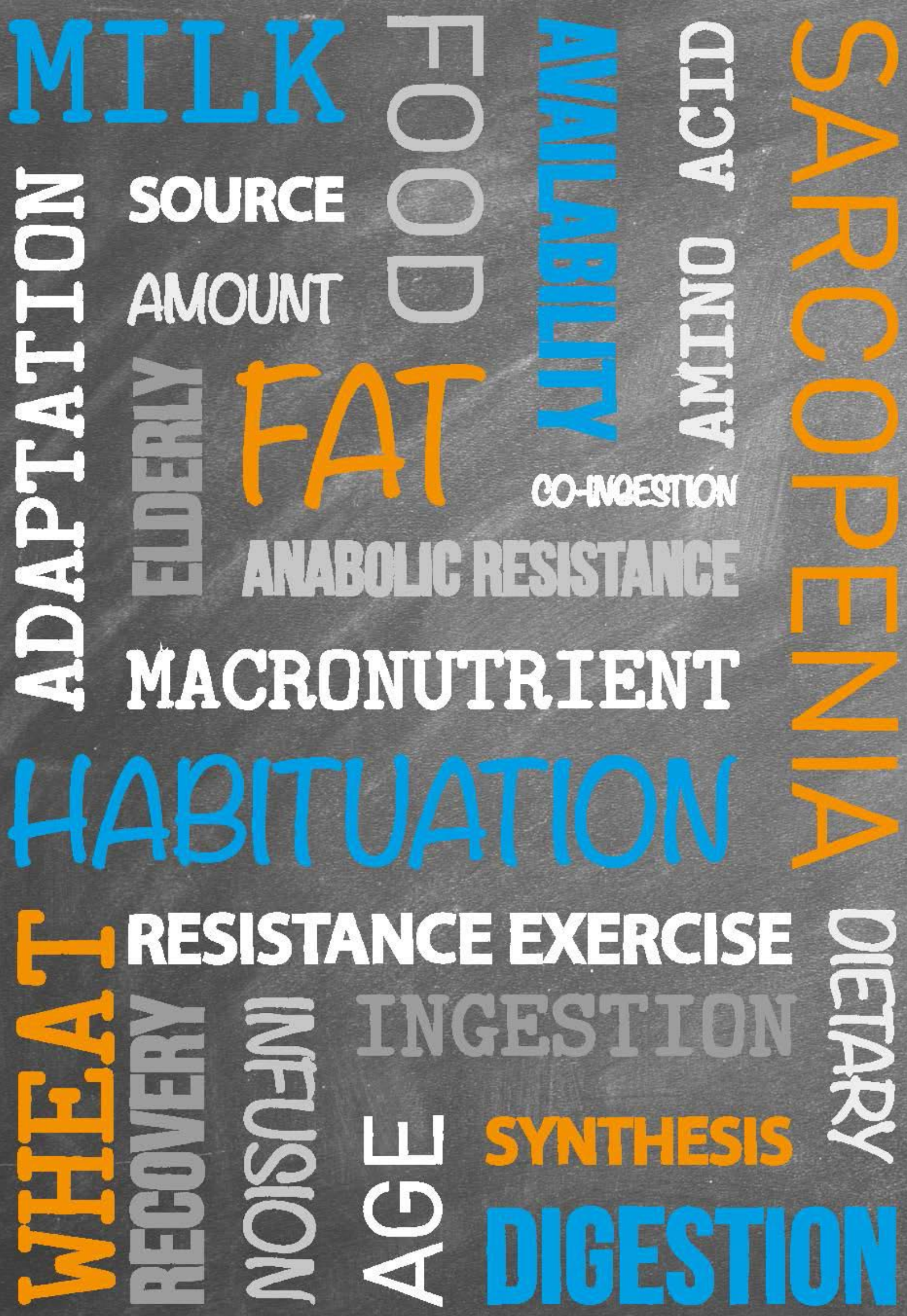